\title{
PROPOSTA METOdOLÓGICA PARA AVALIAÇÃo ERGONÔMICA DO AMBIENTE URBANO: A INSERCÇ̃̃O DA ERGONOMIA NO AMBIENTE CONSTRUÍDO
}



Universidade de São Paulo

Faculdade de Arquitetura e Urbanismo

\title{
PROPOSTA METODOLÓGICA PARA AVALIAÇÃO ERGONÔMICA DO AMBIENTE URBANO: A INSERÇÃO DA ERGONOMIA NO AMBIENTE CONSTRUÍDO
}

\author{
Roberta Consentino Kronka Mülfarth
}

Tese apresentada como parte dos requisitos do concurso para obtenção do título de Livre-Docência do Departamento de Tecnologia da Faculdade de Arquitetura e Urbanismo da Universidade de São Paulo FAUUSP (Edital ATAc 086/2016). 
Dedico este trabalho ao Guilherme Kronka Mülfarth por toda sua alegria que em muitos momentos me auxiliou... 


\section{0 pedestre é afinal, uma espécie que tende a desaparecer, se é que já não desapareceu de todo... Com licença, queremos passar.}




\section{RESUMO}

Este trabalho tem como objetivo principal apresentar proposta de método de avaliação ergonômica para o ambiente urbano, no qual a ergonomia possui um caráter de integração com o conforto ambiental. A pesquisa parte da hipótese que a ergonomia pode ser entendida de forma mais abrangente e integrada com os elementos estruturadores: físico, ambiental, psicológico e cultural. O método apresentado e aferido na tese apresenta duas partes distintas: uma etapa quantitativa, na qual avaliou-se os aspectos físicos e ambientais do ambiente urbano em questão, e uma etapa qualitativa, que avaliou a percepção do espaço nas esferas do ambiente, da calçada e do entorno. A conclusão principal reforça a ergonomia aplicada de forma mais abrangente, com os seus elementos estruturadores pode auxiliar e agregar valor nas avaliações e propostas para o ambiente urbano.

Palavras chave: ergonomia, percepção, método avaliação, ambiente urbano.

\section{ABSTRACT}

This research has as main goal to present a proposal of ergonomic evaluation method for the urban environment, in which the ergonomics has an integration feature with the environmental comfort. The research starts from the hypothesis that ergonomics can be understood more comprehensively and integrated with the structural elements: physical, environmental, psychological and cultural. The method presented and assessed in the thesis has two distinct parts: a quantitative step, in which the physical and environmental aspects of the urban environment were evaluated, and a qualitative step that evaluated the perception of space in the spheres of the environment, the sidewalk and the environment. The main conclusion reinforces the application of ergonomics in a more comprehensive way, with its structural elements can benefit and add value in the reviewing and proposals for the urban environment.

Keywords: ergonomics, perception, evaluation method, urban environment. 


\section{AGRADECIMENTOS}

Ao meu marido, pelo companheirismo e compreensão em todos os momentos de dificuldades para finalização da pesquisa;

À amiga Joana Carla S. Gonçalves, pela paciência, pela constante troca de ideias neste processo que muito ajudou na elaboração deste trabalho;

Ao amigo Marcelo A. Romero por todo apoio e incentivo para realização deste trabalho;

Ao amigo Leonardo M. Monteiro, pelas conversas esclarecedoras;

A todos os colegas do LABAUT pela compreensão, principalmente nesta etapa final do trabalho;

À Regina, Clara e Sandra por todo apoio para finalização deste trabalho;

Ao apoio, profissionalismos e paciência de Eduardo Gasparelo, principalmente nesta etapa final, sem o qual não seria possível a sua finalização;

Às funcionárias do AUT/FAU, Eliane, Fátima, Andreia e Viviane pelo constante apoio durante as atividades realizadas para a pesquisa;

Aos funcionários da Acadêmica da FAUUSP, por todos os esclarecimentos e auxílio na etapa final do trabalho;

Aos funcionários da gráfica da FAUUSP, por todo empenho e dedicação

Às agências de fomento à pesquisa CAPES, CNPQ e FAPESP que têm apoiado meu trabalho de diversas maneiras, em diferentes momentos.

A todos aqueles que direta ou indiretamente contribuíram para a finalização deste trabalho 


\section{SUMÁRIO}

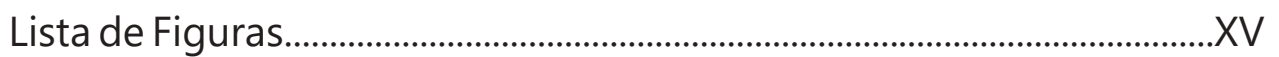

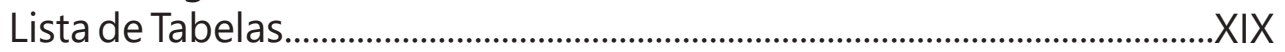

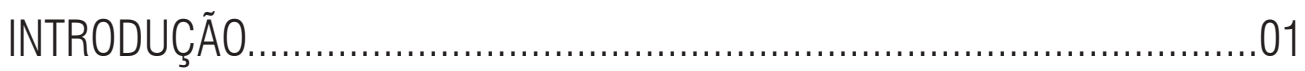

PARTE 01

CAPÍTULO 01 - MÉTODOS E TÉCNICAS ....................................................05

CAPÍTULO 02 - O CONFORTO AMBIENTAL ENTRE O AMBIENTE CONSTRUÍDO, O USUÁRIO E A PERCEPÇÃO DO ESPAÇO: A

ERGONOMIA COMO ELO ESTRUTURADOR ……………….......................09

- Ergonomia e Percepção: em busca de novos referenciais .................11

- Psicologia ambiental Vs Ergonomia do ambiente .................................19

- O Homem e o Espaço .....................................................................................22

- A Ergonomia em busca de sua identidade: Conceitos e

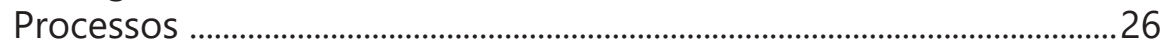

- Cidades e Mobilidade: importância do caminhar....................................30

- Em busca do conforto ao caminhar: a ergonomia e a avaliação

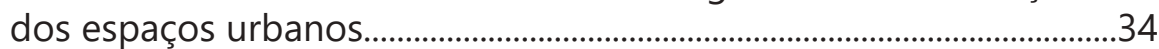

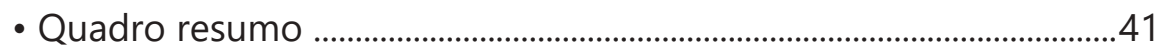

\section{CAPÍTULO 03 - MÉTODOS DE REFERÊNCIA: ERGONOMIA COMO}

PARÂMETRO INTEGRADOR DO CONFORTO AMBIENTAL

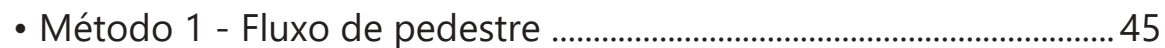

- Método 2 - Atrativos para o pedestre - Southworth ...........................4

- Método 3 - Transporte alternativo - Pozueta ...........................................48

- Método 4 - Sala da calçada - Active Design .............................................50

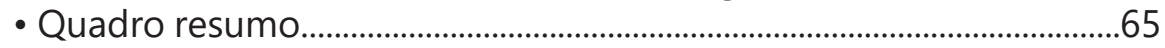

PARTE 02

CAPÍTULO 04 - APLICAÇÕES DOS MÉTODOS DE REFERÊNCIA NO AMBIENTE URBANO

- Aplicação do Método 1: Desenho urbano, mobilidade e fluxo de pedestres

- Aplicação dos Métodos 2 e 3: Adensamento urbano com qualidade ambiental, mobilidade e acessibilidade

- Aplicação dos Métodos 2, 3 e 4: Funções e atividades da habitação. Áreas externas: expectativas e necessidades de conforto e bem-estar

- Aplicação do Método 1 e 4: Paraisópolis: Avaliação sob o enfoque ergonômico dos espaços externos

- Quadro resumo. 


\section{CAPÍTULO 05 - PROPOSTA DE MÉTODO PARA AVALIAÇÃO ERGONÔMICA DO AMBIENTE URBANO}

- Análise quantitativa

- Análise qualitativa

- Quadro resumo

\section{CAPÍTULO 06 - APLICAÇÃO DO MÉTODO DE AVALIAÇÃO}

- Verificação do método proposto: Safari Urbano

- Aplicação do métoodo proposto: Entorno das Estações da CPTM na Marginal Pinheiros

Entorno da Estação Berrini da CPTM ................................................142

Entorno da Estação Vila Olímpia da CPTM ....................................152

Entorno da Estação Santo Amaro da CPTM ...................................162

- Percepção dos usuários

- Discussão dos resultados obtidos ............................................................178

- Quadro resumo

CONCLUSÃO 


\section{LISTA DE FIGURAS}

Figura 1: Fluxograma da pesquisa. Fonte: Elaborado pela autora.

Figura 2: Definição de Ergonomia. Fonte: AUT 5838 - Percepção, espaço e mobilidade: interações com o Conforto Ambiental

Figura 3: Fatores ergonômicos. Fonte: AUT 5838 - Percepção, espaço e mobilidade: interações com o Conforto Ambiental.

Figura 4: Seis categorias e 21 indicadores da ferramenta de cálculo "Índice de Caminhabilidade" proposta pelo ITDP. Fonte: ITDP, 2016.

Figura 5: Organização das calçadas segundo Programa Passeio Livre. Fonte: Cartilha Programa Passeio Livre da Prefeitura de São Paulo.

Figura 6: Níveis de Serviço elaborado pelo autor segundo o HCM (2000). Fonte: CARVALHO, 2006, P. 34.

Figura 7: Julgando pela perspectiva do pedestre, a calçada é formada por quatro planos: o do chão, o da estrada, o da parede e o da cobertura. Fonte: CIDADE DE NOVA IORQUE, 2013.

Figura 8: Os pedestres experimentam a calçada com seus sete sentidos. Fonte: CIDADE DE NOVA IORQUE, 2013.

Figura 9: Planos da rua. Fonte: CIDADE DE NOVA IORQUE, 2013.

Figura 10: Ilustração a ser estudada. Fonte: CIDADE DE NOVA IORQUE, 2013.

Figura 11: Croqui de um plano do chão. Fonte: CIDADE DE NOVA IORQUE, 2013, P. 48.

Figura 12: Croqui de um plano da rua. Fonte: CIDADE DE NOVA IORQUE, 2013.

Figura 13: Croqui de um plano da cobertura. Fonte: CIDADE DE NOVA IORQUE, 2013, P. 56.

Figura 14: Croqui de um plano do edifício. Fonte: CIDADE DE NOVA IORQUE, 2013, P. 60.

Figura 15: Planta de piso proposta pelo método norte-americano. Fonte: CIDADE DE NOVA IORQUE, 2013.

Figura 16: Elevação das fachadas. Fonte: CIDADE DE NOVA IORQUE, 2013.

Figura 17: Corte da calçada. Fonte: CIDADE DE NOVA IORQUE, 2013.

Figura 18: Corte da via. Fonte: CIDADE DE NOVA IORQUE, 2013.

Figura 19: Base para a elaboração da perspectiva do piso. Fonte: CIDADE DE NOVA IORQUE, 2013.

Figura 20: Perspectiva da calçada. Fonte: CIDADE DE NOVA IORQUE, 2013.

Figura 21: Croqui de uma calçada. Fonte: CIDADE DE NOVA IORQUE, 2013.

Figura 22: A altura entre o chão e a divisão entre os dois primeiros pavimentos do edifício é a mais importante na escala do pedestre. Fonte: CIDADE DE NOVA IORQUE, 2013, P. 33.

Figura 23: Variedade na dimensão horizontal. Em laranja, a escala da unidade. Em azul, a escala do edifício e em cinza, a escala da quadra. Fonte: CIDADE DE NOVA IORQUE, 2013, P. 34.

Figura 24: Níveis de Serviço elaborado pelo autor segundo o HCM (2000). Fonte: CARVALHO, 2006, P. 34.

Figura 25: Planta com novas larguras da Rua Barão de Iguape. Fonte: Elaborado por Meire Nakamura.

Figura 26: Corte com novas larguras da Rua Barão de Iguape. Fonte: Elaborado por Meire Nakamura. 
Figura 27: Bela Vista: Mapa área. Fonte: Elaborado por Julia Galves.

Figura 28: Ficha síntese do levantamento feito na Alameda Campinas - Bela Vista. Fonte: Elaborado por Júlia Galves.

Figura 29: República: Mapa da área e entorno. Fonte: Elaborado por Julia Galves.

Figura 30: República: Ficha síntese do levantamento feito na Rua Timbiras - República. Fonte: Elaborado por Júlia Galves.

Figura 31: Sugestão de modificação da via. Fonte: Elaborado por Julia Galves.

Figura 32: Parte da análise qualitativa da Rua da Consolação. Fonte: Desenhos de Isabela Belini.

Figuras 33 e 34: Imagens das medições em campo. Fonte: Fotos de Naima Manfre.

Figura 35: Mapa Paraisópolis com o trecho (rua e viela) e as casas selecionados. Fonte: Elaborado por Claudia Carunchio.

Figura 36: Legenda da localização dos obstáculos: levantamentos. Fonte: Elaborado por Claudia Carunchio.

Figura 37: Levantamento Paraisópolis na rua - obstáculos. Fonte: Elaborado por Claudia Carunchio.

Figura 38: Corte esquemático das ruas de Paraisópolis, com representação dos obstáculos presentes nas calçadas e da área utilizada para a circulação pelos pedestres. Fonte: Elaborado por Claudia Carunchio.

Figura 39: Pedestres circulando pelo leito carroçável.Fonte: Foto de Claudia Carunchio.

Figura 40: Poluição visual causada pelos fios de eletricidade / Pessoas caminhando junto aos carros "ausência" de calçadas. Fonte: Foto de Claudia Carunchio.

Figuras 41 e 42: Parklets em São Paulo. Fonte: http://www1.folha.uol.com.br/ saopaulo/2014/09/1518236-conheca-os-parklets-minipracas-instaladas-em-vagas-de-carros.shtml.

Figura 43: Proposta de utilização das calçadas Paraisópolis. Corte esquemático Fonte: Desenho de Claudia Carunchio.

Figura 44: Proposta de utilização das calçadas Paraisópolis. Planta esquemática. Fonte: Desenho de Claudia Carunchio.

Figura 45: Levantamento Paraisópolis na viela - largura. Fonte: Elaborado por Claudia Carunchio.

Figuras 46 e 47: Obstáculos nas vielas. Fonte: Fotos de Claudia Carunchio.

Figura 48: Piso irregular. Fonte: Foto de Claudia Carunchio.

Figura 49: Fluxograma do método proposto. Fonte: Elaborado pela autora.

Figura 50: Escala qualitativa de satisfação do pedestre para as questões da entrevista. Fonte: Elaborado pela autora.

Figura 51: Questões da entrevista em formato de aplicação para os pedestres. Fonte: Elaborado pela autora.

Figura 52: Apresentação resultante da sintetização das análises quantitativas feitas no Safári Urbano. Os resultados numéricos referem-se à temperatura do ar (em $\left.{ }^{\circ} \mathrm{C}\right)$, umidade relativa (em \%), temperatura do globo $\left(\mathrm{em}{ }^{\circ} \mathrm{C}\right)$ e nível de ruído (em $\mathrm{dB}(\mathrm{A})$ ), respectivamente. Na parte periférica dos gráficos encontra-se as medidas obtidas no Safari. Na parte central, os resultados dos questionários. Fonte: Elaborado por Eduardo Pizarro.

Figura 53: Estação Berrini e enterno. Fonte: Elaborado por Gabriel Novaes.

Figura 54: Estação Vila Olímpia e enterno. Fonte: Elaborado por Gabriel Novaes.

Figura 55: Estação Santo Amaro e enterno. Fonte: Elaborado por Gabriel Novaes.

Figura 56: Escala qualitativa de satisfação do pedestre para as questões da entrevista. Fonte: Elaborado pela autora. 
Figura 57: Questões da entrevista em formato de aplicação para os pedestres. Fonte: Elaborado pela autora.

Figura 58: Estação Berriri da CPTM e área levantada no EMBARQ Brasil. Fonte: Elaborado por Gabriel Novaes.

Figuras 59-63: Saída da Estação Berrini, do lado da R. Joel Carlos (Trecho 1). Fonte: Acervo LABAUT.

Figuras 64-66: Calçada da pista local da Av. Marginal Pinheiros, em frente ao Edifício Plaza Centenário (Trecho 2). Fonte: Acervo LABAUT.

Figuras 67-72: Calçadas da R. Joel Carlos Borges, entre os $N^{\circ} 60$ e 92 (Trecho 3). Fonte: Acervo LABAUT.

Figura 73: Estação Vila Olímpia da CPTM e área levantada no EMBARQ Brasil. Fonte: Elaborado por Gabriel Novaes.

Figuras 74-79: Saída da Estação Vila Olímpia, do lado da R. Beira Rio (Trecho 1). Fonte: Acervo LABAUT.

Figuras 80-85: Saída da Estação Vila Olímpia, do lado da Av. Marginal Pinheiros (Trecho 2). Fonte: Acervo LABAUT.

Figuras 86-91: Calçadas da R. Funchal próximas à R. Gomes de Carvalho (Trecho 3). Fonte: Acervo LABAUT.

Figura 92: Estação Santo Amaro da CPTM e área levantada no EMBARQ Brasil. Fonte: Elaborado por Gabriel Novaes.

Figuras 93-96: Saída da Estação Santo Amaro, do lado da Av. Pe. José Maria (Trecho 1). Fonte: Acervo LABAUT.

Figuras 97-99: Av. Pe. José Maria, na calçada oposta à Estação Santo Amaro (Trecho 2). Fonte: Acervo LABAUT.

Figuras 100-102: R. Engenheiro Francisco Pitta Brito, entre os $N^{\circ} 255$ e 425 (Trecho 3). Fonte: Acervo LABAUT. 


\section{LISTA DE TABELAS}

Tabela 1: Sistema de pontuação final da ferramenta, a partir de média aritmética dos indicadores avaliados. Fonte: ITDP, 2016.

Tabela 2: Tabela comparativa de larguras de faixa livre. Fonte: Elaborado por Meire Nakamura.

Tabela 3: Tabela comparativa de larguras totais. Fonte: Elaborado por Meire Nakamura.

Tabela 4: Fluxo de carros e pedestres na Bela Vista. Fonte: Elaborado por Júlia Galves.

Tabela 5: Fluxo de carros e pedestres na República. Fonte: Elaborado por Júlia Galves.

Tabela 6 : Levantamento dos passeios - Bela Vista. Fonte: Elaborado por Júlia Galves.

Tabela 7: Levantamento dos passeios - República. Fonte: Elaborado por Júlia Galves.

Tabela 8: Ficha resumo de aplicação dos critérios de análise nos trechos estudados Freguesia do Ó, Trecho 1: Rua Dr. Estevão Montebelo. Fonte: Elaborado por Isabela Belini.

Tabela 9: Ficha resumo de aplicação dos critérios de análise nos trechos estudados Freguesia do Ó, Trecho 2: Rua Mns. Januário Sangirardi. Fonte: Elaborado por Isabela Belini.

Tabela 10: Ficha resumo de aplicação dos critérios de análise nos trechos estudados Consolação, Trecho 1: Rua da Consolação. Fonte: Elaborado por Isabela Belini.

Tabela 11: Ficha resumo de aplicação dos critérios de análise nos trechos estudados Consolação, Trecho 2: Rua Da. Antônia de Queirós. Fonte: Elaborado por Isabela Belini.

Tabela 12: Análise Paraisópolis com o trecho (rua e viela). Fonte: Elaborado por Cláudia Carunchio.

Tabela 13: Fluxo de pedestres. Fonte: Elaborado por Cláudia Carunchio.

Tabela 14: Análise Paraisópolis com o trecho viela. Fonte: Elaborado por Cláudia Carunchio.

Tabela 15: Quadro resumo - Ciclovias. Fonte: Elaborado pela autora.

Tabela 16: Quadro resumo - Estacionamentos. Fonte: Elaborado pela autora.

Tabela 17: Quadro resumo - Uso misto do solo. Fonte: Elaborado pela autora.

Tabela 18: Quadro resumo - Presença de atrativos verdes. Fonte: Elaborado pela autora.

Tabela 19: Quadro resumo - Proximidade a meios de transporte coletivo. Fonte: Elaborado pela autora.

Tabela 20: Quadro resumo - Calçadas. Fonte: Elaborado pela autora.

Tabela 21: Quadro resumo - Velocidade das vias. Fonte: Elaborado pela autora.

Tabela 22: Quadro resumo - Percepção do espaço. Fonte: Elaborado pela autora.

Tabela 23: Quadro resumo - Fluxo de carros. Fonte: Elaborado pela autora.

Tabela 24: Quadro resumo - Fluxo de pedestre. Fonte: Elaborado pela autora.

Tabelas 25-32: Fichas para aplicação. Fonte: Elaborado pela autora.

Tabela 33: Questionário para entrevista de percepção ambiental do pedestre. Fonte: Elaborado pela autora.

Tabela 34: Modelo das entrevistas utilizado no Safári Urbano realizado pelo Laboratório de Conforto Ambiental e Eficiência Energética da Faculdade de Arquitetura e Urbanismo da Universidade de São Paulo (LABAUT da FAU USP). Fonte: Modelo produzido pelo próprio LABAUT da FAU USP.

Tabelas 34-41: Fichas para aplicação. Fonte: Elaborado pela autora. 
Tabela 42: Questionário para entrevista de percepção ambiental do pedestre. Fonte: Elaborado pela autora.

Tabela 43: Tabela síntese dos questionários aplicados no Trecho 1 da Estação Berrini. Fonte: Elaborado pela autora.

Tabela 44: Tabela síntese dos questionários aplicados no Trecho 2 da Estação Berrini. Fonte: Elaborado pela autora.

Tabela 45: Tabela síntese dos questionários aplicados no Trecho 3 da Estação Berrini. Fonte: Elaborado pela autora.

Tabela 46: Tabela síntese dos questionários aplicados no Trecho 1 da Estação Vila Olímpia. Fonte: Elaborado pela autora.

Tabela 47: Tabela síntese dos questionários aplicados no Trecho 2 da Estação Vila Olímpia. Fonte: Elaborado pela autora.

Tabela 48: Tabela síntese dos questionários aplicados no Trecho 3 da Estação Vila Olímpia. Fonte: Elaborado pela autora.

Tabela 49: Tabela síntese dos questionários aplicados no Trecho 1 da Estação Santo Amaro. Fonte: Elaborado pela autora.

Tabela 50: Tabela síntese dos questionários aplicados no Trecho 2 da Estação Santo Amaro. Fonte: Elaborado pela autora.

Tabela 51: Tabela síntese dos questionários aplicados no Trecho 3 da Estação Santo Amaro. Fonte: Elaborado pela autora. 
Este trabalho tem como objetivo principal apresentar proposta Ede método de avaliação ergonômica para o ambiente urbano, no qual a ergonomia possui um caráter de integração com o conforto ambiental.

A pesquisa parte da hipótese que a ergonomia pode ser entendida de forma mais abrangente e integrada com os elementos estruturadores: físico, ambiental, psicológico e cultural.

Com base na mudança de entendimento da ergonomia além dos aspectos físicos e ambientais, são introduzidas novas dimensões de avaliação: a cultural e a psicológica.

A partir de algumas contextualizações e classificações, mostrase a importância da inserção da ergonomia com seus elementos estruturadores (físico, ambiental, cultural e psicológico) no processo de projeto, não só como elo estruturador entre o conforto ambiental e o ato de projetar, mas também como forma de reforçar a sua identidade no ambiente construído.

A pesquisa parte do pressuposto que a ergonomia trabalha com a relação da Arquitetura e o Meio através das sensações e estímulos. Consequentemente se torna desejável que todo o processo de avaliação no qual haja participação da ergonomia exista a interação dos elementos estruturadores.

Após apresentar no capítulo inicial os métodos e técnicas utilizados para esta tese, segue a primeira parte do trabalho, que possui dois capítulos. No primeiro capítulo, a partir da discussão do cenário atual global, apresenta-se a necessidade de diminuição dos impactos ambientais gerados pelas cidades e pelos edifícios. Discorrese sobre a importância do papel das escolas de Arquitetura e Urbanismo, em especial do ensino da ergonomia como instrumento no processo de projeto e de mudanças estruturais relacionadas a este contexto. Também é contextualizado e caracterizado alguns aspectos relacionados a ergonomia, ao conforto ambiental, a avaliação do ambiente urbano, percepção do espaço, mobilidade e o ambiente urbano com ênfase no pedestre.

No segundo capítulo, a partir do pressuposto da necessidade de mudança de padrões para a utilização do transporte público, de alterações profundas na organização e estruturação dos meios de transporte das grandes metrópoles, e consequentemente adequações em aspectos ligados à mobilidade dos cidadãos, são 
selecionados alguns métodos de referência para validação da hipótese. De acordo com a ótica da ergonomia e dos pedestres nos espaços urbanos, são apresentados os métodos: Highway Capacity Manual - HCM (2000); Southworth (2005), Pozueta (2005) e o Active Design, do Departamento de Planejamento de Nova lorque (2013).

A segunda parte mostra aplicações dos métodos de referência. Como aplicação dos métodos de referência, para o capítulo quatro foram selecionados quatro trabalhos. O trabalho intitulado: Desenho Urbano, Mobilidade e fluxo de pedestres aborda aspectos relacionados ao adensamento urbano e as formas de aferição dos fluxos de pedestres no ambiente urbano e o consequente dimensionamento das calçadas. Os resultados encontrados foram aplicados nos trabalhos subsequentes. O segundo trabalho intitulado: Adensamento urbano com qualidade ambiental, mobilidade e acessibilidade abordou o método proposto sob a ótica da avaliação do ambiente urbano com critérios e parâmetros estabelecidos dentro dos métodos de referência apresentados. O terceiro trabalho intitulado: Funções e atividades da habitação: áreas externas: expectativas e necessidades de conforto e bemestar, além de retomar os critérios e parâmetros estabelecidos no segundo trabalho trouxe a aplicação do método a partir de variáveis qualitativas. O último trabalho intitulado: Paraisópolis: avaliação, sob o enfoque ergonômico dos espaços externos trouxe a discussão da aplicação dos métodos de referência em áreas de habitação com caráter social com diversidades não encontradas nos espaços urbanos ditos "convencionais".

Na sequência, a partir das considerações sobre a aplicação dos métodos de referência é apresentada a proposta de método de avaliação ergonômica do ambiente urbano. Além da avaliação quantitativa e a incorporação das variáveis de conforto térmico, acústico e luminoso, houve a avaliação de aspectos qualitativos e de percepção do usuário. Os levantamentos para a aferição do método foram realizados na região da Av. Berrini, entre as estações de trem da CPTM Vila Olímpia, Berrini e Santo Amaro.

Além das conclusões e dos possíveis desdobramentos do método aqui proposto, apresenta-se, como desfecho do trabalho algumas considerações sobre a inserção da ergonomia no ambiente construído. 

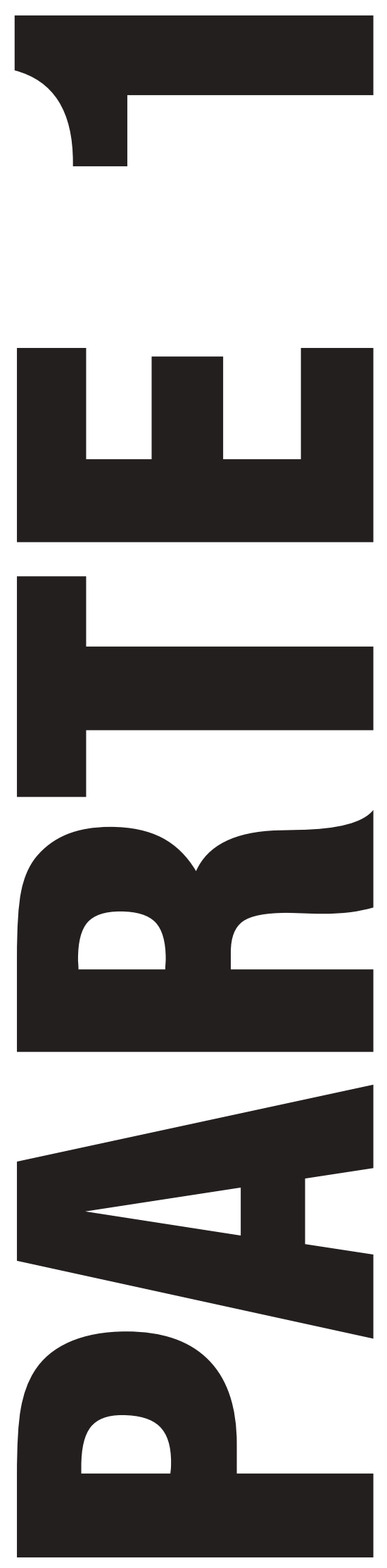
O objetivo deste capítulo é mostrar como esta pesquisa foi estruturada, bem como os passos percorridos para a proposição do método aqui apresentado.

A seguir o fluxograma da pesquisa:

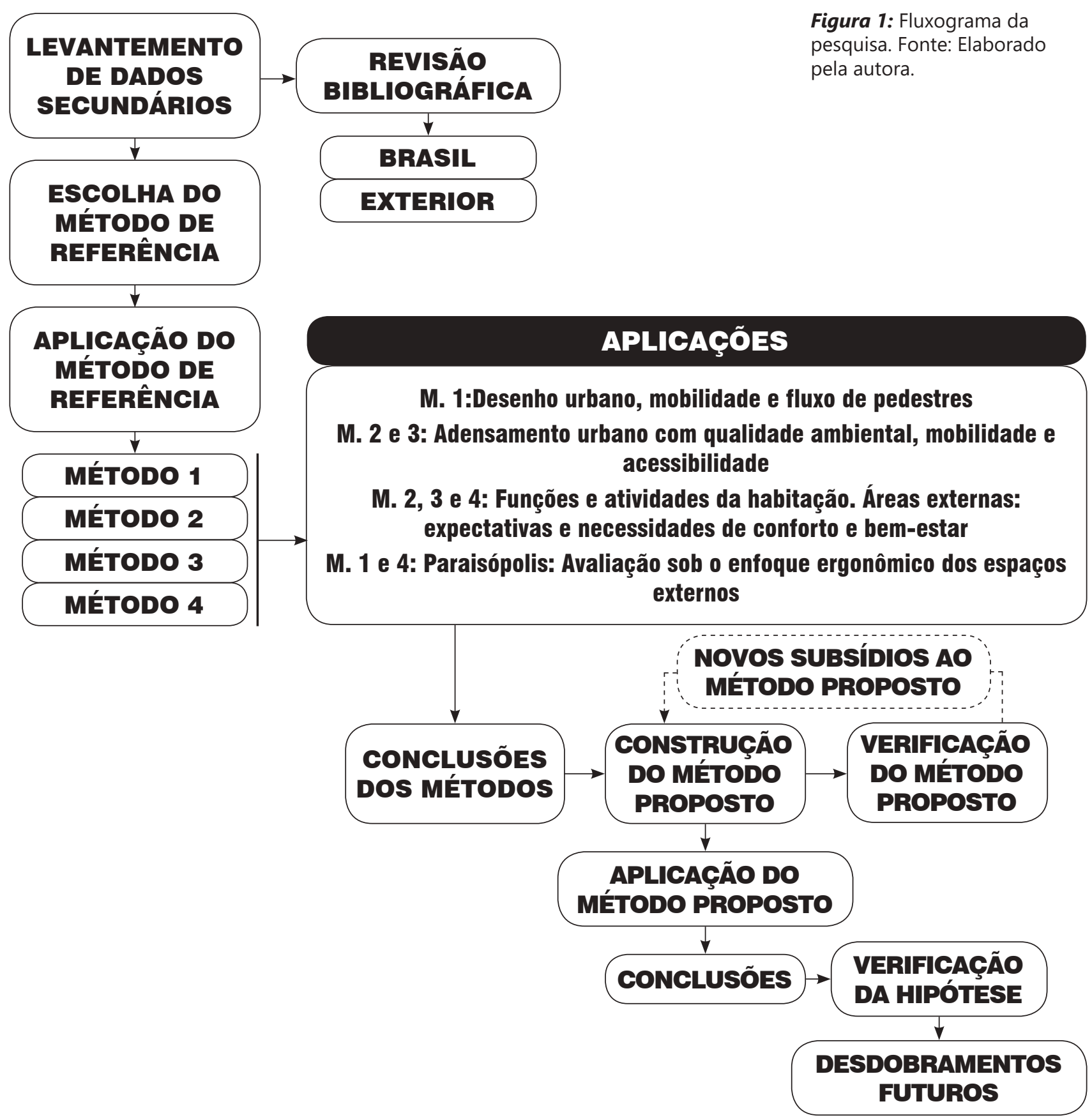


Com o levantamento de dados secundários efetuou-se a revisão bibliográfica, tanto de referências no Brasil, como no exterior, na qual se pode contextualizar aspectos conceituais abordados, como também selecionar os métodos de referência apresentados dentro dos pressupostos da tese.

A ergonomia, a percepção, o comportamento do usuário e a necessidade de incorporação de novos referenciais para efetivar o elo entre o projeto e a área do conforto ambiental são aspectos percorridos no capítulo dois para introduzir os elementos estruturadores propostos. Intitulado: O Conforto Ambiental entre o ambiente construído, o usuário e a percepção do espaço: a ergonomia como elo estruturador, este capítulo subdivide-se em alguns subtemas dentro a abordagem principal: Ergonomia e percepção: em busca de novos referenciais; Psicologia Ambiental $x$ Ergonomia do Ambiente; o Homem e o Espaço; A Ergonomia em busca de sua identidade: conceitos e processos; Cidades e Mobilidade: a importância do caminhar e Em busca do conforto ao caminhar: a ergonomia e a avaliação dos espaços.

No terceiro capítulo são apresentados os métodos de referência escolhidos, dentro dos pressupostos da tese, para a sua aplicação. Foram selecionados:

- Método 01-Fluxo de Pedestres: Baseado no Highway Capacity Manual (HCM) - Pedestrian Concepts. A partir do fluxo, velocidade e densidade dos pedestres na calçada o método procura estabelecer a adequação do dimensionamento das calçadas.

- Método 02 - Atrativos para o pedestre - Southworth: $\mathrm{O}$ método propõe a utilização de atributos indispensáveis para tornar o meio urbano mais atrativo para o pedestre, sendo eles: conectividade; ligação com outros meios; uso misto do solo; segurança; qualidade do caminho e contexto do caminho.

- Método 03 - Transporte alternativo - Pozueta: O método propõe uma "mobilidade sustentável" a partir da promoção do deslocamento em bicicleta e do deslocamento a pé.

- Método 04 - Sala da Calçada - Active Design: O método proposto pelo Departamento de Planejamento de Nova lorque é composto por dois processos: o primeiro envolve a elaboração de desenhos de uma quadra, como plantas, elevações, cortes e perspectivas, e o segundo que envolve uma avaliação qualitativa e quantitativa do ambiente urbano em questão.

Com o objetivo de avaliar parâmetros para a proposição do 
método da tese, realizou-se no capítulo seguinte a aplicação dos métodos de referência em quatro trabalhos selecionados. Convém observar, que a aplicação destes métodos não ocorreu de forma separada, havendo trabalhos que aplicaram dois ou três dos métodos de referência aqui selecionados, conforme pode ser observado a seguir:

- Aplicação do Método 01 - Desenho Urbano, Mobilidade e fluxo de pedestres. $O$ trabalho abordou aspectos relacionados ao adensamento urbano e as formas de aferição dos fluxos de pedestres no ambiente urbano e o consequente dimensionamento das calçadas

- Aplicação dos Métodos 01, 02 e 03 - Adensamento urbano com qualidade ambiental, mobilidade e acessibilidade. $O$ trabalho abordou a avaliação dos ambientes urbanos, na área da Bela Vista e República, não só a partir dos fluxos de pedestres, mas também a partir de parâmetros sugeridos de qualidade ambiental dentro dos métodos de atrativos para o pedestre (02) e da mobilidade sustentável (03).

- Aplicação dos métodos 02, 03 e 04 - Funções e atividades da habitação: áreas externas: expectativas e necessidades de conforto, bem-estar. $\mathrm{O}$ trabalho abordou a avaliação dos ambientes urbanos, na área da Consolação e da Freguesia do Ó, a partir de parâmetros sugeridos de qualidade ambiental dentro dos métodos de atrativos para o pedestre (02), da mobilidade sustentável (03) e da sala da calçada - Active Design (04).

- Aplicação dos métodos 01 e 04 - Paraisópolis: avaliação, sob o enfoque ergonômico dos espaços externos. $O$ trabalho trouxe a discussão da aplicação dos métodos de referência fluxos de pedestres (01) e sala da calçada - Active Design (4) em áreas de habitação com caráter social com diversidades não encontradas nos espaços urbanos ditos "convencionais".

Após a aplicação dos métodos de referência nestes quatro trabalhos, houve a definição dos parâmetros a serem utilizados para a construção do método proposto na tese. O capítulo cinco apresenta o método completo com a etapa quantitativa, critérios estabelecidos, fichas de utilização em campo, como também a etapa qualitativa, com as questões sugeridas para avaliação da percepção ambiental do pedestre (ambiente, calçada e entorno).

É importante observar que a partir desta definição do método ocorreu em um primeiro momento, um pré-teste de validação. Como resultado verificou-se novos subsídios para o método proposto. 
Finalmente após a validação e incorporação dos novos subsídios, ocorreu a aplicação do método proposto no entorno das Estações da CPTM na Marginal Pinheiros: Berrini, Vila Olímpia e Santo Amaro.

As conclusões, verificação da hipótese e desdobramentos futuros são apresentados no capítulo final da tese. 


\section{Conforto Ambiental entre 0 \\ ambiente contruído, 0 usuário \\ e a percepção do espaço: a \\ ergonomia como elo estruturador}

A partir do cenário atual global, não só de necessidade de diminuição dos impactos ambientais gerados pelas cidades e pelos edifícios, mas também de mudança de paradigma de toda a sociedade frente às questões ambientais, discorre-se, neste contexto, sobre o papel das escolas de Arquitetura e Urbanismo, em especial do ensino do conforto ambiental, com foco na ergonomia tendo como instrumento o processo de projeto.

Com base na mudança de entendimento do conforto ambiental, são introduzidas novas dimensões de avaliação: a cultural e a psicológica. O conforto adaptativo parte do pressuposto que os ocupantes do ambiente construído têm o potencial de se ajustar e encontrar as suas condições de conforto por meio de mudanças individuais (mudanças de roupas, atividades, posturas, ajustes de condições do ambiente, etc...) e questiona várias teorias e métodos existentes, além de trazer para a vitrine o "comportamento do usuário".

A inserção da ergonomia, com seus quatro fatores (físico, ambiental, cultural e psicológico) na avaliação ergonômica, atua como elo estruturador entre o conforto ambiental e o ato de projetar, e surge como forma de reforçar a sua identidade. 


\section{Ergonomia e percepção:}

em busca de novos referenciais
A complexidade envolvida no processo de concepção dos edifícios e espaços urbanos acaba muitas vezes fazendo com que todo o esforço em capacitar os alunos, por meio de um extenso currículo das escolas de Arquitetura e Urbanismo, resulte no efeito contrário, dificultando o processo de síntese necessária na prática do projeto além de não facilitar a inserção e utilização de conceitos específicos na solução adotada, seja no âmbito urbano como no do edifício (SCHIMD, 2005).

O ensino do Conforto Ambiental, principalmente na última década, obteve um expressivo impulso devido ao contexto mundial global de necessidade de redução dos impactos ambientais. A possibilidade de realizar projetos mais eficientes, principalmente do ponto de vista do consumo energético, fez com que aspectos relacionados ao conforto ambiental voltassem a ter a importância devida.

O cenário mundial mostrado pela UNEP - United Nations Environment Programme - no Green Economy Report (2011) reforçou a necessidade de redução das emissões de $\mathrm{CO}_{2}$ e apontou o setor das edificações ${ }^{1}$ tanto residencial como comercial, principalmente nos países em desenvolvimento, com o maior potencial de redução destas emissões ressaltando demandas de projeto com foco no desempenho e na qualidade ambiental. Este cenário considerou tanto os edifícios novos como também o potencial de reabilitação, reiterando não só a importância do setor, como também evidenciando a necessidade de desenvolvimento de nicho de mercado ainda pouco explorado (GONÇALVES, 2015).

A tão aclamada "arquitetura sustentável", "bioclimática", "verde", "passiva", "de baixo impacto ambiental" entre outros termos, apesar de algumas distorções e apelos de "marketing verde", passou a ser sinônimo, no âmbito global, de adaptação do edifício ao clima local, materiais construtivos com desempenho adequado dentro dos critérios de conforto ambiental, ventilação natural, proteção solar, inovação tecnológica, entre outros fatores.

Com este quadro, seria natural e almejável que o ensino de conforto ambiental passasse por revisões e atualizações, não só com o objetivo de renovação curricular e didática, mas principalmente com o objetivo de inserir e facilitar critérios de adequação e conforto ambiental no processo de projeto utilizado pelos alunos. Seria desejável uma constante busca por integrar as avaliações de
[1] No relatório publicado pela UNEP em 2011, os edifícios aparecem como um setor da economia, juntamente com energia, transporte, agricultura, floresta e lixo, reforçando a importância das questões relacionadas ao desempenho e qualidade ambiental. 
conforto ambiental na prática de projeto, no âmbito do conforto térmico, ergonômico, acústico e luminoso, com o objetivo de familiarizar os alunos em métodos mais interativos. Mas, apesar de todo o contexto favorável a revisões e adaptações, o ensino de conforto ambiental, na grande maioria das escolas de arquitetura e urbanismo, com alguns centros de excelência como exceções, ainda tratam as questões relacionadas ao conforto ambiental como reducionista, referindo-se ainda a aspectos da física aplicada às edificações.

A concepção do ensino de conforto ambiental, em disciplinas estanques, previamente definidas, sem inter-relações acaba reforçando o caráter de especificidade em detrimento da prática de projeto e consequentemente prejudica o entendimento destes fatores na espacialidade do projeto (SCHMID, 2005).

A inserção do conforto ambiental, em particular das questões pertinentes à Ergonomia, na concepção e avaliação dos projetos, das edificações existentes e do meio urbano, remete ao questionamento e definição de conforto ambiental, que em quase todas as referências, apesar de suas especificidades, caracteriza uma percepção individual do espaço, de qualidades, influenciada por valores de conveniência, adequação, expressividade, comodidade e prazer (VIRILIO, 1993). Percepção esta, que engloba não só todas as suas variáveis e interferências, mas também vários fatores comportamentais, que poderiam ser classificados em quatro grandes grupos: sócio culturais, psicológicos, ambientais e físicos (HALL, 2005).

Partindo do pressuposto que o conforto ambiental trabalha com a relação da Arquitetura e o Meio através das sensações e estímulos, é desejável que este processo de avaliação do conforto térmico, acústico, ergonômico e luminoso também traga a possibilidade de interação dos fatores físicos, ambientais, psicológicos e culturais.

Não se pode definir quando o conforto se tornou uma preocupação consciente entre as sociedades. Antes de se ter noção do que é esse conceito e de suas implicações, as experiências sensoriais já demonstravam a necessidade de eliminar o desconforto. Embora a consciência do conforto tenha sido construída por um extenso processo cultural, pode-se aliar seu surgimento à ascensão da burguesia urbana, uma vez que se associava o conforto e a decoração da casa ao status e a afirmação da classe social (SCHMID, 2005).

As enfermeiras Katherine Kolcaba e Linda Wilson estudaram o conforto de uma maneira ampla, para além da superação do desconforto. Segundo essas enfermeiras, o conforto desenvolvese em quatro contextos - o físico, o psico-espiritual, o sociocultural 
e o ambiental - podendo alcançar diversos níveis. O contexto físico corresponde às sensações corporais; o psico-espiritual se refere à consciência que o indivíduo tem de si; o sociocultural está associado às relações interpessoais e às tradições familiares; já o ambiental envolve os aspectos externos. Dentro desses contextos, existem três níveis que podem ser alcançados que são o alívio, a liberdade e a transcendência. $O$ alívio corresponde à superação do desconforto, ou seja, à substituição de algo desagradável por algo agradável. A liberdade está relacionada à prevenção do desconforto. A transcendência, por sua vez, é alcançada quando um desconforto inevitável é compensado com outra forma de conforto (SCHMID, 2015).

Aloísio Schmid em A Ideia de Conforto - Reflexões Sobre o Ambiente Construído destaca que os contextos são interdependentes. Os contextos ambiental e corporal apresentam uma relação direta, ou seja, um atua como uma extensão do outro, uma vez que o homem tende a evitar o que lhe agride fisicamente, o que o autor chama de comodidade.

Outro conceito adotado por Schmid é o de expressividade, que diz respeito à interferência do ambiente não sobre aspectos físicos, mas sobre o "estado de espírito" do usuário. O conforto é uma qualidade do espaço arquitetônico, não podendo se reduzir à eliminação do desconforto. A expressividade está muito associada à forma, que é bastante significativa na sensação de acolhimento, e manifesta-se nos contextos psico-espiritual e sociocultural, uma vez que a maneira como interagimos com o ambiente está diretamente associada ao nosso contexto pessoal e cultural. Assim, a noção de conforto também depende das expectativas que os usuários têm em relação às edificações e ao espaço urbano.

A expressividade não está relacionada apenas aos aspectos visuais, mas depende também das qualidades do espaço em aspectos como os táteis, térmicos e olfativos, relacionando-se, assim, ao contexto ambiental, principalmente quando se atinge o nível transcendental, embora o desconforto também seja expressivo.

O conforto é, portanto, uma qualidade do espaço que envolve a percepção e a interpretação de estímulos de diversas ordens, provenientes de fatores como as formas, as dimensões, a iluminação, as cores, a qualidade do ar, os ruídos e as temperaturas. Os estímulos que os usuários recebem dependem, também, da tarefa realizada.

Um dos aspectos mais essenciais no processo da avaliação do conforto ambiental e a percepção espacial é a compreensão de como os indivíduos percebem, assimilam e agem a partir de informações que captam no ambiente à sua volta. É a partir dessa compreensão que as tarefas exercidas em determinado ambiente 
podem ser melhoradas, principalmente em relação ao conforto e à segurança do usuário.

Esses processos têm origem na cognição humana. Segundo Abrahão et al (2009), a cognição é "um conjunto de processos mentais que permite às pessoas buscar, tratar, armazenar $e$ utilizar diferentes tipos de informações do ambiente". Associado a este processo se encontra os processos perceptivos que são um conjunto de processos pelos quais recebemos, reconhecemos, organizamos e entendemos as sensações recebidas dos estímulos ambientais (ABRAHÃO et al., 2009). Dessa maneira, os sentidos humanos se tornam essenciais para esses processos perceptivos. Gehl (2014) classifica-os por sentidos de "distância" - visão, audição e olfato - e sentidos de "proximidade" - tato e paladar. Além desses cinco sentidos mais básicos, há ainda mais dois que influenciam de forma significativa: a propriocepção e o vestibular. A primeira diz respeito a questões de força e posição corporal enquanto que o segundo relaciona as forças da gravidade com a movimentação no espaço (ACTIVE DESIGN, 2013). Dessa maneira, é possível ter certa noção da enorme complexidade que a relação homem $X$ espaço traz consigo.

Para muitos sociólogos, o desenvolvimento das pesquisas em conforto ambiental teve, historicamente, uma estreita ligação entre os avanços nas pesquisas de engenheiros e cientistas no que diz respeito ao aquecimento e resfriamento das residências (CHAPPELS e SHOVE, 2004). Independentemente das necessidades e demandas da época, já se questionava a real necessidade do uso indiscriminado de equipamentos de ar condicionado e de aquecimento. De acordo com Ackerman (2002), o desenvolvimento e difusão do uso do ar condicionado teve uma profunda influência sobre as expectativas e percepções dos consumidores norte americanos em relação à definição social do conforto. Prins (1992) observa que muitos consumidores norte americanos tornaram-se "viciados em ar condicionado".

Relatos como esses sugerem que os significados de conforto são historicamente mutáveis, climaticamente influenciáveis e que os aspectos culturais podem ser influenciados por inovações tecnológicas e refletem estas mudanças. Também é importante observar, que as mesmas características que classificam o edifício moderno e de prestígio, por aspectos culturais, em outros grupos ou comunidades, os tornam completamente insatisfatórios (EVANS, 1980).

Chappels e Shove (2004) identificaram diferentes enfoques do conforto ambiental, sendo eles: conforto tecnologia e sociedade, conforto do edifício, conforto do ambiente externo, conforto, 
saúde e bem estar, conforto cultura e convenção social e conforto e mudança climática. Estas diferentes abordagens, apesar de suas particularidades e objetivos específicos, influenciam na formação de uma visão crítica mais atualizada das avaliações e abordagens do conforto ambiental, e devem influenciar e refletir os conteúdos didáticos abordados nas escolas de Arquitetura e Urbanismo.

Assim como o reconhecimento do contexto histórico e cultural em que os edifícios são desenvolvidos, estudos como os de Rapoport (1976) refletem no questionamento dos métodos utilizados para as abordagens dos elementos de conforto utilizados no processo de projeto. Em sua pesquisa é ressaltada a importância de ter como o objetivo principal o "olhar para os usuários", ou seja, o que possuem seus hábitos, suas características como um grupo social, refletem na consolidação dos ambientes e devem ser aspectos primordiais nas análises de conforto ao invés de se concentrar em definições quantificáveis ou padronizadas de conforto como elemento definidor do projeto. Evans $(1980)$ ressalta a importância de aprender com as "casas tradicionais", uma vez que representam o resultado de muitos anos e até séculos de otimização em relação aos materiais construtivos, organização social, práticas de trabalho e condições climáticas, em um grande aprendizado para os profissionais da área. No entanto, muitas vezes o social e a herança cultural da construção tradicional são ignorados em detrimento da modernização e adoção de conceitos equivocados de padrões de conforto (EVANS. 1980).

Durante o movimento moderno, o conforto foi tratado principalmente em seu aspecto ambiental. Se por um lado as obsessões com certos padrões estéticos levaram a um desligamento em relação às tradições e, assim, à produção de uma arquitetura que muitas vezes era incoerente com o clima e com o local, por outro esse período contemplou avanços tecnológicos e nas ciências relacionadas à física aplicada às edificações. Isso permitiu que aspectos como a iluminação natural e o mobiliário adequado ao corpo humano fossem amplamente trabalhados. Contudo, as residências estavam deixando de ser espaços acolhedores e aconchegantes para se tornarem "máquinas de morar". A ideia de estética útil fez com que o conforto estivesse atrelado a simples ausência de desconforto (SCHMID, 2005).

O termo "conforto" pode ser usado para descrever um sentimento de contentamento, uma sensação de aconchego, ou um estado de bem-estar físico e mental. Questões relacionadas ao conforto foram e são abordadas por sociólogos, biólogos, antropólogos, historiadores, sociólogos, epidemiologistas, geógrafos, psicólogos, arquitetos urbanistas, entre outros profissionais (CHAPPELS e SHOVE, 2004). O objetivo aqui, não é fazer um levantamento 
das diferentes abordagens adotadas e como elas evoluíram, mas sim, relacioná-las, no contexto atual, com a sua real contribuição e interferência não só nas tomadas de decisão relacionadas ao projeto do edifício e das cidades, como também no processo de projeto. É importante ressaltar que estas diferentes abordagens com variadas perspectivas, contribuíram com diferentes enfoques, apoiando ou não, o cenário atual de necessidade de redução dos impactos ambientais e de aquecimento global.

Um importante aspecto a ser destacado é que as alterações dos significados de conforto ao longo do século passado trouxeram significativas implicações na gestão ambiental interna e demanda de energia dos edifícios. Talvez, o aspecto a ser questionado seja justamente até que ponto os edifícios e as cidades respondem às demandas reais de conforto ou apenas refletem convenções sociais e culturais do momento.

Independentemente das abordagens dada ao conforto ambiental com foco na ergonomia deve-se entendê-lo como uma importante ferramenta no processo de projeto, não só por auxiliar o contexto atual de necessidade de redução dos impactos ambientais, mas também por refletir inúmeros aspectos da sociedade.

Todo o panorama mostrado anteriormente, nos leva à reflexão sobre a necessidade de revisão do conceito de conforto ambiental, sobretudo a ergonomia, tanto nos processos de ensino e de aprendizagem, mas também no contexto atual frente às novas demandas.

A partir da década de 70 , o prenúncio da escassez de fontes de energia convencionais, e a crescente escala do impacto ambiental em função da utilização de combustíveis à base de carbono, com o simultâneo aumento da demanda energética decorrente do desenvolvimento econômico e urbano nas regiões mais populosas do mundo, tornaram-se fatores fundamentais para estimular uma revisão crítica dos modelos urbanos e culturais locais (UNEP, 2011). Passou a ser imperativo, neste contexto, o menor consumo de energia, e em alguns casos passou-se até a questionar-se, quando possível, a necessidade ou não desta demanda.

Obviamente este cenário nos leva à reflexão sobre os padrões atuais de conforto, de consumo energético e principalmente da dependência de sistemas ativos para climatização das edificações.

Diante deste quadro, surgem alguns questionamentos. O principal deles é se seria possível estar confortável em um edifício que não é climatizado artificialmente, ou seja, em um edifício que está sujeito às interferências externas de clima. Outro questionamento refere-se à diminuição dos impactos ambientais gerados por 
estes edifícios. A resposta é que os edifícios condicionados por meios naturais podem proporcionar ambientes confortáveis para as pessoas viverem e trabalharem e obviamente a utilização de estratégias que priorizem técnicas passivas reduzem os impactos gerados pelos edifícios. A diferença básica em como se atinge este conforto, em detrimento ao uso de condicionamento artificial é base para a discussão dos parâmetros do "novo conforto ambiental": o comportamento do usuário (ROMERO, 1997).

Antes de verificar as bases do conforto adaptativo, é importante observar que os especialistas de conforto ambiental, que desenvolveram e utilizaram modelos de conforto ambiental por décadas, destacando o desenvolvido por Fanger (1972) (MONTEIRO, 2015), incluindo renomadas instituições, como é o caso da $\mathrm{ASHRAE}^{2}$, reconheceram que a percepção do conforto térmico não é determinada somente por uma resposta fisiológica do corpo humano. Destaca-se que ela também é influenciada pelo fundo cultural e as condições psicológicas associadas com as oportunidades de adaptação às condições ambientais locais.

Neste processo, é importante ressaltar, que o "conforto" que era algo anunciado por décadas como sendo um "produto" a ser comprado, com esta necessária readequação frente ao conforto adaptativo, passou a ser um objetivo a ser alcançado, não só com custos financeiros e ambientais mais baixos, como também com resultados finais com maiores graus de satisfação dos usuários (MONTEIRO, 2015).

Os edifícios de menor impacto ambiental exigem um envolvimento mais proativo entre ocupante, edifício e ambiente, e consequentemente reflete 0 número de técnicas com soluções passivas e se o emprego de técnicas ativas realmente é imprescindível. Este conceito, conhecido também como conforto adaptativo, além de gerar grande economia de energia, também gera maior qualidade ambiental (MONTEIRO, 2015).

O principal pressuposto do conforto adaptativo consiste no fato que os ocupantes dos edifícios têm o potencial de se ajustar e encontrar as suas condições de conforto por meio de mudanças individuais de roupas, atividades, posturas, localização, entre outros. Além disso, existe a possibilidade de ajustes de condições do ambiente, coordenadas pelo usuário do espaço, tais como aberturas de janelas e portas, ajustes de persianas e/ou quebra sol, acionamento de ventiladores, que também funcionam como exemplos de estratégias localizadas de aquecimento ou arrefecimento. Por meio da possibilidade dos ocupantes do edifício interferir no clima interno de acordo com a sua preferência pessoal, é possível conquistar maiores níveis de satisfação e a tão
[2] ASHRAE - American Society of Heating, Refrigerating, and Air-Conditioning Engineers. 
almejada economia de energia.

É muito importante observar que na maioria das vezes os ocupantes que vivem e/ou trabalham em edifícios com ar condicionado desenvolvem altas expectativas sobre as condições internas (principalmente térmicas). Além disso, estes ocupantes acabam não desenvolvendo a habilidade de controlar os seus ambientes e de se acostumar com as variações climáticas.

Além deste vínculo com os ajustes fisiológicos e comportamentais, estas oportunidades de adaptação ligadas ao modelo do conforto adaptativo, estão estreitamente ligadas a uma grande mudança cultural relacionada com a forma como os ambientes internos são utilizados e controlados, nos quais variações climáticas são não só esperadas mas principalmente desejadas.

Esta noção de conforto adaptativo foge à tradicional concepção de algo a ser oferecido por determinado ambiente, mas sim se tornando algo a ser alcançado pelo usuário. 


\section{Psicologia Ambiental Vs Ergonomia do Ambiente}

Segundo Lee (1976) a arquitetura relutou em criar uma base $S$ científica de pesquisa que apoiasse suas teorias. Em geral, grande parte das pesquisas era ligada aos estudos dos materiais a serem empregados, mas poucos analisavam os usuários do espaço. Em registros, quando se trata de arquitetura vernacular, dificilmente se depara com uma observação analisando o ser humano e traçando um paralelo com a função da construção (LEE, 1976 apud PERIN, 1970). Schmid (2005) afirma, inclusive, que até o final do século XVIII, a palavra "conforto" não era empregada à edificação.

Pensando nisso, no século $X X$, com o movimento funcionalista, arquitetos começaram a defender uma arquitetura na qual a forma do edifício é o reflexo da função do espaço (CORBUSIER, 2004). Afinal, se a arquitetura abriga as atividades humanas, deve-se projetar os espaços pensando nos usos previstos e no conforto de seus usuários. Para isso, é importante pensar a função do edifício e o perfil do usuário ao qual a construção se direciona desde o início, considerando sempre, a maneira como o espaço será apropriado pelos indivíduos. Entretanto, seria possível prever a resposta do usuário diante de um espaço ainda não construído?

Tendo em vista essa questão, cientistas, arquitetos, psicólogos, sociólogos, urbanistas, antropólogos e geógrafos se unem para buscar essa resposta desde a década de 60 . Um dos primeiros marcos desse estudo homem $X$ espaço foi a Conferência sobre Psicologia e Psiquiatria Arquitetural em Salt Lake City (EUA) em 1961. A partir desse momento, vários outros encontros ocorreram. $\mathrm{Na}$ Grã-Bretanha, o primeiro significativo foi em Dalahdhui (Universidade de Strathclyde) na Escócia em 1965. Nos Estados Unidos, essa série de conferências levou à criação do EDRA (Environmental Design Research Association) que une profissionais de diversas áreas e possui o mesmo objetivo: a análise entre 0 ambiente e o comportamento dos usuários (LEE, 1976; GIFFORD, 1997).

Neste quadro é importante destacar o papel da Avaliação Pósocupação (APO) que ao apreender sobre o desempenho dos edifícios existentes acredita que é possível prever uma resposta de usuários em ambientes ainda não construídos (PREISER e VISCHER 2005). Desta maneira, avaliação do comportamento do usuário merece ser enfatizada como uma importante ferramenta da APO (PREISER 2015; ORNSTEIN 1995 e ROMERO 1997). 
A APO consiste em um conjunto de métodos e técnicas o qual procura fornecer subsídios para corrigir, sistematicamente, as falhas e verificar acertos, a partir da realimentação do processo de projeto, definindo assim diretrizes para novos projetos afins (ORNSTEIN, 1995). A APO vem sendo aplicada sistematicamente nos países desenvolvidos, a exemplo dos EUA, França, GrãBretanha, Japão, além de outros como a Nova Zelândia, e se baseia no princípio básico de que edificações e espaços livres postos em uso, qualquer que seja a função, devem estar em permanente avaliação, quer do ponto de vista construtivo e espacial, quer do ponto de vista de seus usuários (PREISER e VISCHER 2005).

Por envolver pesquisadores de ramos diversos, Lee (1976) afirma que é inevitável que cada um analise a relação homem $X$ espaço de acordo com seu campo de estudo. Assim, para os psicólogos, esse tema é denominado environmental psychology, environmental sociology e human ecology (CONWAY, 1973). No Brasil há muito pouco estudo sobre o assunto e o termo é traduzido do inglês como Psicologia Ambiental, Ecologia Social ou Estudos Ambiente-Comportamento. Na visão dos arquitetos, esse estudo é denominado Ergonomia do Ambiente ou Ergonomia Ambiental (LEE, 1976; FONSECA, 2004).

A FAUUSP - Faculdade de Arquitetura e Urbanismo da Universidade de São Paulo mostra um papel importante nas pesquisas de APO no Brasil. Desenvolvidas principalmente junto ao Departamento de Tecnologia da Arquitetura da FAUUSP desde 1984, tem focado especialmente a avaliação de edificações, tratando predominantemente de habitações, de edifícios institucionais como escolas e hospitais, de edifícios de escritório, além de áreas livres como praças e parques. Nos últimos anos, os procedimentos de APO também passaram a ser discutidos no contexto mais amplo, da gestão da qualidade do processo de projeto (ORNSTEIN, 1995).

Há muitas discussões que relacionam a Psicologia Ambiental e Ergonomia do Ambiente. Lee (1976) afirma que esta última tem como objeto o estudo da interação entre homem-máquina e a adequação de dimensões e capacidades para que o indivíduo possa alcançar seus objetivos. Nesse caso, ao tratar de "máquina", refere-se tanto a uma cadeira quanto a uma casa. Villarouco (2002) afirma que a ergonomia do ambiente analisa a adaptabilidade e conformidade do espaço às tarefas e atividades nele desenvolvidas. Esse conceito de adaptabilidade é definido por Villarouco (2002) como a resposta da arquitetura às necessidades do usuário, algo que vai além das exigências físicas (dimensionamento), abrangendo também as cognitivas e psíquicas. De maneira geral, o estudo da ergonomia trata de compatibilidade entre o usuário e o edifício, resultando em recomendações para o planejamento dos 
espaços de maneira que eles possam ser funcionais e confortáveis. Baseando-se em conceitos como esses, alguns afirmam que a Psicologia Ambiental é uma parte do estudo da Ergonomia (LEE, 1976).

Por outro lado, Lee (1976) defende em seu texto o contrário: a Ergonomia faz parte da Psicologia Ambiental por duas razões: a primeira é muito mais prática, pois se trata da relação direta entre os dois objetos de estudo, enquanto que a segunda leva em consideração a privacidade, o isolamento, a integração, o espaço pessoal e outros aspectos socioculturais de maneira mais aprofundada.

Entretanto, os dois termos não deixam de ser similares, sendo que as diferenças existem, pois um deles foi criado por arquitetos e engenheiros enquanto o outro foi criado por psicólogos. Os objetivos dos estudos são os mesmos: a relação entre homem e espaço. As diferenças de análise ocorrem pelo objetivo de cada profissão e pela bagagem de conceitos que cada profissional carrega consigo (LEE, 1976). 


\title{
0 Homem e o Espaço
}

\begin{abstract}
A psicologia ambiental defende que o homem é muito mais do um simples observador no espaço, mas também que ele interage com o meio ambiente, com o qual está em intercâmbio constante, ativo, sistemático e dinâmico. Em outras palavras, o usuário está sempre trocando informações com o espaço, seja através dos aspectos físicos ali existentes, seja através das relações sociais presentes. Assim, não se trata do homem e o meio, mas sim o homem no meio (RAPOPORT, 1978).
\end{abstract}

Os estudos concluem que a arquitetura dificilmente pode gerar ou determinar o comportamento dos usuários, seus temperamentos, sua satisfação, interação e atuação de uma forma direta, mas pode facilitar, inibir ou catalisá-los. Rapoport (1978) mostrou que existem efeitos indiretos que influenciam na maneira como as pessoas percebem o ambiente, alterando suas expectativas ou dificultando seu objetivo.

Ornstein (1995 apud Fonseca, 2004) mostra quatro itens importantes na relação entre homem e espaço:

1. O projeto do ambiente construído (e não construído), o uso e a sua operação;

2. As condições de conforto ambiental: iluminação, ventilação, térmica, ruído, insolação;

3. As características do uso, da função do edifício; e,

4. As relações pessoais ali existentes.

O termo percepção segundo Kuhnen (2011) corresponde à maneira como o usuário experimenta o espaço, tanto seus aspectos físicos como sociais, culturais e históricos. Esse processo está ligado ao fluxo de informações e estímulos que o usuário troca com o ambiente aliado à capacidade do seu cérebro de processá-los. Essas informações estão relacionadas tanto com as interações sociais quanto aos aspectos físicos do espaço, além de depender da cultura e personalidade de cada indivíduo (CHENG, 2010; RAPOPORT, 1978; GIFFORD, 1997; LEE, 1976).

O processo de construção da percepção ambiental é complexo e dinâmico (KUHNEN, 2011). O cérebro internaliza constantemente imagens do exterior criadas a partir do ambiente físico e reinterpretadas pelo histórico, cultura e aspectos sociais da ocasião. Assim, as pessoas criam filtros na realidade em que vivem. O observador seleciona, organiza e confere significado ao que 
está sendo observado o que Ihe permite estruturar e identificar o ambiente (KUHNEN, 2011)

Hall (2005) aponta os sentidos com os quais recebe-se os estímulos permitindo o reconhecimento do espaço:

1. Sensorial: visão, olfato, paladar, térmico, tato, audição;

2. Espacial: o sentido da gravidade e do equilíbrio;

3. Sentido do movimento: detalhes do movimento, posturas e equilíbrio;

4. Cinestésico: percepção dos músculos, peso e posição dos membros no espaço. É o sentido mais relacionado ao universo quadridimensional do espaço e tempo.

5. Proxêmico: relação entre homem e espaço e o seu uso e relações;

6. Subconsciente: fome, sede, sexo, respiração, vitalidade, ou seja, a percepção interna do organismo.

Fonseca (2004) afirma que a percepção é o ponto de partida para a atividade humana, pois perceber o espaço permite que nos orientemos nele. Ele ressalta também que a visão é o sentido mais desenvolvido, pois assim como explica Hall (2005), a visão permite um reconhecimento mais amplo e completo do ambiente. Um cego percebe no máximo um raio de $6 \mathrm{~m}$ a $30 \mathrm{~m}$ ao seu redor, enquanto que a visão lhe permitiria ver as estrelas.

O processo de percepção permite a interpretação e a construção de significados que levará ao processo de apropriação e identificação dos ambientes. A apropriação, segundo Cavalcante \& Elias (2011), é resultado da projeção do ser humano no espaço, transformando o local em um prolongamento de sua pessoa. O termo apropriarse também pode se referir a "exercer um domínio", sem que seja necessariamente, ter a posse. Toda atividade humana reflete uma apropriação (CAVALCANTE \& ELIAS, 2011). Apropriar-se de um ambiente, implica a adaptação do espaço a um uso definido pelo usuário e as ações implementadas para atingir-se o objetivo.

A maneira como o usuário percebe o espaço reflete em seu comportamento. A conduta espacial, na maioria das vezes, não é verbalizada e nem consciente. Um ser humano se comunica no silêncio, através de gestos, posturas, distâncias interpessoais, orientação corporal, toque entre outros, ou seja, estamos sempre nos comunicando (PINHEIRO \& ELALI, 2011).

O comportamento espacial é parte do processo de comunicação entre pessoas e um dos mediadores da interação homem e espaço. Para entender melhor o comportamento, é necessário entender os conceitos de espaço pessoal, proxêmica, territorialidade, aglomeração e privacidade (PINHEIRO \& ELALI, 2011). 
O espaço pessoal é uma área que circunda o indivíduo, onde a maioria das interações ocorre, e quando estranhos a penetram, há um desconforto. Essa área pode existir mesmo que a pessoa se encontre isolada. É invisível e intensamente defendida. Sua dimensão depende da personalidade, cultura e história de cada um (PINHEIRO \& ELALI, 2011).

Com relação à proxêmica, Hall (2005) define que os espaços em torno de indivíduo podem ter características:

- fixas (como os edifícios e cômodos onde os usos são claramente definidos);

- semifixas (como o mobiliário, pois existe uma disposição original, mas que pode ser facilmente alterado); ou

- informais (distância mantida entre duas pessoas durante um encontro).

Esse último, Hall (2005) divide em quatro afastamentos: íntima, pessoal, social e pública:

- A distância íntima é aquela em que há contato físico. É dividida em fase próxima (contato direto, corpo a corpo) e fase distante (distância interpessoal de $15 \mathrm{~cm}$ a $20 \mathrm{~cm}$ ).

- A distância pessoal não apresenta contato físico e também apresenta duas fases: próxima $(46 \mathrm{~cm}$ a $76 \mathrm{~cm})$ e a distante $(76 \mathrm{~cm}$ a $1,22 \mathrm{~m})$.

- Na social, alguns traços do rosto já não são mais tão perceptíveis e não há nenhuma intenção ou tentativa de contato, a fase próxima é de $1,22 \mathrm{~m}$ a $2,13 \mathrm{~m}$ e a fase distante é de $2,13 \mathrm{~m}$ a $3,66 \mathrm{~m}$.

- Por fim, na distância pública, as duas pessoas estão fora da área de envolvimento uma da outra. A fase próxima ocorre entre $3,66 \mathrm{~m}$ a $7,62 \mathrm{~m}$ enquanto que a fase distante, a partir de $7,62 \mathrm{~m}$.

A territorialidade, para os animais, corresponde à delimitação física do espaço usado e defendido. Entretanto, o homem demonstra isso de uma maneira mais passiva e sutil, que segundo Pinheiro \& Elali (2011), pode ser mais bem descrito pelo termo "associação contínua de pessoa ou pessoas com um lugar específico". A territorialidade é importante para compreender o comportamento, a vida e as relações interpessoais, porém, sua análise deve ser aliada ao tempo de ocupação do local, os sentimentos relativos a ele, a propriedade e a exclusividade do uso, ligados às regras culturais.

A aglomeração, segundo Pinheiro \& Elali (2011) ocorre quando o indivíduo percebe que precisa de muito mais espaço do que se tem disponível. 
Uma das respostas à aglomeração é a busca pela privacidade, que segundo Altman (1975 apud PINHEIRO \& ELALI, 2011) é um processo dinâmico que busca regular as distâncias interpessoais visando uma situação de equilíbrio entre o isolamento e "manterse acessível a todos". Quando não se obtém esse equilíbrio, há o isolamento ou a invasão de privacidade.

Lee (1976) condena em seu livro, o fato de grande parte dos críticos de arquitetura limitarem seus comentários apenas à estética da obra e não tanto à funcionalidade dela. Apesar de muitos arquitetos defenderem a importância da função do edifício e sua relação com a estética (ZUMTHOR, 2009), a avaliação científica dos usos e dos espaços ainda é considerada experimental e conjetural (LEE, 1976; PINHEIRO, 2004).

O estudo da Psicologia Ambiental e da Ergonomia do Ambiente tem como objetivo buscar o conforto do usuário no ambiente acima de tudo. Afinal, se o espaço não é apropriado para a função à qual se destina, o usuário inevitavelmente fará alterações no projeto, seja quanto ao uso ou quanto ao espaço caso contrário, o ambiente será esquecido e abandonado. Essas interferências podem originar improvisações no espaço que desfiguram os conceitos arquitetônicos pensados anteriormente, na fase de projeto. Como Lee (1976) apontou em seu texto, a arquitetura deve emoldurar o comportamento humano. Ittelson, Proshansky e Rivlin (1970) afirmam que somente depois de conhecer o comportamento do homem no espaço é possível fazer as mudanças desejadas no ambiente.

$\mathrm{Na}$ proposta aqui apresentada da tese, a Ergonomia ao ser entendida de forma mais abrangente e integrada com os seus elementos estruturadores: físico, ambiental, psicológico e cultural, se une à Psicologia Ambiental podendo contribuir de maneira efetiva nas soluções adotadas no ambiente construído. Ou seja, esta abordagem mais ampla, proporciona possibilidade de reforçar o caráter da ergonomia de forma mais abrangente, não só como ligação junto às disciplinas de conforto ambiental, mas também como um elo estruturador entre o ambiente construído, o usuário e a percepção do espaço. 


\section{A Ergonomia em busca de sua identidade:}

Conceitos e processos

[3] Segundo Wisner (2004), o termo ergonomia foi utilizado oficialmente, pela primeira vez, na Inglaterra, em 1947, pelo engenheiro Murrel, com a colaboração do fisiologista Floyd e do psicólogo Welford. Segundo Moraes e Mont'Alvão (2003), o termo ergonomia foi utilizado pela primeira vez, pelo psicólogo inglês, Kenneth Frank Hyevel Muffel, no dia 08 de julho de 1949, na Inglaterra quando pesquisadores formaram a Ergonomic Research Society, com o objetivo de estudar os seres humanos e o ambiente de trabalho.

[4] Segundo Daniellou (2004) a linha europeia foca as atividades do operador, priorizando o detalhamento e o entendimento da tarefa, as informações, a possibilidade de resolução de problemas e de tomadas de decisão; neste caso existe um grande foco na observação da tarefa. Já na linha americana, existe um foco principal nos aspectos físicos na relação homemtarefa (antropométricos, dimensionais, sensoriais, etc.). Moraes e Mont'Alvão (2003) ressaltam que estas linhas não são contraditórias, e sim complementares, cujo enfoque será norteado pelo objetivo principal da análise em questão.
A pesar de algumas discordâncias sobre o surgimento e a utilização do termo ERGONOMIA ${ }^{3}$, é consenso tratar-se de uma área nova, surgida no pós-guerra na Inglaterra, com o objetivo básico de "melhorar" as condições de trabalho nas fábricas em um período que a mão de obra foi explorada até a sua exaustão. O esforço conjunto de pesquisadores de áreas tão diferentes, como a engenharia, a psicologia e a fisiologia traduzir-se-ia na necessidade de "fazer a guerra". Conseguir que os trabalhadores tivessem condições adequadas de trabalho parecia algo razoável e implicaria, na época, em máxima produção no limite do esforço físico.

Segundo a Associação Internacional de Ergonomia - IEA, a ergonomia é o estudo específico das relações entre o homem e seus meios, métodos e ambiente de trabalho (DRURY 2008). Já para a Sociedade de Ergonomia de Língua Francesa - SELF, a ergonomia é a utilização de conhecimentos científicos relativos ao homem e necessários para conceber instrumentos, máquinas e dispositivos que possam ser utilizados pelo maior número de pessoas, com o máximo de conforto, de segurança e eficiência (DANIELLOU 2004). Segundo Wisner (2004) a principal diferença na abordagem da ergonomia na Inglaterra e na França é que a primeira trata da adaptação da máquina ao homem, e a segunda de adaptar o Homem ao trabalho.

O embate entre a produção do conhecimento e a consolidação da profissão do ergonomista, refletiu não só em equívocos na aplicação da ergonomia, como também uma fragilidade conceitual que no caso das escolas de Arquitetura e Urbanismo, apesar de sua importância, resultou, na grande maioria dos casos, na sua supressão dos currículos das disciplinas obrigatórias.

Independentemente das linhas de intervenção existentes, quer seja o enfoque europeu ou no americano ${ }^{4}$ pretende-se aqui discutir e questionar quais os aspectos relevantes e pertinentes dentro de um curso de Arquitetura e Urbanismo, no qual a Ergonomia é parte integrante das disciplinas de Conforto Ambiental.

Wisner (2004) ressalta que a Ergonomia reforça a sua especificidade à medida que considera mais do que somente as "propriedades do homem", ou seja, entenda como o homem usa as suas propriedades em termos da sua história, seus desejos, motivos, experiências e anseios individuais. Ressalta que os aspectos sociais e culturais desempenham um importante papel no processo de adaptação 
do homem à tarefa, e que devem ser avaliados e considerados na avaliação ergonômica.

Carregada por décadas pelo estigma de ciência que estuda a interface do ser humano com o trabalho, a ergonomia passou (e ainda passa) por várias interpretações equivocadas, que enfraqueceram o seu caráter multi e interdisciplinar, reduzindo-a, no caso especifico do projeto de arquitetura, a questões meramente dimensionais, reforçando os aspectos antropométricos e, mais recentemente, relacionados com a acessibilidade.

Entender este "trabalho" como qualquer ação do homem no meio em que se encontra trouxe a real dimensão da ERGONOMIA ${ }^{5}$. Partindo do pressuposto que a Ergonomia na Arquitetura tem como objeto o homem no espaço, podemos defini-la como o estudo das ações e influências mútuas entre o ser humano e o espaço através de interfaces recíprocas. $\mathrm{E}$, desta forma, a principal contribuição da ergonomia na arquitetura e no urbanismo é reforçada em propor relações e condições de ação e mobilidade, definir proporções e estabelecer dimensões em condições especificas em ambientes naturais e construídos, tendo como base o conforto ambiental, que pressupõe a percepção individual de qualidades, influenciada por valores de conven iência, adequação, expressividade, comodidade e prazer.
[5] ERGON (= ação) + NOMOS (= princípios). Apesar de algumas discordâncias entre diferentes escolas, existe um consenso do caráter integrador que caracteriza a Ergonomia e leva à transformação dos vários fatores estruturadores, sendo eles os psicológicos, socioculturais, ambientais e físicos (DANIELLOU, 2004).
Figura 2: Definição de Ergonomia. Fonte: AUT 5838 Percepção, espaço e mobilidade: interações com o Conforto Ambiental

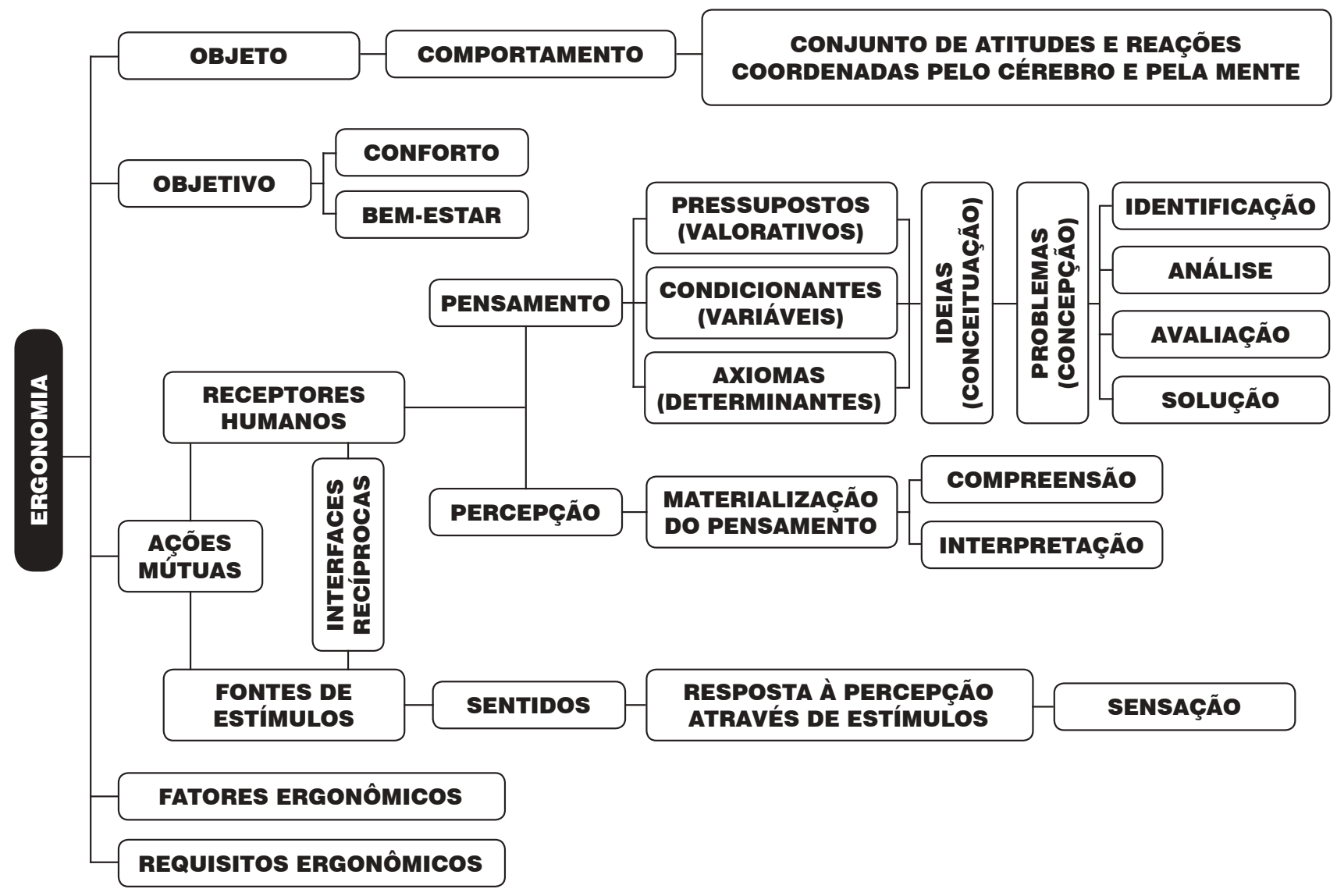




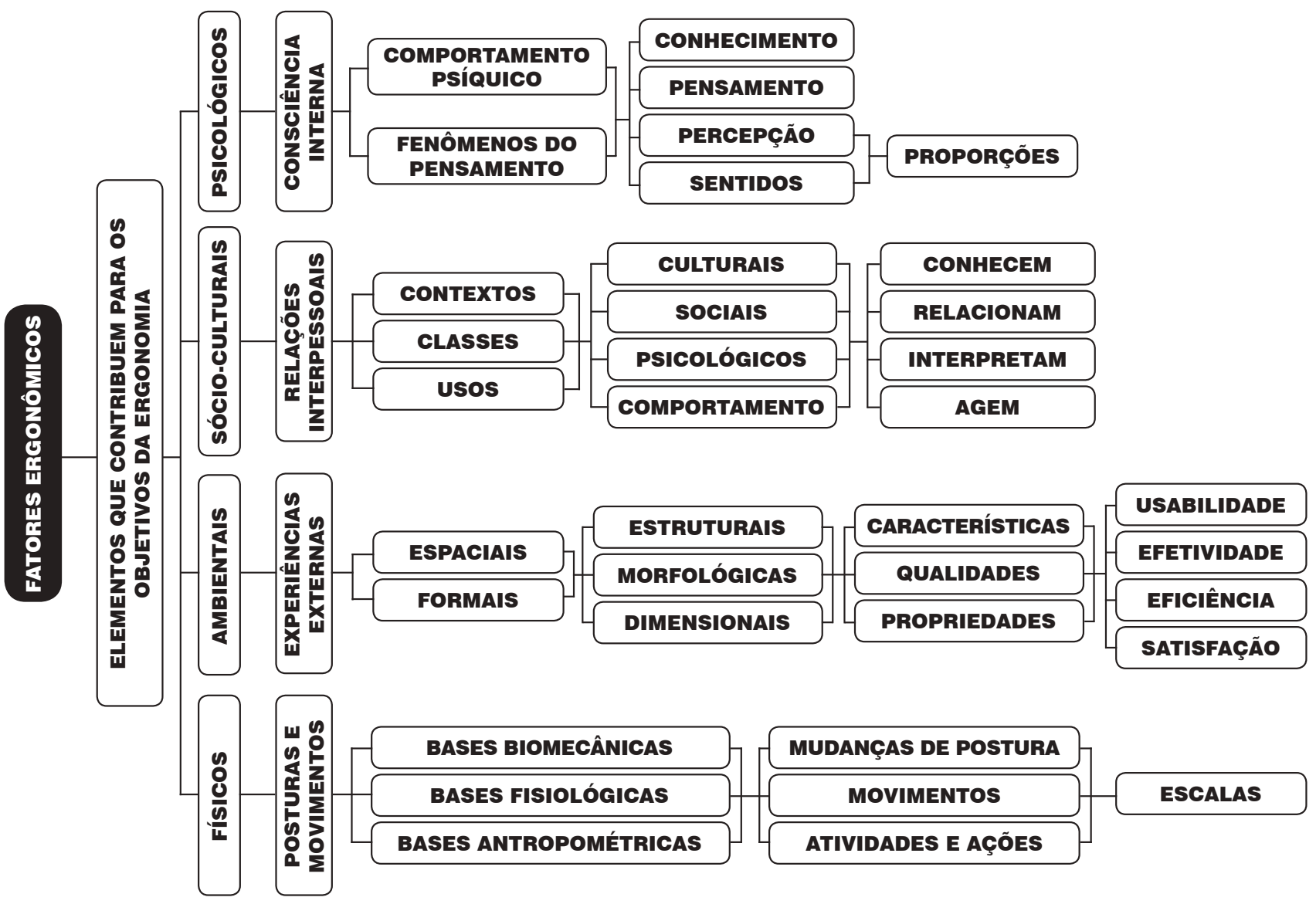

Figura 3: Fatores ergonômicos. Fonte: AUT 5838 - Percepção, espaço e mobilidade: interações com o Conforto Ambiental.

Baseada nestes pressupostos, a ergonomia, a partir de seus quatro fatores estruturadores - os psicológicos, os sócio culturais, os ambientais e os físicos -, embasa ações projetuais que visam conforto. O grande desafio, porém, esteja justamente em como incorporar estes pressupostos em ferramentas no processo de projeto.

Apesar da existência de métodos de conforto ambiental amplamente consolidados nas áreas de conforto térmico, acústico e luminoso, na área de ergonomia, observa-se uma grande quantidade de métodos em fase de amadurecimento, não só para avaliação das atividades humanas no ambiente construído, como também para o entendimento da relação entre o usuário e o ambiente em questão (COSTA, 2014). Todavia, os métodos ergonômicos existentes não auxiliam, na sua grande maioria, no processo efetivo de projeto, e dificultam a integração, desde as etapas iniciais do projeto, das questões relacionadas ao conforto ambiental e as discussões relacionadas ao partido do projeto, bem como todas as inter-relações que possam ocorrer. Esta tese procura contribuir e auxiliar para que a ergonomia seja entendida de forma abrangente e integrada não só com o conforto ambiental, mas também nas etapas de projeto através dos fatores estruturadores: físico, ambiental, psicológico e cultural. 
A escolha do método acaba sendo guiada pelos resultados que se espera obter, e o pesquisador, ou profissional da área, acaba utilizando o método que mais se adequa aos seus objetivos.

Todas as áreas que fazem parte do conforto ambiental - térmica, acústica, iluminação natural e artificial e ergonomia - devem ser avaliadas em conjunto, dentro de um contexto que adequem todas as possíveis interfaces com o projeto procurando estabelecer a relação destas áreas e o comportamento do usuário. Sem esta busca, as questões associadas ao conforto ambiental tendem, na maioria dos casos, a ficarem isoladas, sem conexão com o processo de projeto, apenas cumprindo um protocolo dentro do projeto como um todo.

Talvez uma crítica importante à abordagem convencional das variáveis de conforto no projeto esteja no aprofundamento e detalhamento dos aspectos relacionados com os fatores físicos, em detrimento aos aspectos sócio culturais, psicológicos e ambientais das questões relacionadas com o conforto ambiental como um todo. E este questionamento vem justamente ao encontro com as questões ergonômicas, que em um projeto, na maioria das vezes, restringem-se aos aspectos relacionados ao dimensionamento do espaço em questão. Muito provável, por seu caráter interdisciplinar, ou até mesmo pela sua ausência no currículo de muitos cursos de graduação em arquitetura e urbanismo ${ }^{6}$, a ergonomia muitas vezes é esquecida e até preterida na sua efetiva contribuição. Talvez o ponto central esteja em definir o verdadeiro papel da ergonomia, não só como parte efetivamente integrante das áreas do conforto ambiental, mas também no seu real papel na concepção, estruturação e avaliação de projetos, de edifícios e do ambiente urbano.

Ressalta-se também o fato de que a ergonomia apesar de ser atribuição da profissão do arquiteto e urbanista (segundo lei n. ${ }^{\circ}$ $12.378^{7}$ de 31/12/2010, nas recomendações do MEC - Ministério da Educação para os cursos de Arquitetura e Urbanismo) não existe como disciplina obrigatória nos perfis de área e padrões de qualidade no reconhecimento, expansão e avaliação dos cursos de arquitetura e urbanismo do país. Este fato abre precedentes para cursos que possuam poucas disciplinas de conforto ambiental, como levantado por Vianna (2002), que constatou que em $78,7 \%$ dos cursos de conforto ambiental possuem até três disciplinas, destacando-se desta porcentagem, mais da metade, cerca de $40 \%$ com apenas 02 disciplinas.
[6] A Ergonomia não é disciplina obrigatória nos cursos de Arquitetura e Urbanismo. Por este motivo, as maiorias das faculdades não apresentam esta disciplina no seu currículo. Historicamente, a ergonomia faz parte do grupo de disciplinas de conforto ambiental.

[7] Lei n. ${ }^{\circ} 12.378$, de 31 de dezembro de 2010 Regulamenta o exercício da Arquitetura e Urbanismo; cria o Conselho de Arquitetura e Urbanismo do Brasil - CAU/BR e os Conselhos de Arquitetura e Urbanismo dos Estados e do Distrito Federal - CAUs; e dá outras providências. Art. 20 As atividades e atribuições do arquiteto e urbanista: X - do Conforto Ambiental, técnicas referentes ao estabelecimento de condições climáticas, acústicas lumínicas e ergonômicas, para a concepção, organização e construção dos espaços; Disponível em <http://www. planalto.gov.br/ccivil_03/_ ato2007-2010/2010/lei/L12378. htm> 


\section{Cidades e mobilidade: a importância do caminhar}

\begin{abstract}
$A^{s}$ s pessoas se aglomeram em cidades buscando facilitar essa nteração por meio da redução das dificuldades impostas pelos deslocamentos necessários para isso. Segundo Glaeser (2011), "Cidades são a falta de espaço físico entre as pessoas e empresas. Eles são a proximidade, densidade, familiaridade"8 (p.6, tradução nossa). No entanto, essa proximidade leva a uma competição por um espaço exíguo, tanto na realização de atividades quanto nos deslocamentos entre locais nos quais elas são realizadas, o que diminui o benefício das pessoas estarem aglomeradas.
\end{abstract}

Ao contemplarmos a vida nas cidades, seria natural considerar a importância dada às pessoas no espaço urbano e consequentemente no seu papel-chave no planejamento urbano e de áreas edificadas. Pensar nas pessoas ao projetar e planejar as cidades reflete diretamente na qualidade de vida, na escala dos espaços, nas soluções de mobilidade, nas dinâmicas que favorecem a vitalidade, na sustentabilidade e a segurança das áreas urbanas, na valorização dos espaços públicos nas possibilidades de expressão individual e coletiva, na beleza daquilo que pode ser exercido ao nível do observador (LERNER, 2013).

No entanto, apesar de sua importância, a dimensão humana foi desconsiderada por décadas no projeto e no planejamento das cidades, em detrimento a questões que ganharam (e ainda ganham) grande importância e força, como por exemplo, a adaptação das cidades ao aumento do tráfego de automóveis (GEHL, 2014). Quer seja por questões ideológicas de planejamento urbano, quer seja por questões mercadológicas e de tendências arquitetônicas, as cidades acabaram deixando para um segundo plano os espaços comuns, resultando em cidades indiferentes, sem urbanidade.

"Depois de quase cinquenta anos de negligência com a dimensão humana, agora, no início do século XXI temos necessidade urgente e vontade crescente de, mais uma vez criar cidades para pessoas." (GEHL, 2014, p.29)

O espaço reduzido, o ruído, a poluição, o risco de acidentes, os obstáculos, os assaltos, entre outros, são fatores comuns na maioria das grandes cidades da atualidade, e infelizmente fazem com que os pedestres não consigam, na maioria dos casos, efetuar uma atividade primordial, que não os diferem por gênero, faixa etária ou etnia: exercer ato de caminhar. Estas dificuldades, não só proporcionaram uma redução nas oportunidades de explorar 
o espaço urbano, como também reforçaram a setorização dos espaços sociais e culturais das cidades. A falta de dinâmica urbana resultante culmina na falta de suporte para atividades de cultura, arte, lazer, entretenimento, entre outras, além de não fortalecer a economia local.

\begin{abstract}
"As cidades só podem refletir os valores, compromissos e resoluções da sociedade que abrigam. Portanto, o sucesso de uma cidade depende de seus habitantes e do poder público, da prioridade que ambos dão à criação de um ambiente urbano e humano." (ROGERS, 2001, p.16)
\end{abstract}

O século 21 marca o início da era urbana da humanidade. Desde 2007, é estimado que mais de metade da população mundial viva em cidades, e esse número crescerá para $75 \%$ da população até o ano de 2050 (BURDETT E SUDJIC, 2007). No Brasil, estimase que esse percentual seja de $90 \%$ (ONU, 2014). No entanto, as aglomerações humanas com crescimento mais rápido são as megacidades. Estima-se que metade da população urbana viva em cidades com mais de 10 milhões de habitantes (ONU, 2014). É importante destacar que existe uma enorme variedade de níveis de urbanização de espaços que podem ser considerados "áreas urbanas". A ONU explicita em seu documento que não há um senso comum global sobre o que constitui em assentamento urbano. Assim, é considerado como tal a partir da combinação de uma ou mais dessas seguintes características: uma quantia mínima de habitantes, densidade populacional, proporção da população empregada em setores não rurais, a presença de infraestrutura básica urbana (abastecimento de energia e água, escoamento de esgoto e pavimentação de vias), e a presença de serviços ligados à saúde e educação.

Um exemplo é a metrópole de São Paulo, a maior e mais importante aglomeração urbana do Brasil e está entre as dez maiores áreas urbanas do mundo (ONU, 2012). Seus 20 milhões de habitantes são responsáveis por $10 \%$ da população brasileira e geram $18 \%$ do PIB brasileiro. A capital do Estado tem $6 \%$ da população brasileira e gera $12 \%$ do PIB brasileiro (IBGE, 2014). No entanto, a mobilidade ${ }^{9}$ espacial na metrópole atualmente apresenta baixa qualidade e alto impacto ambiental: estima-se que os prejuízos em produtividade e saúde dos atuais níveis de congestionamento na metrópole chegue a $1 \%$ do P IB brasileiro anualmente (CINTRA, 2014).

O tecido urbano de São Paulo está marcado por uma intensa transformação, em decorrência de seu acelerado desenvolvimento. Hoje, a cidade mostra um grande desequilíbrio da distribuição da densidade populacional, cujo principal reflexo é o problema da mobilidade urbana. De certa forma, muito tem se empenhado na
[9] Mobilidade pode ser sintetizada na comodidade do deslocamento individual dentro do espaço urbano. Trata-se de um conceito múltiplo, que envolve não apenas variáveis físicas e quantitativas, mas também questões sociais, econômicas e políticas (VIANNA JÚNIOR, 2000). Podendo ser definida como, condições necessárias para o deslocamento das pessoas. Ou seja, ter mobilidade é conseguir se locomover com facilidade de um lugar para o outro, independentemente do tipo de veículo utilizado, de vias públicas e da infraestrutura disponível. (SCARINGELLA, 2013). 
garantia da acessibilidade das edificações, o que já não ocorre com os espaços urbanos (HARRIS, 2014).

Entende-se que, na cidade de São Paulo, são muitas as áreas em que o simples ato de caminhar é comprometido pelas condições precárias de acessibilidade e qualidade ambiental, no que tange ao conforto (ou stress) térmico, acústico e qualidade do ar, no entanto, o aumento dos níveis de adensamento não trará benefícios sem que haja uma mudança modal na metrópole. Para isso, o sistema de transporte coletivo deve ser planejado para o transporte intermodal, com locação de bicicletas, veículos de pequeno porte para pessoas com mobilidade reduzida nas estações, e estacionamento nas estações mais periféricas, e principalmente incentivando e dando condições para o caminhar.

De acordo com Eugênio Queiroga (QUEIROGA, 2014), questões relacionadas a sistemas de mobilidade de menor impacto, bem como a criação de espaços adequados para a circulação de pedestres e convívio público devem levar em conta as análises e as propostas de qualificação de sistemas de espaços livres urbanos (SELs).

Considerando tais premissas, nota-se que os percursos pedonais urbanos são fundamentais para garantia da microacessibilidade e mobilidade no meio urbano.

Identificando esta necessidade, a Organização das Nações Unidas, elencou, no documento "Diretrizes Internacionais para Planejamento Urbano e Territorial", as seguintes recomendações focadas no caminhar:

\begin{abstract}
"Autoridades locais: usar o planejamento urbano e territorial para reservar um espaço adequado para ruas, visando desenvolver uma rede de ruas seguras, confortáveis e eficientes, permitindo um alto nível de conectividade e incentivando o transporte não motorizado para melhorar a produtividade econômica e facilitar o desenvolvimento econômico local; (...) criar ruas e incentivar caminhadas, o uso de transporte não motorizado e do transporte público e plantar árvores para fornecer sombra e absorver o dióxido de carbono." (ONU-HABITAT, 2015)
\end{abstract}

Do ponto de vista da qualidade ambiental urbana, entendese que tecnicamente gabarito médio, baixo ou alto não implica diretamente em melhor ou pior qualidade. É de uma combinação de fatores construtivos que vai resultar a qualidade ambiental do espaço da cidade, como orientação solar dos edifícios, recuos e forma, combinados ao tratamento do espaço aberto e à importância dada a vegetação, pela influência desses parâmetros no desempenho de variáveis ambientais. 
Washburn (2013) observa que atualmente, para tornar as cidades "habitáveis" deve haver um grande esforço para que o desenho urbano, com respaldo da integração política e econômica, consiga esta transformação. Neste processo, ressalta-se que o desenho urbano possui o poder de integrar ou não as comunidades, e consequentemente proporcionar a possibilidade de sobrevivência das cidades. Ainda observa-se que os cidadãos comuns, possuem uma grande responsabilidade neste processo uma vez que são agentes de transformação diretos na conquista de cidades mais eficientes, equitativas, seguras e com experiências mais enriquecedoras.

Porúltimo, mas não menos importante, é a relação entre as questões técnicas relacionadas ao conforto pedonal com a experiência subjetiva do usuário em sua prática do caminhar. Francesco Careri (CARERI, 2013) enfatiza a importância do caminhar como prática estética: incentiva o percurso exploratório como metodologia experimental de investigação dos territórios urbanos. Segundo o autor, esta prática leva a uma valorização do ser humano na cidade, com a inserção da escala do corpo na escala da cidade. 


\section{Em busca do conforto ao caminhar:}

a ergonomia e a avaliação dos espaços urbanos

J acobs (2009) destaca que as calçadas possuem uma complexidade maior que o seu caráter de passagem de pedestres, e éjustamente esta heterogeneidade que garante a segurança e a liberdade e a vida das cidades.

"A calçada por si só não é nada. É uma abstração. Ela só significa alguma coisa junto com os edifícios e os outros usos limítrofes a ela ou a calçadas próximas. (...) As ruas e as calçadas, principais locais públicos de uma cidade, são seus órgãos mais vitais. Ao pensar numa cidade, o que lhe vem à cabeça? Suas ruas. Se as ruas de uma cidade parecerem interessantes, a cidade parecerá interessante; se elas parecerem monótonas, a cidade parecerá monótona." (JACOBS, 2009)

Gehl (2013) identifica um padrão dentro da complexidade de atividades de uma calçada, colocando-as em categorias de acordo com a sua escala e o seu grau de necessidade. A primeira delas diz respeito às atividades obrigatoriamente necessárias, ou seja, aquelas que as pessoas geralmente têm que fazer e que acontecem sob qualquer condição como, por exemplo, ir trabalhar ou ir à escola. Do outro lado dessa escala se encontram as atividades facultativas, as quais se relacionam com atividades prazerosas e recreativas como contemplar a cidade ou o local sem o caráter de ser apenas transitório. Segundo Gehl, esse tipo de atividade é prérequisito para uma boa qualidade urbana já que se as condições ao ar livre forem boas, as pessoas se entregam para além das atividades necessárias e assim, o número de atividades opcionais cresce. Outro aspecto a se destacar nesse contexto é em relação a outros fatores que influenciam nessas atividades. Uma dela é a influência do clima do local, já que ele é um importante fator para o alcance e o caráter das atividades ao ar livre. Se condições de clima fossem muito extremas no meio urbano, as atividades diminuiriam significativamente. Além desse aspecto, a qualidade física não apenas da calçada, mas de todo conjunto urbano é de extrema importância. O Planejamento e o projeto urbano podem e devem ser usados para influenciar o alcance e o caráter das atividades ao ar livre.

Esse convite do meio físico pode estimular o pedestre a exercer outras atividades para além das necessárias, incluindo questões de proteção, segurança, espaço razoável, mobiliário e qualidade 
visual. Cabe também ressaltar que esse importante convite do meio construído pode fazer com que as pessoas participem de uma vida urbana mais versátil e variada de forma mais ativa. (GEHL, 2013). A partir desse contexto, pode-se afirmar que as calçadas trazem questões muito além do simples caminhar.

O ponto central é a percepção espacial do pedestre em relação ao próprio ambiente que pode a vir estimulá-lo sensorialmente. Dessa maneira, o estudo das calçadas abrange duas grandes esferas que se correlacionam: o conforto ambiental, com enfoque da ergonomia e a percepção espacial.

Ao relacionar a Ergonomia com morfologia urbana física, podese analisar o espaço diante de uma visão que envolve não só a identificação do gabarito urbano, mas também a identificação de obstáculos fixos, obstáculos móveis e de questões de conforto ambiental e segurança humana. Por obstáculos fixos, entendese desde aspectos que envolvem a declividade e inclinação da via até as obstruções propriamente ditas como orelhões, lixeiras, pontos de ônibus. Já os obstáculos móveis abrangem o conjunto de impedimentos de caráter temporário como lixos, vendedores ambulantes e veículos. Partindo-se dos obstáculos citados, pode-se destacar a importância do conforto e da segurança nas atividades humanas. Inúmeros fatores influenciam nesses dois aspectos desde questões climáticas, passando por questões sensoriais até chegar à percepção espacial propriamente dita.

Muitas variáveis influenciam na percepção espacial dos humanos. Em se tratando das calçadas, é importante notar que é um ambiente poli dimensional já que não podem ser consideradas apenas como planos meramente er uma experiência multissensorial onde desde as limitações visuais existentes até o tato com a materialidade do revestimento do piso são de extrema importância.

Kevin Lynch (LYNCH, 2008), em seu livro "A Imagem da Cidade", coloca que o ser humano não é apenas espectador do ambiente, mas divide a cena com todos os outros participantes. Assim, a percepção do ambiente (no caso, os espaços livres urbanos) não é contínua, e sim, parcial e fragmentária. Além disso, a relação com a cidade pode ter laços com nossa memória e significados, havendo certamente uma ação de nossos sentidos na interpretação de um determinado espaço. Ainda, Lynch destaca a importância dos nossos sentidos na identificação dos ambientes, principalmente a pista visual e olfativa. Lynch aponta que, sem esta pista oferecida por nossos sentidos, o ser humano sente-se perdido.

O urbanista americano Jeff Speck, baseia inteiramente o seu livro "Cidade Caminhável" sobre o passear a pé pelas ruas. Não apenas Speck (2016), mas também outros autores concordam e mostram 
que o caminhar é o meio mais direto em que pessoas e cidades se relacionam. Através da qualidade de vida urbana denominada "caminhabilidade" o urbanista mostra que o envolvimento com a vida civil, ou seja, a cidadania é algo físico, e que cresce a partir dos encontros da vida no chão urbano (SPECK, 2016).

Michael Southworth (2005) define o que seria a "andabilidade"10 "quando o ambiente construído apoia e encoraja o caminhar e promove conforto e segurança ao pedestre, conectando pessoas em diferentes destinos dentro de um tempo e esforço razoável, e oferece interesse visual no percurso através da rede". Este conceito, ressalta o autor, pressupõe, a interligação à diferentes meios de transporte público, reduzindo a dependência do carro. Segundo Southworth (2005) a "andabilidade" é a base de uma "cidade sustentável" e de um meio de transporte mais democrático, já que todos somos pedestres.

Jeff Speck (SPECK, 2016), estabelece dez passos para garantir a caminhabilidade, ou, "walkability", em seu termo original. Dois destes passos, estão relacionados ao conforto ao caminhar. O primeiro deles, segundo Speck, consiste nas "formas dos espaços": o ser humano necessita inatamente praticar duas atividades: prospectar e se refugiar. Assim, no meio urbano construído, o ser humano deve poder praticar com autonomia estas duas atividades, de forma a sentir-se confortável. Neste sentido, Speck coloca que a vitalidade da forma urbana é um dos elementos que afeta diretamente nosso conforto. Acrescenta ainda, que os fatores climáticos impactam menos o usuário que o precário desenho das nossas vias. Na sequência, o segundo passo consistiria em "plantar árvores". Segundo eles, colocar mais árvores nas cidades impacta diretamente a caminhabilidade. Por fim, comenta a dificuldade de implementar uma arborização urbana eficiente em detrimento de discursos sobre visibilidade e segurança ao dirigir. Ou seja, mais uma vez, os interesses dos automóveis se sobrepondo aos do pedestre.

Analisando a questão do transporte e a forma urbana, Rode e Floater (ROADE, FLOATER, 2014) defendem a necessidade de se criar acessibilidade com base na proximidade física. Para isso, colocam a importância que se deve dar ao "planejamento, desenho urbano, construção e gestão da condição local, na escala humana". Fazendo uma analogia direta, a melhoria dos percursos pedonais urbanos, em termos gerais e ou de conforto do pedestre, está intrinsecamente relacionada a novas estratégias de desenho urbano, que evidenciem a escala do caminhar na cidade. Ou seja, o debate é amplo, e depende também de políticas públicas e governanças. 
Segundo a NBR 9050, A calçada deve ser definida pela fluidez, conforto e segurança. Para garantir a fluidez, a calçada precisa ter uma largura compatível com seu fluxo de pedestres, para que estes consigam andar em uma velocidade constante. Uma calçada confortável e segura deve ter um piso adequado e quase plano, deve ser larga e arborizada e não deve possuir obstáculos no espaço livre, evitando assim a possibilidade de quedas e tropeços.

Não só na cidade de São Paulo, mas na grande maioria das cidades do Brasil, a calçada não era responsabilidade do poder público, o que gerava problemas de manutenção, diferenças de piso e presença de obstáculos. Em 2005 o decreto no 45.094 estabeleceu o novo padrão arquitetônico para as calçadas da cidade de São Paulo, tendo como base a norma de acessibilidade NBR 9050.

Apesar do cenário desfavorável, a Associação Nacional de Transportes Públicos (ANTP) afirma que a divisão modal de viagens feitas em cidades do Brasil monstra que 36\% da população se desloca a pé até os seus destinos. Este elevado percentual denota a importância de se desenvolver ferramentas para analisar a qualidade de espaços urbanos sob o ponto de vista do pedestre.

Uma importante referência é o "Índice de Caminhabilidade" (ITDP, 2016), criado no final de 2016, fruto de uma parceria entre ITDP Brasil (Instituto de Políticas de Transporte e Desenvolvimento) e o Instituto Rio Patrimônio da Humanidade (IRPH), com a colaboração da Publica Arquitetos.

Este documento tem por objetivo ensinar o passo a passo para aplicação de uma ferramenta capaz de "avaliar as condições do espaço urbano e monitorar o impacto de ações de qualificação do espaço público, indicando em que medida favorecem ou não os deslocamentos a pé." O índice é composto por 21 indicadores agrupados em seis diferentes categorias (fig. 1). Cada uma dela incorpora uma dimensão da experiência do caminhar.

A avaliação final de um segmento de calçada, por meio da ferramenta, consiste em uma média aritmética destas seis categorías, variando de 0 a 3 pontos, conforme imagem a seguir (Figura 4): 

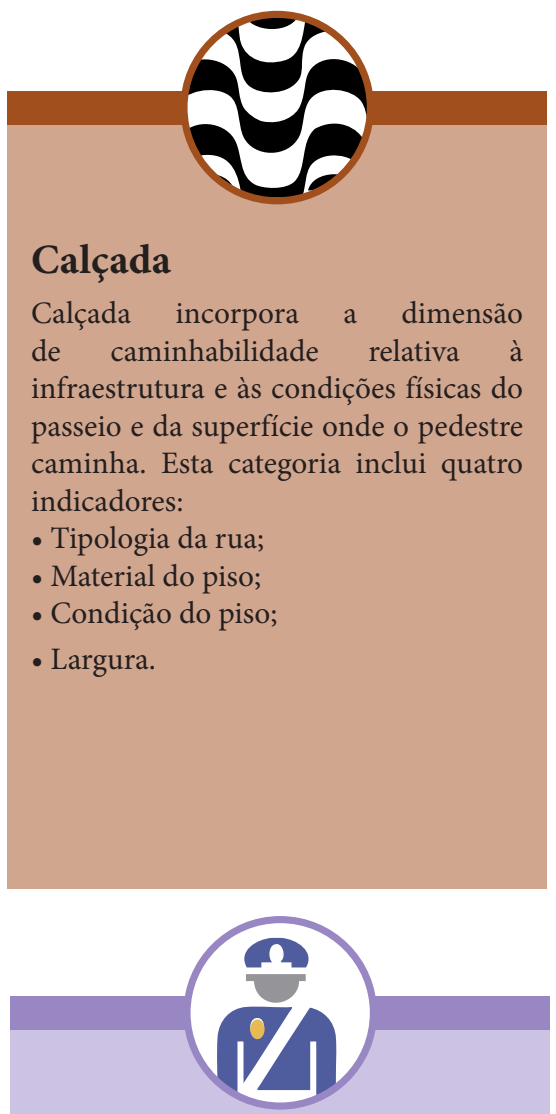

\section{Segurança Pública}

A Segurança Pública, ou seguridade, é um tema recorrente nas discussões sobre utilização da rua e outros espaços públicos, especialmente em países com profundas desigualdades sociais como o Brasil. Pesquisadoresix têm explorado a influência do desenho urbano e das edificações no número de ocorrências e na sensação de segurança transmitida aos pedestres desde a década de 1960. A categoria Segurança Pública é composta por três indicadores relativos ao tema. Outros indicadores comumente associados à segurança no espaço público, como transparência das fachadas, encontram-se contemplados na categoria Atração.

- Iluminação;

- Fluxo de pedestres diurno e noturno;

- Incidência de crimes.

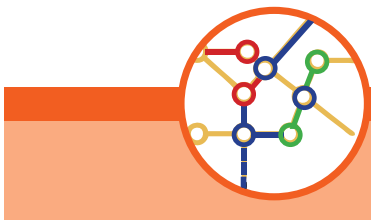

\section{Mobilidade}

Mobilidade está relacionada à disponibilidade e acessibilidade a formas de transporte sustentável, nominalmente transporte de média e alta capacidade e infraestrutura cicloviária. Mede também a permeabilidade da malha urbana através do indicador Dimensão das Quadras.

Esta categoria inclui três indicadores:

- Dimensão das quadras;

- Distância do transporte de média e alta capacidade;

- Rede cicloviária.

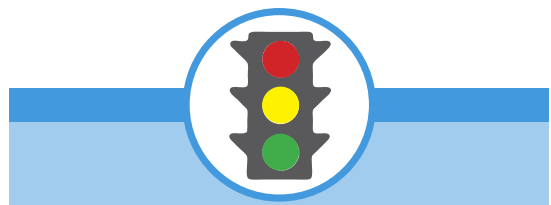

\section{Segurança Viária}

Esta categoria agrupa indicadores referentes à segurança de pedestres em relação ao tráfego de veículos motorizados, assim como itens relacionados à acessibilidade universal. Esses indicadores têm grande importância na avaliação de condições de caminhabilidade, pois estão relacionados a riscos de colisões e fatalidades. Esta categoria inclui três indicadores:

- Travessias;

- Velocidade máxima permitida de veículos motorizados;

- Atropelamentos.

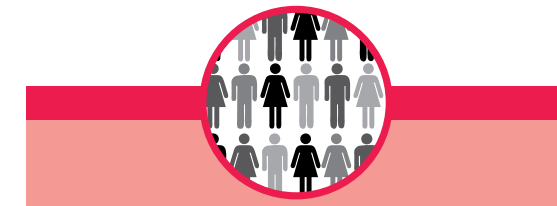

\section{Atração}

Esta categoria inclui indicadores relacionados a características de uso do solo que influenciam a atratividade do deslocamento para o pedestre. Eles avaliam atributos das edificações e outras condições que podem ter um impacto decisivo na intensidade do uso das rotas de pedestres e na sua distribuição ao longo do dia ou semana. Esta categoria inclui quatro indicadores:

- Fachadas fisicamente permeáveis;

- Fachadas visualmente permeáveis;

- Usos mistos;

- Uso público diurno e noturno.

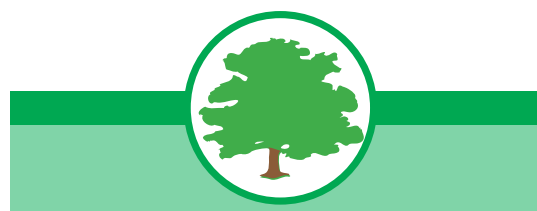

\section{Ambiente}

Esta categoria agrupa indicadores relacionados a aspectos ambientais que possam afetar as condições de caminhabilidade de um espaço urbano. Esses indicadores estão relacionados a aspectos de conforto (como, por exemplo, sombra e abrigo) e a condições ambientais tais como qualidade do ar. Os quatro indicadores avaliados são:

- Sombra e abrigo;

- Qualidade do ar

- Poluição sonora;

- Coleta de lixo e limpeza.
Figura 4 (Superior): Seis categorias e 21 indicadores da ferramenta de cálculo "Índice de Caminhabilidade" proposta pelo ITDP. Fonte: ITDP, 2016.

Tabela 1 (Ao lado): Sistema de pontuação final da ferramenta, a partir de média aritmética dos indicadores avaliados. Fonte: ITDP, 2016.

\section{Pontução 3 Pontuação 2 a 2,9 Pontuação 1 a 1,9 Pontuação 0 a 0,9}

\begin{tabular}{|c|c|c|c|}
\hline ÓTIMO & BOM & ACEITÁVEL & INSUFICIENTE \\
\hline $\begin{array}{l}\text { Manutenção e } \\
\text { aperfeiçoamento }\end{array}$ & $\begin{array}{c}\text { Intervenção } \\
\text { desejável , ação a } \\
\text { médio prazo }\end{array}$ & $\begin{array}{c}\text { Intervenção } \\
\text { prioritária, ação } \\
\text { a curto prazo }\end{array}$ & $\begin{array}{c}\text { Intervenção } \\
\text { prioritária , ação } \\
\text { imediata }\end{array}$ \\
\hline
\end{tabular}


Desde o dia $1^{\circ}$ de janeiro de $2016^{11}$, com a entrada em vigor da Lei Brasileira de Inclusão (LBI), a responsabilidade de adequação e manutenção das calçadas passa a ser responsabilidade do poder público e não mais do proprietário do imóvel, o que traz mais força às ações públicas neste setor.

Para organizar a calçada, o decreto a divide em três faixas.

1. Faixa de Serviço: destinada a obstáculos, como árvores, postes, lixeiras, rampas de acesso a veículos e cadeirantes, bancos, telefones etc.

2. Faixa Livre: destinada exclusivamente à circulação de pedestres, esta faixa deve esta livre de qualquer obstáculo fixo ou temporário, além de qualquer desnível, devendo permitir um fluxo contínuo. Esta faixa deve ter largura mínima de 1,2m, variando conforme o volume de pedestres, e deve ser contínua, sem qualquer emenda, reparo ou fissura.

3. Faixa de Acesso: localizada em frente aos imóveis, esta faixa serve de apoio à propriedade, podendo ter vegetação, rampas, toldos além de mesas de bar e floreiras.

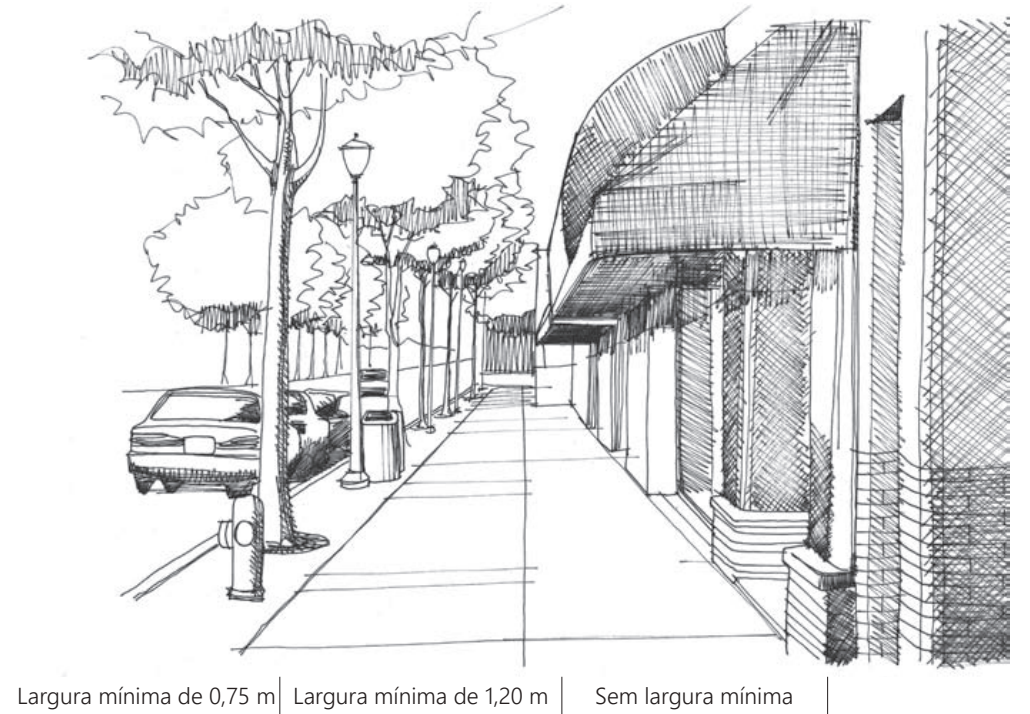

Frequentemente, são necessáriasintervenções nos espaços públicos já existentes, visando melhorar seu desempenho e adequá-los para o atendimento de novas demandas ou de demandas já existentes, que não são respondidas de forma adequada. Muitas vezes, essas intervenções são fundamentais para garantir a acessibilidade e melhorar as condições de mobilidade de determinada área urbana. Isso exige um prévio entendimento das características do lugar e das atividades nele desenvolvidas, para que os projetos respondam às reais necessidades dos usuários. Grande parte desse entendimento provém das avaliações de ergonomia, as quais exigem um método adequado para o levantamento de dados.
Figura 5: Organização das calçadas segundo Programa Passeio Livre. Fonte: Cartilha Programa Passeio Livre da Prefeitura de São Paulo.

[11] Sancionada em julho do ano passado a Lei 13.146 passou a ser conhecida como Lei Brasileira de Inclusão da Pessoa com Deficiência. http://www.planalto.gov.br/ ccivil_03/_Ato2015-2018/2015/ Lei/L13146.htm 
Apesar de as calçadas proporcionarem hábitos saudáveis e ativos, elas não vêm sem seus desafios: é mais fácil projetar calçadas em bairros novos do que modificá-las de forma retroativa em um contexto já construído. No entanto, é fundamental encontrar a distribuição apropriada de espaço entre usos competitivos dentro do direito de passagem, e garantir que as calçadas sejam concebidas e mantidas de forma adequada para permitir a utilização segura e convidativa os pedestres.

Estudos mostram como as pessoas se sentem inseguras nas vias em suas comunidades - falta de calçadas, falta de iluminação e muito poucas faixas de pedestres. Esses problemas com o ambiente construído afastam as pessoas das caminhadas e de bicicletas e as leva ao trânsito (Washburn, 2013).

É muito importante aproveitar a LBI - Lei Brasileira de Inclusão, como momento de reforçar e estabelecer definitivamente critérios para uma cidade mais eficiente, equitativa, segura e agradável para todos os cidadãos. 


\section{Quadro resumo}

- O ensino do Conforto Ambiental obteve um expressivo impulso devido ao contexto mundial global de necessidade de redução dos impactos ambientais.

- A concepção do ensino de conforto ambiental em disciplinas estanques prejudica o entendimento destes fatores na espacialidade do projeto.

- A ergonomia trabalha com a relação da Arquitetura e o Meio através das sensações e estímulos, é desejável que este processo de avaliação traga a possibilidade de interação dos fatores físicos, ambientais, psicológicos e culturais.

- Um dos aspectos mais essenciais no processo da avaliação do conforto ambiental e a percepção espacial é a compreensão de como os indivíduos percebem, assimilam e agem a partir de informações que captam no ambiente à sua volta.

- As alterações dos significados de conforto ao longo do século passado trouxeram significativas implicações na gestão ambiental interna e demanda de energia dos edifícios.

- Até que ponto os edifícios e as cidades respondem às demandas reais de conforto ou apenas refletem convenções sociais e culturais do momento?

- Os edifícios de menor impacto ambiental exigem um envolvimento mais proativo entre ocupante, edifício e ambiente, e consequentemente reflete $o$ número de técnicas com soluções passivas e se o emprego de técnicas ativas realmente é imprescindível.

- O conforto adaptativo, além de gerar grande economia de energia, também gera maior qualidade ambiental.

- Psicologia Ambiental e Ergonomia do Ambiente, independentemente das classificações existentes e abordagens dadas, são importantes áreas que abordam a percepção do usuário no ambiente em que se encontram.

- O termo percepção corresponde à maneira como o usuário experimenta o espaço, tanto seus aspectos físicos como sociais, culturais e históricos.

- A Ergonomia reforça a sua especificidade à medida que considere mais do que somente as "propriedades do homem", ou seja, entenda como o homem usa as suas propriedades em termos da sua história, seus desejos, motivos, experiências e anseios individuais.

- Entender o "trabalho" como qualquer ação do homem no meio em que se encontra trouxe a real dimensão da ERGONOMIA.

- A Ergonomia na Arquitetura tem como objeto o homem no espaço.

- A ergonomia, a partir de seus quatro fatores estruturadores: os psicológicos, os socioculturais, os ambientais e os físicos, embasa ações projetuais que visam conforto.

- Apesar da existência de métodos de conforto ambiental amplamente consolidados nas áreas de conforto térmico, acústico e luminoso, na área de ergonomia, observa-se uma grande quantidade de métodos em fase de amadurecimento.

- Todas as áreas que fazem parte do conforto ambiental, térmica, acústica, iluminação natural e artificial, e ergonomia devem ser avaliadas em conjunto, dentro de um contexto que adequem todas as possíveis interfaces com 0 projeto procurando estabelecer a relação destas áreas e o comportamento do usuário.

- A abordagem convencional das variáveis de conforto no projeto aprofundam o detalhamento dos aspectos relacionados com os fatores físicos, em detrimento aos aspectos sócio culturais, psicológicos e ambientais.

- A ergonomia, juntamente com a Ergonomia, com o seu caráter integrador deve ser resgatado no processo de projeto, e nas análises de desempenho ambiental, não só para auxiliar um resultado mais adequado, mas também para auxiliar na transformação necessária de edifícios e de cidades em ambientes de melhor desempenho e qualidade ambiental 
- A avaliação do comportamento do usuário merece ser enfatizada como uma importante ferramenta da APO.

- A FAUUSP - Faculdade de Arquitetura e Urbanismo da Universidade de São Paulo mostra um papel importante nas pesquisas de APO no Brasil.

- A Ergonomia ao ser entendida de forma mais abrangente e integrada com os seus elementos estruturadores: físico, ambiental, psicológico e cultural, se une à Psicologia Ambiental podendo contribuir de maneira efetiva nas soluções adotadas no ambiente construído.

- Esta tese procura contribuir e auxiliar para que a ergonomia seja entendida de forma abrangente e integrada não só com o conforto ambiental, mas também nas etapas de projeto através dos fatores estruturadores: físico, ambiental, psicológico e cultural.

- A dimensão humana foi deixada em um segundo plano por décadas no projeto e no planejamento das cidades, em detrimento a questões que ganharam (e ainda ganham) importância e força, como por exemplo, a adaptação das cidades ao aumento do tráfego de automóveis.

- O espaço reduzido, o ruído, a poluição, o risco de acidentes, os obstáculos, os assaltos, entre outros, são fatores comuns na maioria das grandes cidades da atualidade, fazem com que os pedestres não consigam efetuar uma atividade primordial, que não os diferem por gênero, faixa etária ou etnia: exercer ato de caminhar.

- Ao relacionar a Ergonomia com morfologia urbana física, pode-se analisar o espaço diante de uma visão que envolve não só a identificação do gabarito urbano, mas também a identificação de obstáculos fixos, obstáculos móveis e de questões de conforto ambiental e segurança humana.

- A "andabilidade" "quando o ambiente construído apoia e encoraja o caminhar e promove conforto e segurança ao pedestre, conectando pessoas em diferentes destinos dentro de um tempo e esforço razoável, e oferece interesse visual no percurso através da rede".

- Southworth e Pozueta definem e propõem atributos indispensáveis para obter uma cidade com atrativos para o pedestre. 
O objetivo deste capítulo é apresentar métodos de avaliação ergonômica que considerem principalmente a percepção do usuário e que tenham como foco o ambiente urbano.

Estes métodos apresentados procuram avaliar o conforto urbano do pedestre, sob o enfoque ergonômico, ao caminhar, serviram de embasamento para o método proposto na minha tese.

De acordo com a ótica da ergonomia e dos pedestres nos espaços urbanos, são apresentados os métodos: Highway Capacity Manual - HCM (2000); Southworth (2005), Pozueta (2005) e o Active Design, do Departamento de Planejamento de Nova lorque (2013). 


\title{
Método 1: \\ Fluxo de pedestres
}

\begin{abstract}
Com o objetivo de avaliar os fatores que influenciam na qualidade de um deslocamento a pé, alguns pesquisadores desenvolveram métodos para este fim. Apesar de questionável, alguns destes métodos avaliam de forma isolada alguns destes fatores, como é o caso do Highway Capacity Model (2000) que avalia o nível de serviço nas calçadas, considerando o critério de capacidade: fluxo de pedestres que atravessam uma determinada seção de calçada no intervalo de tempo de um minuto (CARVALHO 2006).

O método aqui apresentado, teve por objetivo o entendimento dos fatores envolvidos para o cálculo do fluxo dos pedestres, com foco na aplicação posterior nas análises de percepção do usuário. Desta forma, apesar de se mostrar isolado dentro do contexto anteriormente apresentado nesta tese, procurou-se entender como o fluxo pode ser calculado, como pode afetar o dimensionamento da calçada, e poderá influenciar os outros parâmetros de análise selecionados.
\end{abstract}

Dentro deste contexto, utilizou-se então, a tese de doutorado de Carvalho (2006) que elaborou um esquema indicativo de espaçamento de pedestres e taxa de fluxo segundo o Highway Capacity Manual (2000). O Manual apresenta seis níveis de serviço que variam de acordo com o número de pedestres por minuto por metro, a liberdade de movimento e velocidade vão diminuindo com o aumento do fluxo.

Na aplicação proposta, utiliza-se os níveis de serviço de Carvalho (2006) e aplica-se para cálculo da dimensão da calçada a equação sugerida na NBR 9050 (2015). Desta forma, o K é o utilizado de acordo com o nível de serviço apresentado:

$$
L=F / K+\sum i \geq 1,20
$$

onde:

L é a largura da faixa livre;

F é o fluxo de pedestres estimado ou medido nos horários de pico (pedestres por minuto por metro);

$\mathrm{K}=25$ pedestres por minuto;

$\sum$ i é o somatório dos valores adicionais relativos aos fatores 
de impedância.

Os valores adicionais relativos a fatores de impedância (i) são:

a) 0,45m junto a vitrines ou comércio no alinhamento;

b) 0,25m junto a mobiliário urbano;

c) 0,25m junto à entrada de edificações no alinhamento.

Nivel de Serviço A

Area $f$ ped $>5,6 \mathrm{~m}^{2} /$ ped

Taxa de fluxo $\leq 16 \mathrm{ped} / \mathrm{min} / \mathrm{m}$

Năo há interferéncia de outros

pedestres

Nivel de Serviço B

Área $/$ ped $>3,7-5,6 \mathrm{~m}^{2} /$ ped

Taxa de fluxo $>16-23 \mathrm{ped} / \mathrm{min} / \mathrm{m}$

Liberdade de movimento e escolha da

velocidade de caminhada

Nivel de Serviço C

Área $/$ ped $>2,2-3,7 \mathrm{~m}^{2} /$ ped

Taxa de fluxo $>23-33 \mathrm{ped} / \mathrm{min} / \mathrm{m}$

Velocidades menores, há poucos

conflitos

Nivel de Serviço D

Area $/$ ped $>1,4-2,2 \mathrm{~m}^{2} /$ ped

Taxa de fluxo $>33-49 \mathrm{ped} / \mathrm{min} / \mathrm{m}$

Movimentos com menor liberdade,

causando mudança na velocidade

Nivel de Serviço $E$

- Área / ped >0,75-1,4 $\mathrm{m}^{2} /$ ped

Taxa de fluxo $>49-75 \mathrm{ped} / \mathrm{min} / \mathrm{m}$

O volume de pedestres se aproxima da

capacidade limite da calçada; restriçōes

maiores aos movimentos

Nivel de Serviço F

Area / ped $\leq 0,75 \mathrm{~m}^{\alpha} /$ ped

Taxa de fluxo é variada ped $/ \mathrm{min} / \mathrm{m}$;

velocidade de severamente restrita; fluxo

esporádico e Instável; congestionamento
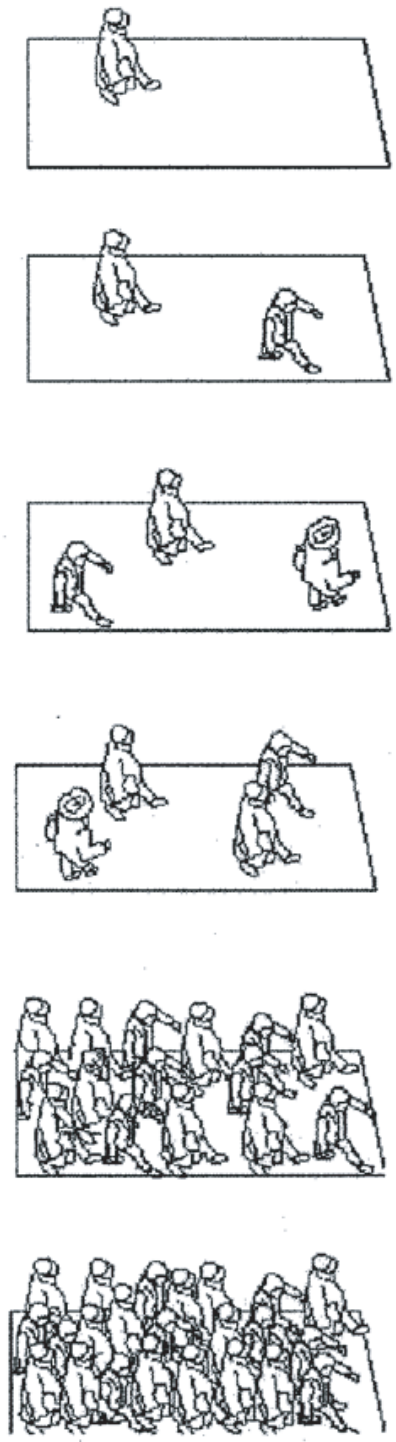
Método 2:

Atrativos para o pedestres - Southworth

Em Designing the Walkable City, Southworth (2005) define Ee propõe atributos indispensáveis para obter uma cidade com atrativos para o pedestre. Apesar de não sugerir critérios específicos para estes atributos, foram utilizados nos trabalhos que embasaram os métodos de referência e posteriormente o método proposto:

\section{CONECTIVIDADE}

- Calçadas e outros caminhos aos pedestres

- Continuidade sem barreiras significantes

- Quarteirões menores, gerando mais intersecções.

\section{LIGAÇÃO COM OUTROS MEIOS}

- Ligação com o macro urbano

- Distâncias razoáveis (10 a 20 minutos)

3. USO MISTO DO SOLO

- Serviços acessíveis de 10 a 20 minutos

- Lojas, café, banco, lavanderia, mercado, creche, fitness, escola, livraria, parque, etc.

\section{SEGURANÇA}

- Reduzir a velocidade dos carros a partir de diferentes soluções

\section{QUALIDADE DO CAMINHO}

- Conforto e segurança à qualquer usuário

\section{CONTEXTO DO CAMINHO}

- Engajar o interesse do usuário

- Desenho urbano, paisagismo, arquitetura, etc.

- Ruas de escala do pedestre

O objetivo de alcançar a "andabilidade" em todos os bairros e criar políticas e planejamento para manter o ambiente das ruas do pedestre é, segundo Southworth (2005) a garantia do "meio de transporte" mais utilizado e mais democrático. 
Método 3:

Transporte alternativo - Pozueta

Dozueta (2005) busca desmitificar o uso do carro como melhor opção de locomoção nas grandes cidades atualmente. Segundo o autor seu uso só resulta em consequências negativas, tanto por questões ambientais, como na própria eficácia, que é perdida ao gerar congestionamento. Por ter uma alta ocupação de solo por passageiro, quanto maior o uso de carro, maior o congestionamento e, por tanto, maior o tempo de viagem. Além disso, causa danos ambientais, tornando a rua perigosa e desagradável ao pedestre. A redução do uso do carro é, então, uma questão que abrange três âmbitos distintos: ambiental (gera poluição), social (o sistema de transporte é mais eficiente quando é para todos) e técnica (congestionamento aumenta tempo de viagem). É necessária, então, uma administração da demanda por transporte ("transport demand management'), que deve agir através de abordagens na própria demanda por mobilidade (promover trabalho e estudo em casa, redução dos dias úteis, etc), na promoção de meios de transportes alternativos e na otimização do uso de infraestrutura existente.

A mobilidade também é intrínseca ao modelo urbano na qual está inserida. Uma "mobilidade sustentável" deve estar associada à um modelo urbano compacto, de uso misto e denso, além da morfologia de vias. A promoção do transporte alternativo, portanto, está ligada ao desenho de vias e no planejamento do acesso ao transporte. É preciso desenhar algo que se adeque e se adapte as formas e polaridades do sistema já estabelecido, ao potencializar a localização das estações próximas aos locais de emprego e as altas densidades, além de comércio, serviço e espaço público de qualidade. Neste contexto, Pozueta (2005) sugere:

\section{PROMOÇÃO DO DESLOCAMENTO EM BICICLETA}

- Melhor meio para medias distancias (7 a $10 \mathrm{~km}$ )

- Desenvolver itinerários eficazes de ciclofaixas - disposição espacial unindo pontos de máxima atração de viagens e facilitando o intercambio modal

- Educar os condutores e conscientizar a população das vantagens da bicicleta;

- vias diretas, confortáveis, atrativas e seguras;

- estacionamentos de bicicleta

- Os tipos de sinalização e vias que abrangem as bicicletas são:

- ciclovias (bicicleta isolada);

- via bicicleta e pedestre (risco ao pedestre); 
- ciclofaixa (faixa destinada a bicicleta em via de transito motorizado);

- faixa destinada a bicicleta e ônibus (muito perigosa ao ciclista);

- via sinalizada a direita para bicicleta (divide espaco com

o carro).

\section{PROMOÇÃO DO DESLOCAMENTO A PÉ}

- O percurso deve ser:

- funcional (direto ao atrativo)

- seguro (aos carros e a roubos)

- confortável (seguir NBR 9050)

- atrativo

- Acalmar o tráfego de carros com obstáculos físicos:

- para manter $20 \mathrm{~km} / \mathrm{h}$, distância entre obstáculos de 25 metros; para $30 \mathrm{~km} / \mathrm{h}$, a cada 75 metros

- lombadas, valetas

- estreitamento de vias

- mudanças no traçado

- tartaruga

- obstáculos nos cruzamentos

- Desestímulo ao estacionamento e veículo privado

- diminuir a disponibilidade de vagas, com maior cobrança por duração

- estabelecer número máximo de vagas em edifício de serviços

- promover estacionamento dissuasório, que dá acesso ao transporte público e carona

Por serem complementares, a aplicação dos métodos de referência 02 e 03 foi realizada conjuntamente dentro de alguns critérios estabelecidos para os atributos sugeridos considerados relevantes nesta tese. Desta forma após a definição dos critérios sugeriu-se uma forma de aferição com fichas e escalas gráficas como poderá ser visto no capítulo seguinte. 
Método 4:

Sala da calçada - Active Design

$\mathrm{O}$ Departamento de Planejamento de Nova lorque (CIDADE DE NOVA IORQUE, 2013) ao compor um documento exclusivo para as calçadas chamado de Active Design Guidelines explicita esse fato destacado anteriormente e define certas escalas a serem trabalhadas nesse cenário. Além da escala humana propriamente dita, o documento destaca mais outras duas escalas que influenciam no conforto e na segurança do caminhar pelas calçadas. A escala da dimensão vertical é composta por uma série de planos provenientes das fachadas dos elementos presentes no passeio, sejam eles edifícios propriamente ditos ou postes e árvores. A visão humana percebe o espaço dentro de 50 a 55 graus acima da linha do horizonte e dentro de 70 a 80 graus abaixo da linha do horizonte. Assim, ao andar pela rua um pedestre consegue usufruir a dimensão vertical de forma adequada e confortável a partir do nível do térreo e não mais que o segundo andar, ou seja, um limite vertical de 5,45 metros.

A segunda escala se refere à escala da dimensão horizontal que por sua vez, pode ser subdividida em mais três escalas: a escala da unidade, a escala do edifício e a escala da rua. A primeira é o contato mais próximo do pedestre em relação à horizontalidade, pois é o ponto onde os sentidos humanos se manifestam diante dos detalhes arquitetônicos como texturas e acabamentos. $O$ espaço percorrido dentro dessa escala varia de 0 a 7 metros de distância. A segunda escala abrange um conteúdo maior já que o pedestre tem contato com as articulações arquitetônicas entre diferentes edifícios. É o ponto onde o ritmo da caminhada começa a ser moldado dentro de uma distância de até 25 metros.

Por fim, a terceira escala diz respeito à complexidade de um quarteirão dentro de 100 metros percorridos a pé. Geralmente essa é a medida tida como a distância limite na qual o olho consegue enxergar pessoas e objetos em movimento. (CIDADE DE NOVA IORQUE, 2013). É importante notar que para que essas escalas influenciem e funcionem de maneira agradável no caminhar das calçadas, é necessária uma composição variada na paisagem para evitar a monotonia do passeio. Se um edifício ocupar todo o quarteirão, o ato de passear se tornará maçante e monótono. Dessa maneira, é de extrema importância considerar a fruição do passeio. 
Método desenvolvido pelo Departamento de Planejamento de Nova lorque é composto por dois processos: o primeiro envolve a elaboração de desenhos de uma quadra, como plantas, cortes, elevações e perspectivas, e o segundo a avaliação quantitativa e qualitativa daquele ambiente urbano. Para tanto, são utilizadas como base fichas que apresentam tabelas e campos com linhasguia para a elaboração de desenhos e de mapas, presentes na publicação Active Design: Shaping the sidewalk experience: tools and resources (2013).

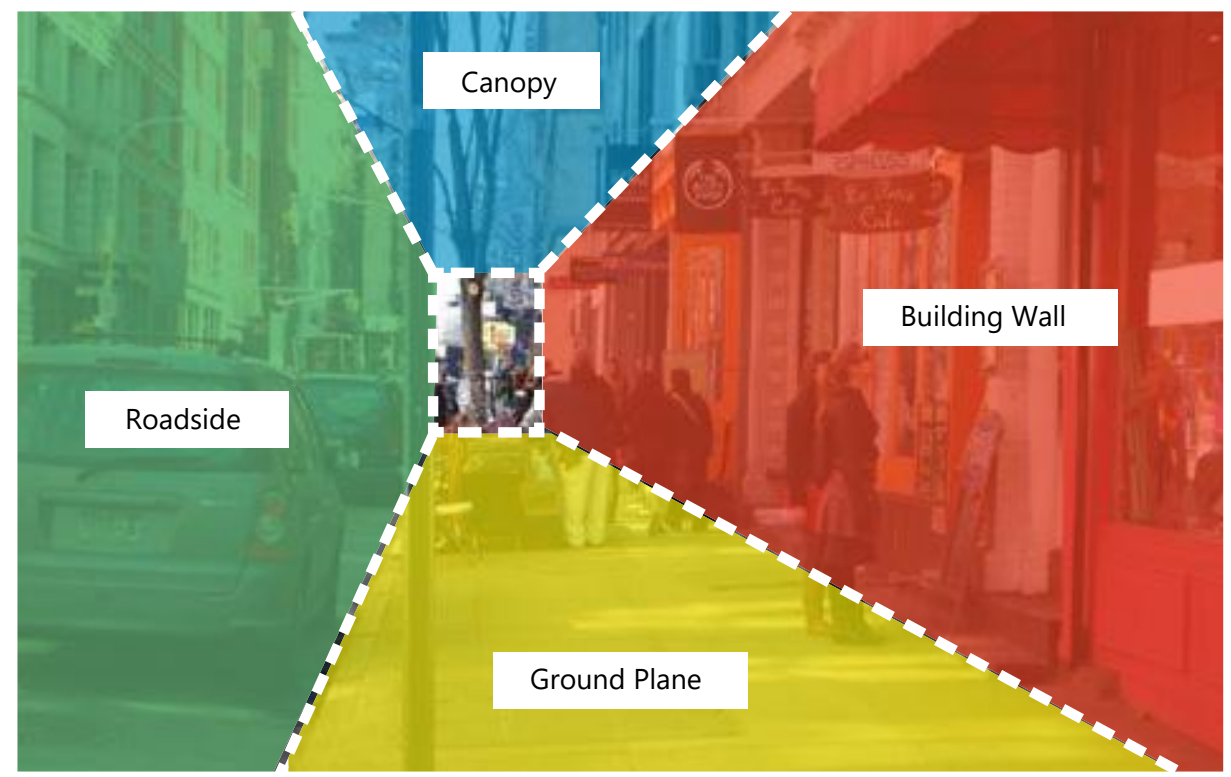

Parte-se do pressuposto que o pedestre é um participante ativo que anda pelo centro de um espaço - espaço que é chamado de "sala da calçada". É um espaço definido por quatro planos: o plano do chão, da cobertura, da estrada e do edifício, de modo que todos contribuem para a qualidade do ambiente e para a experiência global do indivíduo dentro dele.

Esse estudo não avalia as calçadas a partir da perspectiva de quem governa ou de quem as constrói, mas sim de quem as utiliza (CIDADE DE NOVA IORQUE, 2013). Este olhar procura traduzir em espaços mais agradáveis às expectativas dos pedestres.

O documento parte do pressuposto que as calçadas são uma plataforma pública para as pessoas experimentarem um lugar com "nada além de seus próprios pés". Quando são boas, são interligadas, interessantes e convidativas, motivam as pessoas a andar sobre elas e consequentemente a serem fisicamente ativas e saudáveis, sem notarem.

Outro importante aspecto é que se salienta que as calçadas são afetadas por um conjunto de influências físicas, ambientais, culturais e políticas, e, portanto, projetá-las de forma atrativa não é tão simples assim.

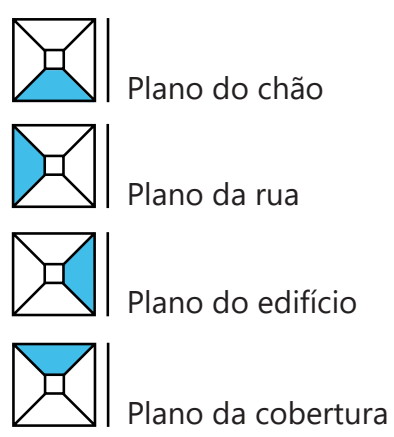

Figura 7: Julgando pela perspectiva do pedestre, a calçada é formada por quatro planos: o do chão, o da estrada o da parede e o da cobertura. Fonte: CIDADE DE NOVA IORQUE, 2013. 
Figura 8: Os pedestres experimentam a calçada com seus sete sentidos. Fonte: CIDADE DE NOVA IORQUE, 2013.

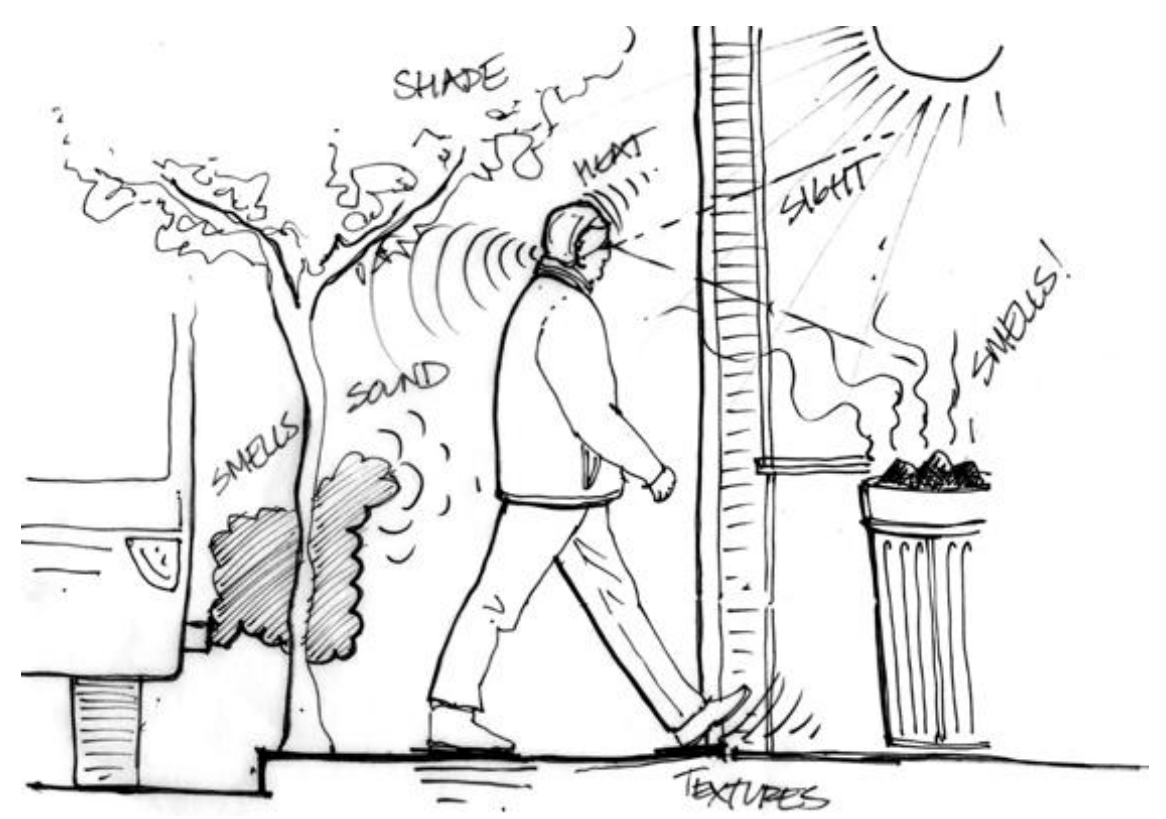

A calçada é frequentemente representada em plano ou seção, em desenhos bidimensionais estáticos que capturam e gravam as principais configurações ou medições. Apesar de essas ferramentas serem úteis para documentar e representar os espaços na calçada, este método desenvolvido pelo Active Design incentiva uma abordagem espacial mais dinâmica, com o objetivo de promover um projeto ativo que usa a calçada como um espaço que incentiva a atividade física diária.

Colocar os pedestres no centro da "sala da calçada " encoraja a consideração de sua perspectiva. Isso significa considerar o espaço físico mantendo "o tempo, o movimento e os sentidos humanos" (CIDADE DE NOVA IORQUE, 2013). Pedestres normalmente experimentam uma calçada movendo-se ao longo dela, durante um período de tempo e a percebem com todos os sete sentidos, incluindo proprioceptivo (posição do corpo e força) e vestibular (que se desloca através do espaço contra a gravidade).

A visão é o sentido humano mais desenvolvido e fundamentalmente importante, mas não deve ser o único levado em consideração. "Os sons do tráfego e as pessoas agitadas podem transformar uma experiência diferente da de pássaros cantando em um passeio tranquilo por uma rua residencial. Latas de lixo transbordando e fumaça de veículos não são tão agradáveis como o aroma de produtos frescos flutuando das janelas da padaria local ou as flores da primavera desabrochando de canteiros na calçada" (CIDADE DE NOVA IORQUE, 2013). A textura do chão sob os pés do pedestre e o alívio da sombra debaixo de uma árvore de dossel verde exuberante em um dia quente de verão também impactam a experiência da "sala da calçada". Visão, cheiros, calor, sombra, som, texturas: todos contribuem para a percepção do pedestre. 


\section{"Sala da calçada"}

A "sala da calçada" é dividida em quatro planos, cada um dos quais nos ajuda a lidar com a complexa interação de participantes, políticas e elementos físicos que moldam a experiência de pedestres na calçada: plano do chão, plano da estrada, plano do edifício e plano da cobertura Apesar da divisão dos planos ser útil para se aprofundar nos detalhes de cada um desses elementos, também há muitas sobreposições. O pedestre nunca experimenta um único plano isolado: cada um desempenha um papel fundamental na composição geral da "sala da calçada". Para o propósito desta investigação, no entanto, os detalhes e os papéis de cada plano foram analisados individualmente.

As próximas páginas irão desmembrar os quatro planos da ilustração abaixo, evidenciando os principais elementos físicos de cada um.

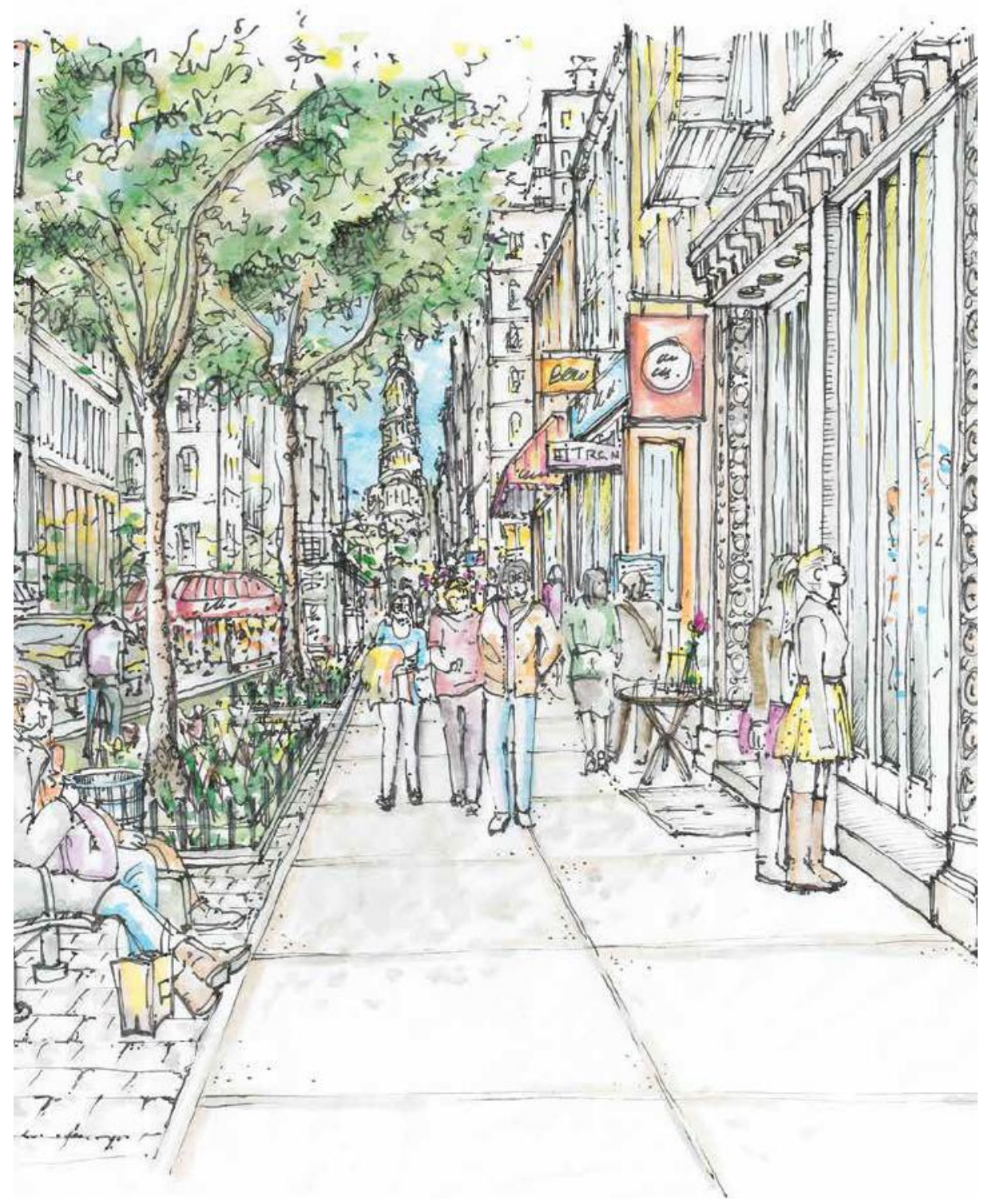

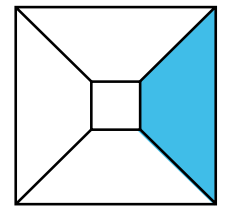
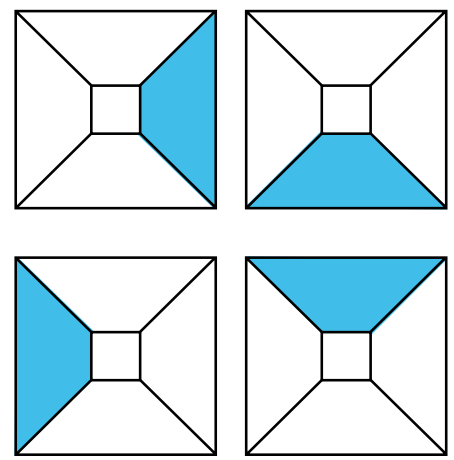

Figura 9: Planos da rua. Fonte: CIDADE DE NOVA IORQUE, 2013.
Figura 10: Ilustração a ser estudada. Fonte: CIDADE DE NOVA IORQUE, 2013. 


\section{Plano 1: 0 plano do chão}

Este plano é o mais comumente considerado na calçada. Sem ele, a calçada não existiria. Um passeio livre com inclinação adequada deve fazer a calçada acessível para vários usuários. Os materiais utilizados e sua facilidade de manutenção impactam drasticamente na estética da calçada, também afetando a sua segurança e navegabilidade. A natureza da região mais próxima do plano do edifício ou da divisa da propriedade privada depende da presença de entradas, cafés, sinalizações, "transbordamento" de lojas, quintal da frente e canteiros. Esta porção do plano do chão pode proporcionar uma vantagem interessante para o passeio livre, e prevê uma boa quantidade de tráfego de pedestres, com pessoas entrando e saindo de edifícios e fazendo uma pausa para olhar em janelas e vitrines. O lado da estrada do plano de chão muitas vezes contém plantio e mobiliário urbano, como lixeiras, bancos, bancas, bases de postes de iluminação e de sinalização, canteiros e troncos de árvores. Quando as árvores são colocadas em canteiros ao lado da calçada, por exemplo, eles devem ser idealmente amplos para garantir a sobrevivência das plantas.

\section{ELEMENTOS FíSICOS DO PLANO DO CHÃO}

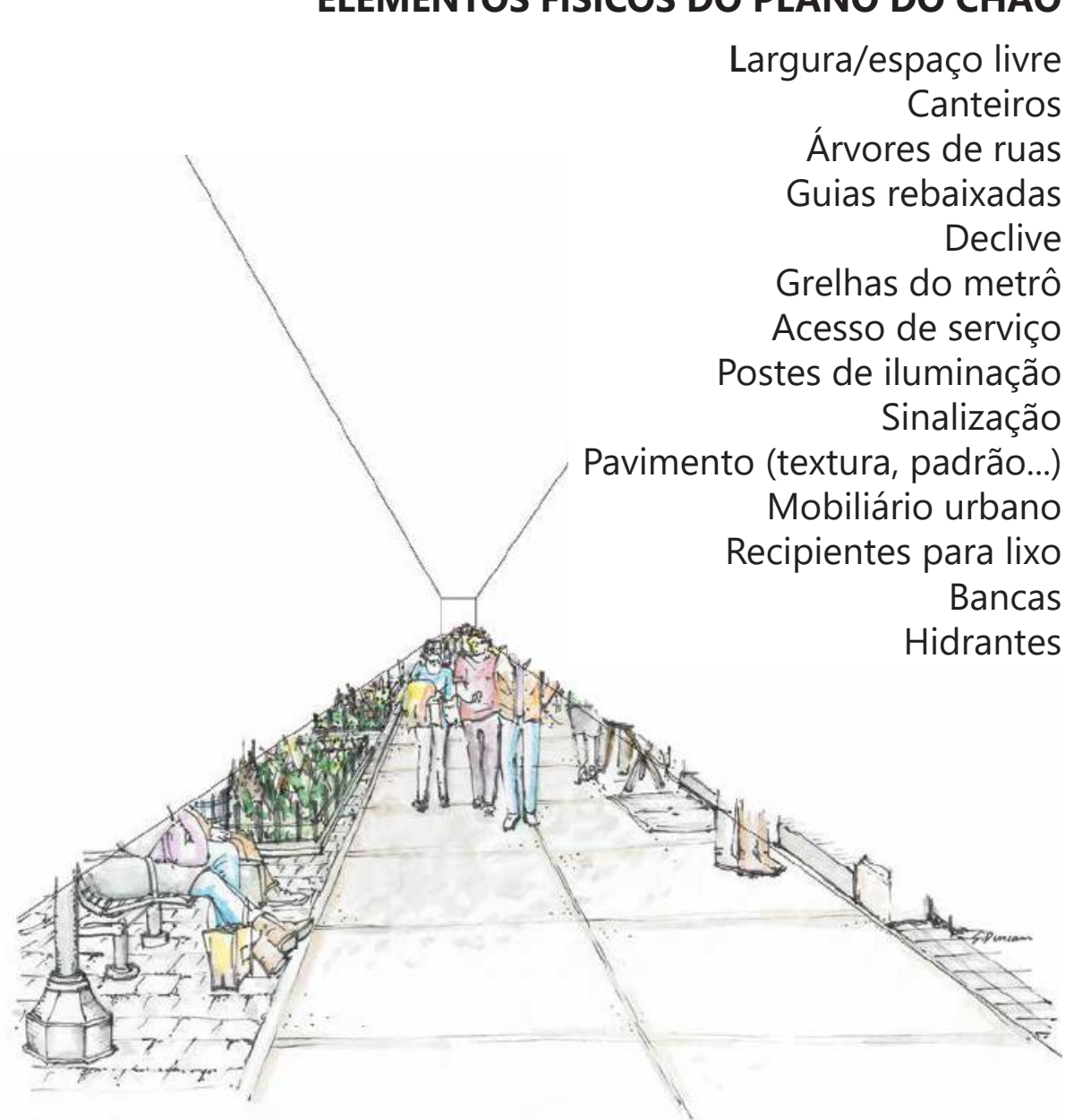




\section{Plano 2: 0 plano da rua}

O plano da rua pode ter grande profundidade, adicionando um número de camadas para a experiência do pedestre. Este plano é definido principalmente pelo ritmo de elementos físicos verticais como troncos de árvores e postes de luz que alinham a borda imediata da calçada. Quanto mais perto um do outro, mais proeminente e densa a primeira camada fica. A segunda camada nesse plano é moldada pela adjacência da estrada imediata e varia muito, dependendo se é uma ciclovia, uma pista de estacionamento ou uma faixa de rodagem em movimento. Carros estacionados e outros objetos estáticos podem atuar como elementos de amortecimento entre veículos em movimento e o pedestre, e podem, em alguns casos, ajudar a aumentar a intimidade da experiência da calçada. Finalmente, o plano do edifício e as árvores do outro lado da estrada adicionam uma terceira camada de profundidade. Enquanto esta camada muitas vezes serve como fundo da experiência da calçada, a ausência de elementos verticais no primeiro plano pode amplificar o efeito do que está acontecendo do outro lado da rua. O volume global e a velocidade de tráfego também impactam a forma como este plano é experimentado.

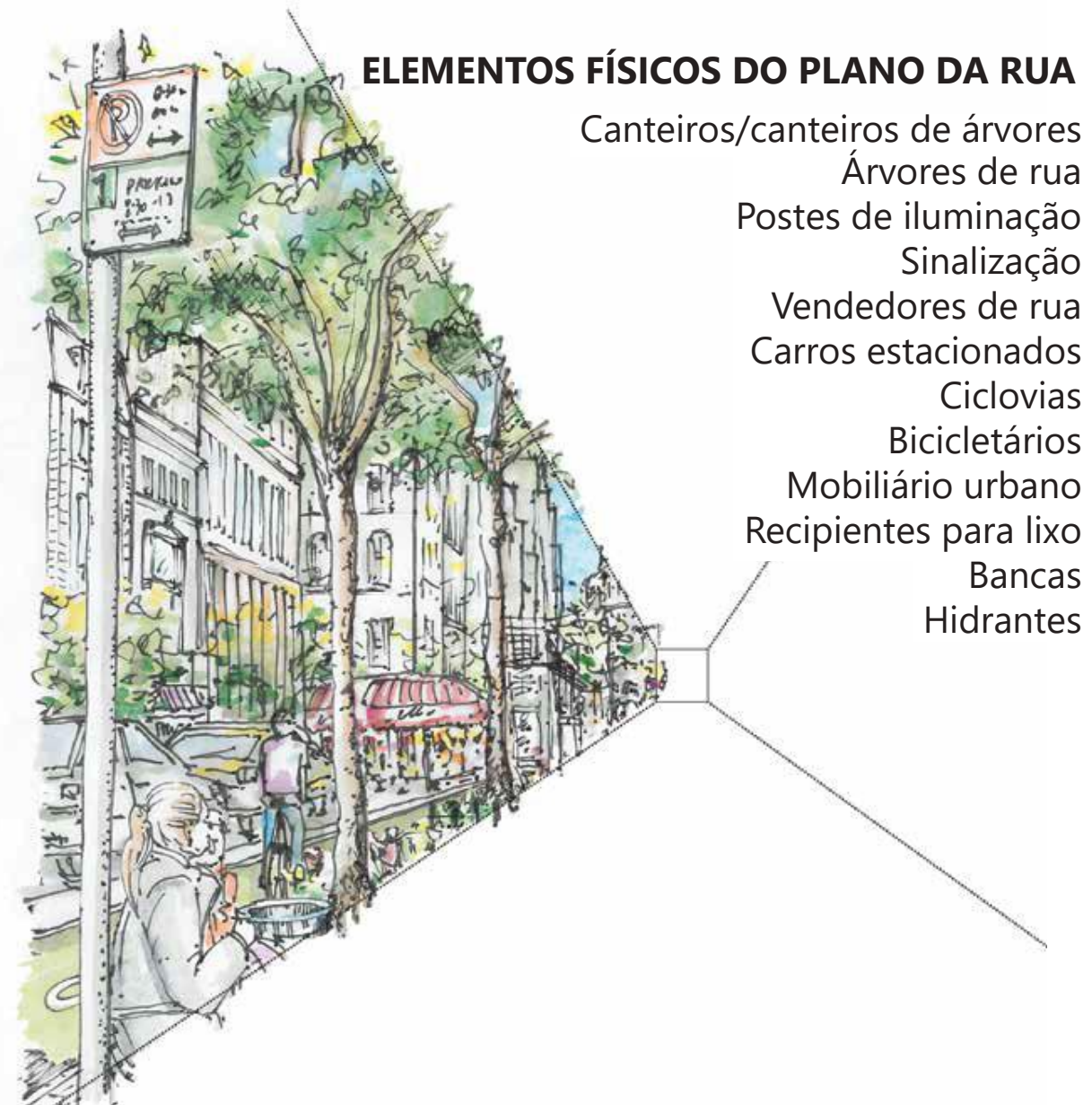

Figura 12: Croqui de um plano da rua. Fonte: CIDADE DE NOVA IORQUE, 2013. 


\section{Plano 3: 0 plano da cobertura}

O plano da cobertura ou do céu é a área que pedestres percebem acima de suas cabeças. Os regulamentos de zoneamentos desempenham um papel importante na composição desse plano. Na maioria dos casos, ele é definido pela quantidade de céu aparente para os pedestres. Nas áreas de maior densidade, no entanto, a construção de planos de edifícios de ambos os lados da rua cortam o plano da cobertura, junto com toldos, alpendres, varandas, sinalizações, saídas de incêndio e outros elementos que se projetam. Calçadas ladeadas de árvores fornecem uma forte e diversificada cobertura cheia de galhos ou vegetação densa, que mudam sazonalmente. $\mathrm{O}$ número de elementos que se projetam para este plano influencia na sensação de enclausuramento na calçada, bem como na quantidade de sombra e abrigo para pedestres em condições climáticas extremas. Marcos distantes são muitas vezes aparente no plano da cobertura.

Figura 13: Croqui de um plano da cobertura.. Fonte: CIDADE DE NOVA IORQUE, 2013, P. 56.

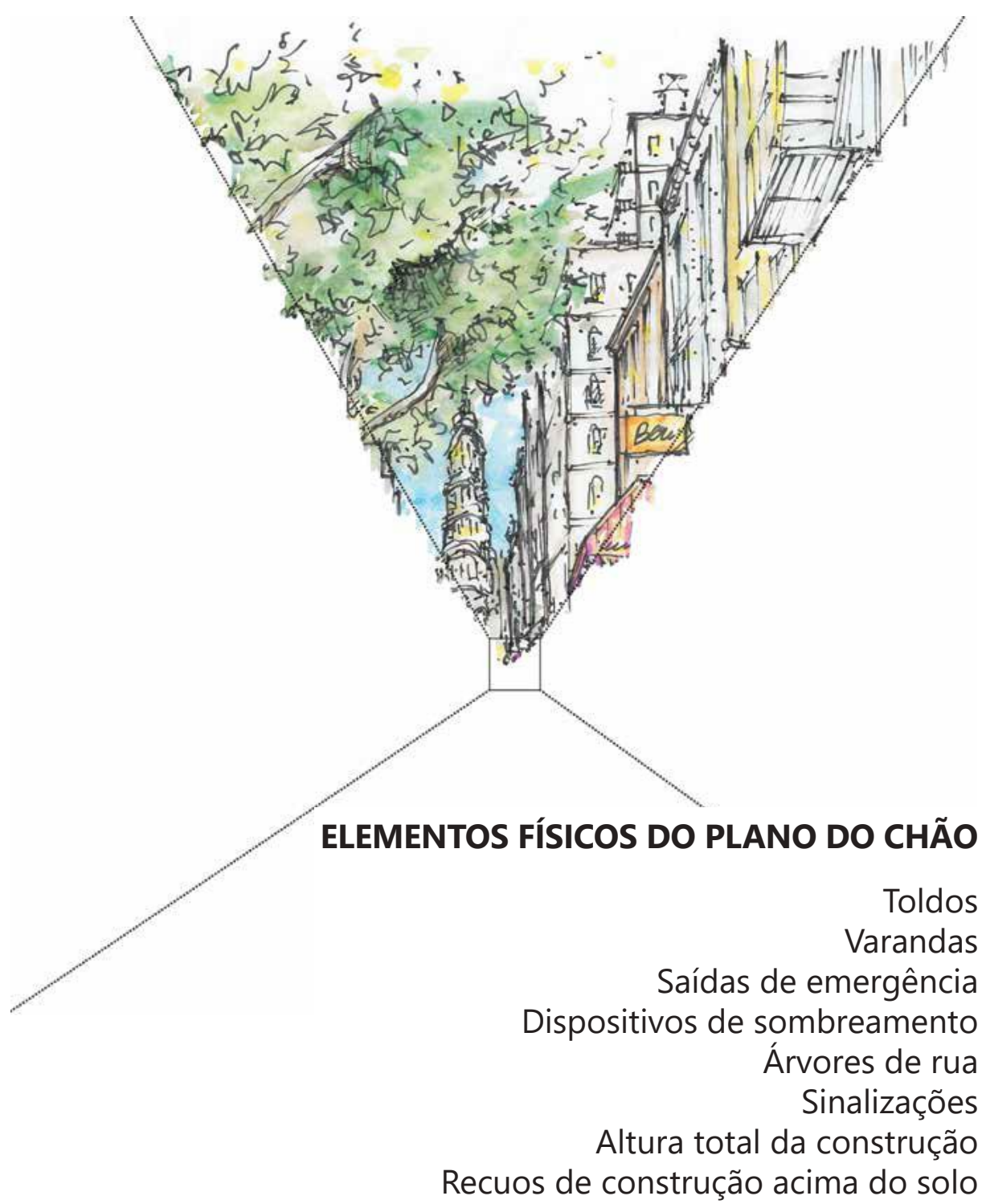




\section{Plano 4: 0 plano do edifício}

O plano do edifício começa no ponto em que a calçada se encontra com a linha da propriedade privada. Zoneamentos normalmente têm grande impacto sobre este plano. A posição do plano do edifício - se um edifício é recuado ou não - pode afetar significativamente a experiência na calçada. Para edifícios que ficam na divisa da propriedade, os ritmos verticais, a profundidade e as texturas das fachadas ajudam a criar interesse e quebrar a massa do edifício para a escala dos pedestres. Várias entradas próximas, com pessoas que entram e saem dos edifícios em intervalos regulares, podem ajudar a garantir que uma calçada esteja ativa e segura. O nível de transparência do plano do edifício ajuda a definir o grau em que os usos dentro do piso térreo estão evidentes. Sinalização e toldos afetam a parte superior deste plano, enquanto usos ativos como cafés ajudam a definir sua porção inferior. Para edifícios recuados da divisa, o plano do edifício ainda tem certo impacto, mas o que ocorre neste recuo também contribui para a experiência dos pedestres. Áreas com recuos menores muitas vezes apresentam plantações, cafés, sinalizações, latas de lixo e mobiliário urbano; zonas caracterizadas por recuos maiores, com guias rebaixadas, tendem a conter carros estacionados, árvores maiores e móveis de jardim.

\section{ELEMENTOS FíSICOS DO PLANO DO EDIFÍCIO}

Uso do solo

Recuo no térreo

Altura total de construção

Recuos de construção acima do solo Jardim da frente

Estacionamento na rua

Comprimento de propriedades

Fachadas

Entradas

Transparência

Portões de segurança

Articulação arquitetônica

Sinalizações

Toldos

Varandas

Saídas de emergência

Dispositivos de sombreamento

Usos ao ar livre

lluminação 
Figura 15: Planta de piso proposta pelo método norteamericano. Fonte: CIDADE DE NOVA IORQUE, 2013

Figura 16: Elevação das fachadas. Fonte: CIDADE DE NOVA IORQUE, 2013

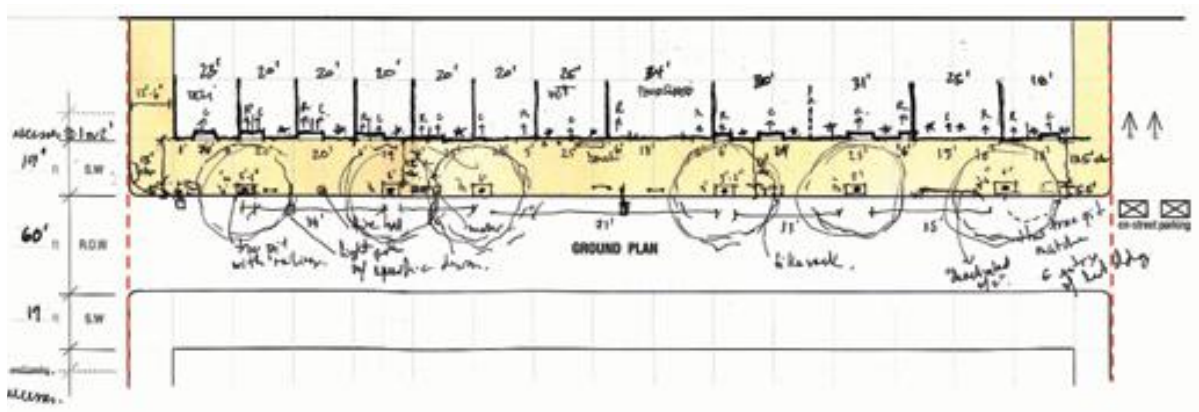

Os levantamentos em campo iniciam-se pela elaboração de duas plantas, uma de piso e outra de um plano que seria equivalente a uma cobertura. Na planta de piso, são localizados, por meio de uma legenda específica, todos os obstáculos presentes no passeio, como postes, entradas para veículos, caixas de inspeção e troncos de árvores, como pode ser visto na Figura 15. Já na planta de "cobertura", são localizados elementos como copas de árvores e coberturas de pontos de ônibus, que influenciam a relação com o pedestre com o espaço e o conforto dos usuários. Como base para essas plantas, foi utilizado o desenho de uma quadra genérica, de 100 metros de comprimento.
Figura 17 (Esquerda): Corte da calçada. Fonte: CIDADE DE

NOVA IORQUE, 2013.

Figura 18 (Direita): Corte da via. Fonte: CIDADE DE NOVA IORQUE, 2013.

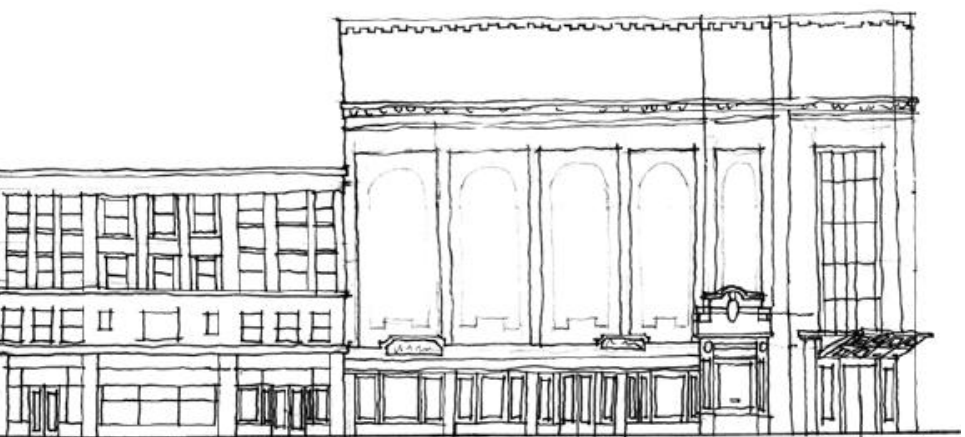

As elevações (Figura 16) permitem apreender aspectos como o gabarito das edificações e a relação entre cheios e vazios nas fachadas, além de questões relacionadas à sua atratividade - as fachadas ativas, como as de lojas e alguns serviços e restaurantes, são mais permeáveis visualmente e configuram um ambiente urbano mais atrativo para os pedestres do que o estabelecido, por exemplo, quando há um muro separando a calçada dos lotes.
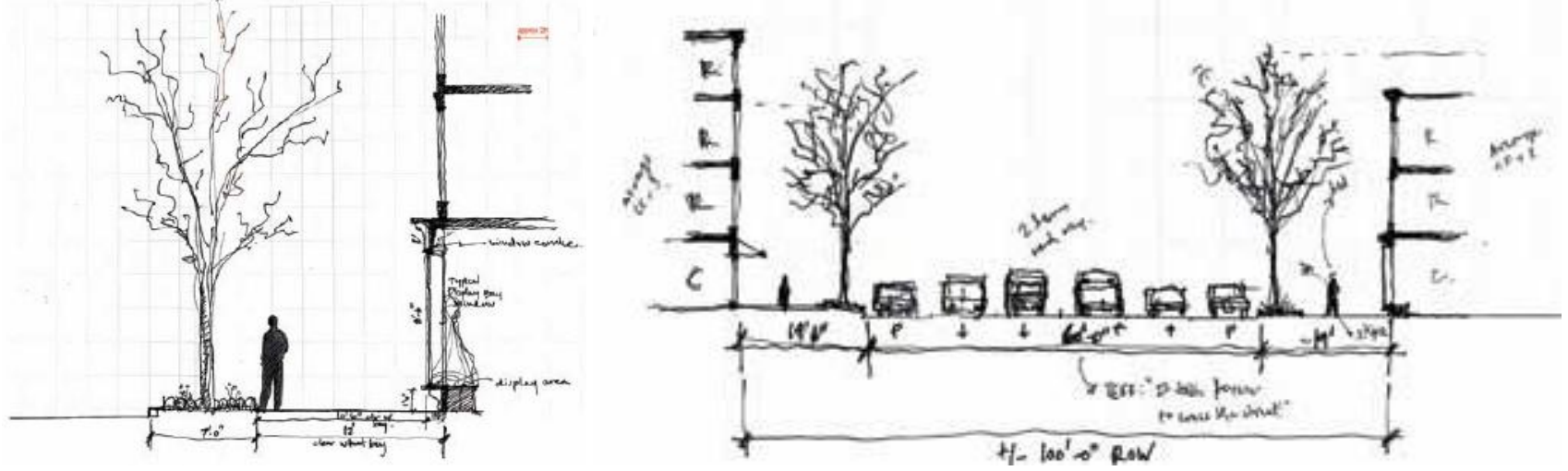
Os cortes explicitam a relação entre a altura das edificações e a largura da via, além da relação dessas dimensões com a escala humana, como pode ser visto nas Figuras 17 e 18.

Por fim, as perspectivas da calçada são elaboradas dividindo-se o espaço em quatro planos: o piso, a "cobertura", as fachadas e o plano da via. Para cada um desses planos, é realizado um desenho isoladamente, sobre uma base com linhas guia (Figura 19). Quando esses desenhos são unidos (Figura 20), pode-se perceber melhor a relação entre os elementos que compõem o espaço do passeio e a maneira como o pedestre os percebe.
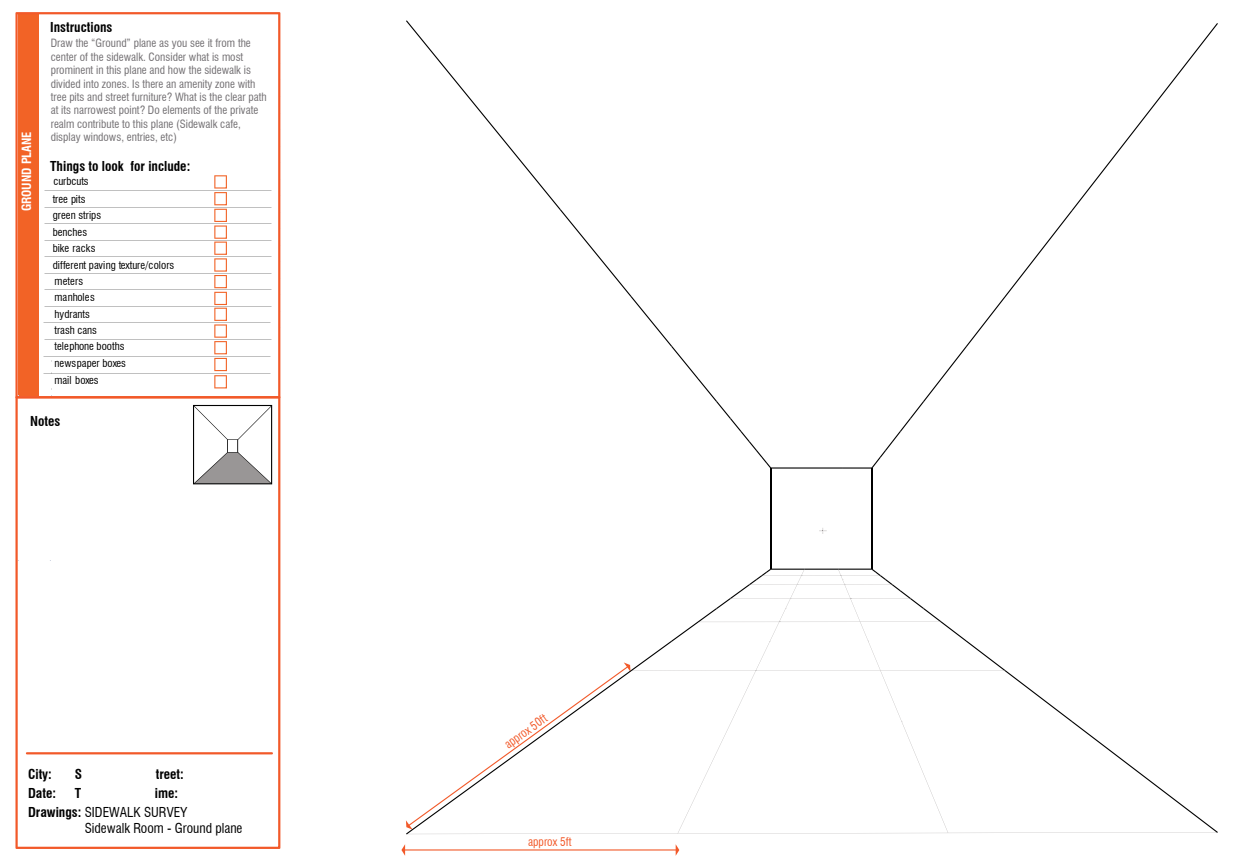

Figura 19 (Superior):

Base para a elaboração da perspectiva do piso. Fonte: CIDADE DE NOVA IORQUE, 2013.

Figura 20 (Inferior esquerda): Perspectiva da calçada. Fonte: CIDADE DE NOVA IORQUE, 2013.

Figura 21 (Inferior direita):

Croqui de uma calçada. Fonte: CIDADE DE NOVA IORQUE, 2013.
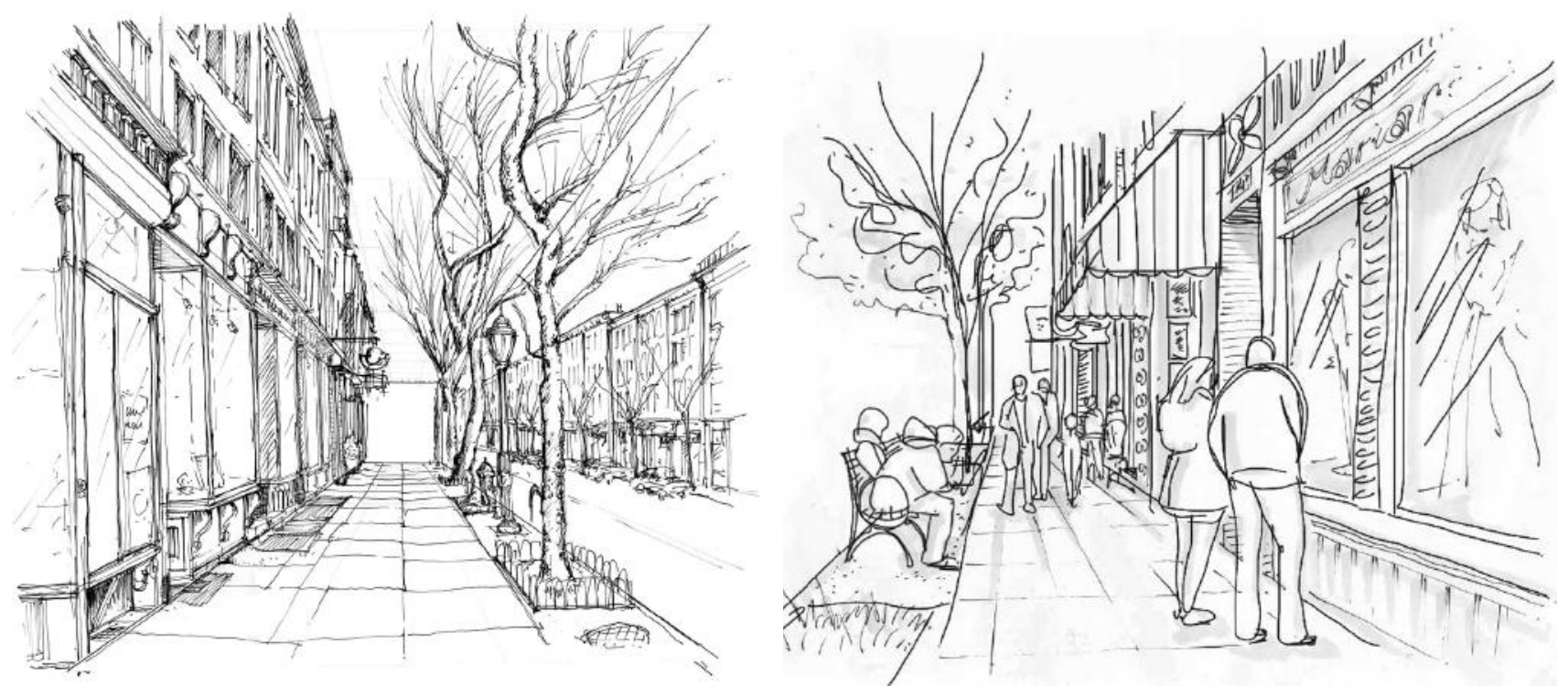
A segunda parte do método consiste em avaliações quantitativas e qualitativas, para as quais também existem fichas específicas. Essas avaliações dizem respeito ao traçado urbano do local, às características físicas da via e aos usuários. Assim, são analisadas questões como o uso do solo, os fluxos de pedestres e veículos, o perfil dos usuários que passam pelo local, a conectividade da via, as características das edificações que delimitam a rua e o desempenho ambiental daquele espaço. Paralelamente, são realizadas algumas avaliações qualitativas de aspectos como segurança, conectividade, acessibilidade, escala do pedestre, diversidade e sustentabilidade.

Segundo o Active Design existem alguns fatores que contribuem para a experiência da calçada ativa:

\section{Acessibilidade}

Projetar uma calçada para acomodar adequadamente a maior gama de usuários evolumes de pedestres é crucial para seu sucesso. Devese incentivar a criação de um ambiente mais amigável, que possa ajudar a melhorar a qualidade de vida de todos, especialmente das crianças, idosos e pessoas com deficiência. Independentemente da escala do passeio, pode-se projetar um ambiente multissensorial que melhora a experiência e aumenta a usabilidade da calçada. Um ambiente inclusivo aborda não apenas as necessidades do usuário, mas também suas preferências. Sendo assim, as calçadas devem acomodar os usuários de todas as idades, desde crianças a idosos, e com uma vasta gama de habilidades físicas e mentais. Alguns indivíduos que têm dificuldades para andar podem ser mais ativos se souberem que terão muitos lugares para sentar e descansar ao longo do caminho. As crianças experimentam calçadas a partir de um ponto de vista diferente dos adultos, uma consideração particularmente importante nas rotas usadas com frequência para caminhar até a escola. Limitar os obstáculos e melhorar os sinais multissensoriais dentro do ambiente tridimensional da calçada reduz dificuldades para aqueles que são cegos ou têm visão diminuída. Um convidativo e inclusivo design faz com que cada usuário se sinta confortável.

\section{Conectividade}

Segundo o Active Design, se uma calçada não está ligada em ambas as extremidades de algum modo, é pouco provável que seja bem utilizada. Idealmente, a conectividade deve ser a consideração inicial dos esforços de planejamento de bairro. Uma calçada bem conectada tem inúmeros cruzamentos e curtos padrões de blocos, e não tem becos sem saída. Uma boa rede de calçadas permite às pessoas escolher vários caminhos, incluindo a rota mais direta entre 
sua origem e destino, permitindo que a caminhada seja um modo eficiente de transporte. Redes de calçada menos conectadas são frequentemente encontradas em desenvolvimentos suburbanos. Ruas sem saída, "cul-de-sacs" e padrões de rua complicados podem forçar os pedestres a andar maiores distâncias para chegar a destinos que poderiam estar relativamente perto, muitas vezes resultando em uma preferência para o uso de veículos para viagens locais.

\section{Segurança}

A experiência da calçada só é agradável, segundo o Active Design, se os usuários se sentem seguros. Calçadas devem ser devidamente iluminadas à noite, com iluminação na escala do pedestre, uniformemente espaçada e adequada para fornecer o nível correto de iluminação. Quando o plano do chão é bem iluminado, pode eliminar os riscos de tropeços. Estar de frente para as entradas do edifício e para as janelas pode ajudar os caminhantes a sentirem que outras pessoas estão por perto, pode fazer a calçada mais interessante e fazer com que as distâncias pareçam mais curtas. Adicionar às unidades residenciais um uso misto de áreas comerciais aumenta a probabilidade de que uma área seja preenchida após o horário normal de expediente. Restaurantes e estabelecimentos que suportam populações residenciais podem ajudar as calçadas permanecerem ativas durante o dia e à noite, mantendo "os olhos na rua".

\section{Escala Humana e complexidade}

Entender como o corpo percebe o espaço é um primeiro passo na concepção de calçadas que melhoram o conforto humano, de acordo com o Active Design. Isso requer decisões conscientes que melhoram suas características multissensoriais e o reconhecimento que calçadas são ambientes tridimensionais e não apenas planos estáticos. As escalas, essenciais para um melhor ambiente, são baseadas em envoltórios espaciais definidos pelas fronteiras variáveis ao longo do percurso de deslocamento. Estes envoltórios criam complexos recintos e fazem com que cada calçada seja única, dependendo de sua composição. Uma das características que definem o envoltório espacial é a construção do plano do edifício; este documento discute a complexidade desse plano usando duas dimensões lineares: a altura vertical do plano do edifício que passa imediatamente ao lado de pedestres enquanto estão andando - e a distância horizontal - distância na rua que é visível para o pedestre.

a. Quebrando a dimensão vertical:

Calçadas podem ser limitadas por edifícios altos, pequenos 
Figura 22: A altura entre o chão e a divisão entre os dois primeiros pavimentos do edifício é a mais importante na escala do pedestre. Fonte: CIDADE DE NOVA IORQUE, 2013, P. 33 ou por nenhum edifício. A experiência dos pedestres é fortemente influenciada pela altura vertical do plano do edifício. O olho humano percebe tipicamente o espaço dentro dos ângulos de 50$55^{\circ}$ acima e $70-80^{\circ}$ abaixo de uma linha horizontal. Se assumirmos a altura média dos olhos de alguém andando na rua, percebese que a altura vertical mais intensamente vivida pelo pedestre é a linha entre os dois primeiros pisos de um edifício. Esta parte inferior do plano do edifício é bem sucedida quando contém um nível suficiente de detalhes e articulações, onde é mais legível para o olho humano e torna a experiência calçada interessante e envolvente para o pedestre.

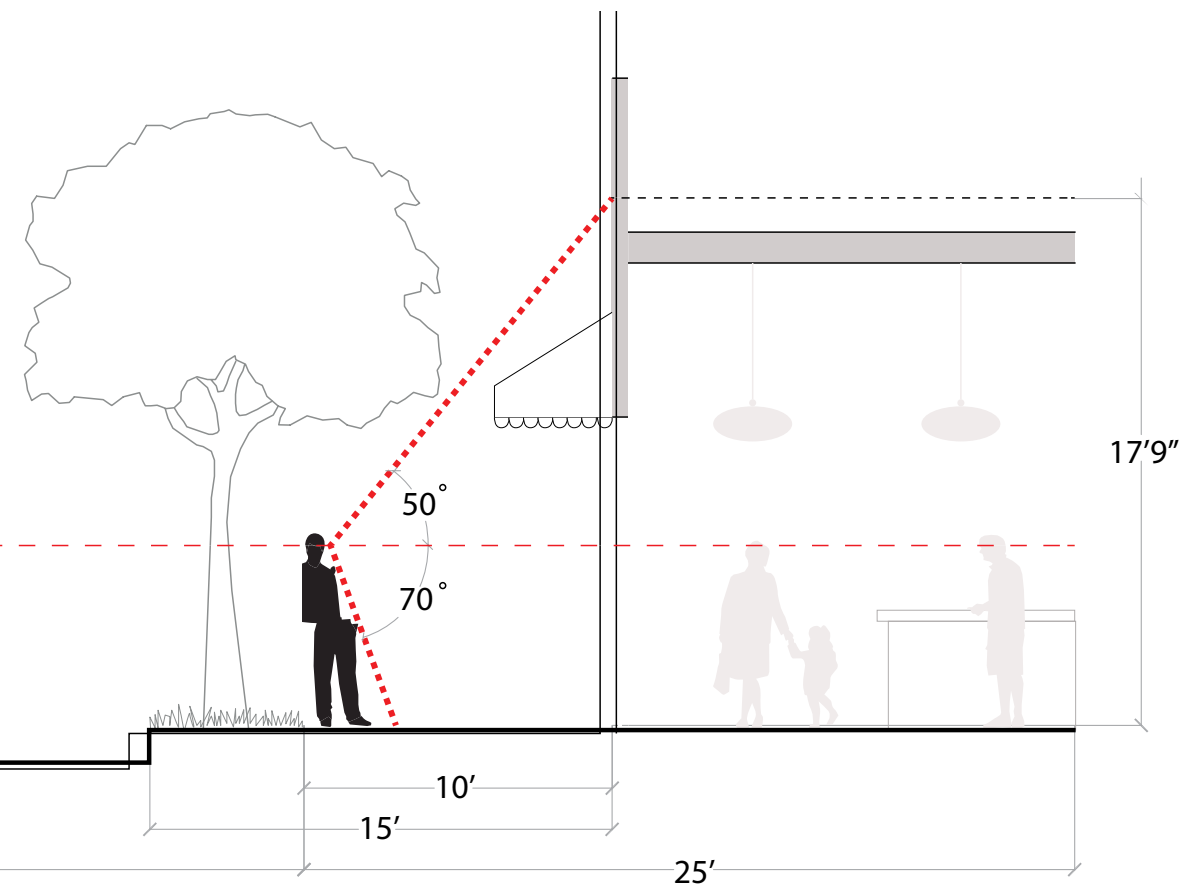
São elas:

I. A Escala da Rua/Quadra: 100 metros é muitas vezes considerada a maior distância que o olho humano pode ver as pessoas ou objetos em movimento. Nessa escala, as pessoas veem pontos de referência, corredores de edificações ou pontos desaparecendo. Este estudo utiliza esta distância como o comprimento total da "sala da calçada" e sugere usá-lo como um comprimento de calçada apropriado para estudar como amostra.

II. A Escala do Edifício: 25 metros é a distância em que o olho humano pode começar a ler expressões faciais. É a meia-escala de ritmo muitas vezes demonstrada quando há uma série de edifícios diferentes e, portanto, distinções verticais entre eles, na mesma quadra. Quando um único edifício se estende a todo o comprimento de um quarteirão, ele pode rapidamente tornarse monótono e repetitivo para a pessoa andando ao lado dele. 
Nestes casos, a variedade é encorajada através da utilização de diferentes materiais, padrões de janela, linhas de cornija, e outras articulações arquitetônicas.

III. A Escala do Estabelecimento/Unidade: A menor escala de experiência do pedestre ocorre dentro dos 0-7 metros mais próximos do espectador. Esta é a escala em que os sentidos são mais engajados com as complexidades da articulação da fachada, entradas ativas, transparência, texturas, toldos, sinalização e detalhes arquitetônicos.

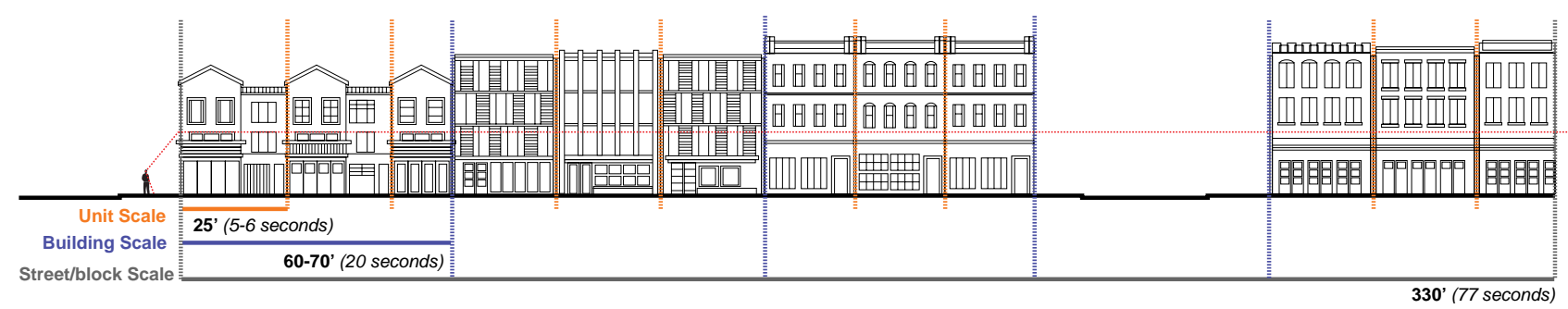

Variedade contínua

a. Variedade de velocidade:

As funções de ruas e calçadas são percebidas em várias velocidades. Na última metade do século, ruas e calçadas muitas vezes foram concebidas com a velocidade do automóvel em mente. No entanto, é importante se concentrar no ritmo de passeio humano, com média de 4 a $5 \mathrm{~km} / \mathrm{h}$, na concepção destes espaços. Nessa velocidade mais lenta, os pedestres têm mais tempo do que os passageiros do automóvel para absorver seus arredores. É importante projetar com complexidade suficiente de detalhes para manter o interesse do pedestre. Mesmo dentro da velocidade média de caminhada de 4 a $5 \mathrm{~km} / \mathrm{h}$, é importante ter em mente a variedade de velocidades em que as pessoas se movem. Áreas de alta densidade requerem calçadas que permitam as pessoas se moverem para onde elas queiram ir rapidamente, mas as melhores calçadas também devem permitir várias velocidades de movimento. Um caminho livre adequado para passagem permite caminhar em um ritmo acelerado, mas a criação de um ambiente que convida as pessoas a vaguear e pausar, ou que oferece a oportunidade de parar por períodos de descanso ou refresco, pode adicionar diversidade e interesse na "sala da calçada".

b. Variedade de atividades:

Ao permitir diversas velocidades de movimento, os melhores passeios possibilitam uma variedade de atividades. Em um nível básico, calçadas permitem que os pedestres caminhem sem ter que usar o leito da estrada e sem ter que enfrentar perigosos conflitos com veículos. As melhores calçadas servem como palcos 
para inúmeras outras atividades, incluindo passeios sem pressa (para ver e ser visto), encontros casuais entre velhos conhecidos, interação diária com personagens locais e apresentações surpresa para estranhos. O espaço da calçada deve permitir que os pedestres possam dar um passo de lado e conversar com seus vizinhos, fazer uma pausa na fachada de um edifício para vasculhar um saco e descansar debaixo da sombra de uma árvore e dar um telefonema. Quando apropriado, devem permitir o descanso, que os cafés e restaurantes se estendam para fora e ativem a rua e que as lojas suavizem as fronteiras entre o espaço público e o privado. Elas devem fornecer uma variedade de funções para diversos usuários em momentos diferentes, agindo como o quadro fundamental para o domínio público. 


\section{Quadro resumo}

- A dimensão humana foi deixada em um segundo plano por décadas no projeto e no planejamento das cidades, em detrimento a questões que ganharam (e ainda ganham) importância e força, como por exemplo, a adaptação das cidades ao aumento do tráfego de automóveis.

- O espaço reduzido, o ruído, a poluição, o risco de acidentes, os obstáculos, os assaltos, entre outros, são fatores comuns na maioria das grandes cidades da atualidade, fazem com que os pedestres não consigam efetuar uma atividade primordial, que não os diferem por gênero, faixa etária ou etnia: exercer ato de caminhar.

- Juntamente com o desafio de mudar a morfologia urbana para densidades mais altas em cima de uma estrutura urbana existente, o tema da reutilização de edifícios na cidade de São Paulo tornou-se uma questão urgente em todo o centro da cidade.

- Ao relacionar a Ergonomia com morfologia urbana física, pode-se analisar o espaço diante de uma visão que envolve não só a identificação do gabarito urbano, mas também a identificação de obstáculos fixos, obstáculos móveis e de questões de conforto ambiental e segurança humana.

- A "caminhabilidade" é resultado de uma qualidade urbana e é algo físico, que contribui para a cidadania, através dos encontros urbanos.

- A "andabilidade" "quando o ambiente construído apoia e encoraja o caminhar e promove conforto e segurança ao pedestre, conectando pessoas em diferentes destinos dentro de um tempo e esforço razoável, e oferece interesse visual no percurso através da rede".

- Southworth e Pozueta definem e propõem atributos indispensáveis para obter uma cidade com atrativos para o pedestre.
- Nométododesenvolvido pelodepartamento de Planejamento de Nova lorque - Active Design, parte-se do pressuposto que o pedestre é um participante ativo que anda pelo centro de um espaço - espaço que é chamado de "sala da calçada".

- O Active Design salienta que as calçadas são afetadas por um conjunto de influências físicas, ambientais, culturais e políticas, e, portanto, projetá-las de forma atrativa é de grande complexidade.

- As principais características, segundo Active Design de uma calçada com qualidades positivas são:

Sustentabilidade e Resiliência: Considerar o contexto local quanto ao clima, plantações e árvores, materiais, qualidade do ar e gestão de águas pluviais.

Segurança: Certificar-se que as calçadas são projetadas com iluminação, gradientes e materiais adequados, para permitir a utilização segura $24 \mathrm{~h}$ por dia.

Escala Humana + Complexidade: Usar o detalhamento arquitetônico, entradas, transparência, paisagismo e assim por diante para aumentar a complexidade nos pisos inferiores, ajudando a complementar a escala humana e quebrar o ritmo do comprimento da calçada.

Variedade contínua: Certificar-se de uma experiência com variedade contínua. Considerar as diferentes velocidades em que as pessoas se movem e a variedade de atividades que podem ocorrer dentro da "sala da calçada".

Conectividade: Certificar-se de que as calçadas fornecem orientação espacial clara e que sejam contínuas, conectando pessoas a destinos e não resultando em becos sem saída.

Acessibilidade: Garantir a acessibilidade dos vários usuários, considerando diferentes idades e habilidades. 

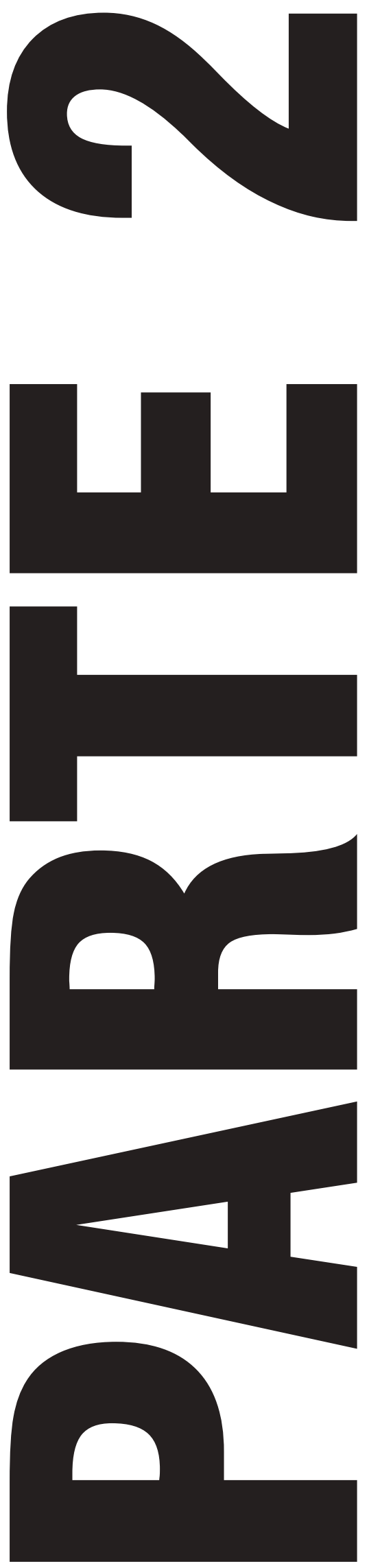


\section{Aplicações do método de avaliação ergonômica no ambiente urbano}

Antes da proposição do método objeto desta tese, decidiu-se aplicar os métodos de referência com o objetivo de aferi-los. Esta aferição mostra-se importante para a construção do método proposto na tese, uma vez que possibilita a identificação de lacunas e ajustes metodológicos. Conforme mostrado no fluxograma da página 05 foram selecionadas quatro pesquisas. O trabalho intitulado: Desenho Urbano, Mobilidade e fluxo de pedestres aborda aspectos relacionados ao adensamento urbano e as formas de aferição dos fluxos de pedestres no ambiente urbano e o consequente dimensionamento das calçadas. Os resultados encontrados foram aplicados nas pesquisas subsequentes. A segunda pesquisa intitulada: Adensamento urbano com qualidade ambiental, mobilidade e acessibilidade na República e Bela Vista abordou o método proposto sob a ótica da avaliação do ambiente urbano com critérios e parâmetros estabelecidos dentro dos métodos de referência apresentados. A terceira pesquisa intitulada: Avaliação ergonômica das funções e atividades da habitação: áreas externas: expectativas e necessidades de conforto e bem-estar, além de retomar os critérios e parâmetros estabelecidos no segundo trabalho trouxe a aplicação do método desenvolvido por outra referência. A última pesquisa intitulada Paraisópolis: avaliação, sob o enfoque ergonômico dos espaços externos trouxe a discussão da aplicação dos métodos de referência em áreas de habitação com caráter social com diversidades não encontradas nos espaços urbanos ditos "convencionais". 
A duas primeiras pesquisas aqui apresentadas têm como pano de fundo o projeto temático: Edificação e desenho urbano com adensamento e qualidade ambiental: habitação de interesse social na recuperação de áreas urbanas degradadas desenvolvido com apoio PNPD/CAPES, realizado junto ao LABAUT. Os resultados aqui apresentados referem-se à aplicação de métodos de referência relacionados à mobilidade e à acessibilidade.

Esta pesquisa buscou investigar arranjos espaciais urbanos que promovessem o adensamento com qualidade ambiental (acesso ao sol, ventilação natural, geração de energia, inserção de áreas verdes, mobilidade e acessibilidade). As pesquisas coordenadas pela autora desta tese envolveram não só a habitabilidade da unidade como também do entorno, com preocupações climáticas, de infraestrutura e de eficiência energética. O conforto ergonômico foi estudado juntamente com os componentes térmica, acústica e luminoso, de forma a propor parâmetros com condições ambientais adequadas que foram aplicados tanto às edificações como aos espaços públicos.

A inclusão do desenho urbano na pauta do planejamento da cidade visa agregar valor ao projetar espaços públicos que são pensados para favorecer os usuários, propiciando a convivência social com conforto ambiental de modo a minimizar possíveis impactos negativos gerados pelo meio físico. Atentando-se para as variáveis ambientais, os problemas mais comumente encontrados são relativos às questões ergonômicas de conforto higrotérmico, qualidade do ar, ventilação, acesso ao sol, entre outras. 


\title{
Aplicação do Método 1:
}

Desenho urbano, mobilidade e fluxo de pedestres

\begin{abstract}
A escolha da área para estudo foi baseada na inserção urbana, no potencial de adensamento e adequação do desenho urbano com condições ambientais favoráveis. Considerandose estes fatores, aliados ao projeto temático (PNPD/CAPES), determinou-se a área localizada no bairro do Cambuci como objeto de estudo. A região em questão é dotada de infraestrutura com localização estratégica no centro da cidade e está próxima de várias linhas de transporte de massa, como o metrô e trem, além de linhas de ônibus que cruzam a área .

A região apresenta além desta centralidade estratégica, a proximidade de áreas em valorização ou que passarão por processo de valorização imobiliária, já que fica no limite da Operação Urbana Centro. Há ainda a previsão de construção da linha 6 - laranja do Metrô, com projeto em estudo que incluirá as estações Aclimação (Lavapés) e Glicério, esta linha ligará Pirituba, na zona oeste, à Cidade Líder, na zona leste.
\end{abstract}

A área está inserida na subprefeitura da Sé e compreende os distritos da Liberdade e Cambuci, sua maior parte, no entanto, está localizada no Cambuci, sendo esta a denominação adotada para este trabalho.

A região central e degradada pode ser incluída também da chamada "baixada do Glicério", que atualmente passa por um processo de especulação imobiliária, em virtude da Operação Urbana Centro realizada pela Prefeitura com participação da iniciativa privada. A Operação prevê a melhorias na região com o uso de instrumentos urbanísticos para incentivar o investimento na região e gerar contrapartida financeira para propiciar as melhorias. Apesar de a área de estudo estar no limite imediato externo da Operação Urbana, não se pode ignorar o impacto que tais mudanças provocarão no seu entorno. Os usos previstos são de caráter misto, com comércio, residências, empresas e hotelaria, para que seja viável a construção de empreendimentos maiores é permitido o remembramento de lotes e os coeficientes de aproveitamento poderão ser elevados mediante concessões onerosas (SEO 2009).

Neste trabalho, o conceito de mobilidade urbana pode ser sintetizado na comodidade do deslocamento individual dentro do 
espaço urbano fazendo uso de um ou mais meios de transporte ou mesmo caminhando. Seu conceito é de difícil definição por se tratar de um tema amplo que pode envolver combinações intermodais de transporte, além das próprias questões urbanísticas da cidade e as condições físicas do cidadão. Tratase de um conceito múltiplo, que envolve não apenas variáveis físicas e quantitativas, mas também questões sociais, econômicas e políticas (VIANNA JÚNIOR 2000).

A acessibilidade por sua vez está inserida no conceito da mobilidade, já que envolvem as condições e modos como podem ser feitos os deslocamentos por cada indivíduo dentro da cidade. Na definição apresentada pela NBR 9050

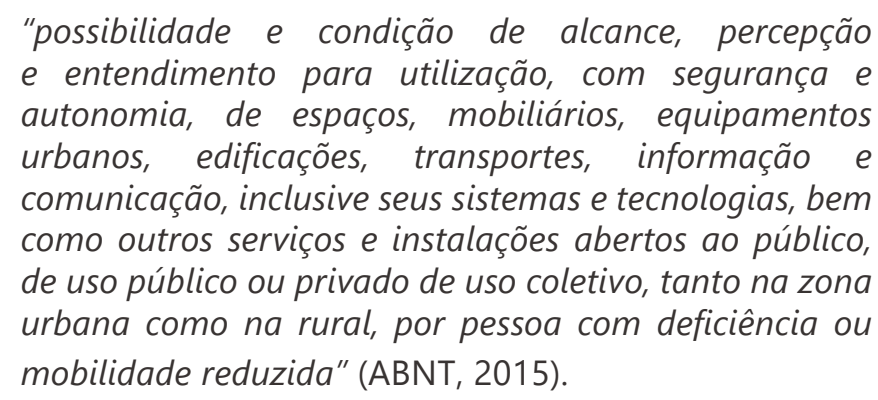

A partir da proposição de adensamento habitacional e intensificação do uso misto do local foram propostos novas dimensões de calçadas e seus passeios para que comportassem com conforto o novo fluxo que será gerado com o crescimento populacional (NAKAMURA e KRONKA MÜLFARTH, 2013). Os cálculos para determinação da largura adequada da faixa livre, a faixa destinada à circulação de pessoas, foram feitos de duas maneiras:

1. A primeira baseada no possível fluxo de pedestres, já que é difícil a previsão exata de quantidade de pessoas por minuto por metro que circularão após o adensamento, utilizando-se a fórmula indicada na NBR 9050.

2. O segundo método envolve a densidade populacional prevista para as unidades habitacionais, em habitantes por hectare.

O cálculo efetuado utilizando-se o fluxo de pedestres foi baseado no fluxo atual de pedestres, estimado através das visitas e com a tese de doutorado de Marcos Vinícius Carvalho que elaborou um esquema indicativo de espaçamento de pedestres e taxa de fluxo segundo o Highway Capacity Manual (2000). O Manual apresenta seis níveis de serviço que variam de acordo com o número de pedestres por minuto por metro, a liberdade de movimento e velocidade vão diminuindo com o aumento do fluxo. 
Figura 24: Níveis de Serviço elaborado pelo autor segundo o HCM (2000). Fonte: CARVALHO, 2006, P. 34.

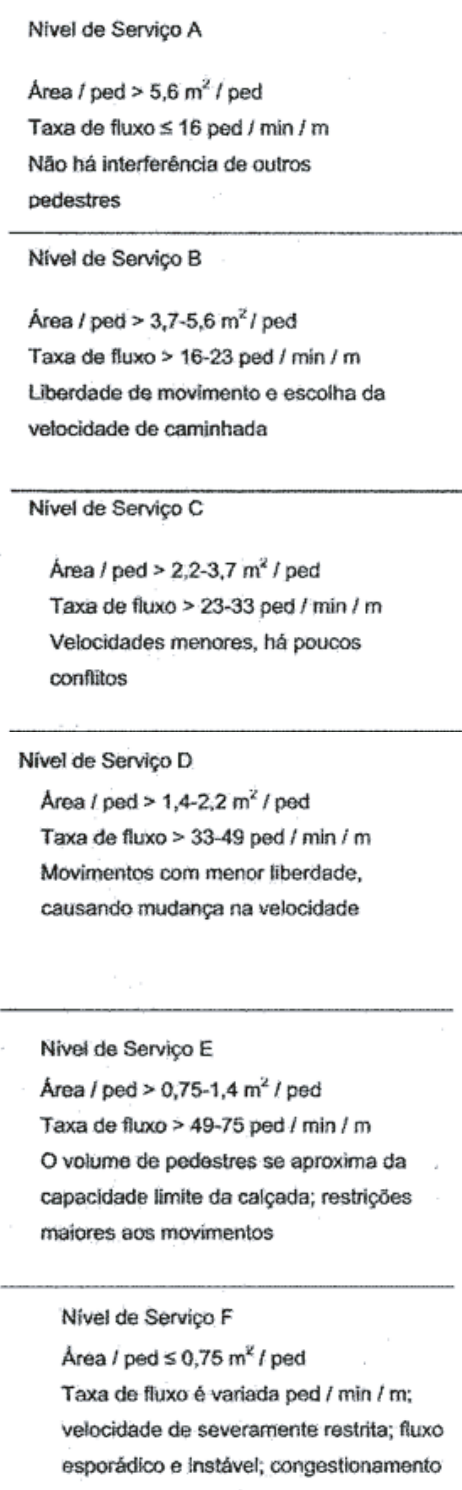
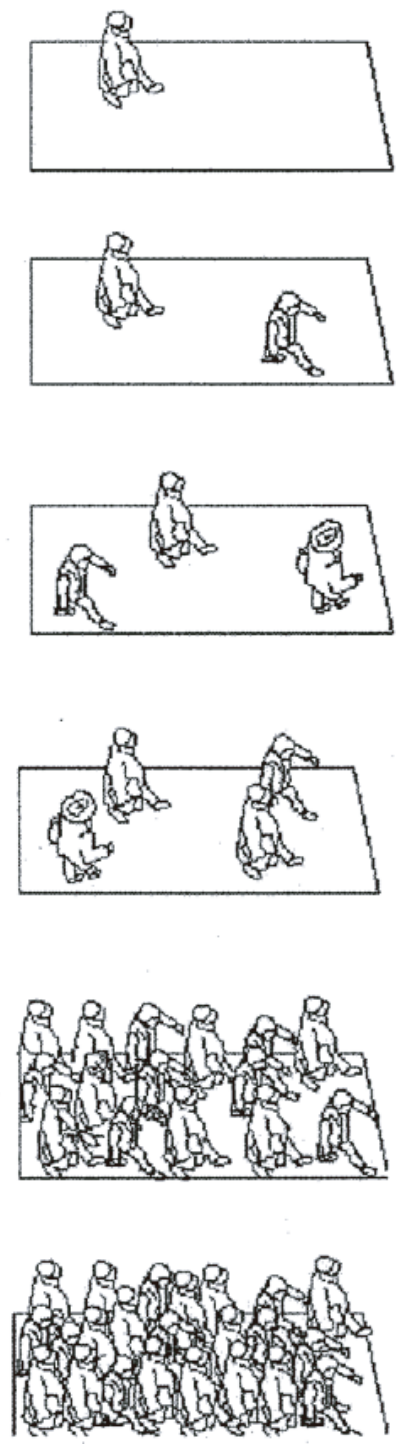

Tendo em vista que a média de fluxo atual era pequena nos três trechos, salvo nas ruas principais onde, ainda assim, o movimento não passa de 16 pedestres por minuto por metro, foram selecionados os níveis de serviço B e E com o objetivo de analisar situações próximas aos limites menor e maior, com a certeza de que a circulação de pedestres irá aumentar com o adensamento planejado. A equação utilizada está colocada na norma (ABNT, 2004), conforme consta a seguir:

$$
L=F / K+\sum i \geq 1,20
$$

onde:

L é a largura da faixa livre;

F é o fluxo de pedestres estimado ou medido nos horários de pico (pedestres por minuto por metro); 
$K=25$ pedestres por minuto;

$\sum$ i é o somatório dos valores adicionais relativos aos fatores de impedância.

Os valores adicionais relativos a fatores de impedância (i) são:

a) $0,45 m$ junto a vitrines ou comércio no alinhamento;

b) 0,25m junto a mobiliário urbano;

c) 0,25m junto à entrada de edificações no alinhamento.

Deste modo, para o Nível B obteve-se:

$\mathrm{F}=23$ pedestres/minuto/metro

- Sem comércio no alinhamento $\left(\sum \mathrm{i}=0,50\right)$

$\mathrm{L}=23 / 25+0,50=1,42 \mathrm{~m}$

- Com comércio no alinhamento $\left(\sum \mathrm{i}=0,95\right)$

$\mathrm{L}=23 / 25+0,95=1,87 \mathrm{~m}$

Para o Nível E temos:

$\mathrm{F}=75$ pedestres/minuto/metro

- Sem comércio no alinhamento $\left(\sum \mathrm{i}=0,50\right)$

$\mathrm{L}=75 / 25+0,50=3,50 \mathrm{~m}$

- Com comércio no alinhamento $\left(\sum \mathrm{i}=0,95\right)$

$\mathrm{L}=75 / 25+0,95=3,95 \mathrm{~m}$

Para o cálculo utilizando a densidade populacional prevista, partiu-se do princípio de que o passeio deve comportar todos os moradores do quarteirão ao mesmo tempo, de maneira segura, para que em uma situação de emergência ou evento não ocorram tumultos. Assim, foi adotada a quantidade de quatro pessoas por metro quadrado, que não proporciona grande liberdade ao caminhar, mas é uma medida segura no que diz respeito às aglomerações.

Deste modo, tendo como base o trabalho final de graduação de Custódio, foram selecionadas a média de densidade populacional menor e maior, 600 habitantes por hectare e 1400 habitantes por hectare, e foi calculada a largura ideal para comportar esta população de maneira segura ao longo de 100 metros, equivalente a um quarteirão. 
Tabela 2: Tabela comparativa de larguras de faixa livre. Fonte: Elaborado por Meire Nakamura.

Tabela 3: Tabela comparativa de larguras totais. Fonte: Elaborado por Meire Nakamura.
Assim temos, sendo $L$ a largura da faixa livre em metros,

$\mathrm{L} \times 100 \mathrm{~m}=100 . \mathrm{L} \mathrm{m}^{2}$

$$
\text { 100.L } \mathrm{m}^{2} \times 4 \text { pessoas } / \mathrm{m}^{2}=400 . \mathrm{L}
$$

- Para 600 hab/ha

400. $\mathrm{L}=600 \rightarrow \mathrm{L}=1,5 \mathrm{~m}$

- Para 1400 hab/ha

400.L $=1400 \rightarrow \mathrm{L}=3,5 \mathrm{~m}$

Para uma melhor visualização, os resultados dos dois métodos foram colocados na tabela:

\begin{tabular}{|c|c|c|c|}
\hline $\begin{array}{c}\text { Quantidade de } \\
\text { pedestres }\end{array}$ & \multicolumn{2}{|c|}{ Fluxo } & \multirow{2}{*}{ Densidade } \\
\hline \multirow{2}{*}{ Menor } & sem comércio & 1,42 & \multirow{2}{*}{1,50} \\
\cline { 2 - 3 } & com comércio & 1,87 & \multirow{2}{*}{3,50} \\
\hline \multirow{2}{*}{ Maior } & sem comércio & 3,50 & 3,95 \\
\cline { 2 - 3 } & com comércio & 3,50 \\
\hline
\end{tabular}

Através da tabela observa-se que não houve grandes discrepâncias nos resultados dos dois métodos. No entanto, é importante ressaltar que às medidas encontradas anteriormente ainda devem ser acrescidas as faixas de serviço, de acesso e a ciclofaixa.

Faixa de serviço: 0,75

Faixa de acesso: sem medida mínima, adotou-se 0,30 m com base em observações locais

Total a ser somado: $0,75+0,30+$ faixa livre $=1,05+$ faixa livre Sendo assim, a tabela com as larguras totais passa ser:

\begin{tabular}{|c|c|c|c|}
\hline $\begin{array}{c}\text { Quantidade de } \\
\text { pedestres }\end{array}$ & \multicolumn{2}{|c|}{ Fluxo } & \multirow{2}{*}{ Densidade } \\
\hline \multirow{2}{*}{ Menor } & sem comércio & 2,47 & \multirow{2}{*}{2,55} \\
\cline { 2 - 3 } & com comércio & 2,92 & \\
\hline \multirow{2}{*}{ Maior } & sem comércio & 4,55 & \multirow{2}{*}{4,55} \\
\cline { 2 - 3 } & com comércio & 5,00 & \\
\hline
\end{tabular}

Há ainda o acréscimo da ciclofaixa e da pista de veículos,

- Ciclofaixa: 1,80 m (não somado à calçada, pois fica no nível da rua)

- Pista de veículos: mínimo, segundo Mascaró (1989), é de 2,70 m para ruas residenciais e de 3,00 $\mathrm{m}$ para ruas principais 
Assim, as dimensões mínimas para largura de vias são:

- Para a menor quantidade de pedestres, incluindo-se a calçada, ciclofaixa e uma pista de veículos é de: $(2,50 \times 2)+$ $1,80+2,70=9,50 m$

- Para a maior quantidade de pedestres, incluindo-se a calçada, ciclofaixa e uma pista de veículos é de: $(4,55 \times 2)+$ $1,80+3,00=13,90 m$

Estes valores foram aplicados na região de acordo com o projeto de adensamento proposto. Assim, apesar de contar com as dimensões adequadas, considerou-se o adensamento proposto para a região, com as larguras calculadas de acordo com o possível fluxo e com a densidade populacional projetada foram obtidas as novas larguras ideais e aplicadas nas vias de acordo com os usos previstos, divididas em maior ou menor quantidade de pedestres.

Como exemplo, as novas medidas foram aplicadas na Rua Barão de Iguape, área que prevê a construção de várias unidades de habitação de interesse social - HIS - e por isso foram consideradas as medidas para maior quantidade de pedestres.

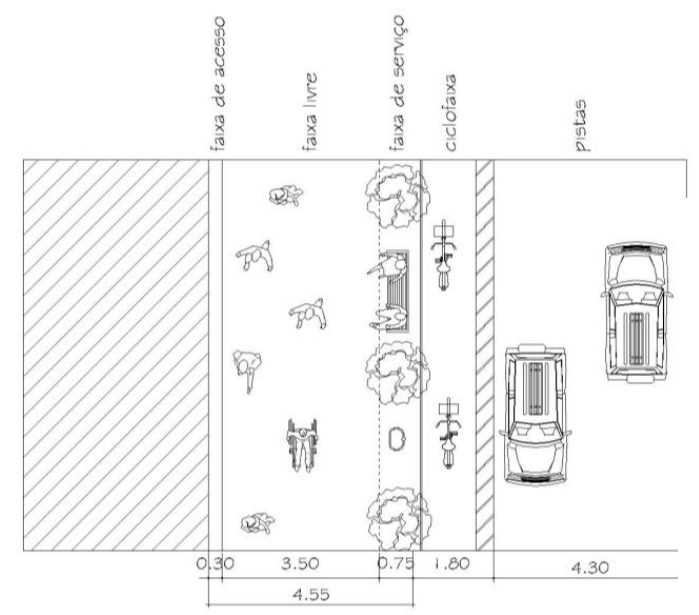

Figura 25 (Esquerda): Planta com novas larguras da Rua Barão de Iguape. Fonte: Elaborado por Meire Nakamura. Figura 26 (Direita): Corte com novas larguras da Rua Barão de Iguape. Fonte: Elaborado por Meire Nakamura.

Como conclusões principais, é importante observar que a normatização existente dá prioridade à acessibilidade técnica dos espaços, muitas vezes sem considerar as características locais, assim sendo, não garantem a mobilidade nem a qualidade dos passeios para os pedestres. Podem-se apontar possíveis razões para que isso ocorra, como a dificuldade de mensurar fatores próprios de cada usuário ou a complexidade das estimativas ao adicionar fatores simultaneamente, como o acesso à luz do sol, altura de edifícios, presença de vegetação, entre outros. Estabelecer regras de cálculos considerando-se estas situações resultaria num modelo extremamente complexo, frente à diversidade de cenários existentes em cada localidade. 
Os resultados obtidos apresentam suas ressalvas, como no caso do método de cálculo utilizando-se os fluxos, em que não é possível prever a dinâmica de circulação que poderá acontecer que pode ter como variáveis a presença de comércio e serviços, a eficiência do sistema de transporte coletivo, o uso de ciclovias e o quanto o pedestre se sentirá motivado a usar a caminhada no dia a dia. Com o uso do método de cálculo pela densidade, o dimensionamento é feito com base no máximo de pessoas que poderiam fazer uso do passeio simultaneamente, trata-se de uma situação limite, que pode ser questionada com relação aos espaços que ficariam subutilizados na maior parte do tempo, o contraponto pode ser justificado pelo uso comunitário do espaço público, com áreas de convivência, por exemplo.

Deste modo, frente à amplitude do tema, esta pesquisa teve como resultado uma pequena parcela do que envolve a acessibilidade e mobilidade dos espaços urbanos, através da proposição de medidas seguras e confortáveis para a circulação de pedestres. Esta proposição, no entanto, não considera fatores com certo caráter subjetivo como a percepção do espaço pelo usuário, tampouco o fazem as normas de acessibilidade estudada.

É importante avaliar esta complexidade existente nestas análises nas intervenções que ocorrem hoje nas cidades. A "bandeira da acessibilidade" muitas vezes cria uma falsa ideia de resolução dos problemas e na maioria das vezes mascara o real problema que deve ser encarado nas grandes cidades. 
Aplicação dos Métodos 2 e 3:

Adensamento urbano com qualidade ambiental, mobilidade e acessibilidade

\begin{abstract}
Com o objetivo de preencher as lacunas deixadas na primeira pesquisa aqui apresentada, houve a aplicação de alguns critérios baseados nos métodos de referência aqui descritos anteriormente. Tendo como base Michael Southworth (Designing the Walkable City) e Júlio Pozueta (Movilidad y Planeamento Sostenible) elaborou-se um método que procurou avaliar fatores de influência no conforto e percepção do pedestre, com objetivo de gerar diretrizes de projeto e consequentemente melhoria dos espaços urbanos.
\end{abstract}

Em paralelo, foram obtidas informações sobre as áreas de estudo a partir do levantamento do grupo de pesquisa do LABAUT. Em seguida, foram estabelecidos os critérios a serem utilizados na análise das vias. Tais critérios foram determinados com base no estudo bibliográfico, a partir do qual se definiu os parâmetros relevantes para se estimular uma "mobilidade sustentável"12. Os critérios aplicados nas análises foram:

\section{CICLOVIAS}

Pode-se dizer que, junto com a opção de ir a pé, a bicicleta é o meio de transporte mais sustentável, pois além de não poluir o meio ambiente, promove a saúde de seu condutor. Esse critério vê a presença de ciclovia, ciclorrota ou ciclofaixa nas áreas de estudo:

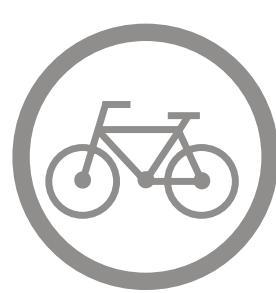

- Melhor situação (verde): presença de infraestrutura ao ciclista, como ciclofaixa e ciclovia.

- Situação regular (amarelo): presença de ciclorrota na via, que indica a possibilidade de ciclistas na área.

- Pior situação (vermelho) indica ausência de qualquer tipo de infraestrutura ao ciclista.
[12] Parte deste método aqui apresentado foi aplicado na Iniciação Científica Adensamento Urbano com Qualidade Ambiental, mobilidade e acessibilidade na República e Bela Vista, da aluna Julia Benitez Galves. 


\section{ESTACIONAMENTOS}

O estacionamento, tanto na rua quanto como serviço, estimula o deslocamento por carro. Não apenas, quando o carro é estacionado na rua, ao lado da calçada, torna-se um obstáculo ao pedestre, além de promover uma percepção negativa do espaço:

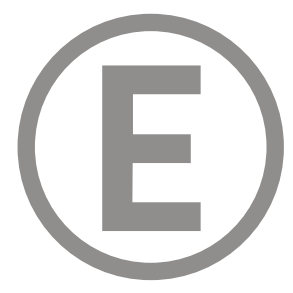

- Melhor situação (verde): ausência de estacionamento ao longo da via.

- Situação regular (amarela): permite-se que os carros estacionem em pelo menos um lado da via.

- Pior situação (vermelho): carros estacionam dos dois lados da via e há presença de estacionamentos na área

\section{USO MISTO DO SOLO}

É presente em praticamente toda a bibliografia a importância do uso do solo misto como um fator de redução do meio de transporte motorizado. Um bairro predominantemente residencial determina que seus moradores devam se deslocar para ter acesso a serviços básicos, desde supermercado, padaria, até mesmo ao local de trabalho e estudo. Uma área em que o uso do solo é bem variado promove, portanto, uma menor necessidade de deslocamento de longas distâncias para fazer o necessário da rotina diária:

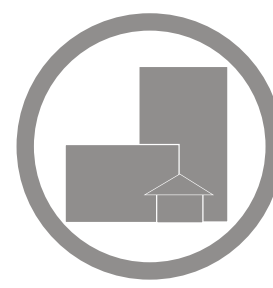

- Melhor situação (verde): diversos usos do solo na área.

- Situação regular (amarelo): pelo menos dois tipos de uso do solo.

- Pior situação (vermelho): apenas um uso do solo

\section{PRESENÇA DE ATRATIVOS VERDES}

A presença de verde no percurso é importante tanto na questão sensorial, na percepção do espaço, como na questão do conforto térmico, ao auxiliar na redução da temperatura.

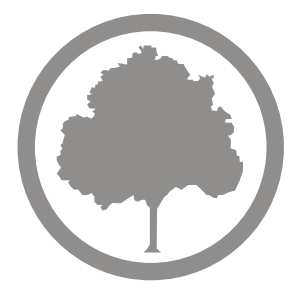

- Melhor situação (verde): é visível uma grande predominância de vegetação na área.

- Situação regular (amarelo): há presença de vegetação na área.

- Pior situação (vermelho): a vegetação é praticamente ausente na área 


\section{PROXIMIDADE AOS MEIOS DE TRANSPORTES COLETIVOS}

Considera-se razoável que a distância de acesso ao ponto de ônibus, a pé, seja de $300 \mathrm{~m}$ (aproximadamente 5 minutos de caminhada). Esse valor aumenta para $500 \mathrm{~m}$ para acessar o transporte público sobre trilhos. A proximidade à meios de transporte é relevante já que isso pode promover um estimulo na escolha deste sobre o transporte privado:

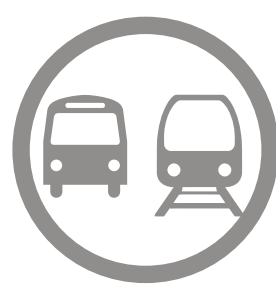

- Melhor situação (verde): distância ao ponto de ônibus 'de até $150 \mathrm{~m}$ da estação de metrô de até $250 \mathrm{~m}$.

- Situação regular (amarela): distância ao ponto de ônibus de até $300 \mathrm{~m}$, da estação de metrô de até $500 \mathrm{~m}$.

- Pior situação (vermelha): distância ao ponto de ônibus superior à $300 \mathrm{~m}$, da estação de metrô superior à $500 \mathrm{~m}$.

\section{CALÇADAS}

As calçadas em São Paulo têm sido cada vez mais desumanizadas, em uma cidade que a prioridade é o carro. Para tal critério, será avaliada sua situação quanto à adequação a norma da ABNT, que visa um mínimo de 1,20m de faixa livre, a partir da fórmula $L=F / K+\sum i \geq 1,20$ :

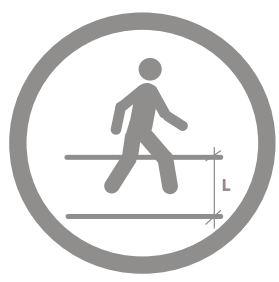

- Melhor situação (verde): calçada dimensionada acima do mínimo necessário $+10 \mathrm{~cm}$.

- Situação regular (amarelo): calçada dimensionada até mínimo necessário $+10 \mathrm{~cm}$.

- Pior situação (vermelho): calçada dimensionada abaixo do mínimo necessário.

\section{VELOCIDADE DAS VIAS}

O leito carroçável é um obstáculo ao pedestre, ainda mais na cultura urbana brasileira em que o carro tem prioridade. Atrelado a isso, quanto maior a velocidade permitida aos meios motorizados, menos é a segurança do pedestre:

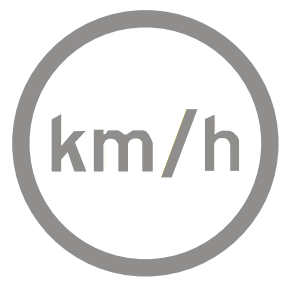

- Melhor situação (verde): limite de $30 \mathrm{~km} / \mathrm{h}$.

- Situação regular (amarelo): limite de $40 \mathrm{~km} / \mathrm{h}$

- Pior situação (vermelho): limite de $60 \mathrm{~km} / \mathrm{h}$ ou mais 


\section{PERCEPÇÃO DO ESPAÇO}

A sensação do espaço transmitida ao pedestre na interação pode ser avaliada a partir da situação da calçada, abóboda de céu visível a nível da via, fluxo de carros, e a presença de atrativos verdes:

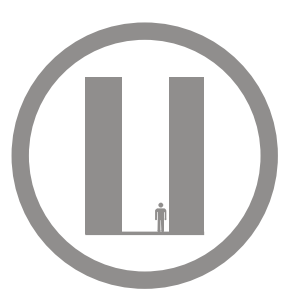

- Melhor situação (verde): presença de muito verde, calçada de tamanho adequada, recuo dos prédios permitindo uma ampla visão do céu, baixo fluxo de carros.

- Situação regular (amarelo): presença regular de verde, fluxo de carros médio/alto, visão da abóboda celeste afetada pelos edifícios.

- Pior situação (vermelho): ausência de verde, calçada subdimensionada, visão restringida do céu, alto fluxo de carros

\section{FLUXO DE CARROS}

\section{Classificação:}

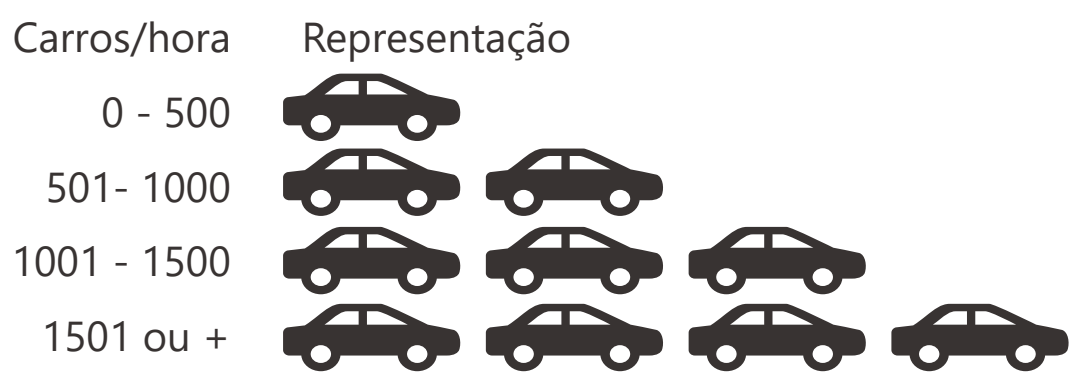

\section{FLUXO DE PEDESTRES}

\section{Classificação:}

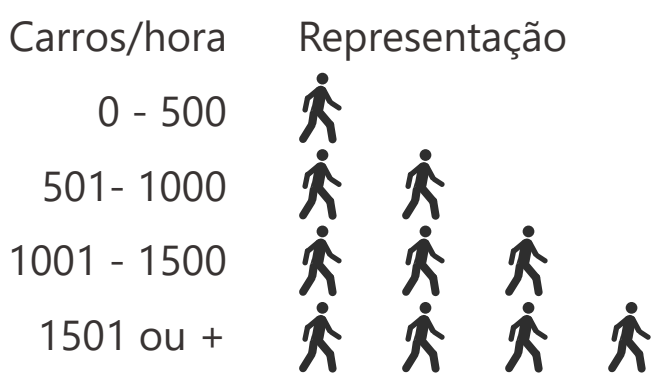

Definido os critérios, iniciou-se o estudo das áreas da Bela Vista e da República direcionado à questão da mobilidade e acessibilidade. Foi feito o levantamento do fluxo aproximado de carros e pedestres in loco, e elaborado mapas destes fluxos. Também foi feito o levantamento fotográfico das áreas de estudo, tendo em vista a questão da percepção do espaço. Com o uso da lente fisheye, fotos de $180^{\circ}$ foram tiradas para captar a abóboda de céu visível em cada via da área de estudo. Fotos da via foram tratadas para ressaltar a presença de verde em cada uma das ruas. Foram levantados os 
dados relativos a cada um dos critérios de análise da mobilidade, ou seja, em uma tabela foram esquematizadas as informações quanto ao fluxo, atrativos verdes, estacionamentos na região, proximidade aos meios de transporte, presença de infraestrutura ao ciclista, dimensionamento das calçadas (em função do fluxo de pessoas), velocidade da via, percepção do espaço, fluxo de pessoas e de carros, dentro de critérios discutidos no escopo da pesquisa.

O cálculo de dimensionamento de calçadas também foi feito na tabela (ficha síntese), para determinar qual calçada estava subdimensionada. A próxima etapa foi aplicação dos critérios para analisar a situação atual das áreas de estudo quanto a sua mobilidade e qualidade ambiental. Para uma compreensão mais direta dos critérios em cada via, foi determinada uma escala de situação boa (verde), regular (amarelo) e ruim (vermelho). Assim, uma ficha de cada uma das vias, de cada uma das áreas, foi feita, classificando quanto a cada um dos critérios. Por fim, definiu-se um novo desenho urbano, no caso das áreas em que a situação atual não fosse a desejável.

A seguir, panorama geral das áreas levantadas e exemplo de ficha síntese das avaliações em trechos selecionados:

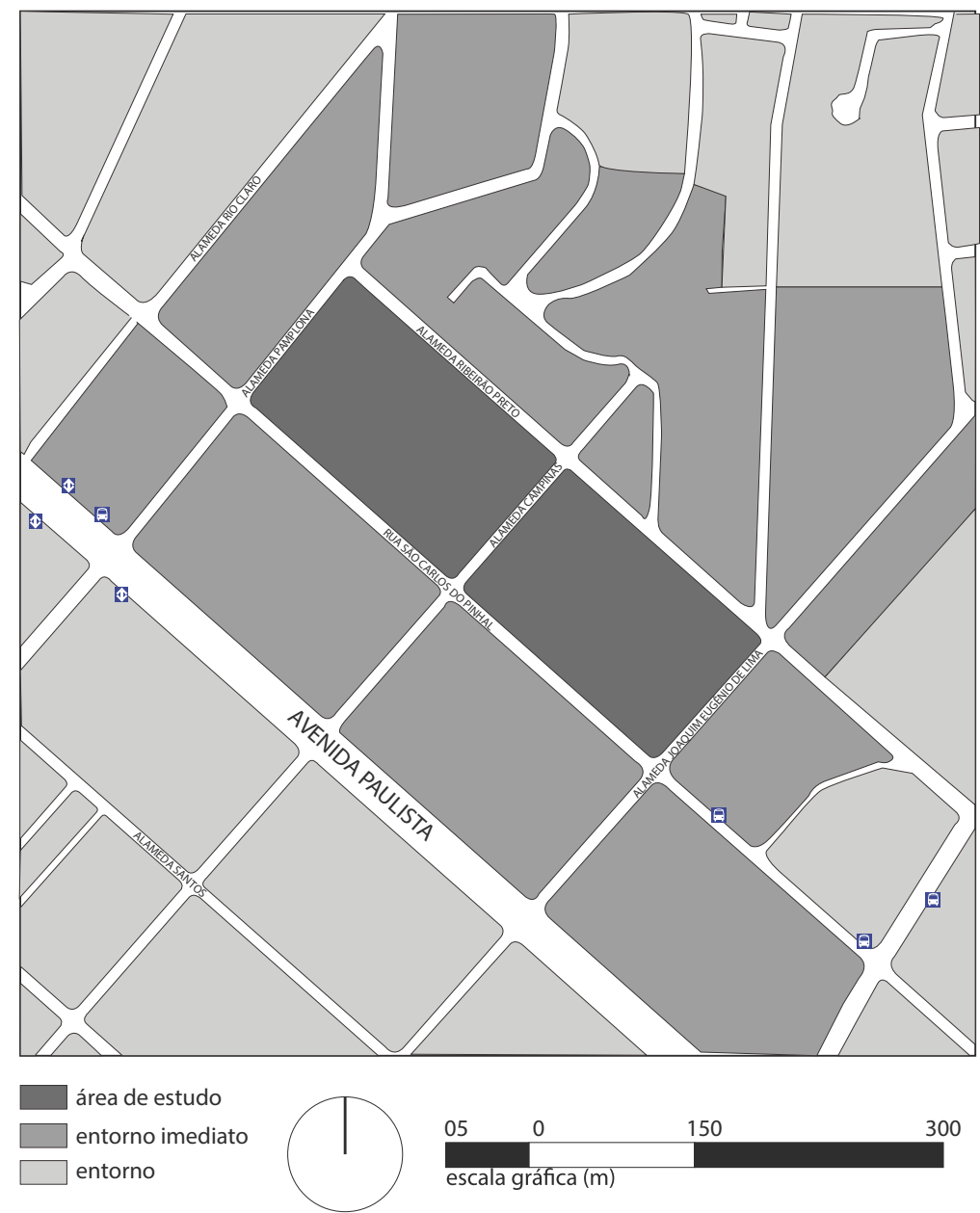

Figura 27: Bela Vista: Mapa área. Fonte: Elaborado por Julia Galves. 
Figura 28: Ficha síntese do levantamento feito na Alameda

Campinas - Bela Vista. Fonte:

Elaborado por Júlia Galves.
No caso da Bela Vista, foram levantados 07 trechos das ruas em análise. A seguir, exemplo de uma das ruas analisadas dentro dos critérios já expostos:

Bela Vista: Alameda Campinas

1
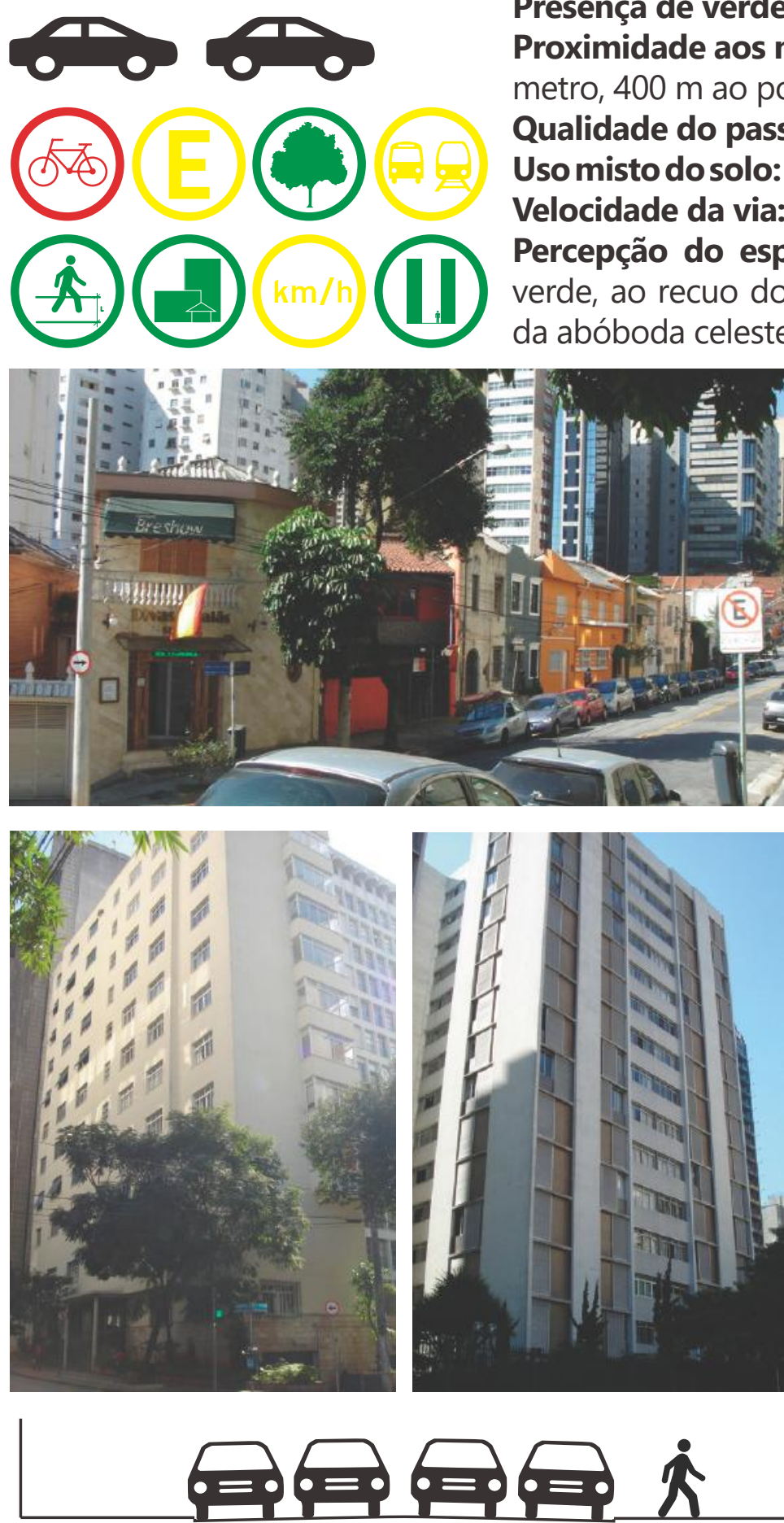

(E)
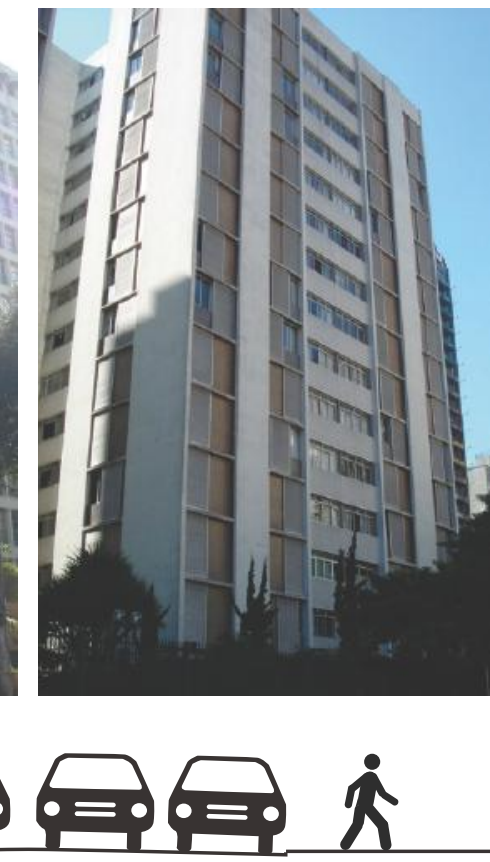

(E)
Ciclovia: não há nenhuma infraestrutura ao ciclista

Estacionamento: nos dois lados da via

Presença de verde: bom

Proximidade aos meios de transporte: $550 \mathrm{~m}$ da estação de metro, $400 \mathrm{~m}$ ao ponto de ônibus

Qualidade do passeio: calçadas largas 3,5m em média

Uso misto do solo: presença de residência, serviço e escritórios Velocidade da via: $40 \mathrm{~km} / \mathrm{h}$

Percepção do espaço: bom, devido à densa presença de verde, ao recuo dos prédios que permite uma melhor visão da abóboda celeste, ao baixo fluxo de carros da rua.
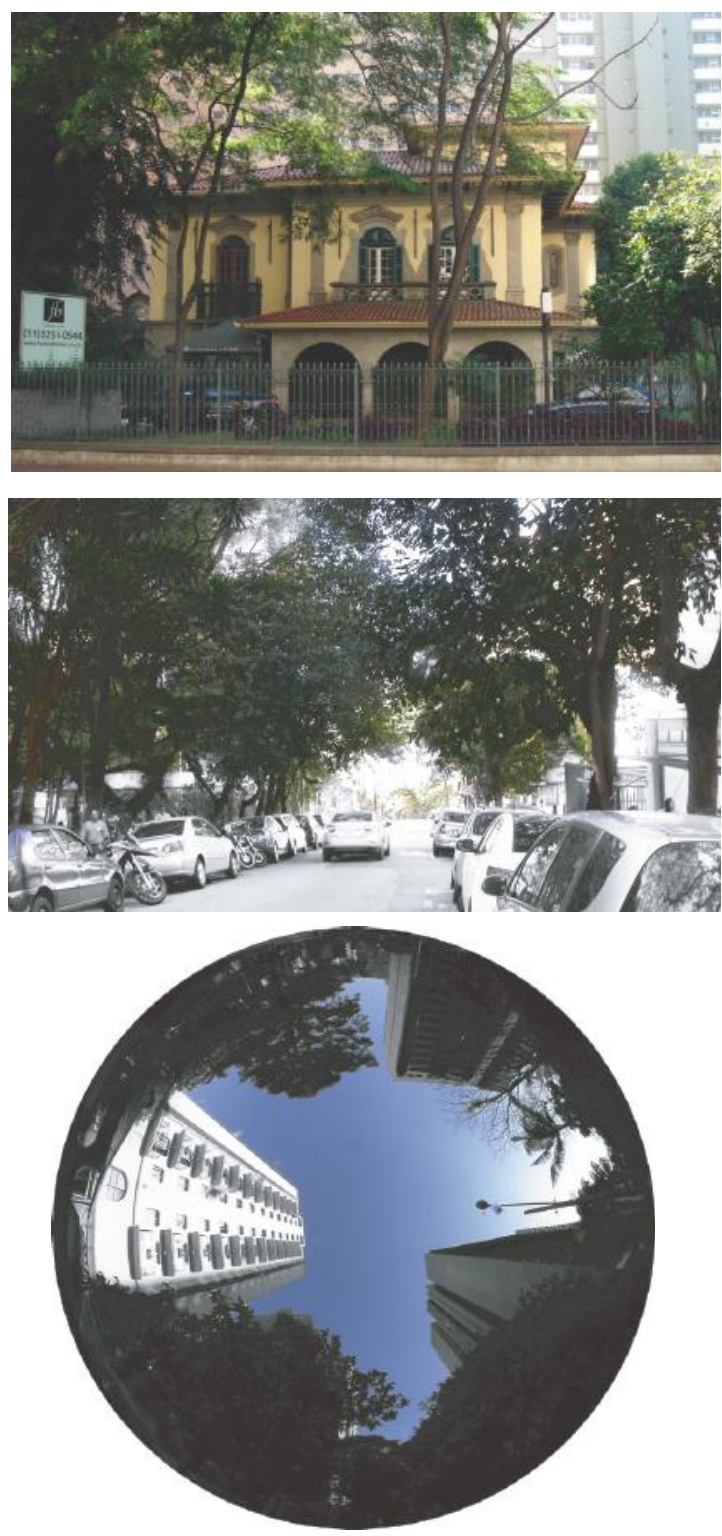
No caso da República, a área de estudo compreende os quarteirões limitados pelas ruas dos Timbiras, dos Guianases, Vitória e Conselheiro Nébias, cortada pela Rua Aurora. A seguir serão apresentados os resultados para a Rua dos Timbiras.

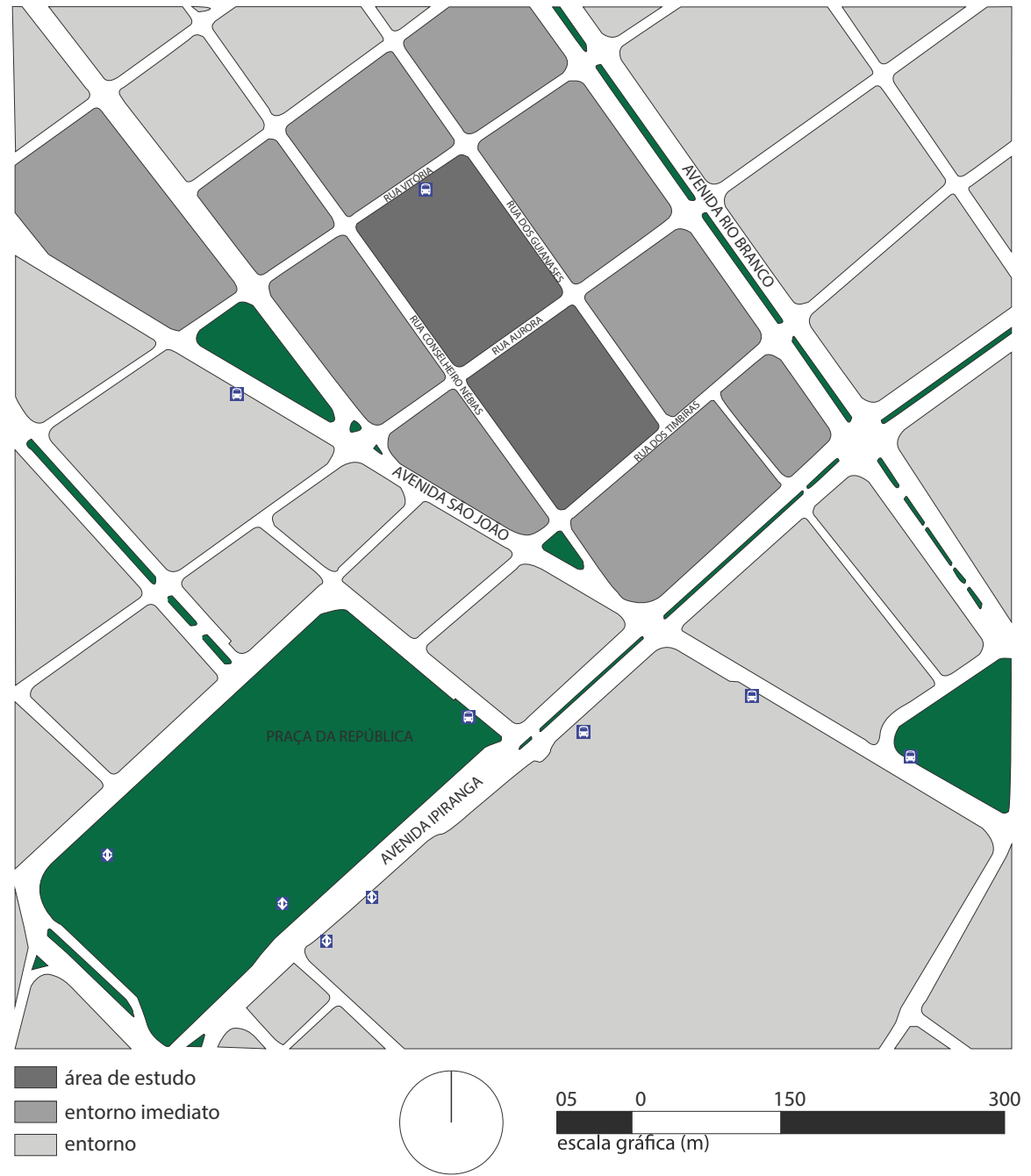

Figura 29 (Ao lado):

República: Mapa da área e entorno. Fonte: Elaborado por Julia Galves.

Figura 30 (À baixo):

República: Ficha síntese do levantamento feito na Rua Timbiras - República. Fonte: Elaborado por Júlia Galves.

República: Rua dos Timbiras

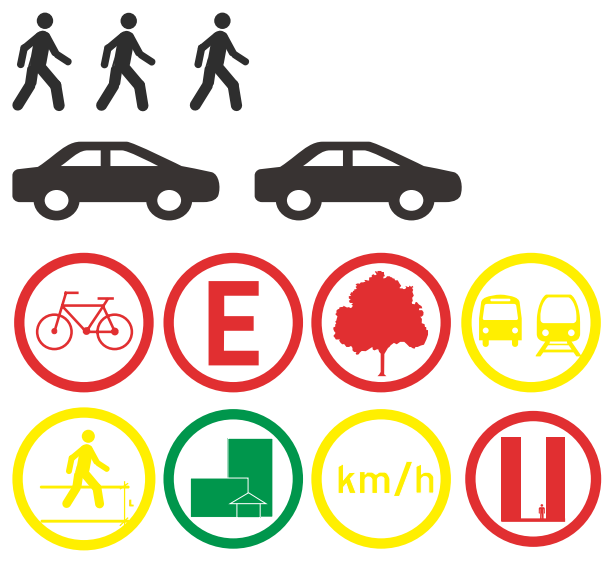

Ciclovia: não há nenhuma infraestrutura ao ciclista Estacionamento: estacionamento permitido dos dois lados da via, três estacionamentos na área

Presença de verde: dois ou três arbustos

Proximidade aos meios de transporte: $550 \mathrm{~m}$ da estação de metro, $250 \mathrm{~m}$ ao ponto de ônibus

Qualidade do passeio: calçadas de 2,52m em média

Uso misto do solo: diversos usos

Velocidade da via: $40 \mathrm{~km} / \mathrm{h}$

Percepção do espaço: ruim, devido à insignificante presença de verde, da inexistência de um recúo dos prédios, resultando em uma baixa área de abóboda celeste visível. 

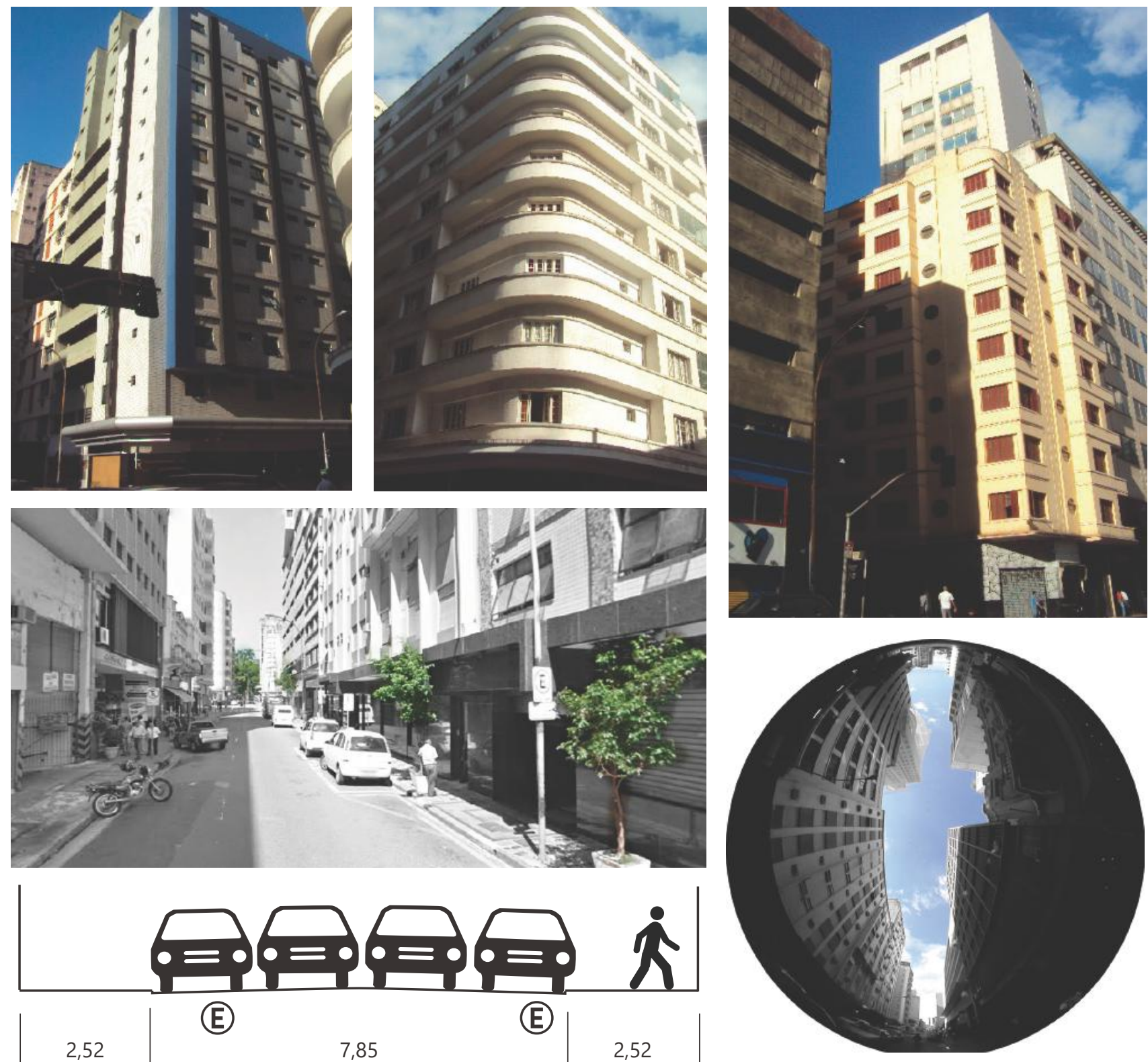

Figura 30 (Continuação): República: Ficha síntese do levantamento feito na Rua Timbiras - República. Fonte: Elaborado por Júlia Galves.

Tabela 4: Fluxo de carros e pedestres na Bela Vista. Fonte: Elaborado por Júlia Galves.
Os fluxos de carros e pedestres foram avaliados a partir dos estudos desenvolvidos no TFG, descrito anteriormente.

\begin{tabular}{|l|c|c|}
\hline \multirow{2}{*}{\multicolumn{2}{|c|}{ ReLA VISTA }} \\
\cline { 2 - 3 } & \multicolumn{2}{c|}{ Fluxos } \\
\cline { 2 - 3 } & carro/h & pedestre/h \\
\hline Rua Pamplona & 705 & 630 \\
\hline Al. Ribeirão Preto (1) & 435 & 150 \\
\hline Al. Ribeirão Preto (2) & 630 & 120 \\
\hline Al. Campinas & 570 & 255 \\
\hline R. São Carlos do Pinhal & 1260 & 465 \\
\hline Al. Joaquim Eugênio & 1575 & 465 \\
\hline
\end{tabular}




\begin{tabular}{|l|c|c|}
\hline \multirow{2}{*}{\multicolumn{2}{c|}{ RePÚB }} & \multicolumn{2}{c|}{ Fluxos } \\
\cline { 2 - 3 } & carro/h & pedestre/h \\
\hline Rua dos Timbiras & 510 & 1140 \\
\hline Rua Guaianases & 60 & 960 \\
\hline Rua Aurora & 240 & 1620 \\
\hline Rua Vitória & 840 & 660 \\
\hline Rua Conselheiro Nébias & 960 & 480 \\
\hline Av. São João & 1320 & 4200 \\
\hline Av. Ipiranga & 1260 & 4440 \\
\hline
\end{tabular}

Tabela 5 (Ao lado): Fluxo de carros e pedestres na República. Fonte: Elaborado por Júlia Galves.

Tabela 6 (À baixo):

Levantamento dos passeios - Bela Vista. Fonte: Elaborado por Júlia Galves.

\begin{tabular}{|c|c|c|c|c|c|c|c|c|c|}
\hline \multicolumn{10}{|c|}{ BELA VISTA } \\
\hline Rua & $\begin{array}{c}\text { Fluxo } \\
\mathrm{ped} / \mathrm{min}\end{array}$ & $\begin{array}{l}\text { Nível de } \\
\text { serviço }\end{array}$ & $\mathrm{F}$ & $\begin{array}{l}\text { Faixa } \\
\text { livre (L) }\end{array}$ & $\begin{array}{c}\text { Faixa de } \\
\text { acesso }\end{array}$ & $\begin{array}{l}\text { Faixa de } \\
\text { serviços }\end{array}$ & $\begin{array}{c}\text { Dimensão } \\
\text { mínima }\end{array}$ & $\begin{array}{c}\text { Tamanho } \\
\text { atual }\end{array}$ & $\begin{array}{l}\text { Folga } \\
\text { calçada }\end{array}$ \\
\hline Rua Pamplona & 10,5 & $A$ & 16 & 1,2 & 0,3 & 0,75 & 2,25 & 3,85 & 1,6 \\
\hline Al. Ribeirão Preto (1) & 2,5 & $A$ & 16 & 1,2 & 0,3 & 0,75 & 2,25 & 3,45 & 1,23 \\
\hline Al. Ribeirão Preto (2) & 2 & $A$ & 16 & 1,2 & 0,3 & 0,75 & 2,25 & 2,88 & 0,63 \\
\hline Al. Campinas & 4,25 & $A$ & 16 & 1,2 & 0,3 & 0,75 & 2,25 & 3,5 & 1,25 \\
\hline R. São Carlos do Pinhal & 7,75 & A & 16 & 1,2 & 0,3 & 0,75 & 2,25 & 3,29 & 1,04 \\
\hline Al. Joaquim Eugênio & 7,75 & A & 16 & 1,2 & 0,3 & 0,75 & 2,25 & 3,5 & 1,25 \\
\hline
\end{tabular}

\begin{tabular}{|l|c|c|c|c|c|c|c|c|c|}
\hline \multicolumn{1}{|c|}{ Rua } & $\begin{array}{c}\text { Fluxo } \\
\text { ped/min }\end{array}$ & $\begin{array}{c}\text { Nível de } \\
\text { serviço }\end{array}$ & $\mathrm{F}$ & $\begin{array}{c}\text { Faixa } \\
\text { livre (L) }\end{array}$ & $\begin{array}{c}\text { Faixa de } \\
\text { acesso }\end{array}$ & $\begin{array}{c}\text { Faixa de } \\
\text { serviços }\end{array}$ & $\begin{array}{c}\text { Dimensão } \\
\text { mínima }\end{array}$ & $\begin{array}{c}\text { Tamanho } \\
\text { atual }\end{array}$ & $\begin{array}{c}\text { Folga } \\
\text { calçada }\end{array}$ \\
\hline Rua dos Timbiras & 19 & $\mathrm{~B}$ & 23 & 1,42 & 0,3 & 0,75 & 2,47 & 2,52 & 0,05 \\
\hline Rua Guaianases & 16 & $\mathrm{~A}$ & 16 & 1,2 & 0,3 & 0,75 & 2,25 & 2,79 & 0,54 \\
\hline Rua Aurora & 27 & $\mathrm{C}$ & 33 & 1,82 & 0,3 & 0,75 & 2,87 & 2,61 & $-0,27$ \\
\hline Rua Vitória & 11 & $\mathrm{~A}$ & 16 & 1,2 & 0,3 & 0,75 & 2,25 & 3,12 & 0,87 \\
\hline Rua Conselheiro Nébias & 8 & $\mathrm{~A}$ & 16 & 1,2 & 0,3 & 0,75 & 2,25 & 2,53 & 0,28 \\
\hline
\end{tabular}

Com base nos resultados modificações foram propostas com o objetivo de adequar as vias dentro dos critérios sugeridos. A ilustração abaixo, exemplo de alteração sugerida na Rua Aurora:
Tabela 7: Levantamento dos passeios - República. Fonte: Elaborado por Júlia Galves.

- Fluxo de pedestres in loco: 1620 pedestres/hora $=27$ pedestres/minuto

- Nível de serviço considerado C: fluxo de $23 \leq \mathrm{F} \leq 33 \mathrm{ped} / \mathrm{min}$ considera-se então $\mathrm{F}=33 \mathrm{ped} / \mathrm{min}$

- Dimensão média da calçada, situação atual: 2,61m

- Dimensão mínima da faixa livre pela NBR:L=F/K+ $i \geq 1,20 ; K=25$; $\sum i=0,5 \mathrm{~m} L=33 / 25+0,5=1,82$ somando $1,05 \mathrm{~m}$ da faixa de serviço $(0,75 \mathrm{~m})$ e de acesso $(0,3 \mathrm{~m})$

TOTAL MINIMO DE CALÇADA: 2,87m; a calçada atual é subdimensionada. 
Figura 31: Sugestão de modificação da via. Fonte: Elaborado por Julia Galves.
No novo desenho da rua Aurora, além do redimensionamento da calçada (que toma parte do leito carroçável para sua expansão), é proposta uma ciclofaixa, para estimular esse meio de transporte sustentável. Por fim, sugere-se também o plantio de verdes, importante para a melhoria da percepção do espaço.
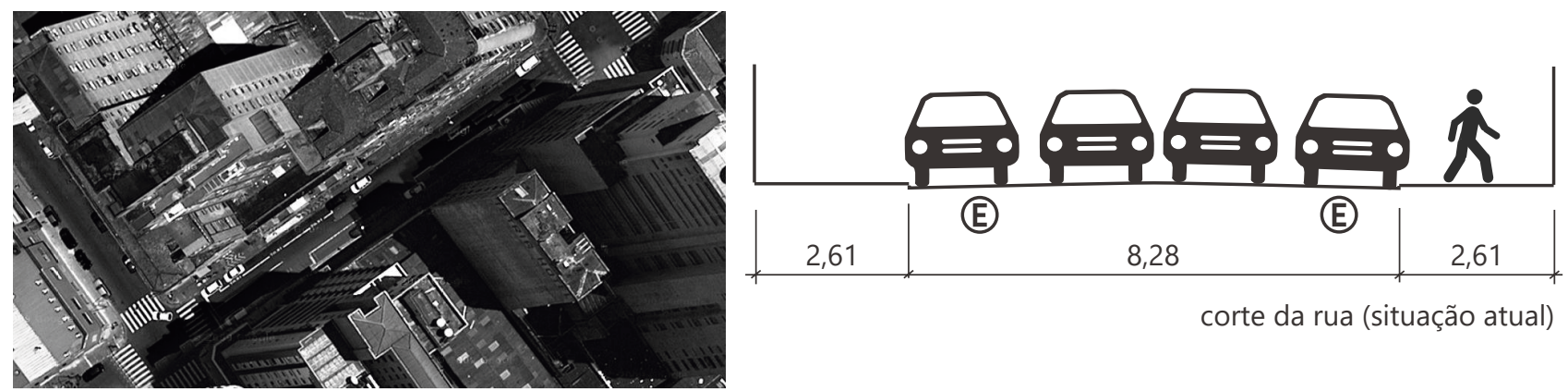

corte da rua (situação atual)
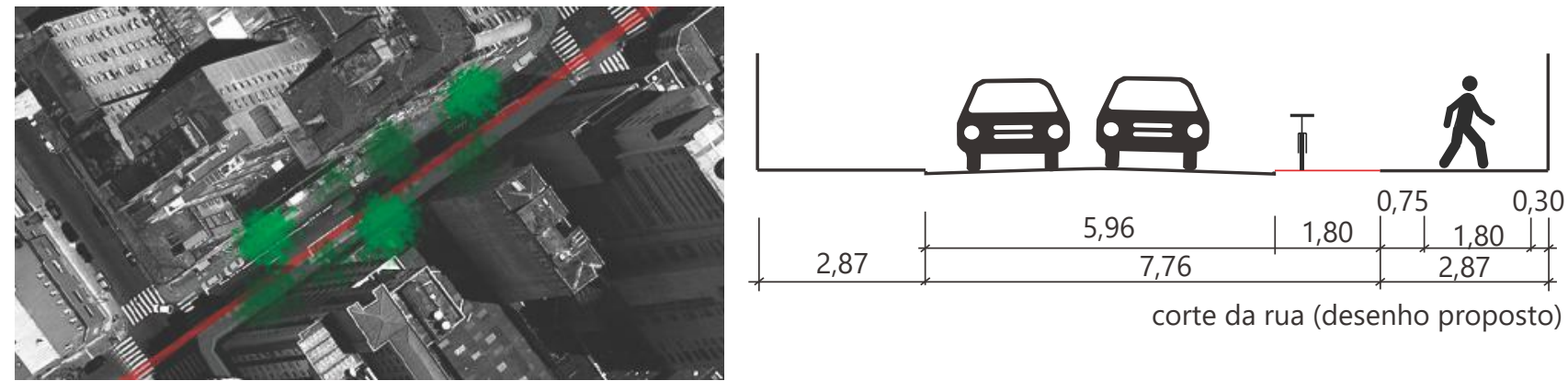

corte da rua (desenho proposto)

A partir de uma média dos critérios avaliados em cada rua, chegouse a classificação geral década uma das áreas de estudo:

\section{Bela Vista}
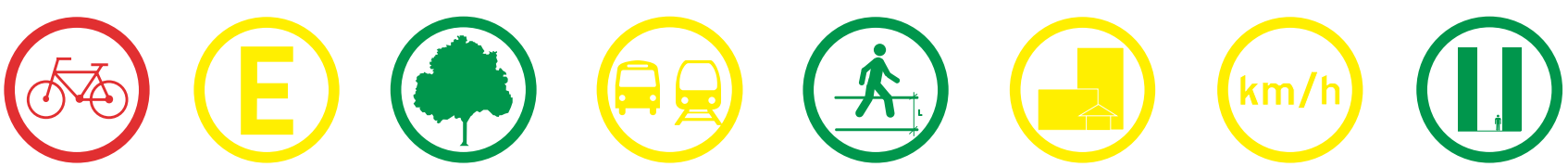

Os critérios de análise atribuídos a região da Bela Vista são, de maneira geral, de situação regular. As vias de menores fluxos de carro, que promovem, portanto, uma sensação melhor ao pedestre quanto à segurança são, também, aquelas em que o uso do solo é predominantemente residencial. As vias com maiores fluxos (Joaquim Eugênio, São Carlos do Pinhal), coincidentemente são as menos arborizadas da área, e a junção desses fatores faz com que a percepção do espaço nessas vias seja regular. Entretanto, de maneira geral, a área é muito arborizada, com ampla visão do céu, que promove melhor bem-estar ao pedestre. Por uma questão de sensação visual, a percepção é então classificada como boa.

República
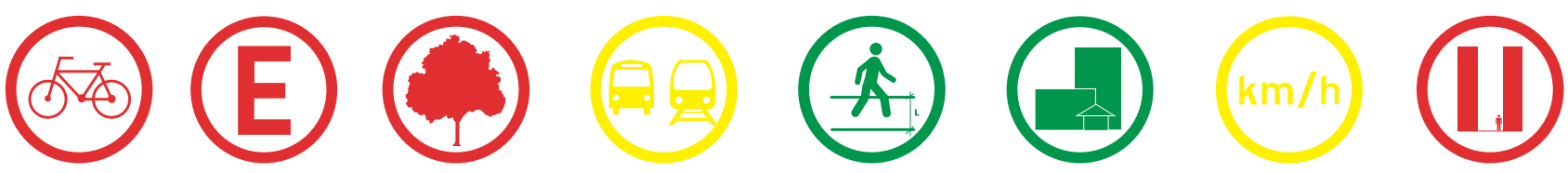
Os critérios na República são avaliados, em geral, de forma negativa. Destaca-se como positivo o uso de solo altamente misto, em que praticamente toda edificação apresenta mais de um uso. Entretanto, a insignificante presença de verde, a inexistência de recuos entre edificações, resultando em uma baixa área de céu visível, unida ao alto fluxo de pedestres, acaba conferindo à região uma percepção de espaço negativa.

A percepção do espaço, para esta pesquisa, baseou-se principalmente na questão visual do ambiente. Assim, fatores como a presença de verde, área de céu visível, uso do solo, fluxo de pedestres e de carros foram os fatores mais relevantes para a classificação. Deve-se atentar ao fato de que as duas áreas de estudo são muito diferentes, gerando análises e percepções opostas. A Bela Vista está localizada em uma área mais acidentada da cidade, em um local de renda mais alta. As edificações, apesar de altas, apresentam recuos, promovendo um "respiro" entre prédios e, portanto, permitindo uma maior ventilação e maior visão do céu. Não apenas, a área apresenta uma grande presença de verde, com árvores altas, de copa densa. Por essa questão visual a Bela Vista é classificada positivamente.

Na República, a situação é oposta: os prédios altos não apresentam recuos, nem entre si quanto entre a calçada, o que gera "cânions" urbanos, reduzindo a ventilação e a visão da abóboda celeste. O verde é praticamente ausente, aparecendo apenas em pequenos arbustos. Por essa razão, o bairro central é classificado negativamente. É interessante notar o quanto o verde faz diferença na avaliação da percepção. Como exemplo, temos a Rua Vitória, na República, que, por apresentar um "respiro" na quadra com um lote vazio, e a presença de uma grande árvore, já conferiu à rua a classificação regular de percepção do espaço. O mesmo ocorre na Al. Joaquim Eugênio, na Bela Vista. Nessa área, onde praticamente todas as vias foram classificadas positivamente pelo abundante verde, a alameda que corta a Avenida Paulista é pouco arborizada e apresenta um fluxo intenso de carros, resultando numa classificação regular de percepção do espaço. Na Rua São Carlos do Pinhal, que também apresenta pouco verde e muito fluxo de carro, acontece o mesmo. Em um urbanismo que foi consolidado para o automóvel, a via muitas vezes é repelente ao pedestre. Sendo esse agente um dos pilares da mobilidade sustentável, é preciso readaptar as vias para atrair o pedestre. Assim, a percepção do espaço é uma ferramenta essencial, pois avalia a questão do contexto do caminho.

Nesta pesquisa considerou-se a percepção do espaço relacionada aos critérios estabelecidos quantificados durante as medições. Os pedestres não foram entrevistados. 


\author{
Aplicação dos Métodos 2, 3 e 4: \\ Funções e atividades da habitação. Áreas externas: Expectativas e \\ necessidades de conforto e bem estar
}

[13] Neste contexto também foi desenvolvido, como parte da pesquisa, o projeto de pesquisa, com apoio da FAPESP, intitulado Avaliação Ergonômica das funções e atividades da Habitação: Áreas externas Expectativas e Necessidades de conforto, bem estar e autonomia de idosos aptos (saudáveis), da aluna Isabela

\begin{abstract}
A participação no Projeto Temático FAPESP (ref. processo 2010/10189-5): Biometeorologia Humana: análise dos efeitos da poluição atmosférica e mudanças climáticas em população geriátrica em São Paulo proporcionou a possibilidade de ampliação e aplicação do método descrito anteriormente e também utilização método desenvolvido pelo Departamento de Planejamento de Nova lorque, já apresentado aqui nesta tese. O objeto da pesquisa foi a avaliação ergonômica - acessibilidade e mobilidade - das áreas externas da habitação focada às necessidades de idosos aptos e o objetivo principal da pesquisa foi avaliar a qualidade ergonômica dos espaços externos da habitação ${ }^{13}$.
\end{abstract}

Além da avaliação ergonômica, o fato da pesquisa se desenvolver de forma interdisciplinar, não só com outras áreas do conforto ambiental, destacando o conforto térmico, mas também com a FMUSP - Faculdade de Medicina, Escola Politécnica e IAG USP - Instituto de Astronomia, Geofísica e Ciências Atmosféricas, propiciou a oportunidade de incorporar novas variáveis no processo de avaliação ergonômica.

A partir da seleção de 06 residências de idosos foram estabelecidos trajetos no entorno das mesmas (entrevistas com os usuários das residências) com o objetivo de circunscrever o percurso mais rotineiro do idoso. As habitações selecionadas estavam localizadas: no Rio Pequeno, na Aclimação, no Brooklin Novo, na Consolação, no Alto de Pinheiros e na Freguesia do Ó. Após uma avaliação prévia do entorno de cada residência, foram escolhidos dois locais para visitas de campo, aplicação de fichas e produção de desenhos: o entorno da R. da Consolação, que fica no bairro Consolação, e os arredores da R. Dr. Estevão Montebelo, situada no bairro da Freguesia do Ó.

Com esta análise e os percursos definidos realizaram-se as análises ergonômicas baseadas nos critérios mostrados no trabalho anterior (Adensamento urbano com qualidade ambiental, mobilidade e acessibilidade). Nesta primeira etapa foram levantados os dados relativos a cada um dos critérios de análise: quanto ao fluxo, atrativos verdes, estacionamentos na região, proximidade aos meios de transporte, presença de infraestrutura ao ciclista, dimensionamento das calçadas (em função do fluxo de pessoas), 
velocidade da via, percepção do espaço, fluxo de pessoas e de carros, dentro de critérios discutidos no escopo da pesquisa.

Além destes levantamentos, houve a aplicação do método desenvolvido pelo Departamento de Planejamento de Nova lorque, já descrito anteriormente. O objetivo da utilização deste método foi o de verificar os aspectos da percepção do usuário com análise qualitativa. Além disso, também foram marcados os obstáculos fixos e móveis presentes no passeio, avaliando se estavam adequados ou não à NBR 9050. Dessa maneira, permitiu-se ter uma noção básica da calçada e do contexto no qual está inserida. A aplicação deste método também auxiliou na percepção de quais elementos construídos podem influenciar no conforto e na segurança do pedestre. Para estas análises foram utilizadas as fichas propostas pelo Departamento de Planejamento de Nova lorque.

A seguir a primeira etapa do levantamento:
Tabela 8: Ficha resumo de aplicação dos critérios de análise nos trechos estudados - Freguesia do Ó, Trecho 1: Rua Dr. Estevão Montebelo. Fonte: Elaborado por Isabela Belini.

\section{FREGUESIA DO Ó}

Trecho 1: Rua Dr. Estevão Montebelo

(6)

(E)
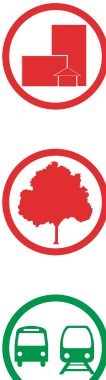

$\mathrm{km} / \mathrm{h}$

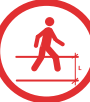

$\hat{\gamma}$

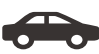

Ausência de infraestrutura ao ciclista

Não há estacionamentos privativos na área, porém os veículos podem estacionar nos dois lados da via

Há apenas um uso dos solos, que é residencial

Vegetação praticamente ausente na área

Apesar de estar longe do metrô, o trecho localiza-se a uma distância de até $150 \mathrm{~m}$ do ponto de ônibus

Limite da via é de $30 \mathrm{~km} / \mathrm{h}$

Mesmo com dimensões 1,95m e 1,05m, as calçadas apresentam passeio livre com menos de $60 \mathrm{~cm}$

12h15: 12 pedestres/hora

12h15: 85 veículos/hora 


\section{FREGUESIA DO Ó}

Trecho 2: Rua Mns. Januário Sangirardi

Ausência de infraestrutura ao ciclista
Não há estacionamentos privativos na área, porém os veículos
podem estacionar nos dois lados da via
Negetação praticamente ausente na área
Apesar de estar longe do metrô, o trecho abrange um ponto de
onibus
Limite da via é de 40km/h
Mesmo com alguns obstávulos, as calçadas, com dimensões 2,58m e
13h00: 120 pedestres/hora
13h00: 540 veículos/hora

Tabela 9: Ficha resumo de aplicação dos critérios de análise nos trechos estudados - Freguesia do Ó, Trecho 2: Rua Mns. Januário Sangirardi. Fonte: Elaborado por Isabela Belini. 


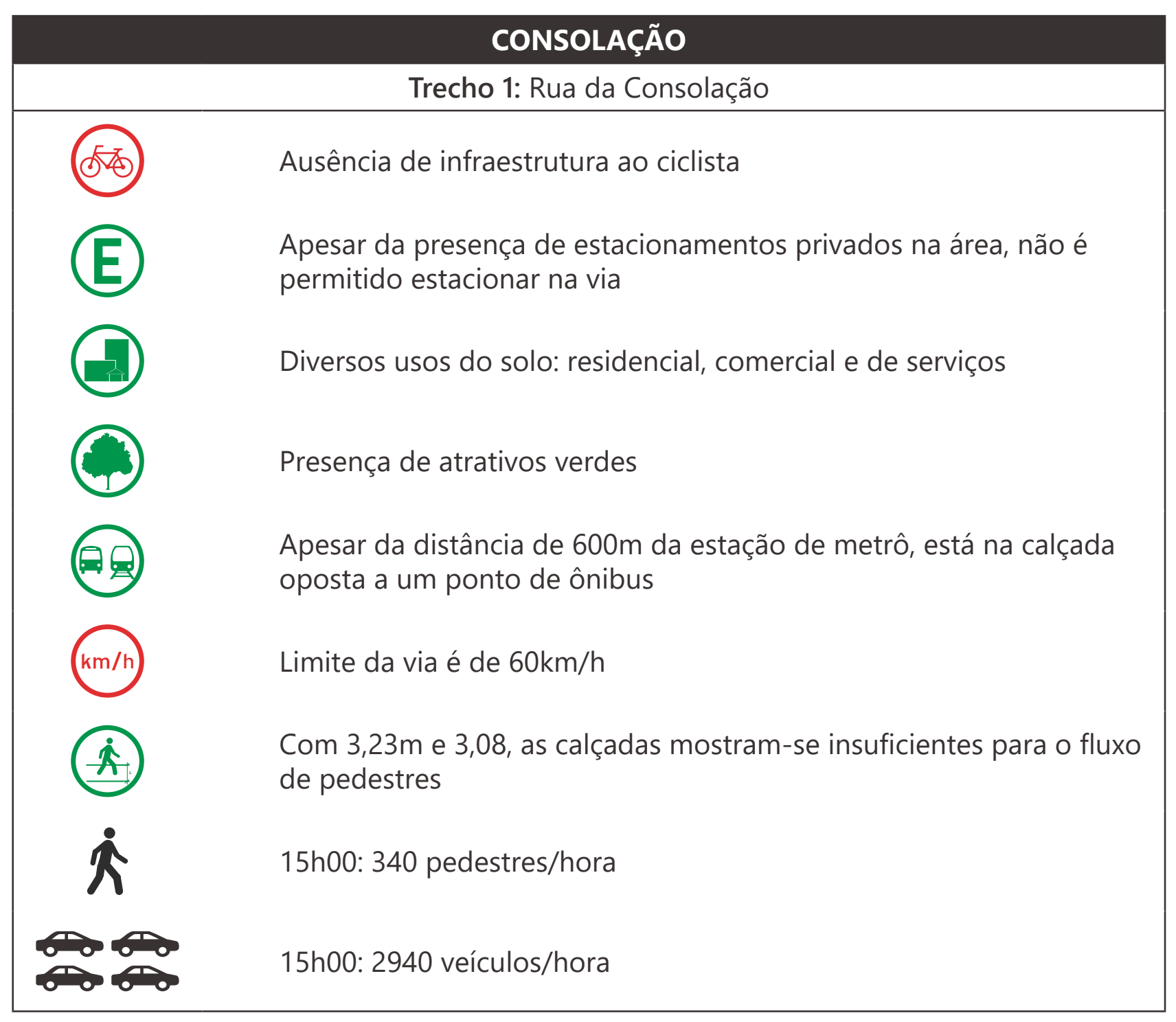

Tabela 10: Ficha resumo de aplicação dos critérios de análise nos trechos estudados - Consolação, Trecho 1: Rua da Consolação. Fonte: Elaborado por Isabela Belini. 


\section{CONSOLAÇÃO}

Trecho 2: Rua Da. Antônia de Queirós

(6) Ausência de infraestrutura ao ciclista

(E)

Não há estacionamentos privativos na área, e não é permitido estacionar na via de segunda a sábado, das $7 \mathrm{~h}$ às $22 \mathrm{~h}$

Diversos usos do solo: residencial, comercial e de serviço

Há presença de vegetação na área

Apesar da distância de $600 \mathrm{~m}$ da estação de metrô, está a menos de $150 \mathrm{~m}$ do ponto de ônibus

Limite da via é de $40 \mathrm{~km} / \mathrm{h}$

Com 3,65m de cada lado, as calçadas têm dimensão suficiente para o fluxo de pedestres

16h00: 520 pedestres/hora

16h00: 1140 veículos/hora

Tabela 11: Ficha resumo de aplicação dos critérios de análise nos trechos estudados - Consolação, Trecho 2: Rua Da. Antônia de Queirós. Fonte: Elaborado por Isabela Belini.
Além destes levantamentos, houve a aplicação do Método 4. Com o objetivo de verificar os aspectos da percepção do usuário com análise qualitativa.

Na segunda etapa, a partir da realização de cortes, elevações, plantas e perspectivas da rua a partir do olhar do pedestre (dividem o plano da calçada em quatro), houve a possibilidade de avaliação das possíveis sensações de quem anda pela calçada e os elementos que Ihe conferem aspectos positivos ou negativos, auxiliando em uma visão mais íntima do espaço (Figura 32). Completadas as fichas das visitas de campo, foi feita uma análise textual de cada trecho dos locais de estudo, levantando os principais pontos observados na visita e relacionando-os com as possíveis percepções dos pedestres nos lugares.

A seguir, alguns desenhos obtidos com a aplicação deste método: A partir do estudo da Freguesia do Ó, conclui-se que os ambientes externos à habitação pouco preocupam-se com o pedestre. Ruas 


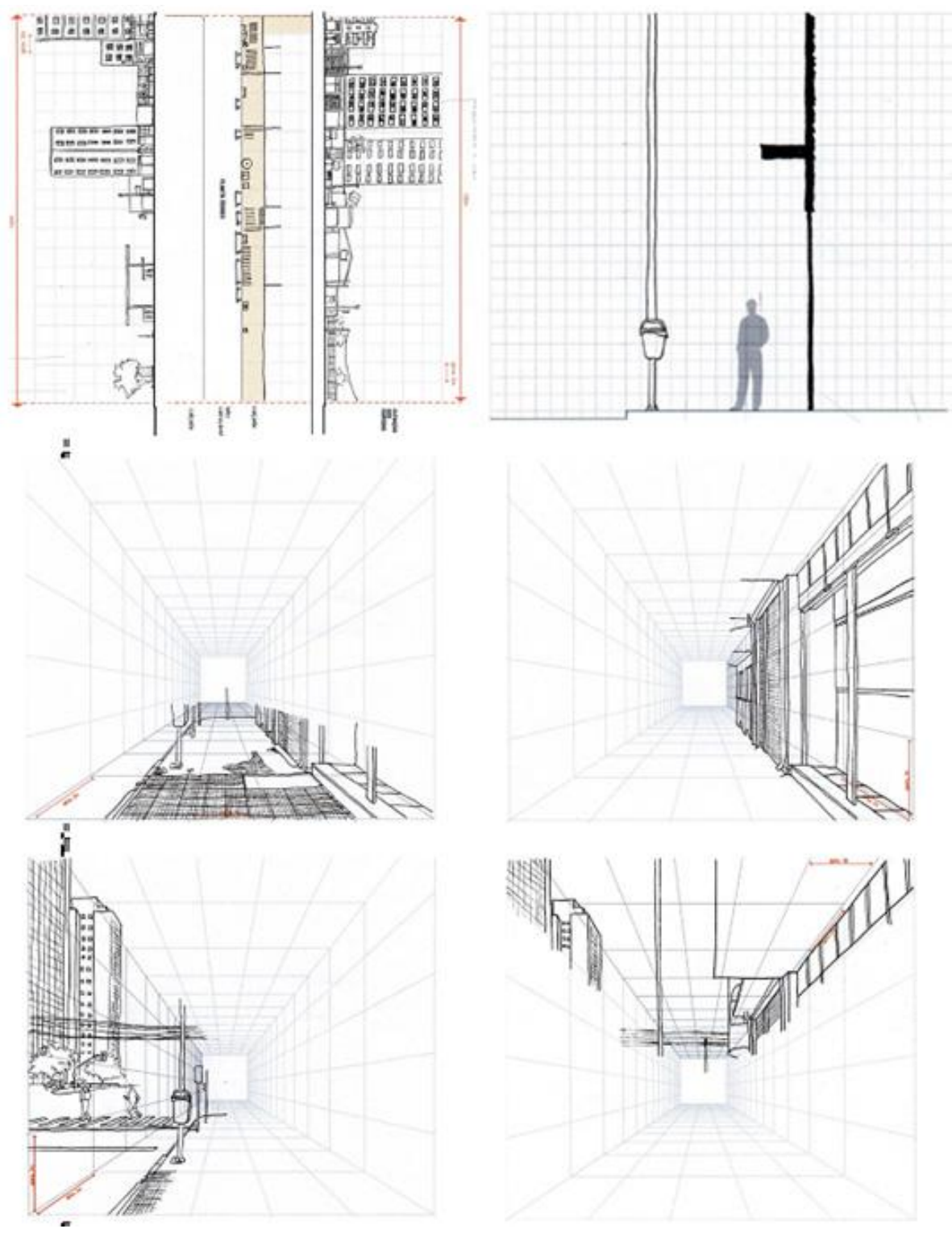

que apresentam escassa variedade de usos do solo, calçadas estreitas e com inúmeros obstáculos que frequentemente obrigam o pedestre a desviar seu caminho, edifícios sem recuo, inclinações em desacordo com a norma de acessibilidade, inexistência de atrativos verdes, sequências longas de gradis das casas, fios de postes de iluminação que prejudicam a visão do céu, grande quantidade de acessos às garagens e o consequente risco de atropelamento, entre muitas outras características, influenciam negativamente no espaço, gerando uma sensação de insegurança, e desmotivam as pessoas à percorrê-lo a pé.

Em relação à Consolação, embora com alguns defeitos, encontramse ambientes mais adequados. Apesar da alta velocidade e grande quantidade de veículos, a existência de diversos obstáculos na calçada e o ruído proveniente da rua são amenizados pela boa largura dos passeios, pela diversidade de usos do solo e da
Figura 32: Parte da análise qualitativa da Rua da Consolação. Fonte: Desenhos de Isabela Belini. 
composição dos edifícios (natureza, função, paleta de cores e gabaritos), existência considerável de atrativos verdes, pelo grande fluxo de pedestres, pela visibilidade contínua dos dois lados da rua e pela proximidade com meios de transporte público. Dessa maneira, garante-se a sensação de segurança de pedestres, a atratividade e funcionalidade do local.

Tendo em vista todas as análises que foram feitas por meios desses locais de estudo, como resultado da pesquisa, é possível verificar que os critérios estabelecidos auxiliam a avaliação das calçadas. Por outro lado, as combinações entre as ações que visam melhorar a qualidade das calçadas são infinitas.

Os pedestres não foram entrevistados neste trabalho. 


\section{Aplicação dos Métodos 1 e 4}

Avaliação de desempenho, sob o enfoque ergonômico, das funções e atividades da habitação com caráter social: os espaços internos e externos - Paraisópolis

\begin{abstract}
A favela configura espaços públicos muito diversos das tipologias urbanas presentes na cidade formal. Suas áreas livres, pouco planejadas, são constituídas por espaços residuais, que servem de acesso para as edificações. Entretanto, pode-se perceber uma diversidade muito grande nas atividades nelas realizadas. $O$ uso e a apropriação dos espaços públicos ocorrem com muito mais intensidade nas favelas do que na maioria dos demais bairros da cidade formal, apesar dos diversos problemas que podem ser observados em seus aspectos físicos.
\end{abstract}

Todas essas particularidades fazem com que não seja possível aplicar ao espaço da favela os mesmos métodos de levantamento ergonômico utilizados na cidade formal. Uma vez que as pessoas caminham pelo leito carroçável, não se pode estudar isoladamente as calçadas de lados opostos do leito carroçável, como é feito em outros casos. Foi necessário, assim, desenvolver um método que analisasse a rua como um todo.

As pesquisas de campo foram desenvolvidas em três frentes: a primeira delas referente ao desempenho ambiental do espaço urbano de Paraisópolis, a segunda aos aspectos ergonômicos no espaço público e a terceira à ergonomia no interior das habitações. Nesta tese será mostrada a segunda etapa, referente aos aspectos ergonômicos no espaço público ${ }^{14}$.

Foi determinado, também, um percurso para a realização de medições da qualidade ambiental, que inclui ruas e vielas, e se aproximam das habitações estudadas. Foi escolhido um trecho de uma rua e uma viela onde foram realizados os levantamentos de ergonomia. A seguir, será apresentado o método aplicado em cada uma dessas frentes.

Os primeiros levantamentos, referentes a primeira fase, realizados não estavam focados em requisitos ergonômicos, mas no desempenho ambiental de forma mais ampla. Foram coletados dados de umidade relativa e temperatura do ar com termo higrômetro, níveis de ruído com sonômetro, velocidade dos ventos com anemômetro, temperatura superficial com câmera termo visora e mascaramento do céu por meio de fotografias tiradas com lente olho de peixe.

Essas medições, necessárias para a realização da pesquisa, foram importantes também para as análises ergonômicas. Um ambiente
[14] Pesquisa associada a este levantamento: "A qualidade socioambiental dos espaços livres de favelas: estudo e proposição com referência na Cidade de São Paulo" (mestrado). Iniciação Científica / FAPESP-Cláudia Ferrara Carunchio - Avaliação de desempenho, sob o enfoque ergonômico, das funções e atividades da habitação com caráter social: os espaços internos e externos Paraisópolis. 
urbano considerado bom do ponto de vista ergonômico pode apresentar muitas deficiências no âmbito da qualidade ambiental, o que possivelmente muda a dinâmica de uso desse espaço. Ter uma visão geral do desempenho ambiental do espaço estudado se torna fundamental para entender o uso desses espaços e, assim, possibilitar o desenvolvimento de análises no âmbito da ergonomia.

Os locais onde seriam realizadas as medições dos aspectos mencionados acima foram determinados a partir do percurso estabelecido - antes do levantamento em campo, escolheramse alguns pontos desse percurso onde poderiam ser realizadas as medições. Em campo, verificou-se quais desses locais seriam mais interessantes para as medições, considerando quais pontos eram mais representativos da situação do ambiente da favela em geral e, ainda, elencando pontos que tivessem diferenças entre si, para que os levantamentos abarcassem as diversas tipologias de espaços presentes em Paraisópolis

Assim, foram escolhidos oito pontos distintos - um deles localizado fora da favela, na Av. Giovanni Gronchi, quatro em ruas de Paraisópolis e três em vielas. Isso possibilitou comparar as diferenças na qualidade ambiental da favela em relação ao tecido urbano da cidade formal, além das diferenças entre as ruas e as vielas. Em alguns locais foram realizadas duas medições no mesmo ponto - uma no sol e outra na sombra, permitindo avaliar as mudanças que seriam proporcionadas caso o espaço público contasse com mais dispositivos de proteção solar ou vegetação que proporcionasse sombra.

Figuras 33 e 34: Imagens das medições em campo. Fonte: arquivo de Naima Manfre.
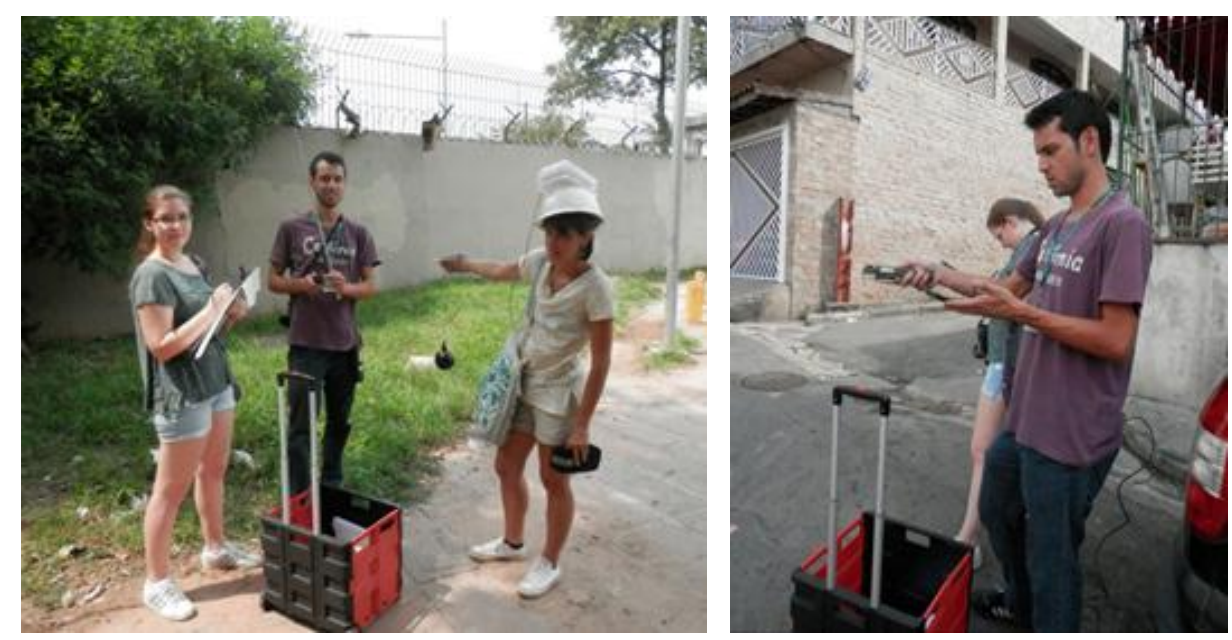

Para o desenvolvimento das análises ergonômicas das áreas externas, foram avaliados dois espaços urbanos: um trecho de 200 metros da Rua Melchior Giola, delimitado pelas ruas Pasquale Gallupi e Ernest Renan, e uma viela, que conecta a R. Melchior Giola à R. Herbert Spencer. Esses trechos foram demarcados no mapa a seguir, que também apresenta a localização das duas residências avaliadas internamente. 


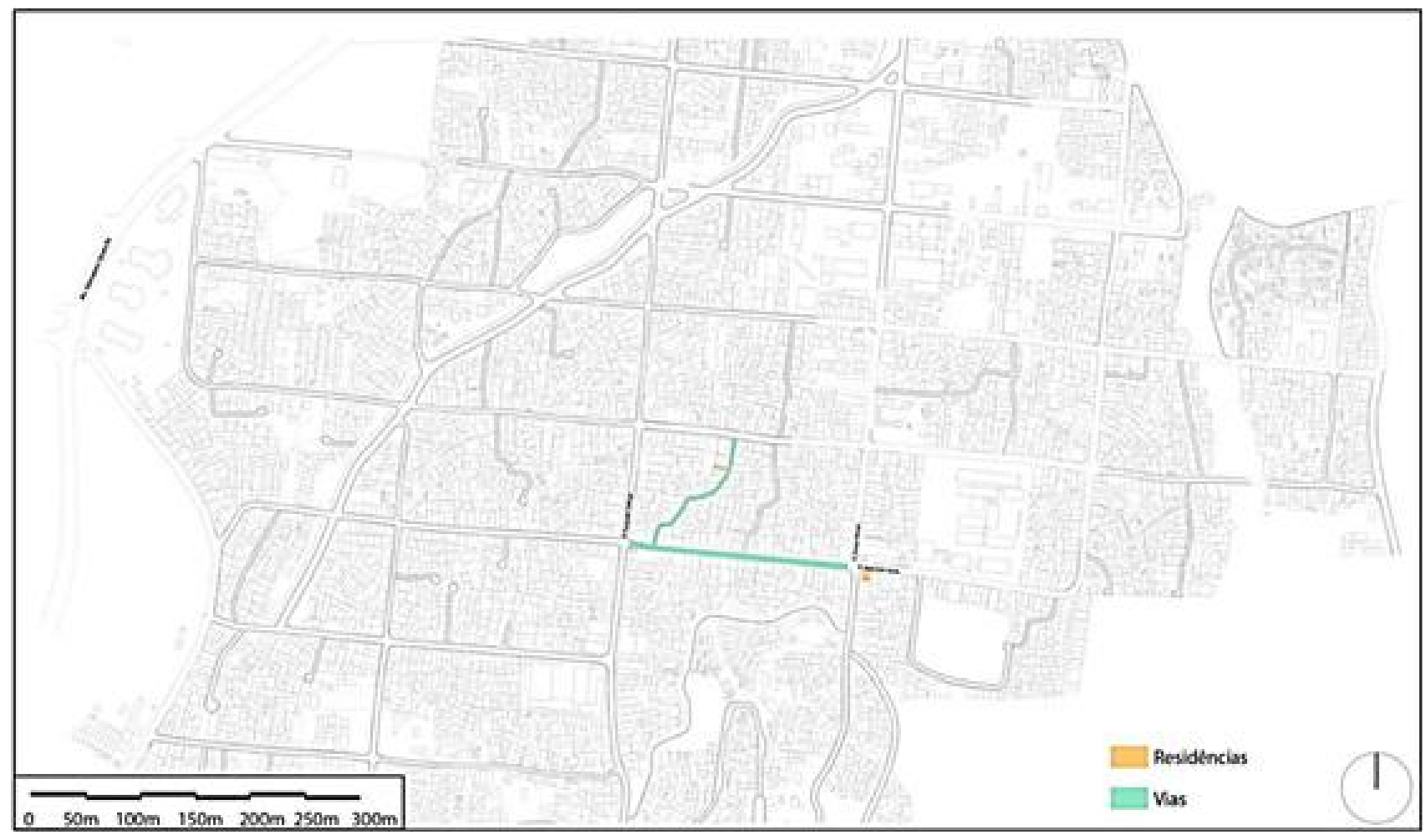

\section{O método para Paraisópolis}

O método desenvolvido para esta pesquisa apresenta alguns pontos em comum com o proposto em Nova lorque. Ambos tratam dos aspectos quantitativos e qualitativos do espaço, avaliados por meio de fichas específicas. É necessário destacar que, para as análises ergonômicas, não podem ser considerados apenas aspectos técnicos e dimensionais. Assim, ao se desenvolver o método para as áreas externas aplicado nesta pesquisa, buscou-se manter um aspecto muito positivo do método norte-americano - representar a sensação dos usuários nesses espaços. Para tanto, uma vez que seria inviável o uso desenhos elaborados em campo, como já discutido, propôs-se o uso de registros fotográficos para captar a relação entre os diversos elementos que compõem e integram o espaço das ruas e das vielas - as construções, suas fachadas, as calçadas com todos os obstáculos nelas presentes, os veículos parados e em trânsito e, obviamente, os pedestres.

Para os demais levantamentos, foram desenvolvidos três tipos de fichas, apresentadas na sequência. A primeira delas constitui uma base para mapear os obstáculos presentes nas calçadas e nas vielas. Para o desenvolvimento desta ficha, foi necessário primeiramente elencar os obstáculos comuns no ambiente urbano da favela. Foram considerados os obstáculos fixos e os móveis, selecionando, para esse último caso, os que estão presentes no espaço diariamente, como expositores de lojas colocados sobre as calçadas. Para cada tipo de obstáculo, foi elaborado um símbolo, que em conjunto constituem uma legenda, apresentada a seguir:
Figura 35: Mapa Paraisópolis com o trecho (rua e viela) e as casas selecionados. Fonte: Elaborado por Cláudia Carunchio. 
Figura 36: Legenda da localização dos obstáculos: levantamentos. Fonte: Elaborado por Cláudia Carunchio.
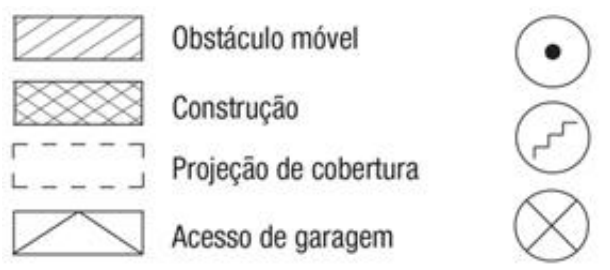

Árvore

Degrau

Depressão no piso
(O) Ponto de ônibus

(P) Poste

(PI) Placa

Essa legenda utilizada para apontar a localização dos obstáculos em planta. Diferentemente do método aplicado pelo Departamento de Planejamento de Nova lorque, a base para a elaboração dessas plantas não é um desenho de quadra genérico, mas um mapa do local onde será feito o mapeamento. Assim, facilita-se a localização dos obstáculos na planta, uma vez que o desenho da via e as próprias construções constituem uma referência para o mapeamento, tornando o processo mais rápido. Além disso, o uso do mapa é necessário, haja vista que não há como desenvolver um desenho genérico para as vielas de uma favela.

O mesmo mapa está presente na segunda ficha, que é uma base para as medições das larguras da viela em diversos pontos. Como as vielas são espaços residuais, seus limites não foram pré-estabelecidos, mas sim definidos pelas próprias construções. Assim, de acordo com o tamanho e a forma das edificações, a viela configura-se com uma forma irregular - em alguns trechos mais estreita, em outros mais larga. Em vista disso, torna-se necessário medir sua largura em diversos trechos, já que não se pode assumir um deles como característico daquela viela. A segunda ficha é, portanto, uma base para demarcar os locais em que a largura foi medida, com campos para anotar os respectivos valores.

A terceira ficha tem a função de auxiliar a avaliação de aspectos qualitativos do espaço. Em campo, são preenchidas duas dessas fichas - uma para a rua e outra para a viela. Os parâmetros que devem ser avaliados em campo foram elencados em uma tabela, que deve ser preenchida em campo assinalando-se uma de três opções: a primeira se o parâmetro em questão existe/é atendido de maneira adequada, a segunda se existe parcialmente/é atendido de maneira inadequada, e a terceira se não existe/não é atendido.

Nessa mesma ficha, há uma tabela de apoio para a quantificação dos fluxos. Tanto na rua como na viela analisada, deve ser realizada uma filmagem que capte a via transversalmente durante 4 minutos, para que posteriormente seja contado o fluxo de pedestres, automóveis, motocicletas, bicicletas, ônibus e caminhões. Com base no valor obtido, podem ser estimados os fluxos por hora.

Após o preenchimento dessas fichas em campo, inicia-se a fase de tabulação e análise dos resultados, permitindo o entendimento dos problemas no âmbito da ergonomia e dos potenciais desse 
espaço e, então, a constituição de um embasamento para projetos que considerem os problemas e as necessidades reais da favela.

\section{Os levantamentos}

Antes mesmo de se iniciarem os levantamentos em campo, com o preenchimento das fichas desenvolvidas para integrar o método de pesquisa, algumas percepções iniciais permitiram identificar muitos problemas no âmbito da ergonomia, mas também grandes potenciais daquele ambiente urbano. $O$ primeiro fator a chamar atenção foi o uso intenso que a população faz do espaço público, não apenas para o ato de circular, mas também como local de encontro. Pôde-se notar, ainda, uma grande diversidade de estímulos - uma paisagem composta por inúmeros elementos (construções de tipologias e alturas diversas, veículos de diferentes portes transitando constantemente e estacionados próximos às calçadas, expositores de lojas com mercadorias nos passeios, além de inúmeros outros obstáculos nas calçadas), ruídos diversos, um uso do solo diversificado, atraindo diferentes públicos para os estabelecimentos comerciais, além de, evidentemente, muitas pessoas realizando atividades diversas e interagindo entre si.

Os levantamentos iniciaram-se de fato com o mapeamento dos obstáculos presentes nas calçadas ao longo do trecho avaliado da R. Melchior Giola. Ao longo desse processo, foram sendo realizados registros fotográficos. O mesmo foi realizado para a viela, resultando no mapeamento apresentado a seguir:

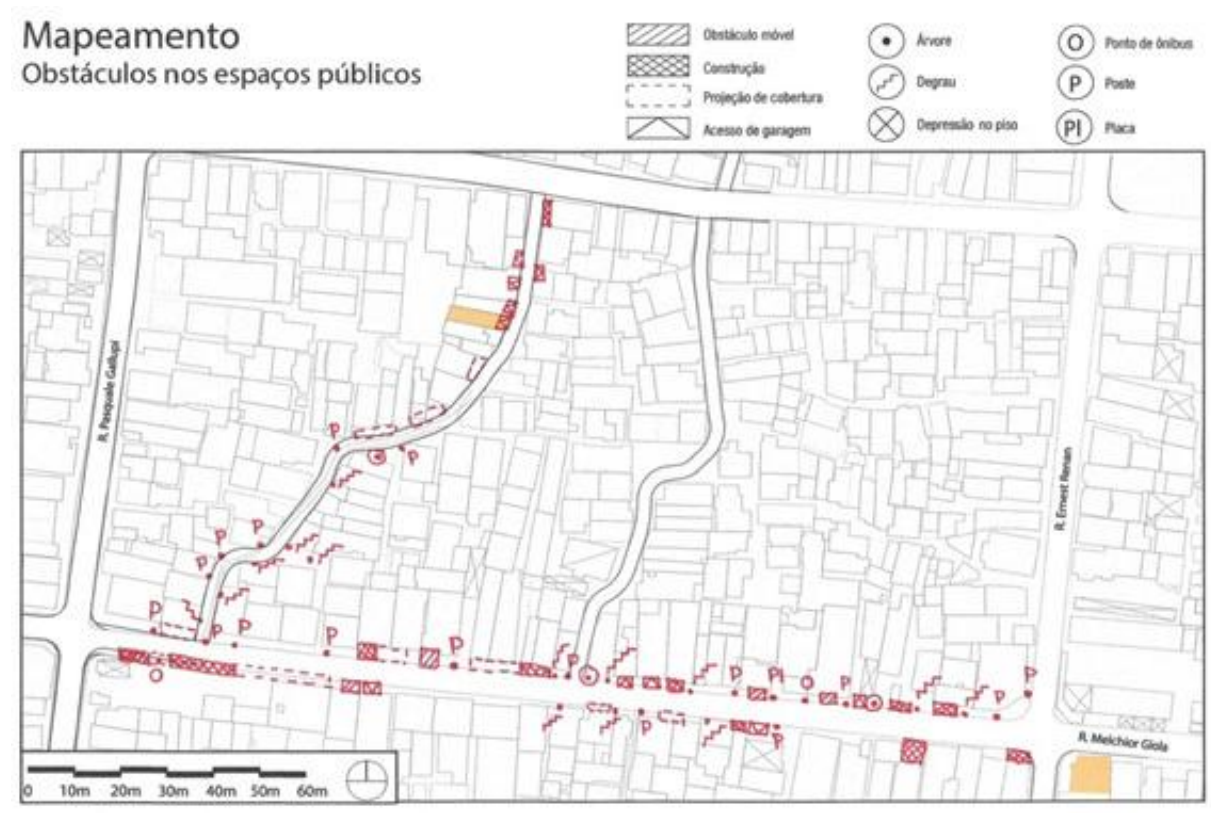

Figura 37: Levantamento Paraisópolis na rua - obstáculos. Fonte: Elaborado por Cláudia Carunchio. 
Esse mapeamento já permite identificar a imensa quantidade de obstáculos presentes nas calçadas, que em diversos pontos ficam totalmente obstruídas. No entanto, para se compreender a real situação do espaço da rua quanto à ergonomia, é necessário olhar também para os aspectos qualitativos e para os fluxos de pedestres e veículos, apresentados na ficha abaixo:

\section{ANÁLISE QUALITATIVA DOS ESPAÇOS PÚBLICOS - RUA}

\begin{tabular}{|l|c|c|c|}
\hline \multicolumn{1}{|c|}{ Pontos a serem observados } & $\checkmark$ & \pm & $\mathrm{X}$ \\
\hline Iluminação pública & $\mathrm{x}$ & & \\
\hline Atrativos verdes & & & $\mathrm{x}$ \\
\hline Uso do solo diversificado & $\mathrm{x}$ & & \\
\hline Transparência nas fachadas & $\mathrm{x}$ & & \\
\hline Fluxo de pedestres separado do de veículos & & & $\mathrm{x}$ \\
\hline Proteção contra sol e chuva & & & $\mathrm{x}$ \\
\hline Fachadas atrativas & $\mathrm{x}$ & & \\
\hline Espaços adequados para caminhar & & & $\mathrm{x}$ \\
\hline Espaços de permanência & & & $\mathrm{x}$ \\
\hline Espaço para recreação & & & $\mathrm{x}$ \\
\hline Espaço para a prática de atividades físicas & & & $\mathrm{x}$ \\
\hline Mobiliário Urbano & & & $\mathrm{x}$ \\
\hline Linhas de visão & & $\mathrm{x}$ & \\
\hline Baixos níveis de ruídos & & & $\mathrm{x}$ \\
\hline Piso regular & & & $\mathrm{x}$ \\
\hline Tipo de piso adequado & & $\mathrm{x}$ & \\
\hline Lixeiras & & & $\mathrm{x}$ \\
\hline Ausência de lixo no chão & & $\mathrm{x}$ \\
\hline
\end{tabular}

\begin{tabular}{|c|c|c|}
\hline Fluxos & Em 4min & Em 1h \\
\hline Pedestres & 98 & 1470 \\
\hline Automóveis & 8 & 120 \\
\hline Ônibus & 2 & 30 \\
\hline Caminhões & 3 & 45 \\
\hline Motocicletas & 7 & 105 \\
\hline Bicicletas & 0 & 0 \\
\hline \multicolumn{3}{|c|}{ OBSERVAÇÕES } \\
\hline \multicolumn{3}{|c|}{$\begin{array}{l}\text { - muitos trechos das calçadas } \\
\text { totalmente obstruídos por } \\
\text { obstáculos; }\end{array}$} \\
\hline \multicolumn{3}{|c|}{$\begin{array}{l}\text { - grande desnível entre a calçada } \\
\text { e a rua em alguns trechos; } \\
\text { - muitos carros estacionados; }\end{array}$} \\
\hline \multicolumn{3}{|c|}{$\begin{array}{l}\text { - fios de eletricidade em excesso } \\
\text { e desordenados. }\end{array}$} \\
\hline
\end{tabular}

Tabela 12: Análise Paraisópolis com o trecho (rua e viela). Fonte: Elaborado por Cláudia Carunchio.
O levantamento de fluxos permite identificar que existem muito mais pedestres do que veículos circulando pela rua. Apesar disso, pode-se notar claramente uma priorização do tráfego de veículos, como ocorre na maior parte da cidade de São Paulo. Uma vez que existem muitos obstáculos nas calçadas, que fazem com que em alguns trechos elas estejam completamente obstruídas, os pedestres são obrigados a circular pelo leito carroçável, correndo grande risco de atropelamento. Essa grande quantidade de obstáculos também cria uma barreira visual - embora a malha viária seja reticulada e ortogonal, não é possível avistar um extenso trecho da rua, uma vez que existem nas calçadas diversos elementos que se sobrepõe e no leito carroçável muitos veículos em trânsito e estacionados.

A situação dos pedestres ao terem que se locomover pelo leito carroçável é agravada pelo fato de existirem carros estacionados em quase toda a extensão da via, pois isso impossibilita que os transeuntes circulem pelas calçadas e utilizem o leito carroçável 
apenas nos trechos em que os passeios estão completamente obstruídos, ou que andem pelo leito carroçável, mais próximos à calçada. Assim, os pedestres são forçados a circularem entre os carros estacionados e os que estão em trânsito, aumentando ainda mais os riscos.

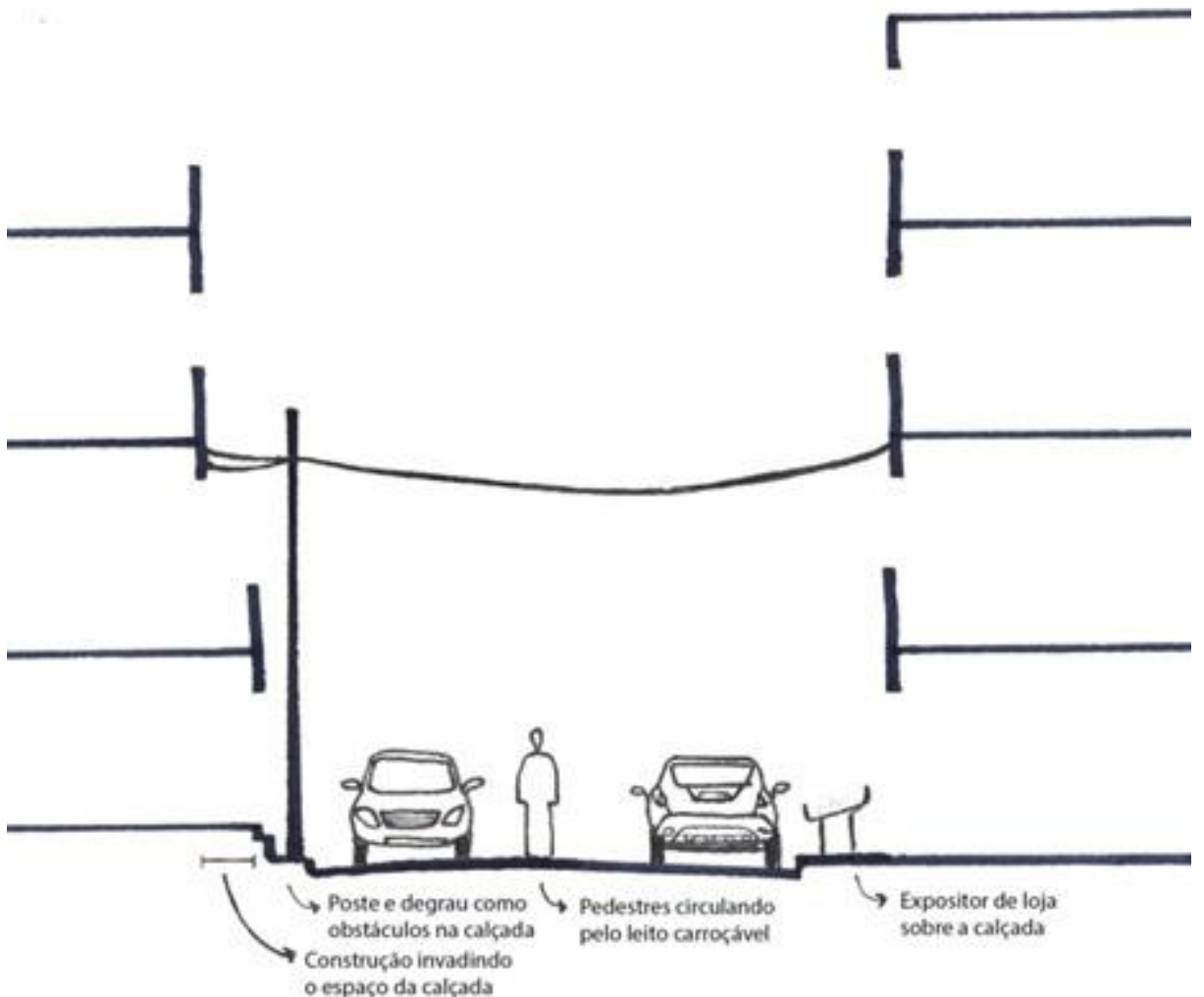

Figura 38: Corte esquemático das ruas de Paraisópolis, com representação dos obstáculos presentes nas calçadas e da área utilizada para a circulação pelos pedestres. Fonte: Elaborado por Cláudia Carunchio.

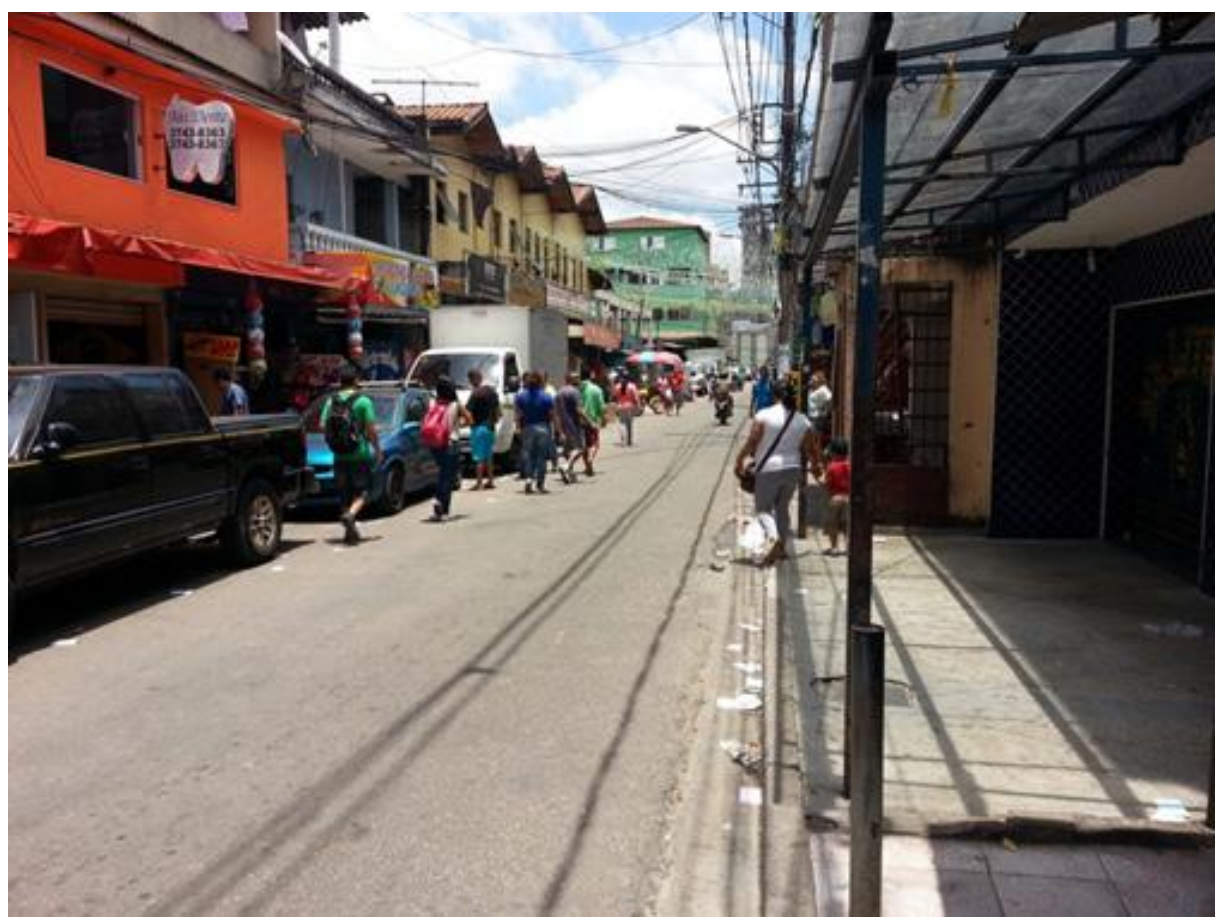

Figura 39: Pedestres circulando pelo leito carroçável.Fonte: Foto de Cláudia Carunchio. 
Figura 40: Poluição visual causada pelos fios de eletricidade / Pessoas caminhando junto aos carros "ausência" de calçadas. Fonte: Foto de Cláudia Carunchio.
As calçadas de Paraisópolis apresentam largura insuficiente e uma grande quantidade de obstáculos, o que faz com que não sejam espaços adequados para a circulação. Além de postes, placas e outros obstáculos, que não prejudicariam a circulação caso os passeios apresentassem dimensões grandes o suficiente, existem diversas irregularidades e degraus, que dificultam a atividade de andar, principalmente para pessoas com mobilidade reduzida. É comum, também, esse espaço ser encarado como uma possibilidade para a extensão dos imóveis, havendo construções que avançam sobre as calçadas, e estabelecimentos comerciais que colocam nelas parte de suas mercadorias durante o horário de funcionamento. Os diversos problemas ergonômicos fazem com que as calçadas sejam inadequadas para a circulação, forçando pedestres e veículos a dividirem o mesmo espaço, o que gera desconforto e riscos aos usuários.

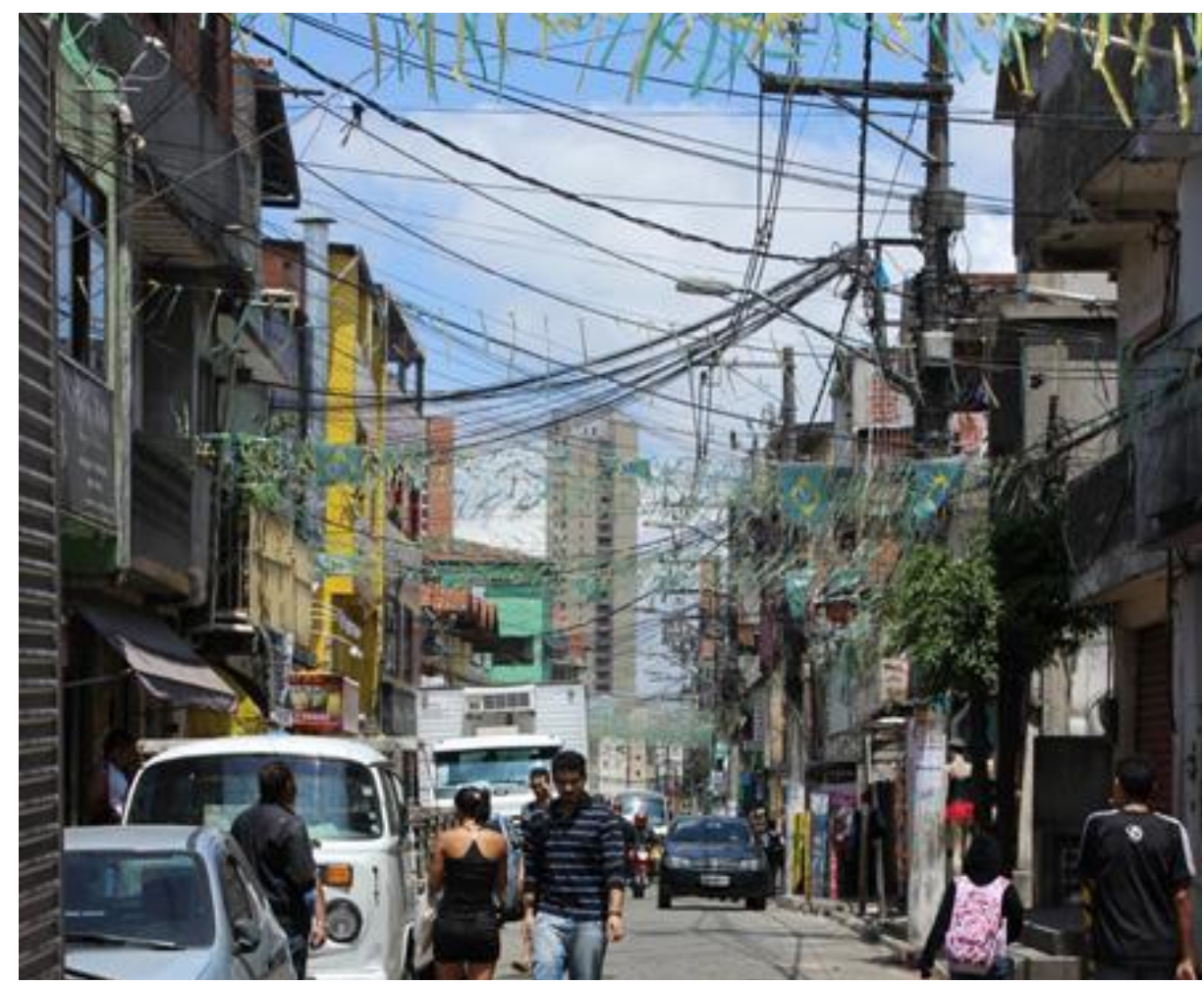

Embora essa situação seja problemática para todos os usuários, determinados grupos os riscos são ainda maiores, como para crianças, idosos e deficientes físicos. Esses usuários apresentam mais dificuldade de contornar os obstáculos presentes no passeio e de circular entre os veículos, o que resulta em maiores riscos de queda e de atropelamento. Deve-se considerar que, juntos, esses grupos constituem uma parte significativa dos pedestres que circulam pela via avaliada. Nos quatro minutos nos quais os fluxos foram contados, passaram pela via 98 pedestres; entre esses, 32, ou seja, cerca de um terço dos transeuntes, pertenciam a algum desses grupos de maior risco, como pode ser visto na tabela ao lado: 


\begin{tabular}{|l|c|}
\hline \multicolumn{1}{|c|}{ GRUPO AVALIAD0 } & EM 4 MINUTOS \\
\hline Número total de pessoas & 98 \\
\hline Pessoas com crianças de colo & 7 \\
\hline Crianças acompanhadas por adultos & 6 \\
\hline Crianças desacompanhadas & 16 \\
\hline Idosos & 3 \\
\hline Deficientes físicos & 0 \\
\hline
\end{tabular}

Tendo em vista esse panorama, é evidente a necessidade de intervenções nos espaços públicos que visem adequá-los, para que os pedestres possam utilizá-los de forma segura. Para tanto, é essencial criar espaços apropriados para a circulação, livres de obstáculos e nos quais o fluxo de pedestres esteja segregado do de veículos. Assim, deve-se garantir a existência de uma faixa livre em toda a extensão das calçadas, com largura suficiente para comportar o fluxo medido.

No trecho da rua avaliado, a largura das calçadas apresenta grandes variações, sendo maior ou menor de acordo com a área ocupada por cada construção, assim como ocorre nas demais vias da favela. Em média, as calçadas apresentam um metro de largura, sendo maiores em alguns trechos e menores em outros, havendo pontos em que não existem calçadas, uma vez que algumas construções avançam até o meio-fio. Essa largura, no entanto, não corresponde à dimensão da faixa livre, mas à largura total do passeio. Assim, sobre essa pequena dimensão de um metro, ainda existem inúmeros obstáculos, como postes, degraus e até mesmo escadas.

A largura que a faixa livre deveria apresentar pode ser dimensionada de acordo com a NBR 9050, Acessibilidade a edificações, mobiliário, equipamentos urbanos, conforme apresentado no tópico - $\mathrm{O}$ espaço da calçada e o andar como trabalho, por meio da equação:

$$
L=F / K+\Sigma i \leq 1,2 m
$$

Na qual:

L é a largura da faixa livre;

F é o fluxo de pedestres estimado ou medido nos horários de pico (pedestres por minuto por metro);

$\mathrm{K}=25$ pedestres por minuto;

$\Sigma$ i é o somatório dos valores adicionais relativos aos fatores de impedância, que são:

0,45 m junto a vitrines ou comércio no alinhamento;

0,25 m junto a mobiliário urbano;

$0,25 \mathrm{~m}$ junto à entrada de edificações no alinhamento.
Tabela 13: Fluxo de pedestres. Fonte: Elaborado por Cláudia Carunchio. 
Considerando que nos quatro minutos de contagem de fluxo passaram pela rua avaliada 98 pedestres, pode-se estimar que o fluxo nessa via é de 24,5 pedestres por minuto. Caso esse fluxo se dividisse igualmente pelos passeios existentes nos dois lados da via, o fluxo em cada calçada seria de 12,25 pedestres por minuto. Assim, nos trechos em que existe mobiliário público e vitrines ou comércio no alinhamento da calçada, componentes que resultam no maior valor do fator de impedância, a largura da faixa livre deveria ser:

$$
\begin{gathered}
L=12,25 / 25+0,45+0,25 \leq 1,2 \mathrm{~m} \\
L=0,49+0,7 \leq 1,2 \mathrm{~m} \\
L=1,19 \leq 1,2 \mathrm{~m}
\end{gathered}
$$

Como o valor calculado foi inferior à largura mínima estipulada pela norma, de 1,2 m, esse valor deveria ser adotado, mesmo nos trechos em que não existem aqueles fatores de impedância. Para que seja estabelecida uma faixa livre com essas dimensões, seria necessário aumentar muito a largura das calçadas, o que pode ser problemático em alguns casos. Uma forma de contornar esse problema é por meio da redução da quantidade de obstáculos nos passeios, para o estabelecimento de mais área livre para a circulação. Os postes, por exemplo, poderiam ser suprimidos caso a fiação elétrica fosse enterrada. Além de contribuir para a mobilidade dos pedestres, essa medida reduziria a necessidade de manutenção da rede elétrica, uma vez que a fiação ficaria mais protegida contra eventuais danos, e diminuiria a poluição visual, que atualmente é intensificada pela grande quantidade de fios.

Apesar de os maiores problemas das calçadas no âmbito da ergonomia estarem relacionados à grande quantidade de obstáculos e à largura insuficiente, existem, ainda, outros fatores que dificultam sua utilização. Embora o piso seja de concreto na maior parte da extensão das calçadas, material considerado ideal para esse espaço, existem alguns trechos que apresentam outros tipos de piso, como cerâmicas, que podem dificultar a locomoção e representar risco em determinadas condições, como quando estão molhados. Além disso, o piso de concreto não é regular, apresentando diversas fissuras e pequenos buracos, que aumentam os riscos de queda. Outro problema se refere à diferença de nível entre as calçadas e o leito carroçável, que embora seja adequada em alguns trechos, em outros é excessivamente grande, havendo pontos em que o desnível é de cerca de $25 \mathrm{~cm}$.

A falta de atrativos verdes é outra deficiência do espaço público 
de Paraisópolis, que se manifesta tanto nas ruas como nas vielas. Quase não há árvores e a pouca vegetação existente é de pequeno porte, plantada pelos próprios moradores em locais muitas vezes improvisados, como forma de contornar essa carência. A presença de mais árvores não beneficiaria apenas a qualidade ambiental desses espaços, mas também os pedestres, que poderiam se locomover por uma área mais sombreada e mais agradável.

Ainda que existam grandes problemas, as ruas de Paraisópolis apresentam também aspectos positivos quanto à ergonomia, que poderiam ser potencializados caso as calçadas fossem adequadas para a circulação de pedestres. A existência de habitações mescladas com comércios e serviços de inúmeros tipos resulta em um uso do solo diversificado, que apresenta a vantagem de atrair usuários com diversos perfis e de estimular a locomoção a pé, intensificando o uso dos espaços públicos e, assim, fazendo com que esses sejam mais seguros.

Outro fator que contribui para intensificar o uso dos espaços públicos é a existência de fachadas atrativas, como vitrines de lojas, que torna os percursos percorridos a pé mais interessantes, estimulando essa prática. No entanto, uma vez que os pedestres não podem caminhar pelas calçadas, essa relação com o que existe no térreo das edificações é em parte perdida. Dessa forma, a existência de calçadas adequadas não apenas tornaria o ato de se deslocar a pé mais seguro, mas também mais agradável, uma vez que os percursos se tornam mais interessantes e menos cansativos de serem percorridos.

Existe, ainda, uma demanda por espaços públicos de permanência. Os poucos trechos em que as calçadas são mais largas costumam ser utilizados como áreas de convivência por moradores que eventualmente se encontram ou por pessoas que querem passar algum tempo nas áreas livres, haja vista que não existem espaços adequados para isso. Como também falta mobiliário urbano, a população cria alternativas improvisadas, como utilizar degraus e desníveis como bancos.

Considerando todos os problemas apontados e suas implicações, elaboraram-se algumas diretrizes, que não dizem respeito apenas a esse trecho, mas que podem ser aplicadas às ruas de forma geral. Por meio delas, pretende-se atender às demandas existentes, criando espaços que possam ser utilizados pela população de forma intensa e segura, e aproveitando os potenciais do ambiente urbano da favela.

Primeiramente, propõe-se a retirada de todos os obstáculos que possam ser eliminados das calçadas. Em alguns locais, ocorreu uma apropriação do espaço público pelos proprietários dos imóveis, 
que utilizaram o espaço do passeio para colocar escadas que dão acesso aos pavimentos superiores das edificações. Nesses casos, remover esses obstáculos das calçadas seria muito complicado, pois envolveria, obrigatoriamente, grandes reformas nas edificações, para mudar seus acessos. No entanto, existem obstáculos que podem ser removidos de forma mais simples, como os postes, que podem ser suprimidos caso a fiação elétrica seja enterrada, como já mencionado anteriormente. Assim, aumenta-se o espaço disponível para circulação nas calçadas. Caso isso fosse feito, seria necessário inserir postes de iluminação, que, no entanto, não ocupam tanto espaço quanto os que sustentam os fios elétricos; além disso, poder-se-ia pensar a localização desses postes de iluminação considerando os trechos nos quais os passeios são mais largos, para que não prejudicassem a circulação.

Apenas a remoção de alguns obstáculos não é, contudo, suficiente para estabelecer uma faixa livre para a circulação com 1,2 m de largura, dimensão determinada pela NBR 9050. Para que isso seja possível, propõe-se um aumento de cerca de $80 \mathrm{~cm}$ na largura das calçadas, que somado às áreas já existentes nos passeios e às novas áreas que seriam liberadas com a remoção de obstáculos, configuraria um espaço adequado para os pedestres circularem de forma segura. Esse aumento de $80 \mathrm{~cm}$ em cada uma das calçadas diminuiria a largura do leito carroçável, que, todavia, poderia continuar apresentando uma faixa de rolamento e uma área livre para o estacionamento e veículos e a descarga dos pequenos caminhões que abastecem o comércio. Embora em alguns trechos específicos, como nos que as construções se aproximam do meio-fio, esse aumento não seria suficiente para que a faixa livre apresentasse 1,2 $\mathrm{m}$ de largura, isso seria conseguido em grande parte do passeio, e garantir-se-ia que em toda a extensão da via existisse a possibilidade de os pedestres circularem em uma área segregada do tráfego de veículos, de forma segura.

Para melhorar as condições de mobilidade, propõe-se também a remoção das irregularidades do piso das calçadas e a troca da pavimentação por concreto nas áreas em que o piso é feito de outros materiais. Propõe-se, ainda, o estabelecimento de rampas nas esquinas para facilitar a travessia de ruas, principalmente para deficientes físicos e pessoas empurrando objetos como carrinhos de bebês.

Uma alternativa para a falta de espaços de permanência poderia ser a criação de áreas anexas às calçadas, que ocupem parte do espaço destinado ao estacionamento de veículos no leito carroçável, como "parklets". Nessas áreas, poderia ser colocado mobiliário urbano, como bancos e lixeiras, estabelecendo espaços de convivência adequados, sem prejudicar a circulação de 
pedestres. Essas pequenas áreas também poderiam ser utilizadas para a colocação de arbustos e pequenas árvores, contribuído para a qualidade ambiental dos espaços públicos e sombreando parte do espaço da calçada, tornando os deslocamentos a pé mais agradáveis.
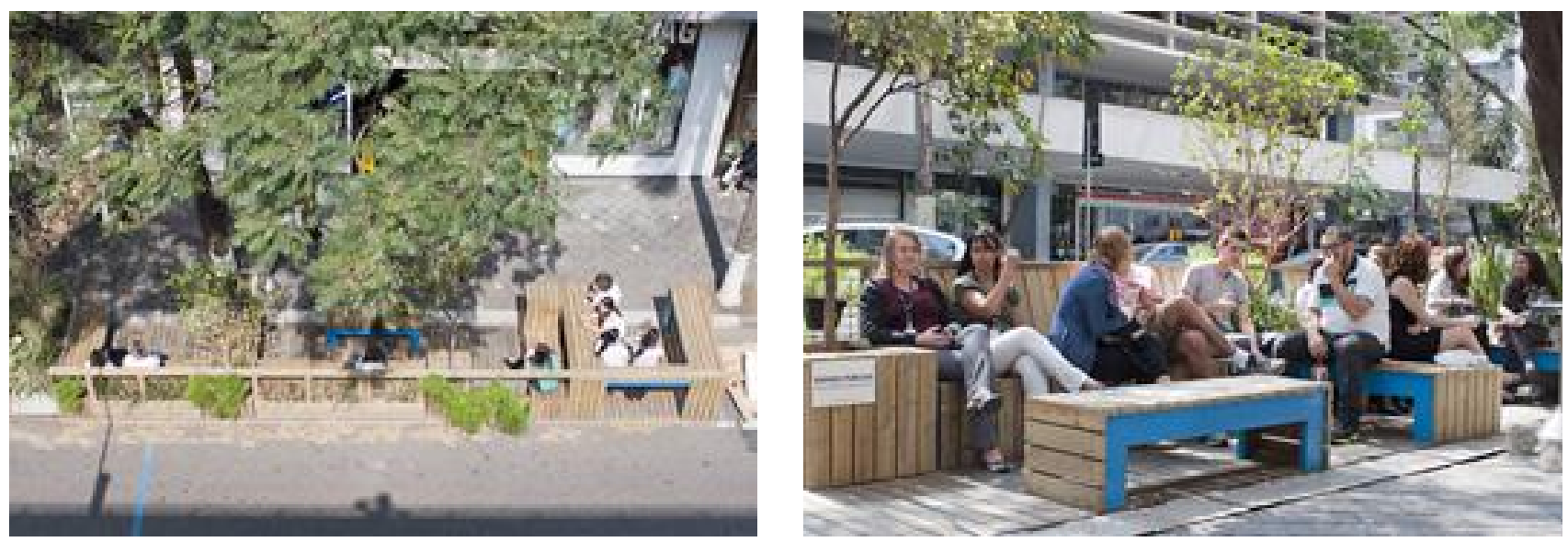

As imagens a seguir buscam ilustrar de forma esquemática as propostas aqui apresentadas para o espaço das ruas, demonstrando as vantagens que essa configuração traria para os usuários desse ambiente.
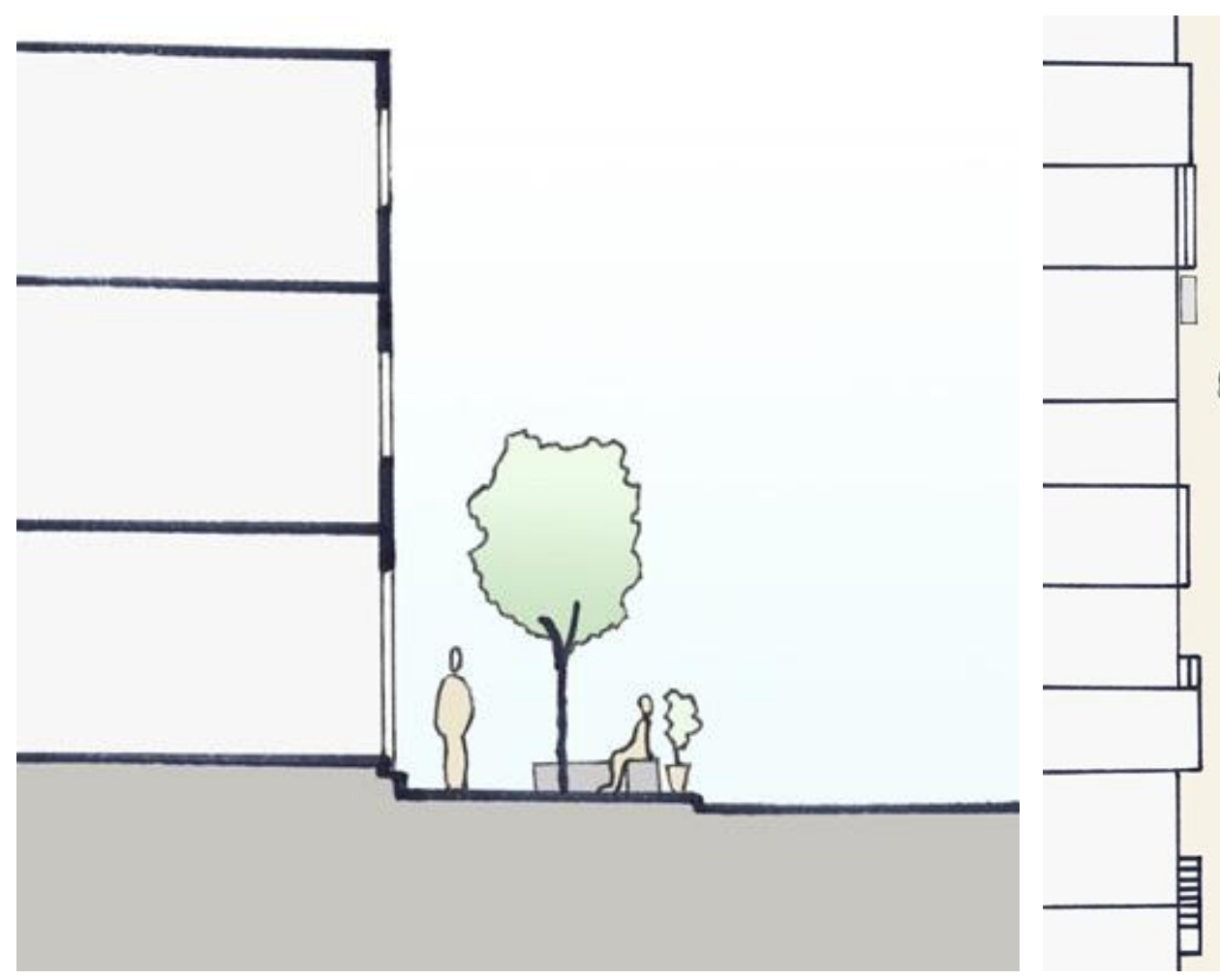

As propostas mencionadas anteriormente auxiliam na constituição de um espaço público com menos problemas de ergonomia e mais adequados para as necessidades dos usuários. No entanto, para que isso ocorra de forma completa, é essencial olhar também para o espaço das vielas. As vielas apresentam, no geral, mais
Figuras 41 e 42: Parklets em São Paulo. Fonte: http://www1.folha.uol. com.br/saopaulo/2014/09/1518236conheca-os-parklets-minipracasinstaladas-em-vagas-de-carros. shtml. 
Figura 45: Levantamento Paraisópolis na viela - largura. Fonte: Elaborado por Cláudia Carunchio. problemas de ergonomia do que as ruas, uma vez que são espaços residuais, mantidos livres para possibilitar o acesso às construções localizadas no interior da quadra. Assim, diferentemente da rua, não houve um planejamento desses espaços, que, em alguns casos, são apenas suficientes para permitir a passagem de uma pessoa.

Existem, ainda, as vielas, que apresentam pequenas dimensões, às vezes insuficientes para a passagem simultânea de duas pessoas lado a lado. No entanto, nas vielas relativamente maiores, circulam, além de pedestres, bicicletas e motocicletas. Esses espaços, incomuns na cidade formal, são pouco qualificados e destinados principalmente à circulação, tanto para acessar edificações como para reduzir distâncias.

Como o traçado das vielas é determinado pelas edificações que a circundam, suas larguras apresentam grandes variações a cada trecho. Portanto, para a realização de uma avaliação ergonômica, foi necessário medir as larguras desses espaços em diversos pontos, o que permite caracterizar a viela de forma adequada, considerando suas diferenças tipológicas. Na ficha abaixo, estão demarcados os pontos de medição na viela avaliada e suas respectivas larguras.

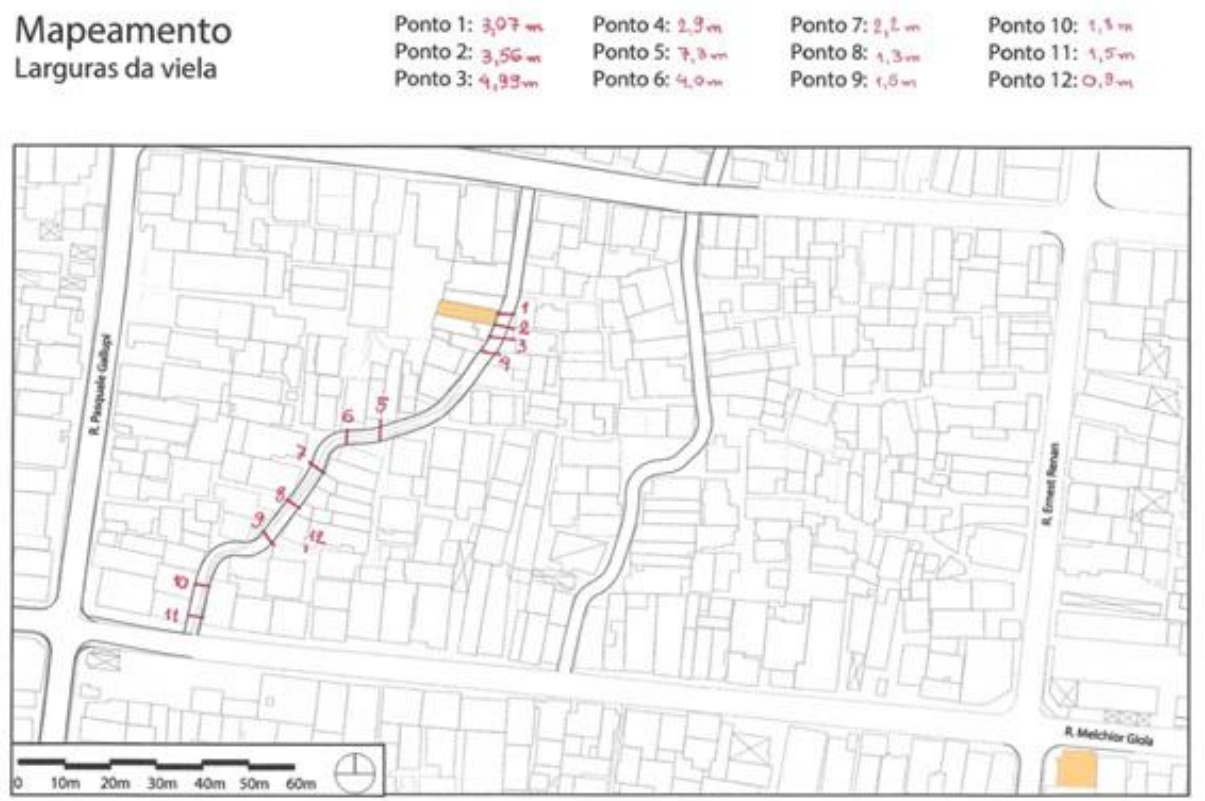

Pode-se perceber que essa viela apresenta uma grande variação entre a largura das áreas próximas à R. Melchior Giola e a da extremidade oposta, que a conecta à R. Herbert Spencer. Nessas áreas mais largas existem, inclusive, residências com garagem para automóvel, como pode ser visto no mapeamento de obstáculos, apresentado no início desse capítulo. Esse é o caso da moradia visitada e analisada, demarcada no mapa em laranja. Existem trechos, como o ponto 5, nos quais a largura é muito superior 
a das demais partes da viela. Isso ocorre devido às reentrâncias existentes entre as construções, que configuram espaços residuais não utilizados para circulação. Esses espaços poderiam ser utilizados para a colocação de algum mobiliário urbano ou de vegetação de pequeno porte, quase inexistente nas vielas.

É necessário salientar que a maior parte das vielas é mais estreita do que essa que foi avaliada, apresentando, assim, mais problemas no âmbito da ergonomia. A escolha dessa viela se deu devido à localização de uma das residências visitadas para a análise do espaço interno das habitações e de uma das residências na qual Eduardo Pizarro realizou as medições de desempenho ambiental, uma vez que ambas estão voltadas para a viela em questão.

Embora existam inúmeros obstáculos nas vielas, como degraus, escadas e postes, os maiores problemas de ergonomia decorrem da pequena largura das passagens. Isso faz com as intervenções nas vielas sejam mais complicadas do que nas ruas, pois não é possível aumentar suas dimensões sem comprometer o espaço das edificações. Em vista disso, é importante que as ações nas vielas busquem reduzir a área ocupada por obstáculos, para que se otimize o aproveitamento do pouco espaço disponível.

No mapeamento de obstáculos, é possível perceber a existência de diversos postes ao longo da viela. Esses postes são diferentes dos encontrados nas ruas - suas dimensões são menores e eles são colocados próximos às construções, evitando assim que interrompam a passagem. Na viela avaliada, os postes não configuravam um entrave à circulação; no entanto, nas vielas mais estreitas, é recomendável que a fiação seja enterrada, para eliminar esses obstáculos.

Outro tipo de obstáculo comum nas vielas são degraus ou pequenas rampas, existentes nas entradas de algumas das construções. Há, ainda, caixas de concreto que abrigam os medidores de água, como pode ser visto nas imagens ao lado.

Uma vez que o espaço disponível nas vielas não é muito grande, seu uso não está muito atrelado a atividades de permanência, mas principalmente a circulação. O levantamento de fluxos permite identificar a importância dessas áreas no tecido urbano da favela, principalmente para o tráfego de pedestres.

A contagem de fluxo permite identificar que a circulação de pedestres nas vielas é bastante intensa, pelo menos em se tratando das vielas principais, de maiores dimensões, como a avaliada. Por hora, passa pela viela mais da metade da quantidade de pedestres que circulam pela rua no mesmo período. Assim, esse espaço é utilizado intensamente por toda a população, não apenas por aqueles que
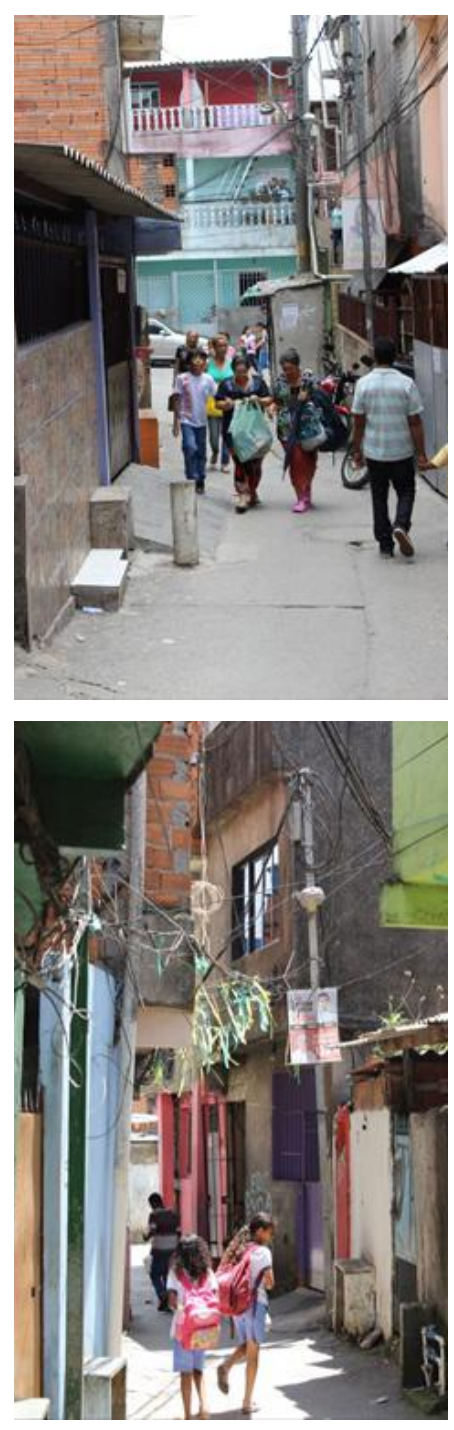

Figuras 46 e 47: Obstáculos nas vielas. Fonte: Fotos de Cláudia Carunchio. 


\section{ANÁLISE QUALITATIVA DOS ESPAÇOS PÚBLICOS - VIELA}

\begin{tabular}{|c|c|c|c|c|c|c|}
\hline Pontos a serem observados & $\checkmark$ & \pm & $\mathrm{X}$ & Fluxos & Em 4min & Em 1h \\
\hline Iluminação pública & & & $x$ & Pedestres & 52 & 780 \\
\hline Atrativos verdes & & & $\mathrm{x}$ & Automóveis & 0 & 0 \\
\hline Uso do solo diversificado & & & $\mathrm{x}$ & Ônibus & 0 & 0 \\
\hline Transparência nas fachadas & & & $\mathrm{x}$ & Caminhões & 0 & 0 \\
\hline Fluxo de pedestres separado do de veículos & & $\mathrm{x}$ & & Motocicletas & 0 & 0 \\
\hline Proteção contra sol e chuva & & & $\mathrm{x}$ & Bicicletas & 0 & 0 \\
\hline Fachadas atrativas & & & $x$ & \\
\hline Espaços adequados para caminhar & & & $x$ & \multirow{8}{*}{\multicolumn{3}{|c|}{$\begin{array}{l}\text { - não é exclusiva para o tráfego } \\
\text { de pedestres (baixo fluxo de } \\
\text { automóveis e motocicletas, mas } \\
\text { há tráfego nos trechos em que a } \\
\text { largura da viela é suficiente para } \\
\text { a passagem desses veículos); } \\
\text { - presença de água acumulada } \\
\text { em diversos trechos. }\end{array}$}} \\
\hline Espaços de permanência & & & $\mathrm{x}$ & & & \\
\hline Espaço para recreação & & & $\mathrm{x}$ & & & \\
\hline Espaço para a prática de atividades físicas & & & $\mathrm{x}$ & & & \\
\hline Mobiliário Urbano & & & $x$ & & & \\
\hline Linhas de visão & & & $\mathrm{x}$ & & & \\
\hline Baixos níveis de ruídos & $x$ & & & & & \\
\hline Piso regular & & & $\mathrm{x}$ & & & \\
\hline Tipo de piso adequado & & $x$ & & & & \\
\hline Lixeiras & & & $\mathrm{x}$ & & & \\
\hline Ausência de lixo no chão & & & $x$ & & & \\
\hline
\end{tabular}

Tabela 14: Análise Paraisópolis com o trecho viela. Fonte: Elaborado por Cláudia Carunchio. moram em alguma das residências voltadas para ele. Ainda que sejam espaços residuais, as vielas apresentam um importante papel no sistema de espaços públicos da favela, uma vez que permite aos pedestres encurtar distâncias, não sendo necessário contornar os quarteirões.

Embora não tenham sido identificados outros modais na contagem de fluxos, sabe-se que as vielas são utilizadas também para a circulação de alguns veículos. Nas vielas mais largas, é possível a entrada de automóveis, como visto anteriormente, ainda que isso seja feito apenas pelos moradores que possuem garagens em suas residências. Entretanto, em grande parte das vielas, há uma pequena circulação de motocicletas, que, como os pedestres, utilizam esses espaços para encurtar distâncias. Isso gera risco de atropelamento aos transeuntes, em um espaço no qual eles deveriam ser priorizados.

Os riscos aos pedestres também estão associados à possibilidade de quedas, que é intensificada pelas irregularidades na pavimentação, como rachaduras e declividades. Assim como foi proposto para as ruas, é recomendável o estabelecimento de um piso de concreto livre de desníveis. É necessário, também, estabelecer um sistema para a drenagem de águas pluviais, já que em diversos trechos há água acumulada, que, além de proporcionar todos os problemas de salubridade associados ao excesso de umidade, aumenta o risco de quedas. 
A segurança foi apontada pelos moradores como um dos principais problemas da favela, principalmente nas vielas e à noite. O próprio traçado desses espaços contribui para que eles sejam inseguros, uma vez que seu formato orgânico proporciona pouca visibilidade do percurso. Isso é agravado pela falta de iluminação pública, que torna esses espaços ainda mais vulneráveis após o entardecer. Em vista disso, recomenda-se a colocação de luminárias, que podem ser inseridas nos postes já existentes ou apoiadas sobre as próprias construções, para melhorar a segurança à noite sem que seja necessário inserir mais obstáculos no solo.

Ainda que nem sempre seja possível alcançar uma situação ideal no âmbito da ergonomia, ao se entenderem os problemas existentes em cada local e suas implicações, permite-se elaborar propostas que minimizem suas deficiências e que atendam às demandas existentes, estabelecendo espaços mais adequados às necessidades dos usuários.

\section{Algumas considerações}

As favelas configuram ambientes urbanos muito distintos das tipologias encontradas na cidade formal. Esses espaços apresentam diversas precariedades, relacionadas à carência de infraestrutura e às condições ruins de salubridade, que comprometem a qualidade de vida da população. No entanto, existem também potenciais, que poderiam ser mais bem aproveitados caso houvesse mais propostas de intervenção que visem à adequação do espaço às necessidades dos moradores. Considerando a grande parcela da população que vive em favelas e ao caráter consolidado de muitos desses assentamentos, é essencial desenvolver projetos que atuem sobre esses espaços, qualificando-os em seus diversos aspectos.

Dadas as particularidades da favela, intervenções nesse ambiente não podem ser realizadas apenas com referência no que é desenvolvido em outros locais, reproduzindo padrões da cidade formal. Para que as propostas estejam de acordo com as reais demandas, carências e possibilidades da favela, é necessário um entendimento não apenas dos espaços físicos e de suas precariedades e deficiências, mas também das lógicas de ocupação desses espaços e do que os moradores identificam como necessidades.

Além disso, entender não apenas os aspectos físicos do espaço, mas também avaliá-lo qualitativa e quantitativamente, é essencial para se reconhecer suas reais possibilidades. Tendo em vista que algumas áreas da favela estão em uma situação de extrema precariedade e que esse ambiente urbano apresenta uma grande densidade

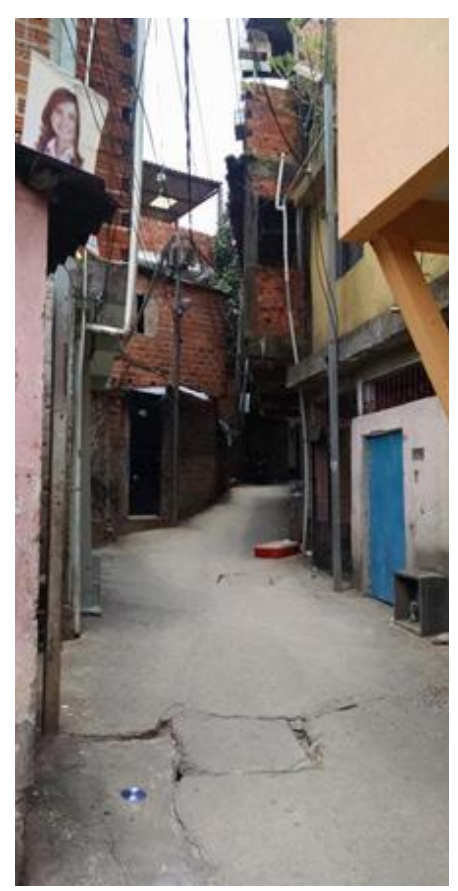

Figura 48: Piso irregular. Fonte: Foto de Cláudia Carunchio. 
populacional e construtiva, com poucas áreas livres, em muitos casos não é possível estabelecer, com intervenções pequenas e economicamente viáveis, espaços completamente adequados a todas as tarefas e atividades demandadas. Entretanto, é possível adotar medidas simples que, ainda que não proporcionem um espaço ideal, geram grandes impactos no dia-a-dia dos moradores e em sua qualidade de vida, facilitando a realização de atividades e tarefas cotidianas e tornando a utilização dos espaços mais segura. 


\section{Quadro resumo}

- O método de cálculo dos fluxos de pedestre, utilizados isoladamente, não proporciona a possibilidade de prever a dinâmica de circulação.

- O método de cálculo de fluxos pela densidade trata de uma situação limite, que pode ser questionada com relação aos espaços que ficariam subutilizados na maior parte do temp.

- O cálculo do fluxo de pedestres, é uma pequena parcela do que envolve a acessibilidade dos espaços urbanos. Esta proposição não considera fatores com caráter subjetivo como a percepção do espaço pelo usuário.

- Os critérios de análise atribuídos a região da Bela Vista são, de maneira geral, de situação regular.

- Os critérios na República são avaliados, em geral, de forma negativa.

- A percepção do espaço, para esta pesquisa de aplicação dos Métodos 02 e 03 , baseou-se principalmente na questão visual do ambiente. Assim, fatores como a presença de verde, área de céu visível, uso do solo, fluxo de pedestres e de carros foram os fatores mais relevantes para a classificação.

- Os estudos realizados na Freguesia do Ó, mostram que os ambientes externos à habitação pouco se preocupam com o pedestre.

- Em relação à Consolação, embora com alguns critérios não atendidos, encontramse ambientes mais adequados.
- O espaço urbano é muito mais complexo do que o descrito por variáveis físicas e ambientais.

- As favelas configuram ambientes urbanos muito distintos das tipologias encontradas na cidade formal.

- Esses espaços apresentam diversas precariedades, relacionadas à carência de infraestrutura e às condições ruins de salubridade, que comprometem a qualidade de vida da população.

- Existem também potenciais, que poderiam ser mais bem aproveitados caso houvesse mais propostas de intervenção que visem à adequação do espaço às necessidades dos moradores.

- Apesar da particularidade de cada caso, as conclusões e resultados alcançados em cada pesquisa mostra a necessidade de avaliações não só quantitativas mas também qualitativas.

- Apesar destes critérios apontarem alguns aspectos relacionados à percepção, denota-se a necessidade de investigar de forma mais direta como se dá a percepção dos usuários dos espaços pesquisados e até que ponto os critérios quantitativos refletem e auxiliam nestes levantamentos.

- Este contraponto entre os aspectos quantitativos, qualitativos e os usuários é de extrema importância não só para a efetiva avaliação destes espaços, mas principalmente para a efetiva construção de espaços urbanos mais agradáveis. 


\section{Proposta de método para avaliação ergonômica do ambiente}

urbano

Neste capitulo apresenta-se o método proposto para avaliação ergonômica do ambiente urbano que considera uma pesquisa descritiva e que tem como principal ferramenta de aplicação a observação e a inquirição (MORAES E MONT'ALVÃO, 2003). Esta proposta de avaliação ergonômica do ambiente urbano possui duas etapas: uma quantitativa e outra qualitativa e foi desenvolvida conforme fluxograma abaixo:

\section{MÉTTODO PROPOSTO}

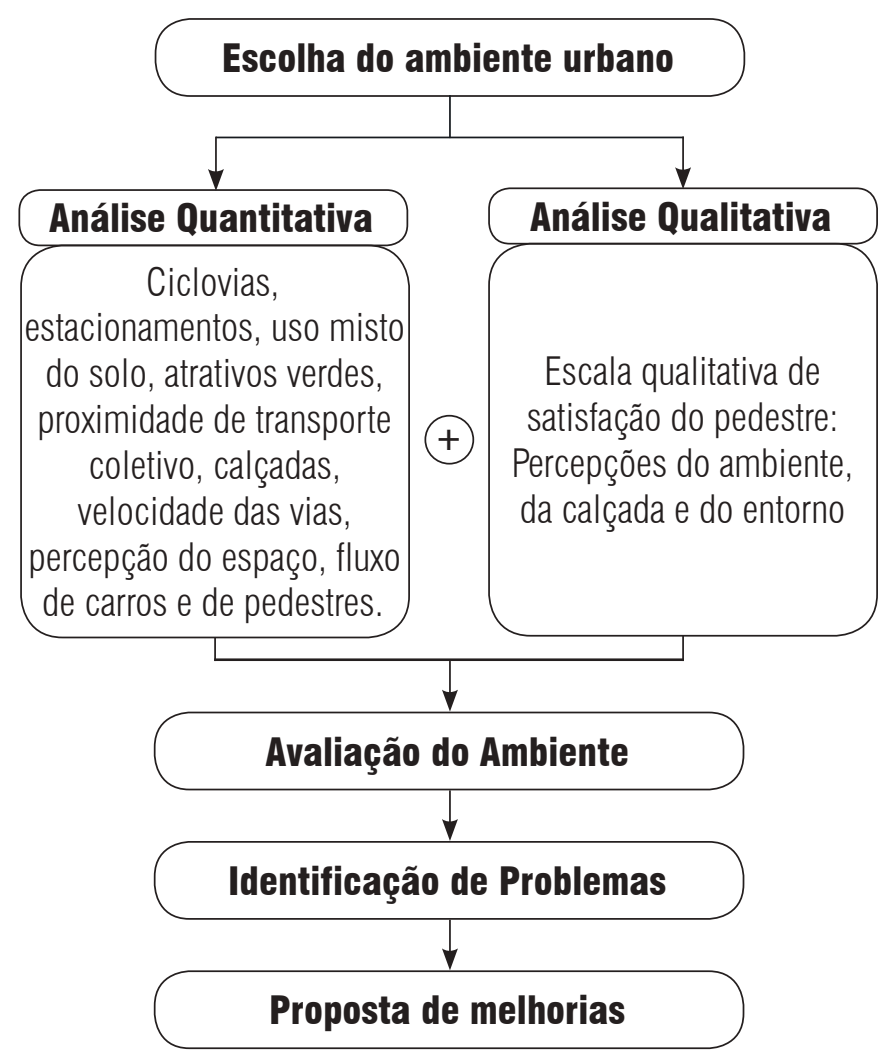

Figura 49: Fluxograma do método proposto. Fonte: Elaborado pela autora. 


\section{Análise quantitativa}

Na etapa quantitativa, utiliza-se tanto a observação como

a inquirição. Neste caso, como ferramentas de inquirição propõe-se a utilização de escalas de avaliação, e classificam-se basicamente os aspectos físicos do ambiente, ou seja, os critérios, estabelecidos dentro de certos parâmetros, presentes ou não no espaço avaliado.

Para esta etapa, foram escolhidos os seguintes critérios:

1) presença de ciclovias;

2) presença de estacionamento;

3) uso misto do solo;

4) presença de atrativos verdes;

5) proximidade aos meios de transporte coletivo;

6) dimensionamento das calçadas;

7) velocidade das vias;

8) percepção do espaço;

9) fluxo de carros; e

10) fluxo de pedestres.

Para alguns critérios específicos do método, contou-se com referências bibliográficas e precedentes metodológicos. Os demais critérios fazem parte desta nova proposta.

Propõe-se a avaliação destes critérios da seguinte forma:

\section{CICLOVIAS}

Este critério avalia a presença de ciclovia, ciclorrota ou ciclofaixa na área a ser avaliada. Propõem-se os seguintes parâmetros de análise:

- Melhor situação: presença de infraestrutura ao ciclista, como ciclofaixa e ciclovia;

- Situação regular: presença de ciclorrota na via, que indica a possibilidade de ciclistas na área;

- Pior situação: indica ausência de qualquer tipo de infraestrutura ao ciclista. 
Tabela 15: Quadro resumo - Ciclovias. Fonte: Elaborado pela autora.

Tabela 16: Quadro resumo - Estacionamentos. Fonte: Elaborado pela autora.

\begin{tabular}{|c|c|c|c|}
\hline Critérios & $\begin{array}{l}\text { Forma de } \\
\text { Avaliação }\end{array}$ & Parâmetros & Ícones \\
\hline \multirow{3}{*}{ Ciclovia } & \multirow{3}{*}{$\begin{array}{c}\text { Observação: } \\
\text { presença } \\
\text { no local de } \\
\text { ciclovias ou } \\
\text { ciclorrotas. } \\
\text { (Pozueta) }\end{array}$} & $\begin{array}{c}\text { Melhor situação: presença de } \\
\text { infraestrutura ao ciclista, como } \\
\text { ciclofaixa e ciclovia }\end{array}$ & \\
\hline & & $\begin{array}{c}\text { Situação regular: presença de } \\
\text { ciclorrota na via, que indica a } \\
\text { possibilidade de ciclistas na } \\
\text { área }\end{array}$ & \\
\hline & & $\begin{array}{c}\text { Pior situação: indica } \\
\text { ausência de qualquer tipo de } \\
\text { infraestrutura ao ciclista }\end{array}$ & \\
\hline
\end{tabular}

\section{ESTACIONAMENTOS}

Este critério avalia a presença ou não dos estacionamentos de carro ao longo da via, partindo do pressuposto que a sua existência incentiva o transporte individual. Também se parte do pressuposto de que o veículo estacionado na rua, ao lado da calçada, torna-se um obstáculo ao pedestre, além de promover uma percepção negativa do espaço. Propõem-se os seguintes parâmetros de análise:

- Melhor situação: ausência de estacionamento ao longo da via;

- Situação regular: permite-se que os carros estacionem em pelo menos um lado da via;

- Pior situação: carros estacionam dos dois lados da via e há presença de estacionamentos na área.

\begin{tabular}{|c|c|c|c|}
\hline Critérios & $\begin{array}{c}\text { Forma de } \\
\text { Avaliação }\end{array}$ & Parâmetros & Ícones \\
\hline & & $\begin{array}{c}\text { Melhor situação: ausência de } \\
\text { estacionamento ao longo da } \\
\text { via }\end{array}$ & \\
\cline { 3 - 5 } Estacio- & $\begin{array}{c}\text { Observação: } \\
\text { presença de } \\
\text { namento } \\
\text { estaciona- } \\
\text { mento na via. }\end{array}$ & $\begin{array}{c}\text { Situação regular: permite-se } \\
\text { que os carros estacionem em } \\
\text { pelo menos um lado da via }\end{array}$ & \\
\cline { 3 - 5 } & $\begin{array}{c}\text { Situação regular: permite-se } \\
\text { que os carros estacionem em } \\
\text { pelo menos um lado da via }\end{array}$ & \\
\hline
\end{tabular}




\section{USO MISTO DO SOLO}

Este critério avalia a presença de uso misto do solo no local avaliado, a partir do pressuposto que somente um tipo de uso incentiva o uso do transporte individual. Por exemplo, um bairro predominantemente residencial determina que seus moradores devam se deslocar para ter acesso a serviços básicos, desde supermercado, padaria, até mesmo ao local de trabalho e estudo. Uma área em que o uso do solo é bem variado promove, portanto, uma menor necessidade de deslocamento de longas distâncias para fazer o necessário da rotina diária. Propõem-se os seguintes parâmetros de análise:

- Melhor situação: diversos usos do solo na área;

- Situação regular: pelo menos dois tipos de uso do solo;

- Pior situação: apenas um uso do solo.

\begin{tabular}{|c|c|c|c|}
\hline Critérios & $\begin{array}{l}\text { Forma de } \\
\text { Avaliação }\end{array}$ & Parâmetros & Ícones \\
\hline \multirow{3}{*}{$\begin{array}{l}\text { Uso misto } \\
\text { do solo }\end{array}$} & \multirow{3}{*}{$\begin{array}{l}\text { Observação: } \\
\text { presença de } \\
\text { variedade de } \\
\text { usos no local } \\
\text { (residencial, } \\
\text { comercial e } \\
\text { de serviços) } \\
\text { (Pozueta) }\end{array}$} & $\begin{array}{l}\text { Melhor situação: diversos usos } \\
\text { do solo na área }\end{array}$ & \\
\hline & & $\begin{array}{l}\text { Situação regular: pelo menos } \\
\text { dois tipos de uso do solo }\end{array}$ & \\
\hline & & $\begin{array}{l}\text { Pior situação: apenas um uso } \\
\text { do solo }\end{array}$ & \\
\hline
\end{tabular}

Tabela 17: Quadro resumo - Uso misto do solo. Fonte: Elaborado pela autora.

\section{PRESENÇA DE ATRATIVOS VERDES}

A presença de verde no percurso é importante tanto na questão sensorial, na percepção do espaço, como na questão do conforto térmico. Propõem-se os seguintes parâmetros de análise:

- Melhor situação: é visível uma grande predominância de vegetação na área;

- Situação regular: há presença de vegetação na área;

- Pior situação: a vegetação é praticamente ausente na área. 
Tabela 18: Quadro resumo Presença de atrativos verdes. Fonte: Elaborado pela autora.

\begin{tabular}{|c|c|c|c|}
\hline Critérios & $\begin{array}{l}\text { Forma de } \\
\text { Avaliação }\end{array}$ & Parâmetros & Ícones \\
\hline \multirow{3}{*}{$\begin{array}{l}\text { Presença } \\
\text { de } \\
\text { atrativos } \\
\text { verdes }\end{array}$} & \multirow{3}{*}{$\begin{array}{l}\text { Observação: } \\
\text { presença de } \\
\text { vegetação na } \\
\text { calçada ou } \\
\text { em canteiros } \\
\text { junto ao leito } \\
\text { carroçável. } \\
\text { (Southworth) }\end{array}$} & $\begin{array}{c}\text { Melhor situação: é visível uma } \\
\text { grande predominância de } \\
\text { vegetação na área }\end{array}$ & \\
\hline & & $\begin{array}{c}\text { Situação regular: há presença } \\
\text { de vegetação na área }\end{array}$ & \\
\hline & & $\begin{array}{l}\text { Pior situação: a vegetação é } \\
\text { praticamente ausente na área }\end{array}$ & \\
\hline
\end{tabular}

\section{PROXIMIDADE A MEIOS DE TRANSPORTES COLETIVOS}

A proximidade a meios de transporte é relevante já que isso pode promover um estimulo na escolha deste sobre o transporte privado. Os parâmetros sugeridos têm como base a distância de acesso ao transporte coletivo, a pé, de $300 \mathrm{~m}$ (aproximadamente 5 minutos de caminhada). Esse valor aumenta para $500 \mathrm{~m}$ para acessar o transporte público sobre trilhos. Propõem-se os seguintes parâmetros de análise:

- Melhor situação: distância ao ponto de ônibus 'de até $150 \mathrm{~m}$ da estação de metrô de até $250 \mathrm{~m}$;

- Situação regular: distância ao ponto de ônibus de até $300 \mathrm{~m}$, da estação de metrô de até $500 \mathrm{~m}$;

- Pior situação: distância ao ponto de ônibus superior à $300 \mathrm{~m}$, da estação de metrô superior à $500 \mathrm{~m}$.
Tabela 19: Quadro resumo - Proximidade a meios de transporte coletivo. Fonte: Elaborado pela autora.

\begin{tabular}{|c|c|c|c|}
\hline Critérios & $\begin{array}{l}\text { Forma de } \\
\text { Avaliação }\end{array}$ & Parâmetros & Ícones \\
\hline \multirow{3}{*}{$\begin{array}{l}\text { Meios } \\
\text { de trans- } \\
\text { porte } \\
\text { coletivo }\end{array}$} & \multirow{3}{*}{$\begin{array}{l}\text { Medição: } \\
\text { distância } \\
\text { do local até } \\
\text { ponto de } \\
\text { ônibus e } \\
\text { metrô/trem. } \\
\text { Distância até } \\
\text { o transporte } \\
\text { coletivo, a pé, } \\
\text { de 300m ou } \\
\text { 500m quando } \\
\text { sobre trilhos. } \\
\text { (Kenworthy) }\end{array}$} & $\begin{array}{c}\text { Melhor situação: distância ao } \\
\text { ponto de ônibus de até } 150 \mathrm{~m} \\
\text { da estação de metrô de até } \\
250 \mathrm{~m}\end{array}$ & \\
\hline & & $\begin{array}{c}\text { Situação regular: distância ao } \\
\text { ponto de ônibus de até } 300 \mathrm{~m} \text {, } \\
\text { da estação de metrô de até } \\
500 \mathrm{~m}\end{array}$ & \\
\hline & & $\begin{array}{c}\text { Pior situação: distância ao } \\
\text { ponto de ônibus superior à } \\
300 \mathrm{~m} \text {, da estação de metrô } \\
\text { superior à } 500 \mathrm{~m}\end{array}$ & \\
\hline
\end{tabular}




\section{CALÇADAS}

Para teste critério, será avaliada sua situação quanto à adequação a norma da ABNT, que visa um mínimo de $1,20 \mathrm{~m}$ de faixa livre, a partir da fórmula $L=F / K+\sum i \geq 1,20$. Onde: - $L=$ largura da faixa livre;

- K= fluxo de pedestres estimado ou medido nos horários de pico, em pedestres por minuto por metro $(K=25$ pedestres por minuto;

- $\sum \mathrm{i}=$ somatórios dos valores adicionais relativos aos fatores de impedância, sendo: $0,45 \mathrm{~m}$ junto a vitrines ou comércio no alinhamento; $0,25 \mathrm{~m}$ junto ao mobiliário urbano; $0,25 \mathrm{~m}$ junto à entrada de edificações no alinhamento (ABNT 2004). Propõem-se os seguintes parâmetros de análise:

- Melhor situação: calçada dimensionada acima do mínimo necessário $+10 \mathrm{~cm}$;

- Situação regular: calçada dimensionada até mínimo necessário $+10 \mathrm{~cm}$;

- Pior situação: calçada dimensionada abaixo do mínimo necessário.

\begin{tabular}{|c|c|c|c|}
\hline Critérios & $\begin{array}{c}\text { Forma de } \\
\text { Avaliação }\end{array}$ & Parâmetros & Ícones \\
\hline \multirow{6}{*}{ Calçadas } & $\begin{array}{c}\text { Melhor situação: calçada di- } \\
\text { mensionada acima do mínimo } \\
\text { necessário }+10 \mathrm{~cm}\end{array}$ & \\
& \begin{tabular}{c} 
Medição da \\
largura da \\
calçada \\
$\mathrm{L}=\mathrm{F} / \mathrm{K}+\sum \mathrm{i}$ \\
$\geq 1,20$. \\
\cline { 3 - 4 }
\end{tabular} & $\begin{array}{c}\text { Situação regular: calçada } \\
\text { dimensionada até mínimo } \\
\text { necessário }+10 \mathrm{~cm}\end{array}$ & \\
\cline { 3 - 5 } & ABNT 2004) & $\begin{array}{c}\text { Pior situação: calçada } \\
\text { dimensionada abaixo do } \\
\text { mínimo necessário }\end{array}$ & \\
\hline
\end{tabular}

Tabela 20: Quadro resumo - Calçadas. Fonte: Elaborado pela autora.

\section{VELOCIDADE DAS VIAS}

O critério da velocidade da via na qual o pedestre se encontra relaciona-se com a segurança do pedestre ao utilizá-la. O leito carroçável é um obstáculo ao pedestre e quanto maior a velocidade permitida aos meios motorizados, menor é a segurança do pedestre. Propõem-se para este critério os seguintes parâmetros de análise:

- Melhor situação: limite de $30 \mathrm{~km} / \mathrm{h}$.

- Situação regular: limite de $40 \mathrm{~km} / \mathrm{h}$

- Pior situação: limite de $60 \mathrm{~km} / \mathrm{h}$ ou mais 
Tabela 21: Quadro resumo - Velocidade das vias. Fonte: Elaborado pela autora.

\begin{tabular}{|c|c|c|c|}
\hline Critérios & $\begin{array}{l}\text { Forma de } \\
\text { Avaliação }\end{array}$ & Parâmetros & Ícones \\
\hline \multirow{3}{*}{$\begin{array}{c}\text { Velocidade } \\
\text { das vias }\end{array}$} & \multirow{3}{*}{$\begin{array}{l}\text { Medição da } \\
\text { velocidade } \\
\text { dos veículos } \\
\text { na via (sensor } \\
\text { velocidade). }\end{array}$} & $\begin{array}{l}\text { Melhor situação: limite de } \\
30 \mathrm{~km} / \mathrm{h}\end{array}$ & \\
\hline & & $\begin{array}{l}\text { Situação regular: limite de } \\
\qquad 40 \mathrm{~km} / \mathrm{h}\end{array}$ & \\
\hline & & $\begin{array}{l}\text { Pior situação: limite de } \\
60 \mathrm{~km} / \mathrm{h} \text { ou mais }\end{array}$ & \\
\hline
\end{tabular}

\section{PERCEPÇÃO DO ESPAÇO}

A sensação do espaço transmitida ao pedestre na interação de alguns critérios pode ser avaliada a partir da situação da calçada, abóboda de céu visível no nível da via, fluxo de carros e a presença de atrativos verdes. Apesar da percepção ser avaliada neste método de forma mais abrangente, incluindo vários outros critérios, optou-se por quantificar estes critérios citados como forma de aferir alguns aspectos da percepção. Propõemse para este critério os seguintes parâmetros de análise ${ }^{16}$ :

- Melhor situação: presença de muito verde, calçada de tamanho adequada, recuo dos prédios permitindo uma ampla visão do céu, baixo fluxo de carros;

- Situação regular: presença regular de verde, fluxo de carros médio/alto, visão da abóboda celeste afetada pelos edifícios;

- Pior situação: ausência de verde, calçada subdimensionada, visão restringida do céu, alto fluxo de carros.
Tabela 22: Quadro resumo Percepção do espaço. Fonte: Elaborado pela autora.
[16] Observação: para classificação da situação encontrada, é necessário que todos os parâmetros propostos sejam atendidos.

\begin{tabular}{|c|c|c|c|}
\hline Critérios & $\begin{array}{l}\text { Forma de } \\
\text { Avaliação }\end{array}$ & Parâmetros & Ícones \\
\hline \multirow{3}{*}{$\begin{array}{l}\text { Percepção } \\
\text { do espaço }\end{array}$} & \multirow{3}{*}{$\begin{array}{l}\text { Observação, } \\
\text { medição, } \\
\text { e analise } \\
\text { fotográfica } \\
\text { lente fisheye } \\
180^{\circ} \text { abóboda } \\
\text { de céu visível. }\end{array}$} & $\begin{array}{l}\text { Melhor situação: presença de } \\
\text { muito verde, calçada de tamanho } \\
\text { adequada, recuo dos prédios } \\
\text { permitindo uma ampla visão do } \\
\text { céu, baixo fluxo de carros }\end{array}$ & \\
\hline & & $\begin{array}{l}\text { Situação regular: presença } \\
\text { regular de verde, fluxo de carros } \\
\text { médio/alto, visão da abóboda } \\
\text { celeste afetada pelos edifícios }\end{array}$ & \\
\hline & & $\begin{array}{l}\text { Pior situação: ausência de verde, } \\
\text { calçada subdimensionada, visão } \\
\text { restringida do céu, alto fluxo de } \\
\text { carros }\end{array}$ & \\
\hline
\end{tabular}




\section{FLUXO DE CARROS}

Para a avaliação do fluxo de carros na via avaliada, pretendese classificar a via pelo número de carros por hora, dentro dos seguintes parâmetros:

\section{Classificação:}

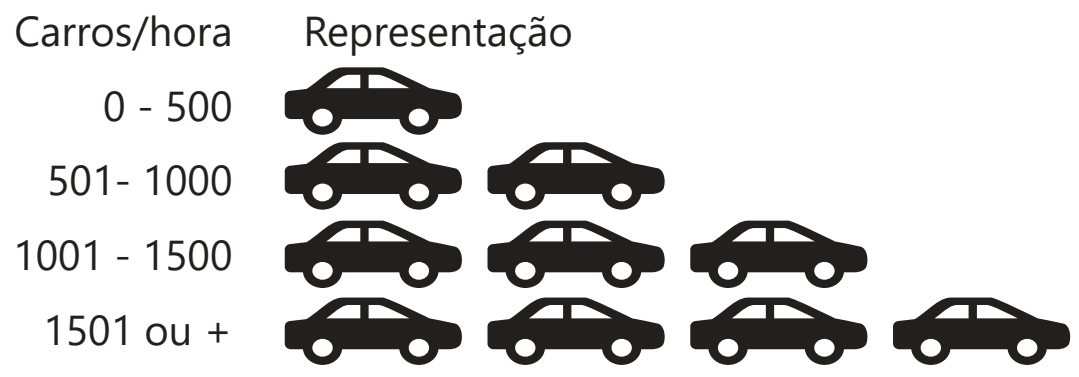

\begin{tabular}{|c|c|c|c|}
\hline Critérios & $\begin{array}{l}\text { Forma de } \\
\text { Avaliação }\end{array}$ & Parâmetros & Ícones \\
\hline \multirow{4}{*}{$\begin{array}{c}\text { Fluxo de } \\
\text { carros }\end{array}$} & \multirow{4}{*}{$\begin{array}{c}\text { Medição: } \\
\text { contagem } \\
\text { de veículos } \\
\text { por hora } \\
\text { (Southworth) }\end{array}$} & 0 - 500 carros/hora & همه \\
\hline & & 501 - 1000 carros/hora & क्षि \\
\hline & & 1001 - 1500 carros/hora & क्षित \\
\hline & & 1501 ou + carros/hora & 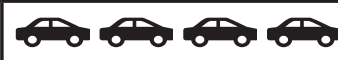 \\
\hline
\end{tabular}

Tabela 23: Quadro resumo - Fluxo de carros. Fonte: Elaborado pela autora.

\section{FLUXO DE PEDESTRES}

Para a avaliação do fluxo de pedestre na calçada avaliada, pretende-se classifica-la pelo número de pedestres por hora, dentro dos seguintes parâmetros

\section{Classificação:}

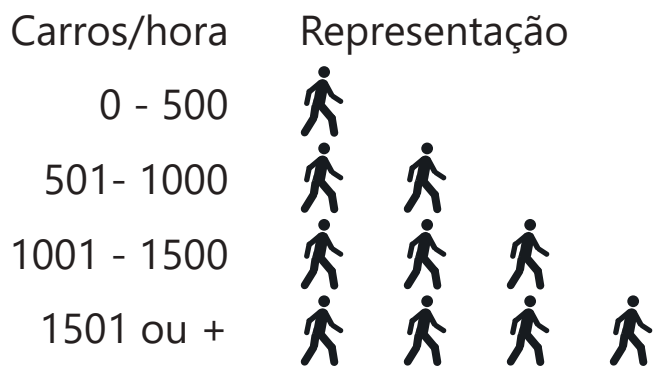

\begin{tabular}{|c|c|c|c|}
\hline Critérios & $\begin{array}{l}\text { Forma de } \\
\text { Avaliação }\end{array}$ & Parâmetros & Ícones \\
\hline \multirow{4}{*}{$\begin{array}{l}\text { Fluxo de } \\
\text { pedestre }\end{array}$} & \multirow{4}{*}{$\begin{array}{l}\text { Medição: } \\
\text { contagem de } \\
\text { pedestres na } \\
\text { via por hora } \\
\text { (Southworth) }\end{array}$} & $0-500$ pessoas/hora & $\dot{\hat{\lambda}}$ \\
\hline & & $501-1000$ pessoas/hora & $\dot{\hat{\lambda}} \dot{\hat{\lambda}}$ \\
\hline & & $1001-1500$ pessoas/hora & $\dot{\hat{\lambda}} \dot{\hat{\lambda}}$ \\
\hline & & 1501 ou + pessoas/hora & $\dot{\hat{\lambda}} \dot{\hat{\lambda}} \dot{\hat{\lambda}}$ \\
\hline
\end{tabular}

Tabela 24: Quadro resumo - Fluxo de pedestre. Fonte: Elaborado pela autora. 
Para a aplicação destes critérios, dentro dos critérios sugeridos, utiliza-se para as medições e/ou observações em campo as seguintes fichas:

Tabelas 25-32: Fichas para aplicação. Fonte: Elaborado pela autora.

\begin{tabular}{|c|c|c|c|c|c|}
\hline \multicolumn{3}{|c|}{ Tres } & \multicolumn{4}{c|}{ ClCLOVIAS } \\
\hline 1 & 2 & 3 & 4 & 5 & Situação \\
\hline & & & & & $\begin{array}{c}\text { Presença de infraestrutura ao ciclista } \\
\text { (ciclofaixa, ciclovia) }\end{array}$ \\
\hline & & & & & $\begin{array}{c}\text { Presença de ciclorota na via - indica a } \\
\text { possibilidade de haver ciclistas }\end{array}$ \\
\hline & & & & & Ausência de infraestrutura ao ciclista \\
\hline
\end{tabular}

\begin{tabular}{|c|c|c|c|c|c|}
\hline C & \multicolumn{5}{|c|}{ ESTACIONAMENTOS } \\
\hline \multicolumn{5}{|c|}{ Trecho } & Situação \\
\hline 1 & 2 & 3 & 4 & 5 & Ausência de estacionamentos \\
\hline & & & & & $\begin{array}{c}\text { Veículos podem estacionar em pelo menos } \\
\text { um lado da via }\end{array}$ \\
\hline & & & & & $\begin{array}{c}\text { Veículos podem estacionar nos dois lados da } \\
\text { via e há estacionamentos na área }\end{array}$ \\
\hline
\end{tabular}

\begin{tabular}{|c|c|c|c|c|c|}
\hline \multicolumn{7}{|c|}{} & \multicolumn{2}{c|}{ USO DO SOLO } \\
\hline \multicolumn{7}{|c|}{ Trecho } & Situação \\
\hline 1 & 2 & 3 & 4 & 5 & Diversos usos do solo \\
\hline & & & & & Pelo menos dois tipos de uso \\
\hline & & & & & Apenas um uso \\
\hline & & & & & \\
\hline
\end{tabular}

\begin{tabular}{|c|c|c|c|c|c|}
\hline \multicolumn{7}{|c|}{ Trecho } & \multicolumn{2}{c|}{ ATRATIVOS VERDES } \\
\hline 1 & 2 & 3 & 4 & 5 & Situação \\
\hline & & & & & $\begin{array}{c}\text { É visível uma grande predominância de } \\
\text { vegetação na área }\end{array}$ \\
\hline & & & & & Há presença de vegetação na área \\
\hline & & & & & Vegetação praticamente ausente na área \\
\hline
\end{tabular}




\begin{tabular}{|c|c|c|c|c|c|}
\hline \multicolumn{7}{|c|}{ Trech } & \multicolumn{5}{|c|}{ MEIOS DE TRANSPORTE COLETIVO } \\
\hline 1 & 2 & 3 & 4 & 5 & Situação \\
\hline & & & & & $\begin{array}{c}\text { Distância ao ponto de ônibus de até } 150 \mathrm{~m} ; \\
\text { ao metrô de até } 250 \mathrm{~m}\end{array}$ \\
\hline & & & & & $\begin{array}{c}\text { Distância ao ponto de ônibus de até } 300 \mathrm{~m} \text {; } \\
\text { ao metrô de até } 500 \mathrm{~m}\end{array}$ \\
\hline & & & & & $\begin{array}{c}\text { Distância ao ponto de ônibus superior à } \\
300 \mathrm{~m} ; \text { ao metrô superior à } 500 \mathrm{~m}\end{array}$ \\
\hline
\end{tabular}

\begin{tabular}{|c|c|c|c|c|c|}
\hline \multicolumn{5}{|c|}{ Trech/h } & \multicolumn{5}{c|}{ VELOCIDADE NA VIA } \\
\hline 1 & 2 & 3 & 4 & 5 & Situação \\
\hline & & & & & Limite de $30 \mathrm{~km} / \mathrm{h}$ \\
\hline & & & & & Limite de $40 \mathrm{~km} / \mathrm{h}$ \\
\hline & & & & & Limite de $60 \mathrm{~km} / \mathrm{h}$ ou mais \\
\hline
\end{tabular}

\begin{tabular}{|c|c|c|}
\hline \multirow{2}{*}{ A. } & \multicolumn{2}{|c|}{ LARGURA DAS CALÇADAS } \\
\hline Trecho & Lado & \multicolumn{1}{|c|}{ Largura } \\
\hline \multirow{2}{*}{1} & Esquerdo & \\
\hline \multirow{2}{*}{2} & Direito & \\
\cline { 2 - 2 } & Esquerdo & \\
\hline \multirow{2}{*}{3} & Direito & \\
\cline { 2 - 2 } & Esquerdo & \\
\hline \multirow{2}{*}{4} & Direito & \\
\cline { 2 - 2 } & Esquerdo & \\
\cline { 2 - 3 } & Direito & \\
\hline
\end{tabular}

\begin{tabular}{|c|c|c|c|c|c|c|c|c|c|}
\hline \multicolumn{2}{|c|}{$\underset{0}{\circ}$} & \multicolumn{8}{|c|}{ FLUXOS } \\
\hline \multirow{2}{*}{ Trecho } & \multirow{2}{*}{ Horário } & \multicolumn{4}{|c|}{ Pedestres } & \multicolumn{4}{|c|}{ Veículos } \\
\hline & & 1 & 2 & 3 & Total & 1 & 2 & 3 & To tal \\
\hline \multicolumn{10}{|l|}{1} \\
\hline & & & & & & & & & \\
\hline \multicolumn{10}{|l|}{2} \\
\hline & & & & & & & & & \\
\hline \multicolumn{10}{|l|}{3} \\
\hline & & & & & & & & & \\
\hline 4 & & & & & & & & & \\
\hline
\end{tabular}




\section{Análise qualitativa}

$\mathrm{N}^{a}$ a etapa qualitativa, propõe-se a avaliação da percepção do usuário sobre o espaço em questão. Nesta utiliza-se tanto a observação como a inquirição. Neste caso, como ferramentas da inquirição propõe-se a utilização de entrevistas, verbalizações, questionários e escalas de avaliação. Convém observar que as escalas de avaliação, aplicada nesta etapa qualitativa, tem o objetivo de correlacionar os resultados das entrevistas e/ou questionários, ou seja, da percepção do usuário com valores preestabelecidos em normas, na legislação ou aferidos no local. Esta correlação da percepção do usuário com escalas de avaliação também proporcionam a possibilidade de avaliação conjunta dos aspectos de desempenho ergonômicos e o conforto ambiental como um todo, destacando as questões de conforto térmico, acústico e luminoso.

A seguir, consideram-se os procedimentos para consideração da percepção do pedestre.

A Tabela 33 apresenta as questões de percepção ambiental,

Tabela 33: Questionário para entrevista de percepção ambiental do pedestre. Fonte:

Elaborado pela autora.

\begin{tabular}{|l|l|}
\hline \multicolumn{2}{|c|}{ Questões da entrevista de percepção ambiental do pedestre } \\
\hline Q.1 & Como você se sente em relação a este local? \\
\hline Q.2 & Como você se sente em relação a beleza deste local? \\
\hline Q.3 & Como você se sente em relação a qualidade do ar deste local? \\
\hline Q.4 & Como você se sente em relação ao nível de ruído desse local? \\
\hline Q.5 & Como você se sente em relação à quantidade de luz deste local? \\
\hline Q.6 & Como você se sente em relação à temperatura do ar deste local? \\
\hline Q.7 & Como você se sente em relação à umidade do ar deste local? \\
\hline Q.8 & Como você se sente em relação à exposição ao sol neste local? \\
\hline Q.9 & Como você se sente em relação à exposição ao vento neste local? \\
\hline Q.10 & $\begin{array}{l}\text { Como você se sente em relação ao risco de atropelamento } \\
\text { neste local? }\end{array}$ \\
\hline Q.11 & Como você se sente em relação ao risco de assalto neste local? \\
\hline Q.12 & Como você se sente em relação à calçada? \\
\hline Q.13 & $\begin{array}{l}\text { Como você se sente em relação ao espaço para circulação na } \\
\text { calçada? }\end{array}$ \\
\hline Q.14 & Como você se sente em relação ao piso da calçada? \\
\hline Q.15 & Como você se sente em relação à vegetação no local? \\
\hline Q.16 & Como você se sente em relação aos assentos existentes no local? \\
\hline Q.17 & Como você se sente em relação às lixeiras existentes no local? \\
\hline Q.18 & De quais serviços você sente falta na região? \\
\hline
\end{tabular}


considerando-se as perguntas constantes na entrevista. Para cada uma das questões, excetuando-se a última, o pedestre entrevistado declarava o seu grau de satisfação indicando a imagem de sua preferência para aquela situação.

A Figura 50 ilustra as cinco opções de imagens disponíveis para serem indicadas pelo entrevistado em cada questão.
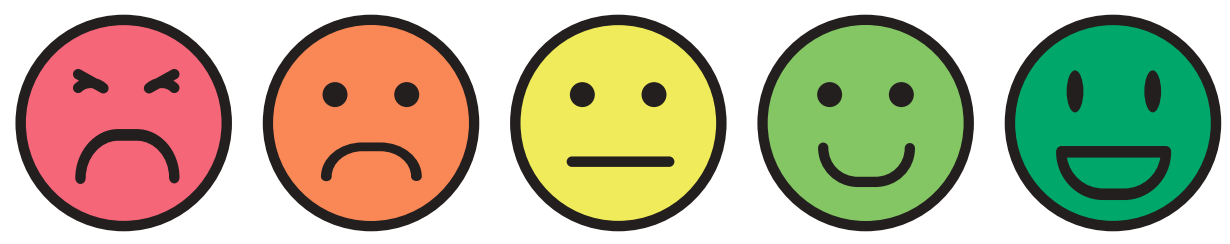

\begin{tabular}{|c|c|c|c|}
\hline \multicolumn{4}{|c|}{ DADOS GERAIS } \\
\hline Local: & & Horário: & \\
\hline \multicolumn{4}{|c|}{ DADOS DO ENTREVISTADO } \\
\hline Idade: & & \multicolumn{2}{|c|}{ Sexo: ( ) Masculino ( ) Feminino } \\
\hline \multicolumn{2}{|c|}{$\begin{array}{l}\text { Qual meio de transporte } \\
\text { utiliza no dia-a-dia? }\end{array}$} & \multicolumn{2}{|c|}{$\begin{array}{l}\text { ( ) a pé ( ) bicicleta ( ) moto } \\
\text { ( ) automóvel ( ) transp. público } \\
\text { ( ) outros }\end{array}$} \\
\hline \multicolumn{4}{|c|}{ PERCEPÇÕES DO AMBIENTE } \\
\hline Geral & $(2): \odot \odot ;$ & Sol & $(2):-(;): 0$ \\
\hline Beleza & $(2):-(;)$ & Vento & 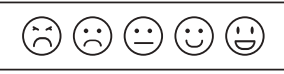 \\
\hline Qualidade do ar & $(2):-(;):-$ & Atropelamento & $(2):(;) ;:)$ \\
\hline Ruído & $(2):-;:)$ & Assalto & $(2):-(;):$ \\
\hline Claridade & $(2):-(;) ;$ & Prédios & $\theta:(:) ;()$ \\
\hline Temperatura & $(2):-(;) ;$ & Verde & $(2):(;) ;:)$ \\
\hline \multicolumn{4}{|c|}{ PERCEPÇÕES DA CALÇADA } \\
\hline Geral & $(2):-(;) ;$ & Bancos & 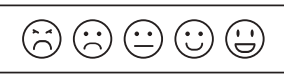 \\
\hline Largura & $(2):-(;) ;$ & Lixeiras & $(2):-(;)$ \\
\hline Piso & $(2):-(;) ;()$ & Obstáculos & $(2):(;) ;()$ \\
\hline \multicolumn{4}{|c|}{ PERCEPÇÕES DO ENTORNO } \\
\hline $\begin{array}{l}\text { Sente falta } \\
\text { desses } \\
\text { serviços? }\end{array}$ & \multicolumn{3}{|c|}{$\begin{array}{c}\text { ( ) Bancos ( ) Restaurantes ( ) Bares } \\
\text { ( ) Farmácias ( ) Mercados ( ) Correios } \\
\text { ( ) Lotéricas ( ) Outros }\end{array}$} \\
\hline
\end{tabular}

Assim, esse método permite a avaliação do espaço não apenas por questões técnicas e comparações com padrões normatizados, mas também considerando os problemas apontados por quem usa o espaço, o que permite a identificação de novas demandas.

A seguir, no Capítulo 06, será a apresentada aplicação do método de avaliação ergonômica do ambiente urbano aqui proposto.
Figura 50: Escala qualitativa de satisfação do pedestre para as questões da entrevista. Fonte: Elaborado pela autora.

Figura 51: Questões da entrevista em formato de aplicação para os pedestres. Fonte: Elaborado pela autora. 


\section{Quadro resumo}

- O método considera uma pesquisa descritiva e que tem como principal ferramenta de aplicação a observação e a inquirição.

- Este método proposto para a avaliação ergonômica do ambiente urbano possui duas etapas: uma quantitativa e outra qualitativa.

- Para a etapa qualitativa são usados os seguintes critérios:

1) presença de ciclovias;

2) presença de estacionamento;

3) uso misto do solo;
4) presença de atrativos verdes;

5) proximidade aos meios de transporte coletivo;

6) dimensionamento das calçadas;

7) velocidade das vias;

8) percepção do espaço;

9) fluxo de carros; e

10) fluxo de pedestres.

- $\mathrm{Na}$ etapa qualitativa propõe-se a avaliação da percepção do usuário sobre o espaço em questão através da observação e da inquirição. 
Verificação do método proposto:

Safari Urbano
[15] Foi realizado pela equipe do Laboratório de Conforto Ambiental e Eficiência Energética da FAU USP no entorno da estação Berrini da CPTM.
$\mathrm{O}$ método aqui aplicado teve como projeto piloto o Safári Urbano realizado junto ao Fit Cities 2014 ${ }^{15}$. Foram selecionados cinco pontos para a aplicação de fichas, medições e realização de entrevistas: a calçada ao lado da Estação Berrini da CPTM, a R. Flórida, a Av. Eng. Luis Carlos Berrini, a R. Arandu e a Praça General Gentil Falcão.

As fichas aplicadas nesses locais são aquelas referentes às análises quantitativas já apresentadas aqui no capítulo anterior. Incluem a existência de ciclovias, de estacionamentos, de atrativos verdes, a velocidade de vias, os fluxos de pedestres e veículos, a variedade de usos do solo, a largura das calçadas, a proximidade aos meios de transporte público e a presença e adequação de obstáculos fixos e móveis nos passeios. As entrevistas, por sua vez, abrangem principalmente a satisfação acústica, térmica e luminosa dos pedestres nos espaços avaliados (Tabela 34).
Tabela 34: Modelo das entrevistas utilizado no Safári Urbano realizado pelo Laboratório de Conforto Ambiental e Eficiência Energética da Faculdade de Arquitetura e Urbanismo da Universidade de São Paulo (LABAUT da FAU USP). Fonte: Modelo produzido pelo próprio LABAUT da FAU USP.

\begin{tabular}{|c|c|c|c|c|c|c|c|c|c|c|c|c|c|c|c|c|c|c|}
\hline \multicolumn{8}{|c|}{ CONTROLE DE DADOS } & \multicolumn{3}{|c|}{$\begin{array}{l}\text { CONFORTO } \\
\text { ACÚSTICO }\end{array}$} & \multicolumn{3}{|c|}{$\begin{array}{c}\text { CONFORTO } \\
\text { TÉRMICO }\end{array}$} & \multicolumn{3}{|c|}{$\begin{array}{l}\text { CONFORTO } \\
\text { LUMINOSO }\end{array}$} & \multicolumn{2}{|c|}{ OBS } \\
\hline & & & & & & & & $A$ & B & C & $D$ & $E$ & $\mathrm{~F}$ & G & $\mathrm{H}$ & & & \\
\hline & 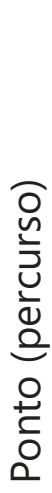 & 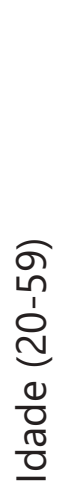 & $\stackrel{\circ}{\stackrel{e}{*}}$ & 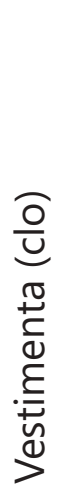 & 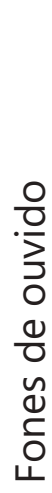 & 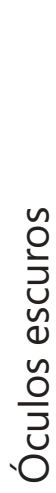 & $\overline{\mathrm{o}}$ & 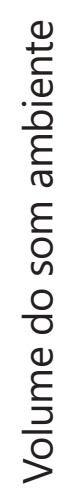 & 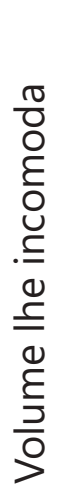 & 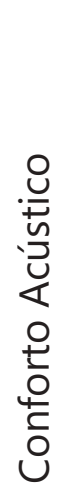 & 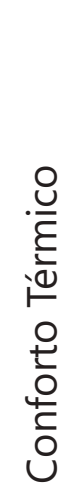 & 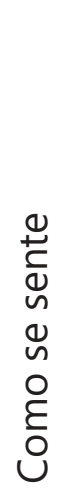 & 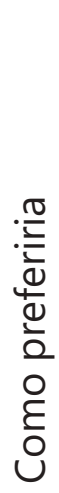 & 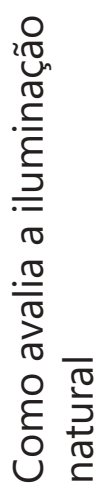 & 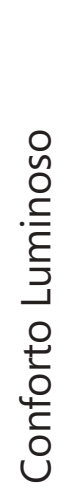 & 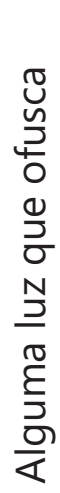 & $\begin{array}{l}\overline{\widetilde{O}} \\
\stackrel{F}{=} \\
\stackrel{0}{0} \\
\text { 오 }\end{array}$ & 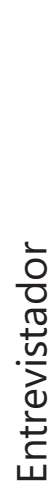 \\
\hline 1 & & & & & & & & & & & & & & & & & & \\
\hline 2 & & & & & & & & & & & & & & & & & & \\
\hline 3 & & & & & & & & & & & & & & & & & & \\
\hline 4 & & & & & & & & & & & & & & & & & & \\
\hline
\end{tabular}


Nessas áreas, ainda se mediu fatores ambientais como temperatura do ar, temperatura do globo, umidade relativa, luminância, luminosidade, ruído e poluição atmosférica. A temperatura do ar e a umidade relativa foram medidos por meio do aparelho termo higrômetro, e obtidos em ${ }^{\circ} \mathrm{C}$ e porcentagem, respectivamente. A temperatura do globo, que inclui a influência de radiação indireta, do vento e da convecção na temperatura, foi obtida pelo uso de um globo preto com um termômetro dentro, em ${ }^{\circ} \mathrm{C}$ também. $\mathrm{O}$ aparelho que mede luminância, que por sua vez representa o reflexo de prédios e superfícies, obteve valores em $\mathrm{cd} / \mathrm{m} 2$. A luminosidade foi obtida pelo luxímetro, que apresenta números em "lux". A quantidade de ruído foi medida pelo aparelho conhecido como sonômetro, cuja grandeza é em $\mathrm{dB}(\mathrm{A})$, ou seja, representa o som que chega nos ouvidos humanos. $O$ medidor de partículas, que se refere à presença de material particulado no ar, apresentava as medidas em $\mu \mathrm{g} / \mathrm{m} 3$.

A avaliação realizada no Safári foi técnica, oriunda principalmente de equipamentos de laboratório e, portanto, seus resultados foram mais quantitativos. Pelos resultados obtidos foi possível observar que as variáveis ergonômicas e os fatores térmicos, acústicos e luminosos estavam em desacordo com as normas de conforto, e os questionários realizados com os usuários pouco refletiram essas condições.

A partir dos resultados, foi feita a tabulação das análises quantitativas de cada situação, de forma sucinta e gráfica, e os resultados foram apresentados no evento Fit Cities São Paulo 2014.

\section{Estação Berrini}

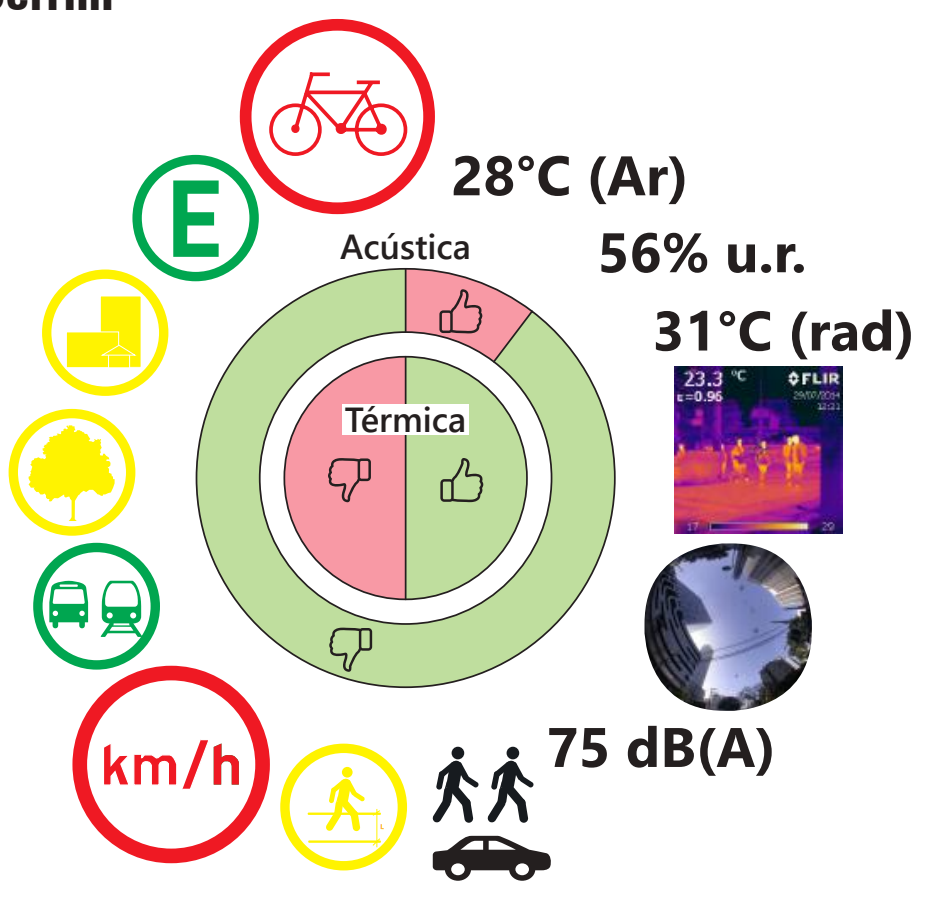




\section{Rua Flórida}

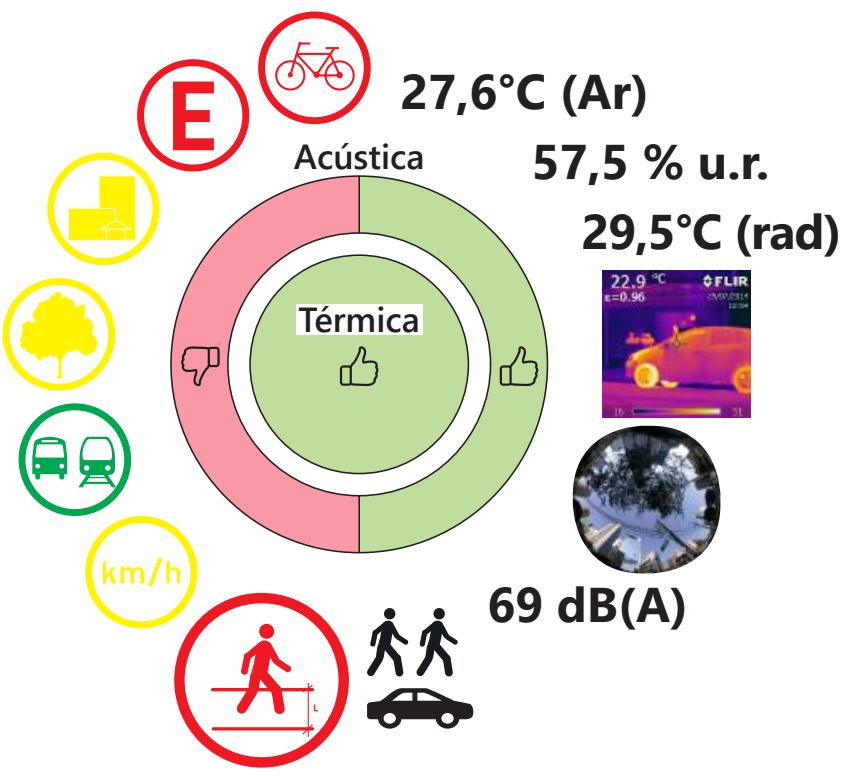

\section{Av. Eng. Luís Carlos Berrini}

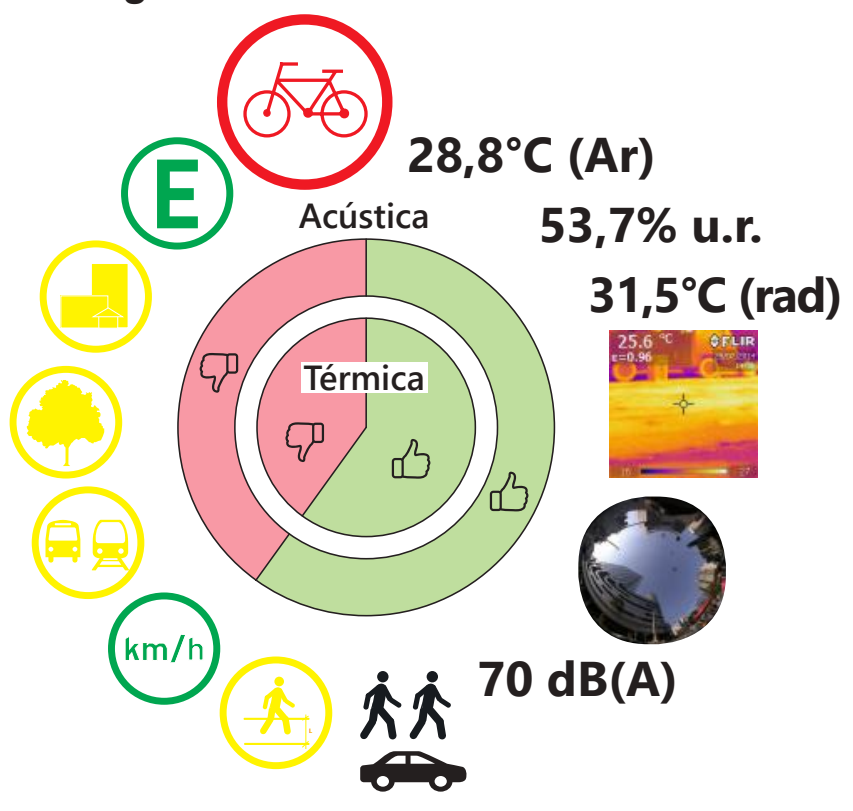

Rua Arandu

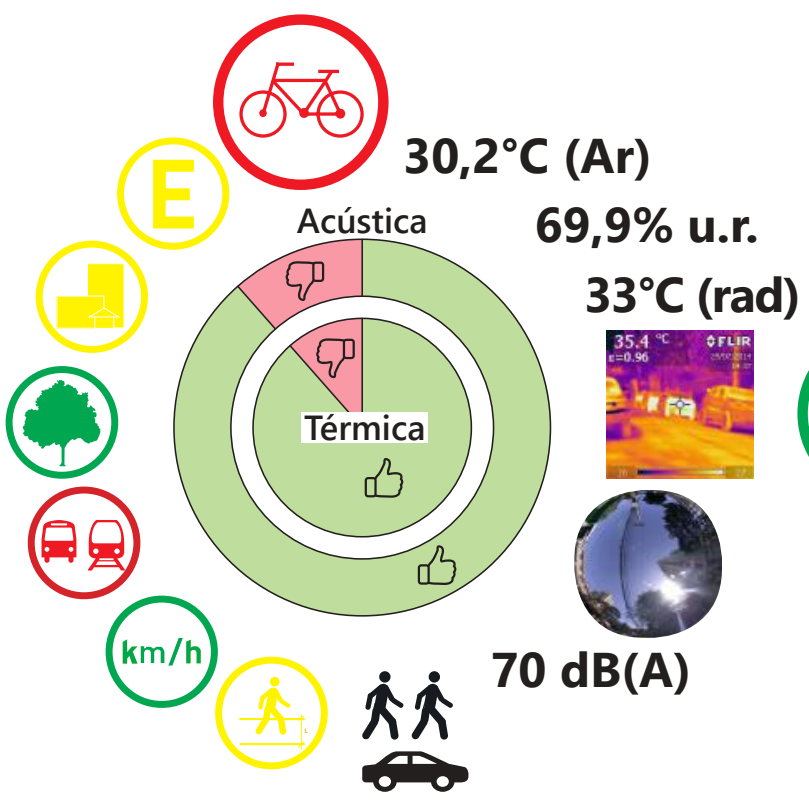

Praça General Gentil Falcão

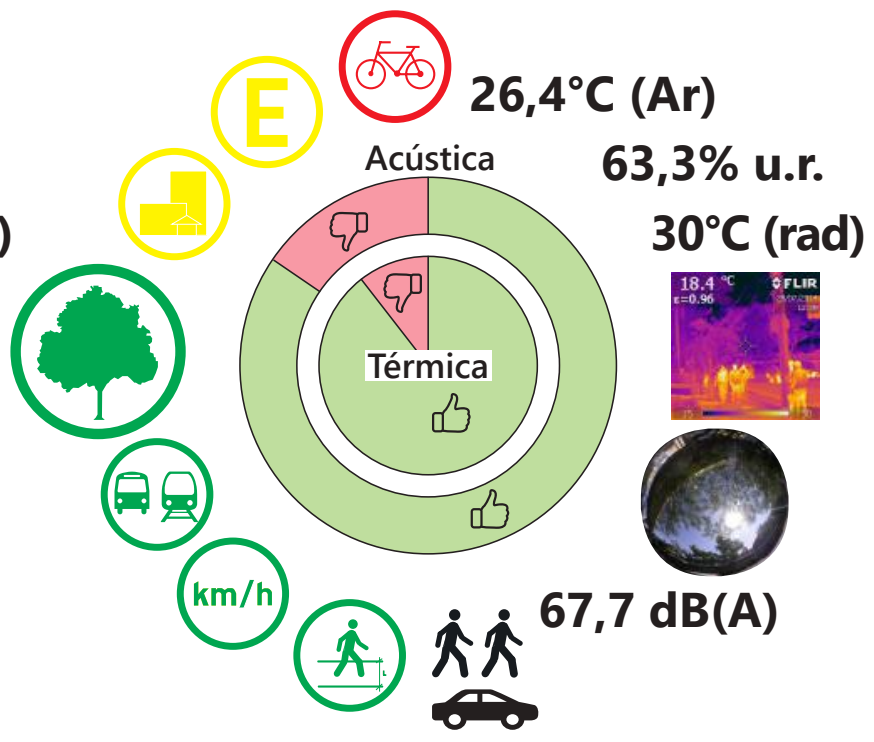

Figura 52: Apresentação resultante da sintetização das análises quantitativas feitas no Safári Urbano. Os resultados numéricos referem-se à temperatura do $\operatorname{ar}\left(\mathrm{em}^{\circ} \mathrm{C}\right)$, umidade relativa (em \%), temperatura do globo (em $\left.{ }^{\circ} \mathrm{C}\right)$ e nível de ruído $(\mathrm{em} \mathrm{dB}(\mathrm{A}))$, respectivamente. Na parte periférica dos gráficos encontra-se as medidas obtidas no Safari. Na parte central, os resultados dos questionários. Fonte: Elaborado por Eduardo Pizarro.

Como desdobramento destas medições, houve a oportunidade de participação na elaboração dos levantamentos de Conforto Ambiental realizado na Marginal Pinheiros da cidade de São Paulo, com o financiamento da Embarq Brasil (Centro de Transporte Sustentável do Brasil) - Diagnóstico Ambiental de espaços 
Figura 53 (Superior esquerda): Estação Berrini e enterno. Fonte: Elaborado por Gabriel Novaes.

Figura 54 (Superior direita): Estação Vila Olímpia e enterno. Fonte: Elaborado por Gabriel

Novaes.

Figura 55 (Inferior): Estação Santo Amaro e enterno. Fonte: Elaborado por Gabriel Novaes.

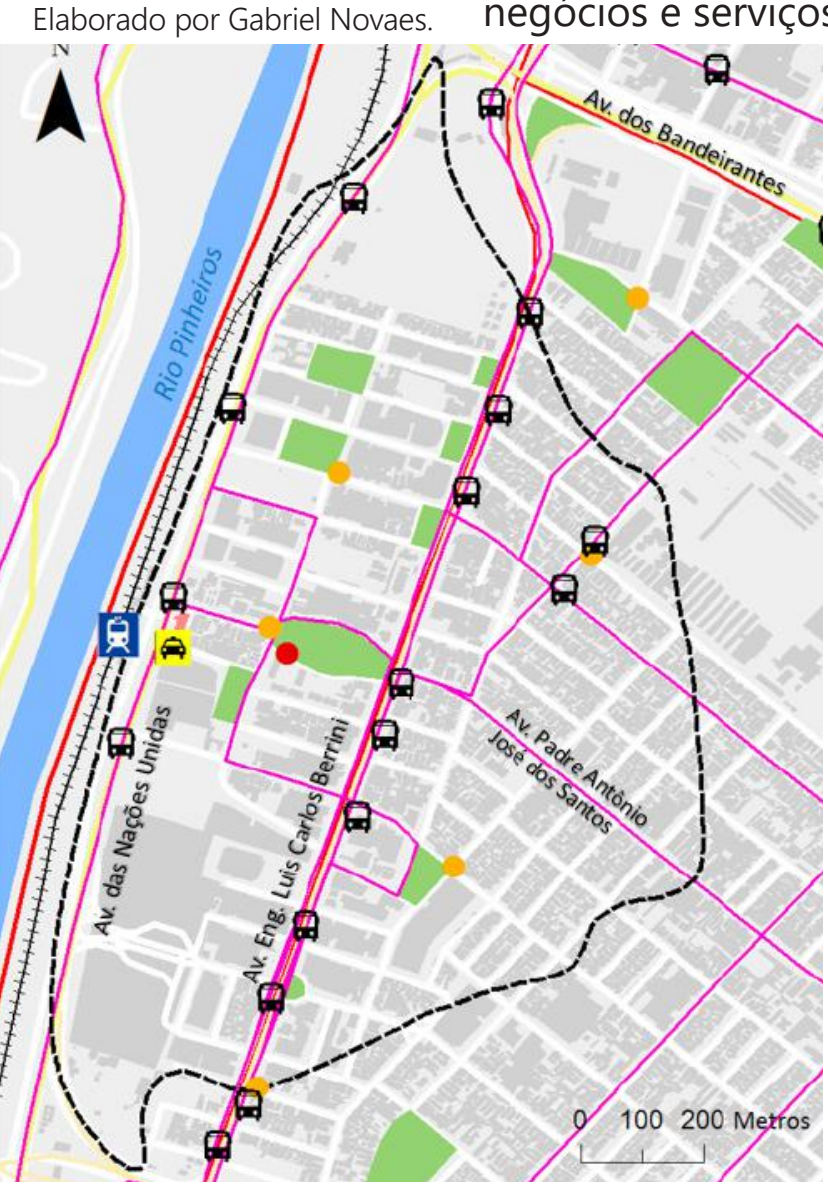

urbanos para desenvolvimento de projetos de microacessibilidade no entorno do Rio Pinheiros. Nesta pesquisa, foi selecionada a área de estudo uma região da qual a Avenida Berrini é o centro, compreendida pela extensão da Marginal Pinheiros, entre as estações Vila Olímpia e Santo Amaro (Figuras 53, 54 e 55). Esta região é caracterizada pelo seu desenvolvimento acentuado nos últimos anos e configura-se hoje em um grande centro de negócios e serviços.

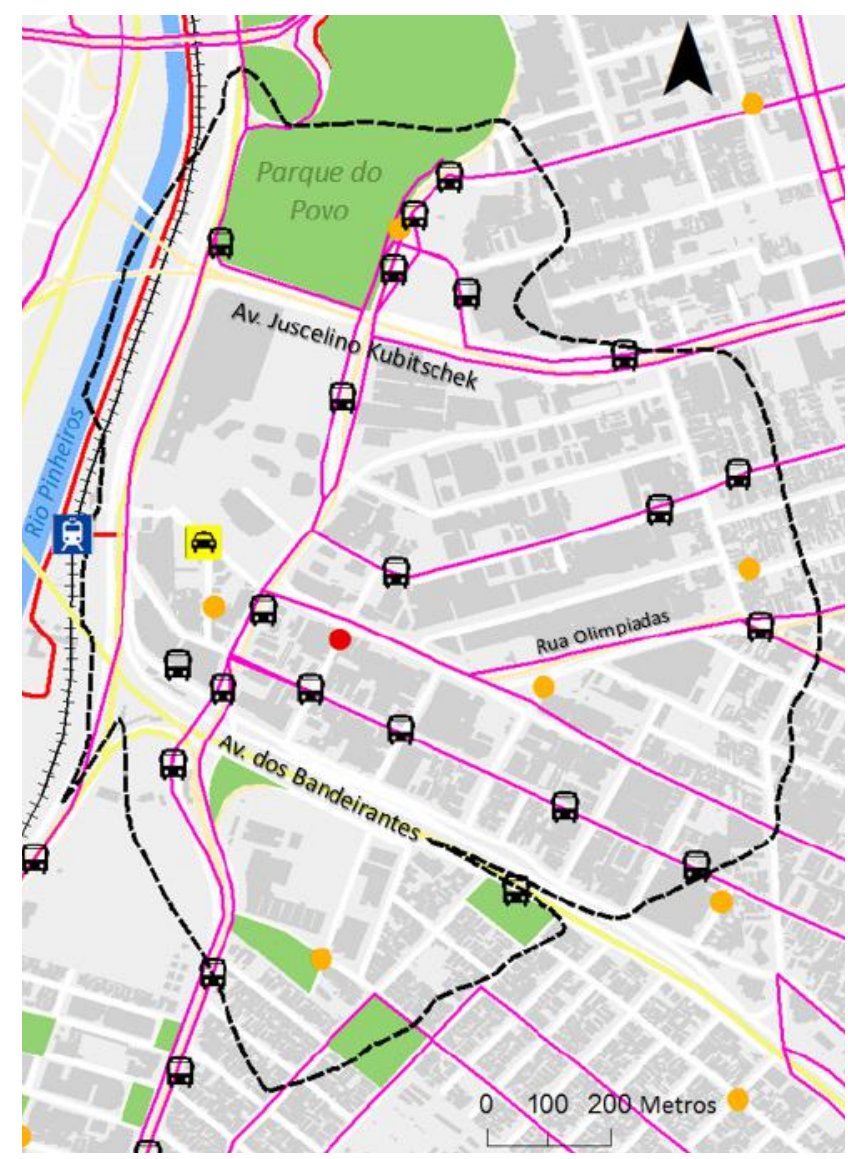

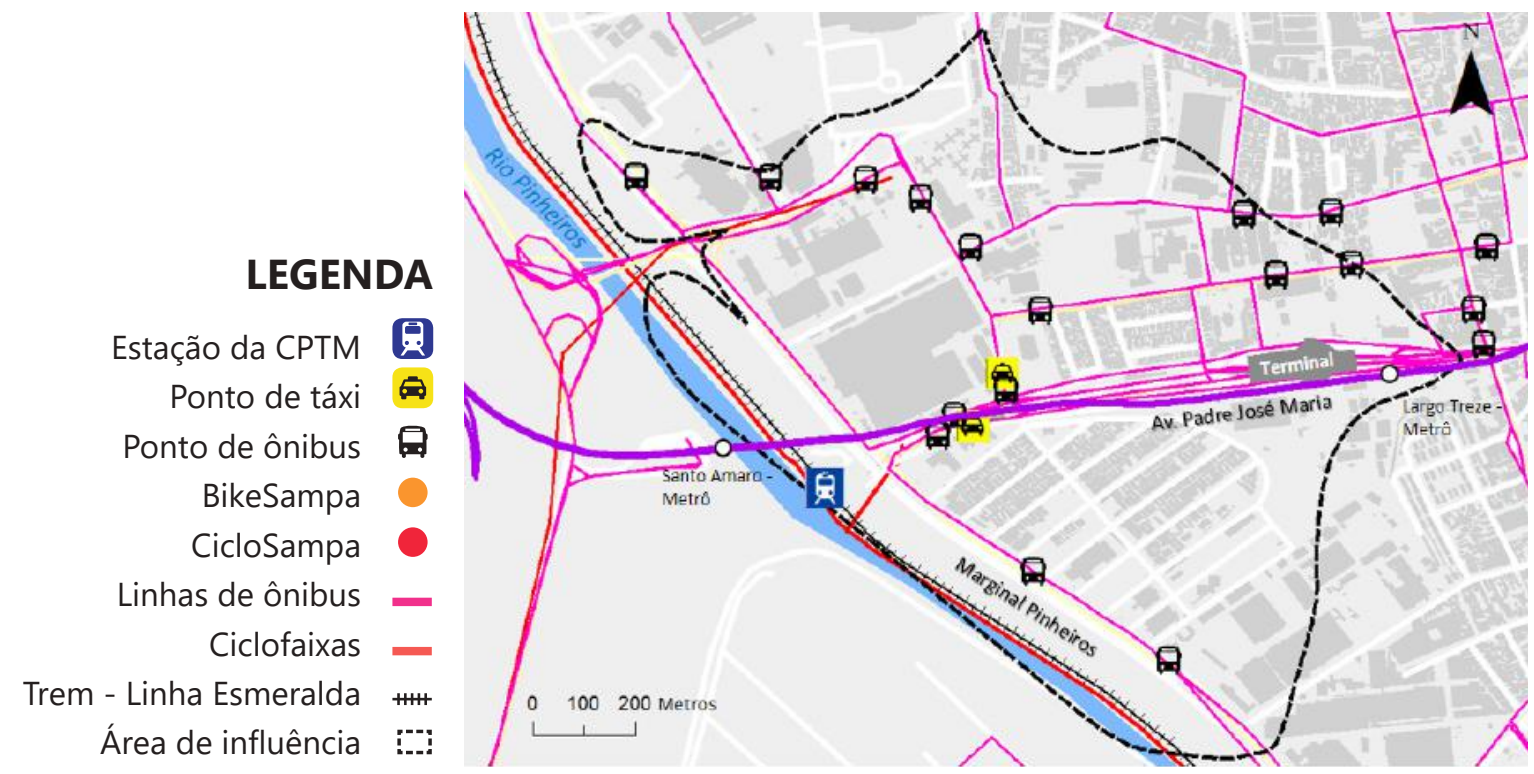


Hoje, a região é um grande polo gerador de viagens em decorrência do surgimento de novas atividades e do crescimento e adensamento local verificados. Isso tem resultado em um aumento acentuado do número de veículos. Por outro lado, o principal modo de acesso à região por transporte coletivo se dá por meio de trem: Linha 9, Esmeralda. Segundo a CPTM (2015) quase meio milhão de passageiros são transportados em média, em dias úteis, pela Linha 9, Esmeralda.

Considerando que a estação Pinheiros sofreu grande processo de intervenção nos últimos anos, ao ser conectada a Linha 4, Amarela, gerando incipientes mudanças na região, este estudo focou em três outras grandes estações em termos de fluxos de usuários da região em análise: Vila Olímpia, Berrini e Santo Amaro.

A seleção das três estações se deu, além do fato da importância em termos de usuários do sistema de transportes coletivo, também devido ao fato da possibilidade de verificar as condições espaciais e ambientais no entorno dessas estações, entendendo e valorizando a mobilidade das pessoas no ato de caminhar e na percepção delas ao fazê-lo.

O método utilizado para a avaliação ergonômica do ambiente urbano, é constituído por duas partes: uma avaliação dos aspectos físicos do ambiente (quantitativa) e uma avaliação da percepção dos usuários sobre o espaço (qualitativa). Assim, esse método permite a avaliação do espaço não apenas por questões técnicas e comparações com padrões normatizados, mas também considerando os problemas apontados por quem usa o espaço, o que permite a identificação de novas demandas.

Para a avaliação da dimensão humana e as questões de conforto ambiental pertinentes aos espaços urbanos optou-se por avaliar as questões relacionadas à morfologia urbana do local (dimensões, obstáculos, mobiliário urbano, qualidade visual), as questões ambientais (relacionadas com o conforto térmico, visual e sonoro) além da percepção espacial do pedestre em relação ao ambiente em questão, que será considerado no item subsequente.

Desta forma, para cada um dos três trechos de cada estação, foram levantados: a) infraestrutura ao ciclista, b) estacionamento de veículos, c) usos do solo, d) presença de vegetação, d) transportes públicos, e) limite de velocidade de veículos, f) largura de calçadas, g) obstáculos presentes nas calçadas.

Para cada um dos três trechos de cada estação, para o período em torno das $9 \mathrm{~h}, 12 \mathrm{~h}$ e $15 \mathrm{~h}$, foram também levantados: i) fluxo de 
Tabelas 34-41: Fichas para aplicação. Fonte: Elaborado pela autora. veículos e ii) fluxo de pedestres.

A correlação das variáveis de percepção dos usuários com as medições de ergonomia e conforto urbano realizadas podem ser observadas na sequência.

\begin{tabular}{|c|c|c|c|c|c|}
\hline \multicolumn{3}{|c|}{ Tres } & \multicolumn{4}{c|}{ CICLOVIAS } \\
\hline 1 & 2 & 3 & 4 & 5 & Situação \\
\hline & & & & & $\begin{array}{c}\text { Presença de infraestrutura ao ciclista } \\
\text { (ciclofaixa, ciclovia) }\end{array}$ \\
\hline & & & & & $\begin{array}{c}\text { Presença de ciclorota na via - indica a } \\
\text { possibilidade de haver ciclistas }\end{array}$ \\
\hline & & & & & Ausência de infraestrutura ao ciclista \\
\hline
\end{tabular}

\begin{tabular}{|c|c|c|c|c|c|}
\hline C & \multicolumn{5}{|c|}{ ESTACIONAMENTOS } \\
\hline \multicolumn{7}{|c|}{ Trecho } & Situação \\
\hline 1 & 2 & 3 & 4 & 5 & Ausência de estacionamentos \\
\hline & & & & & $\begin{array}{c}\text { Veículos podem estacionar em pelo menos } \\
\text { um lado da via }\end{array}$ \\
\hline & & & & & $\begin{array}{c}\text { Veículos podem estacionar nos dois lados da } \\
\text { via e há estacionamentos na área }\end{array}$ \\
\hline
\end{tabular}

\begin{tabular}{|c|c|c|c|c|c|}
\hline & \multicolumn{5}{c|}{ USO DO SOLO } \\
\hline & \multicolumn{5}{|c|}{ Trecho } \\
\hline 1 & 2 & 3 & 4 & 5 & Situação \\
\hline & & & & & Diversos usos do solo \\
\hline & & & & & Pelo menos dois tipos de uso \\
\hline & & & & & Apenas um uso \\
\hline
\end{tabular}

\begin{tabular}{|c|c|c|c|c|c|}
\hline \multicolumn{7}{|c|}{ Trecho } & \multicolumn{3}{c|}{ ATRATIVOS VERDES } \\
\hline 1 & 2 & 3 & 4 & 5 & Situação \\
\hline & & & & & $\begin{array}{c}\text { É visível uma grande predominância de } \\
\text { vegetação na área }\end{array}$ \\
\hline & & & & & Há presença de vegetação na área \\
\hline & & & & & Vegetação praticamente ausente na área \\
\hline
\end{tabular}




\begin{tabular}{|c|c|c|c|c|c|}
\hline \multicolumn{7}{|c|}{ Trech } & \multicolumn{5}{|c|}{ MEIOS DE TRANSPORTE COLETIVO } \\
\hline 1 & 2 & 3 & 4 & 5 & Situação \\
\hline & & & & & $\begin{array}{c}\text { Distância ao ponto de ônibus de até } 150 \mathrm{~m} ; \\
\text { ao metrô de até } 250 \mathrm{~m}\end{array}$ \\
\hline & & & & & $\begin{array}{c}\text { Distância ao ponto de ônibus de até } 300 \mathrm{~m} \text {; } \\
\text { ao metrô de até } 500 \mathrm{~m}\end{array}$ \\
\hline & & & & & $\begin{array}{c}\text { Distância ao ponto de ônibus superior à } \\
300 \mathrm{~m} ; \text { ao metrô superior à } 500 \mathrm{~m}\end{array}$ \\
\hline
\end{tabular}

\begin{tabular}{|c|c|c|c|c|c|}
\hline \multicolumn{5}{|c|}{ Trech/h } & \multicolumn{5}{c|}{ VELOCIDADE NA VIA } \\
\hline 1 & 2 & 3 & 4 & 5 & Situação \\
\hline & & & & & Limite de $30 \mathrm{~km} / \mathrm{h}$ \\
\hline & & & & & Limite de $40 \mathrm{~km} / \mathrm{h}$ \\
\hline & & & & & Limite de $60 \mathrm{~km} / \mathrm{h}$ ou mais \\
\hline
\end{tabular}

\begin{tabular}{|c|c|c|}
\hline \multirow{2}{*}{ A. } & \multicolumn{2}{|c|}{ LARGURA DAS CALÇADAS } \\
\hline Trecho & Lado & \multicolumn{1}{|c|}{ Largura } \\
\hline \multirow{2}{*}{1} & Esquerdo & \\
\hline \multirow{2}{*}{2} & Direito & \\
\cline { 2 - 2 } & Esquerdo & \\
\hline \multirow{2}{*}{3} & Direito & \\
\cline { 2 - 2 } & Esquerdo & \\
\hline \multirow{2}{*}{4} & Direito & \\
\cline { 2 - 2 } & Esquerdo & \\
\cline { 2 - 3 } & Direito & \\
\hline
\end{tabular}

\begin{tabular}{|c|c|c|c|c|c|c|c|c|c|}
\hline \multicolumn{2}{|c|}{$\underset{0}{\circ}$} & \multicolumn{8}{|c|}{ FLUXOS } \\
\hline \multirow{2}{*}{ Trecho } & \multirow{2}{*}{ Horário } & \multicolumn{4}{|c|}{ Pedestres } & \multicolumn{4}{|c|}{ Veículos } \\
\hline & & 1 & 2 & 3 & Total & 1 & 2 & 3 & To tal \\
\hline \multicolumn{10}{|l|}{1} \\
\hline & & & & & & & & & \\
\hline \multicolumn{10}{|l|}{2} \\
\hline & & & & & & & & & \\
\hline \multicolumn{10}{|l|}{3} \\
\hline & & & & & & & & & \\
\hline 4 & & & & & & & & & \\
\hline
\end{tabular}


Junto a uma saída de cada estação de trem, foi alocada ainda uma estação meteorológica, registrando-se: 1) temperatura do ar, 2) temperatura de globo, 3) umidade relativa do ar, e 4) velocidade do vento, no nível do pedestre. Como a sensação térmica só pode ser descrita pela consideração conjunta das quatro variáveis relacionadas (MONTEIRO E ALUCCI, 2005) considerou-se a utilização de uma temperatura equivalente de sensação térmica, a Temperatura Equivalente Percebida (TEP), que considera a temperatura do ar e também a influência da umidade do ar, da velocidade do ar e da radiação térmica na sensação térmica do pedestre, conforme proposto por Monteiro e Alucci (2009).

Para cada um dos três trechos, em cada estação, foram realizadas ainda medições de I) níveis sonoros e II) luminâncias.

A seguir, consideram-se os procedimentos para consideração da percepção do pedestre.

A Tabela 42 apresenta as questões de percepção ambiental, considerando-se as perguntas constantes na entrevista. A coleta de dados foi realizada em dias uteis, em três horários distintos $(9 \mathrm{~h}$, $12 \mathrm{~h}$ e 15h), e as aplicações foram feitas com, aproximadamente, 300 pessoas em cada uma das três estações objeto desse estudo.

Tabela 42: Questionário para entrevista de percepção ambiental do pedestre. Fonte:

Elaborado pela autora.

\begin{tabular}{|l|l|}
\hline \multicolumn{2}{|c|}{ Questões da entrevista de percepção ambiental do pedestre } \\
\hline Q.1 & Como você se sente em relação a este local? \\
\hline Q.2 & Como você se sente em relação a beleza deste local? \\
\hline Q.3 & Como você se sente em relação a qualidade do ar deste local? \\
\hline Q.4 & Como você se sente em relação ao nível de ruído desse local? \\
\hline Q.5 & Como você se sente em relação à quantidade de luz deste local? \\
\hline Q.6 & Como você se sente em relação à temperatura do ar deste local? \\
\hline Q.7 & Como você se sente em relação à umidade do ar deste local? \\
\hline Q.8 & Como você se sente em relação à exposição ao sol neste local? \\
\hline Q.9 & Como você se sente em relação à exposição ao vento neste local? \\
\hline Q.10 & $\begin{array}{l}\text { Como você se sente em relação ao risco de atropelamento } \\
\text { neste local? }\end{array}$ \\
\hline Q.11 & Como você se sente em relação ao risco de assalto neste local? \\
\hline Q.12 & Como você se sente em relação à calçada? \\
\hline Q.13 & $\begin{array}{l}\text { Como você se sente em relação ao espaço para circulação na } \\
\text { calçada? }\end{array}$ \\
\hline Q.14 & Como você se sente em relação ao piso da calçada? \\
\hline Q.15 & Como você se sente em relação à vegetação no local? \\
\hline Q.16 & Como você se sente em relação aos assentos existentes no local? \\
\hline Q.17 & Como você se sente em relação às lixeiras existentes no local? \\
\hline Q.18 & De quais serviços você sente falta na região? \\
\hline
\end{tabular}


Para cada uma das questões, excetuando-se a última, o pedestre entrevistado declarava o seu grau de satisfação indicando a imagem de sua preferência para aquela situação. A Figura 56 ilustra as cinco opções de imagens disponíveis para serem indicadas pelo entrevistado em cada questão.
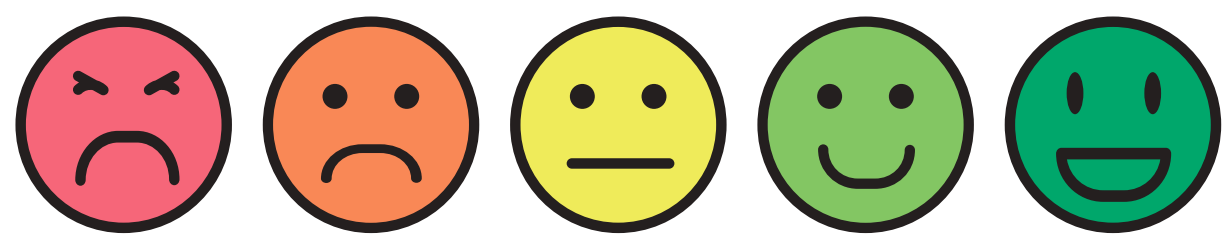

\begin{tabular}{|c|c|c|c|}
\hline \multicolumn{4}{|c|}{ DADOS GERAIS } \\
\hline Local: & & Horário: & \\
\hline \multicolumn{4}{|c|}{ DADOS DO ENTREVISTADO } \\
\hline Idade: & & \multicolumn{2}{|c|}{ Sexo: ( ) Masculino ( ) Feminino } \\
\hline \multicolumn{2}{|c|}{$\begin{array}{l}\text { Qual meio de transporte } \\
\text { utiliza no dia-a-dia? }\end{array}$} & \multicolumn{2}{|c|}{$\begin{array}{l}\text { ( ) a pé ( ) bicicleta ( ) moto } \\
\text { ( ) automóvel ( ) transp. público } \\
\text { ( ) outros }\end{array}$} \\
\hline \multicolumn{4}{|c|}{ PERCEPÇÕES DO AMBIENTE } \\
\hline Geral & $(2):(;) ;$ & Sol & $(2):(;) ;$ \\
\hline Beleza & $(2):(;) ;()$ & Vento & $(2):(;) ;()$ \\
\hline Qualidade do ar & $(2):-(;):()$ & Atropelamento & $(2):-(;):()$ \\
\hline Ruído & $(2):-(;):$ & Assalto & $(2): ;(;) ;()$ \\
\hline Claridade & $(2):-(;):-$ & Prédios & $(2):(;):-()$ \\
\hline Temperatura & $(2):-(;)$ & Verde & $(2):-(;):-$ \\
\hline \multicolumn{4}{|c|}{ PERCEPÇÕES DA CALÇADA } \\
\hline Geral & $(2):(;) ;()$ & Bancos & $(2):(;) ;$ \\
\hline Largura & $(2):(;) ;$ & Lixeiras & $(2):-(;):-$ \\
\hline Piso & $(2):(;) ;$ & Obstáculos & $(2):(;):(2)$ \\
\hline \multicolumn{4}{|c|}{ PERCEPÇÕES DO ENTORNO } \\
\hline $\begin{array}{l}\text { Sente falta } \\
\text { desses } \\
\text { serviços? }\end{array}$ & \multicolumn{3}{|c|}{$\begin{array}{c}\text { ( ) Bancos ( ) Restaurantes ( ) Bares } \\
\text { ( ) Farmácias ( ) Mercados ( ) Correios } \\
\text { ( ) Lotéricas ( ) Outros }\end{array}$} \\
\hline
\end{tabular}

Figura 56: Escala qualitativa de satisfação do pedestre para as questões da entrevista. Fonte: Elaborado pela autora.
Figura 57: Questões da entrevista em formato de aplicação para os pedestres. Fonte: Elaborado pela autora. 


\section{Aplicação do métoodo proposto: Entorno das Estações da CPTM na Marginal Pinheiros}

\section{Entorno da Estação Berrini da CPTM}

Figura 58: Estação Berriri da CPTM e área levantada no EMBARQ Brasil. Fonte: Elaborado por Gabriel Novaes.
Dara a análise do local, definiram-se três trechos para serem avaliados, de modo que, apesar de próximos, cada um apresenta uma situação diferente do espaço urbano. O primeiro trecho escolhido foi a saída da Estação Berrini, do lado da R. Joel Carlos. O segundo foi a calçada da pista local da Marginal Pinheiros, na área em frente ao edifício Plaza Centenário ( $\left.\mathrm{N}^{\circ} 12.995\right)$. E o último, a R. Joel Carlos Borges, abrangendo as construções entre $0 \mathrm{~N}^{\circ}$ 60 e $\mathrm{N}^{\circ}$ 92. As medições foram feitas em três horários diferentes, aproximadamente às $10 \mathrm{~h}, 12 \mathrm{~h}$ e $15 \mathrm{~h}$, em cada trecho. Como a ficha aplicada refere-se mais às características físicas do espaço, a única variável entre esses horários foi o fluxo de pedestres e de veículos.
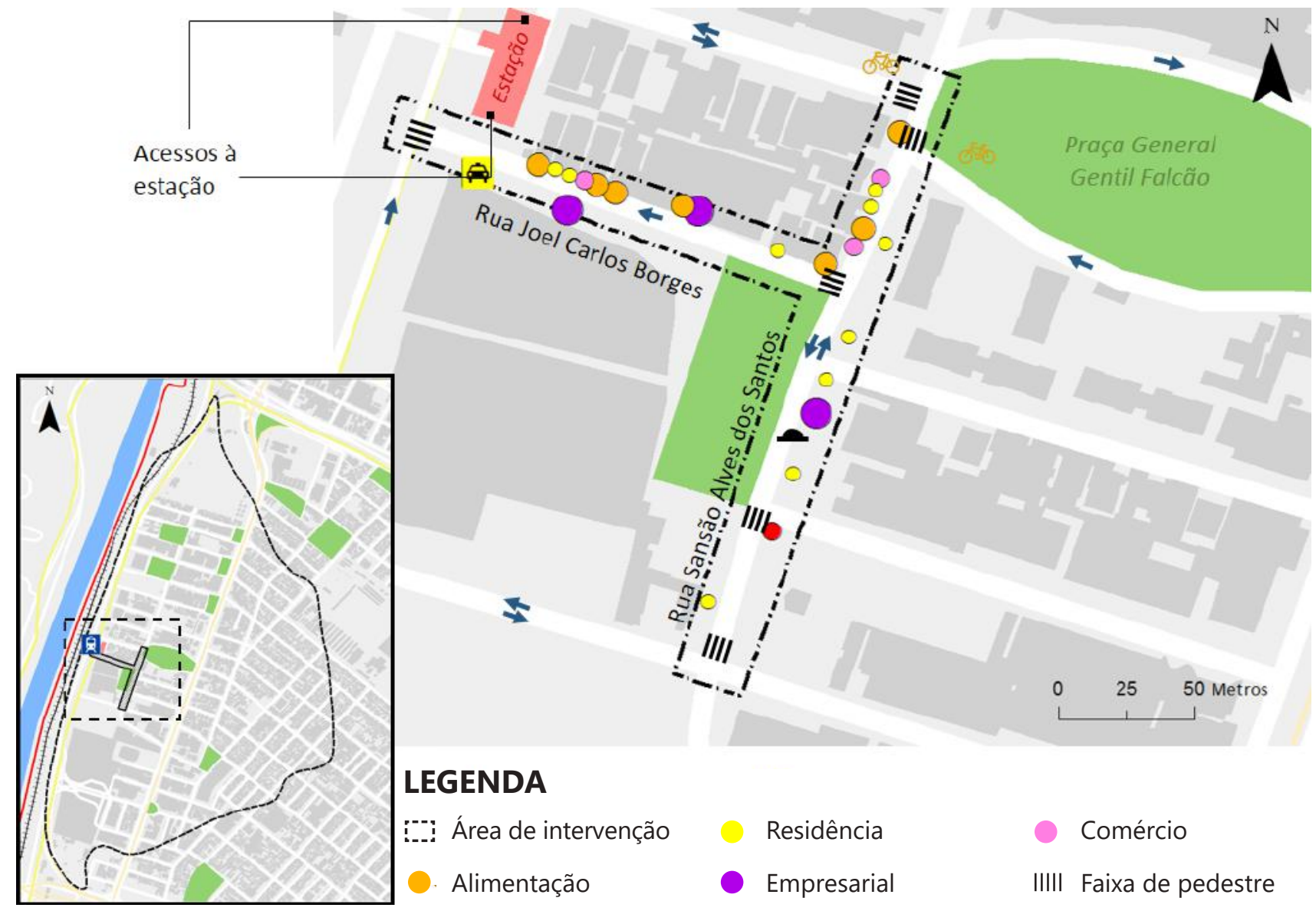

\section{LEGENDA}

:-.: Área de intervenção

Residência

Comércio

Alimentação

Empresarial

IIIII Faixa de pedestre

. Ponto de táxi

Hotel

Bike-share 


\section{Trecho 1: Saída da Estação Berrini, do lado da R. Joel Carlos}

Se comparado aos outros trechos, sua área de abrangência é menor, dado que contém apenas o ambiente imediato à descida da estação de trem. Mesmo assim, essa escolha pareceu-nos válida, por ser um local de intensa passagem dos usuários do transporte e um importante ponto de referência na região. Além da calçada da saída da estação, foram observadas as características do final da $R$. Joel Carlos Borges antes de desembocar na Av. Marginal Pinheiros.

O trecho não possui infraestrutura ao ciclista, como ciclorrotas ou ciclofaixas, e os veículos podem estacionar em um lado da via (lado oposto à Estação Berrini), precisando do Cartão Azul de segunda à sexta, das $7 \mathrm{~h} 00$ às 19h00. Apesar disso, o ambiente estimula o uso do transporte público, pois além de abranger a estação de trem, distancia-se menos de $50 \mathrm{~m}$ dos pontos de ônibus mais próximos, que estão na R. Guilherme Barbosa de Mello e na Av. Marginal Pinheiros.

Devido a curta extensão do trecho, não há muita diversidade do uso do solo: no percurso determinado nota-se um uso de serviço e outro comercial: a própria Estação Berrini da CPTM e o Edifício Plaza Centenário, que se situa em frente à saída da última, respectivamente. Embora não seja abundante, a vegetação na área é visível principalmente nos canteiros e jardins dessas duas construções, de modo que as raízes e copas das árvores e plantas não constituem obstáculos para os pedestres.

O fluxo de veículos é bem baixo, e pouco varia. Nas medições das $10 \mathrm{~h}, 12 \mathrm{~h}$ e $15 \mathrm{~h}$, em uma hora foram contados 36, 72 e 132 veículos, respectivamente. Dentre eles, a maioria era táxi, motos e carros de prestadores de serviços. Em contrapartida, o fluxo de pedestres no local é marcante. A partir da contagem feita perto das 10h, contabilizou-se que, em uma hora, passaram 2.592 pessoas na área. Na medição das $12 \mathrm{~h}$, o número reduziu para 1.440 e na última contagem, às $15 \mathrm{~h}$, foram contados 996 pedestres em uma hora. Uma vez que o trecho se situa em um dos centros comerciais mais importantes da cidade, esses resultados são compreensíveis: os fluxos são mais intensos na hora do começo do expediente de trabalho, reduzindo ao longo do dia. Se houvesse uma contagem próximo às $18 \mathrm{~h}$, no horário do fim de expediente, provavelmente o fluxo também seria notável.

Logo na saída da Estação Berrini, a calçada tem 5,20m. Porém, 
Figuras 59-63: Saída da Estação Berrini, do lado da R. Joel Carlos (Trecho 1). Fonte: Acervo LABAUT. sua largura diminui nas laterais, alcançando $3,05 \mathrm{~m}$ do lado da Av. Marginal Pinheiros e 1,48m no sentido da R. Joel Carlos Borges. Mesmo sendo números relativamente adequados para uma calçada em geral, mostram-se insuficientes para o fluxo de pessoas. Os pedestres acabam utilizando muitas vezes a rua para chegar ao seu destino, desviando de obstáculos como buracos, irregularidades no piso, canteiros de plantas, lixeiras, ambulantes, lixos, postes e placas de sinalização. $\mathrm{O}$ uso das faixas de rolamento para o passeio é facilitado pelo limite de velocidade de $30 \mathrm{~km} / \mathrm{h}$ da R. Joel Carlos Borges, uma vez que é uma rua local. Mesmo com alguns obstáculos, a calçada é pouco inclinada e apresenta a altura correta das guias.
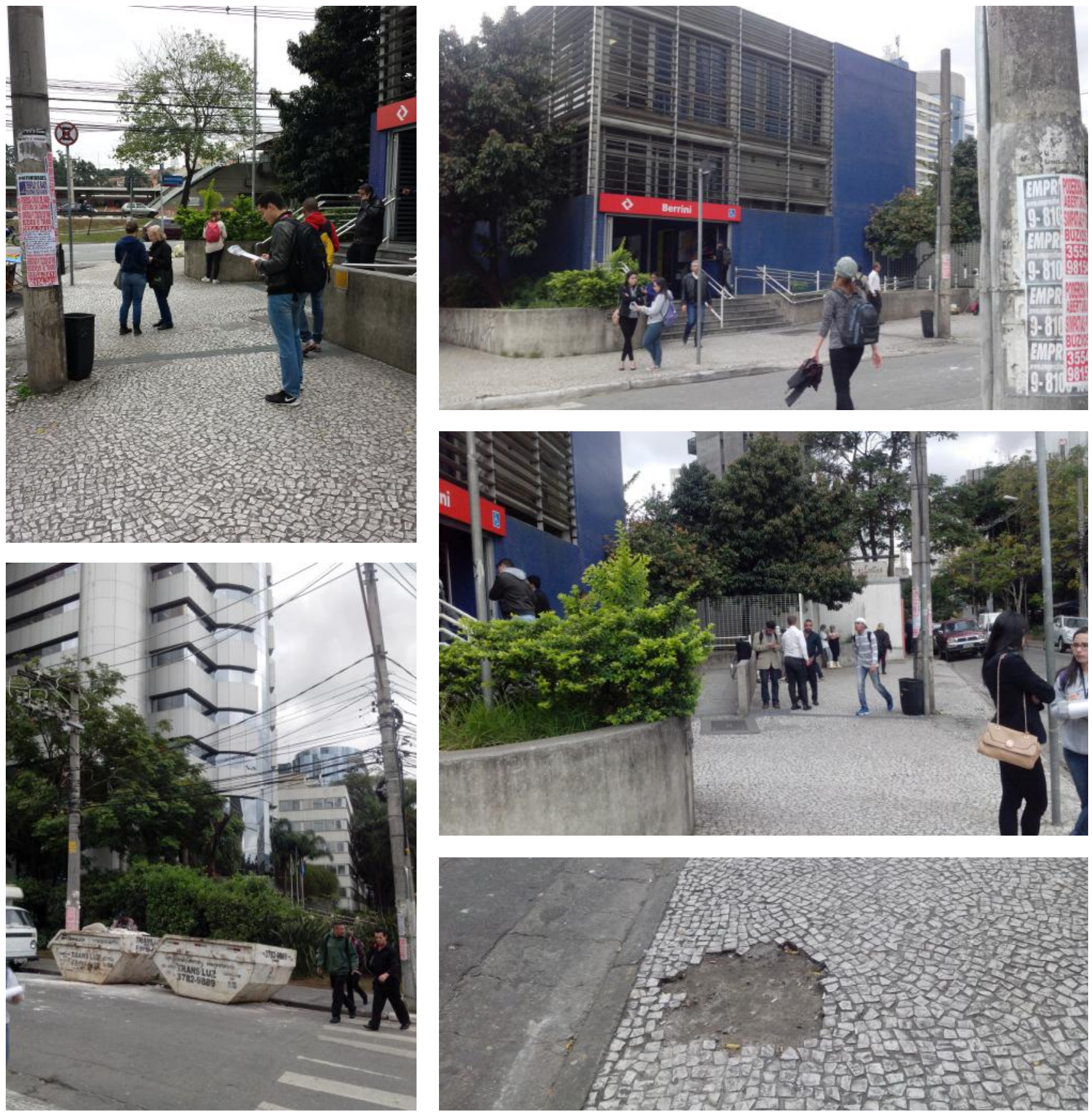

144 Capítulo 6: Aplicação do método de avaliação ergômica do ambiente urbano 


\section{ESTAÇÃO BERRINI DA CPTM}

Trecho 1: Saída da Estação Berrini, do lado da R. Joel Carlos
Ausência de infraestrutura ao ciclista
Os veículos estacionam em um lado da via (lado oposto à Estação
Berrini. O Cartão Azul é necessário de $2^{\circ}$ a $6^{\circ}$ feira, das 7h-19h
Há dois usos de solo no trecho: um comercial e outro de
serviços

Tabela 43: Tabela síntese dos questionários aplicados no Trecho 1 da Estação Berrini. Fonte: Elaborado pela autora. 


\title{
Trecho 2: Calçada da pista local da Av. Marginal Pinheiros, em frente ao Edifício Plaza Centenário
}

\begin{abstract}
A - observar a quantidade de pessoas que saíam e entravam na Estação Berrini da CPTM, notou-se que grande parte do fluxo era oriundo ou se direcionava à calçada da pista local da Av. Marginal Pinheiros. Sendo assim, a escolha desse trecho pareceunos essencial para avaliar o caminho que a maioria dos pedestres da região utiliza rotineiramente. Foi analisada a calçada que se estende em frente ao Edifício Plaza Centenário, justamente por estar mais próxima à Estação Berrini.

O percurso selecionado possui uma característica peculiar: a existência da uma avenida de trânsito rápido, que acaba condicionando inúmeras características físicas e ergonômicas do espaço. Uma vez que o limite de velocidade da pista local da Av. Marginal Pinheiros é de $70 \mathrm{~km} / \mathrm{h}$ e o da pista expressa é $90 \mathrm{~km} / \mathrm{h}$, infraestruturas para ciclistas, por exemplo, não existem na própria avenida. Apesar de não ser visível a partir do trecho, sabe-se, no entanto, que há uma ciclovia após a via expressa e a linha de trem, mais próxima ao rio. O caráter da via também resulta na ausência de estacionamentos nas pistas e de estacionamentos privados nos lotes adjacentes.
\end{abstract}

Como era de se esperar, o fluxo de veículos no trecho é muito grande. A partir da medição feita às $10 \mathrm{~h}$, calculou-se que passam 6.780 veículos em uma hora só na pista local da Marginal Pinheiros, que é a mais próxima à calçada analisada. Na contagem das $12 \mathrm{~h}$, o número obtido foi 5.520 e na das $15 \mathrm{~h}$, aumentou para 6.060 veículos por hora. Apesar dessa diferença, pode-se dizer que esse fluxo é intenso e constante, causando certo desconforto nos pedestres, em razão do ruído do trânsito, da qualidade do ar e do perigo que a alta velocidade dos automóveis oferece.

O fluxo de pedestres, em contrapartida, não se destaca demasiadamente. Nas medições feitas às $10 \mathrm{~h}, 12 \mathrm{~h}$ e $15 \mathrm{~h}$, calculou-se que passam, no trecho, 852, 1.356 e 756 pedestres/ hora, respectivamente. Muitos deles se direcionam ao edifício comercial Plaza Centenário, que constitui o único tipo de uso do solo do percurso. A maioria, no entanto, utiliza a calçada do trecho como caminho para outras áreas e prédios do bairro. Como pode-se observar, o resultado da medição intermediária é maior se comparado aos restantes, o que pode ser justificado pelo deslocamento que muitos que trabalham na região fazem 
na hora do almoço, a fim de encontrar um lugar para se alimentar.

Uma característica positiva do trecho é a proximidade aos meios de transporte coletivos: distancia-se menos de $50 \mathrm{~m}$ da Estação Berrini da CPTM e menos de $100 \mathrm{~m}$ do ponto de ônibus da Av. Marginal Pinheiros (o mesmo comentado no trecho 1). Em relação aos atrativos verdes, há uma presença relativamente boa de vegetação, principalmente nos jardins dos lotes e no canteiro central da Marginal. Isso sem falar nas árvores e plantas distribuídas ao longo da calçada, algumas vezes em canteiros, outras em vasos.

Em geral, a calçada do trecho é boa no que tange à largura e quantidade de obstáculos, se comparada às outras. Apesar de apresentar bocas de lobo, alguns acessos à garagens, árvores e canteiros de plantas, postes e placas de sinalização, esses obstáculos estão alinhados, e a largura de 3,05m da calçada parece ser suficiente para o passeio. O acabamento do piso, a inclinação da calçada e a altura das guias também se mostraram corretas. O único porém foi a altura das árvores: uma vez que algumas ainda estão em fase de crescimento, suas copas às vezes obrigam o pedestre a desviar alguns centímetros o seu caminho.
Figuras 64-66: Calçada da pista local da Av. Marginal Pinheiros, em frente ao Edifício Plaza Centenário (Trecho 2). Fonte: Acervo LABAUT.
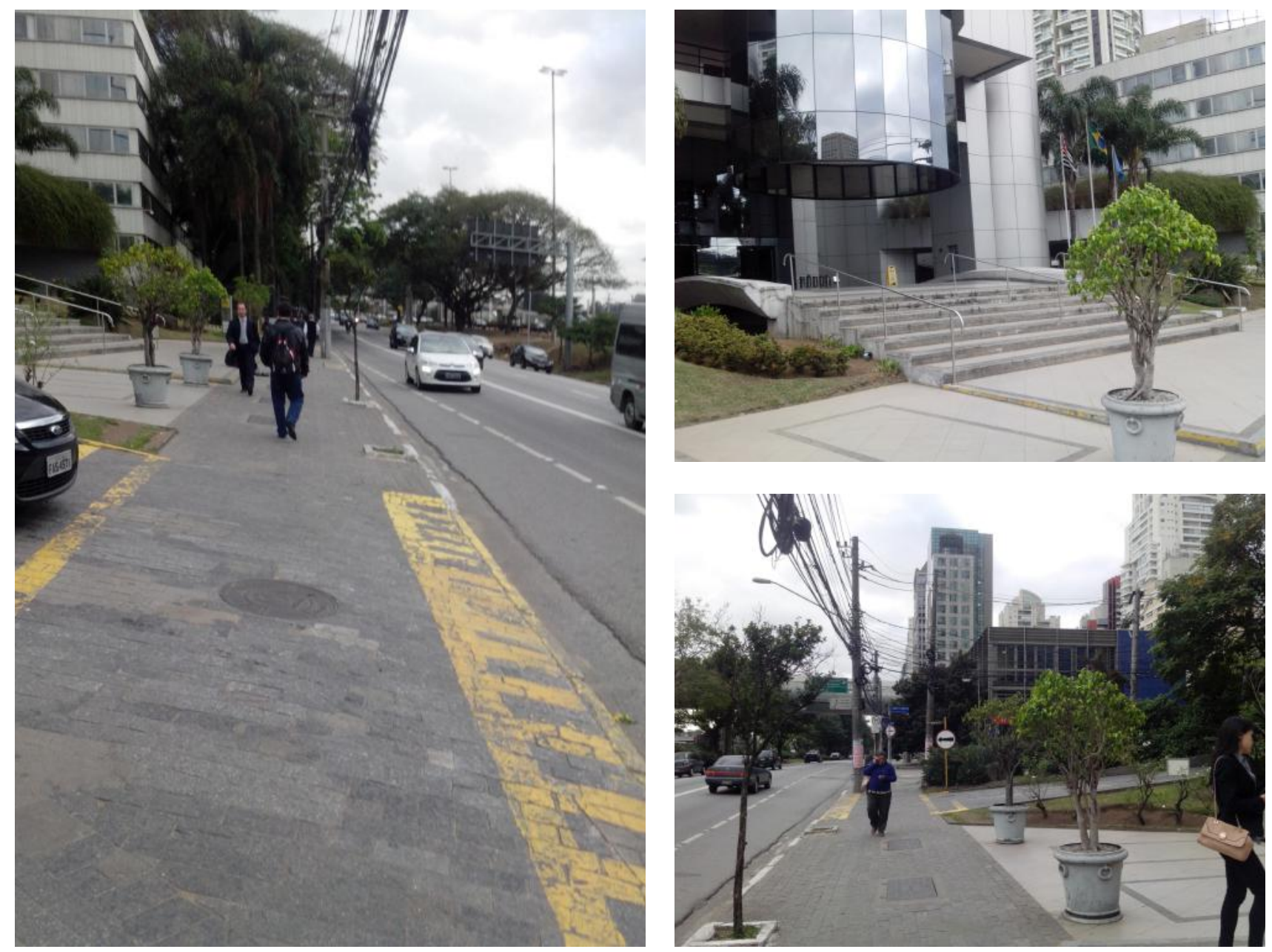


\section{ESTAÇÃO BERRINI DA CPTM}

Trecho 2: Calçada da pista local da Av. Marginal Pinheiros, em frente ao Edifício Plaza Centenário

Presença de infraestrutura ao cicilista

Ausência de estacionamentos

Há apenas o uso comercial no local

Há presença de vegetação na área

O trecho está a menos de $50 \mathrm{~m}$ da estação de trem e a $100 \mathrm{~m}$ do ponto de ônibus mais próximo

O limite de velocidade da pista local da Av. Marginal Pinheiros é de $70 \mathrm{~km} / \mathrm{h}$

Com 3,05m de largura, a calçada mostra-se suficiente para o fluxo de pedestres

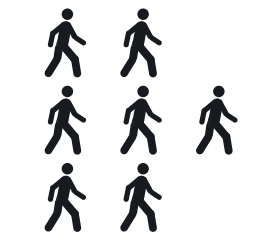

10h: 6780 veículos/hora

12h: 5520 veículos/hora

15h: 6060 veículos por hora

Obstáculos presentes na calçada

10h: 850 pedestres/hora

12h: 1356 pedestres/hora

15h: 756 pedestres/hora
Bocas de lobo, acessos à garagens, raízes e copas de árvores, canteiros de plantas, postes e placas de sinalização

Acabamento do piso, declividade da calçada e altura das guias adequados. Altura das árvores inadequada
Adequação dos obstáculos

Tabela 44: Tabela síntese dos questionários aplicados no Trecho 2 da Estação Berrini. Fonte: Elaborado pela autora. 


\title{
Trecho 3: Calçadas da R. Joel Carlos Borges, entre os $N^{\circ} 60$ e 92
}

\begin{abstract}
$A^{\prime}$ rua em questão foi selecionada justamente por ser um ponto de destino e de origem do restante do fluxo de pedestres que sai ou entra na Estação Berrini da CPTM, de modo que se deu preferência para o trecho entre as casas no 60 e 92 porque era o local mais movimentado ao longo da via. Diferentemente dos trechos 1 e 2, o espaço tem, além da função de passagem, um caráter de permanência, principalmente no horário do almoço: às 10h, contou-se que passam 1.212 pedestres/hora no percurso. Às 12h, o horário de almoço, esse número duplicou: 2.676 pedestres por hora. Às 15h, o número voltou para 1.272 pedestres/h. Essa maior atratividade do local no horário de almoço pode ser justificada pela existência, além de edifício empresariais e residenciais, de estabelecimentos comerciais voltados ao ramo alimentício, como bares e restaurantes.
\end{abstract}

Para a quantidade de pessoas que caminham ou permanecem no ambiente, a largura das calçadas é inadequada: apresentam $2,17 \mathrm{~m}$ de um lado e $1,68 \mathrm{~m}$ do outro. Apesar do acabamento do piso ser razoável, da inclinação das calçadas e a altura das guias e das árvores serem corretas, nesses pequenos espaços ainda se encontram obstáculos como saliências e degraus, acessos às garagens, raízes de árvores, canteiros de plantas, vigilantes, lixos e dejetos, postes e placas de sinalização. Isso sem falar nas próprias pessoas que estão no local e funcionam como obstáculos móveis. Destarte, os pedestres encontram muita dificuldade para andar no trecho, frequentemente tendo que desviar seu caminho para a rua.

Em contrapartida, como as medições do trecho 1 indicam, o fluxo de veículos ao longo da R. Joel Carlos Borges é baixo. Neste caso, a partir da medição das $10 \mathrm{~h}$, passam 72 veículos/hora no local. Nas medições das $12 \mathrm{~h}$ e $15 \mathrm{~h}$, os números obtidos foram iguais: passam 60 veículos/hora no trajeto. Se somar esse fluxo com o baixo limite de velocidade, que é $30 \mathrm{~km} / \mathrm{h}$, a via apresenta caráter de uma rua pedonal.

No espaço não há nenhuma infraestrutura ao ciclista, e os veículos ainda podem estacionar nos dois lados da via. Essa característica só muda com a aproximação da Estação Berrini da CPTM, onde só pode estacionar em um lado da via. Os atrativos verdes na área são constantes e regulares, localizados nos jardins dos 
Figuras 67-72: Calçadas da R. Joel Carlos Borges, entre os $N^{\circ} 60$ e 92 (Trecho 3). Fonte: Acervo LABAUT. lotes e em alguns canteiros de plantas ao longo do trajeto. Por fim, a proximidade aos meios de transporte coletivo é evidente: distancia-se menos de $50 \mathrm{~m}$ da estação de trem e quase $100 \mathrm{~m}$ do ponto de ônibus mais próximo.
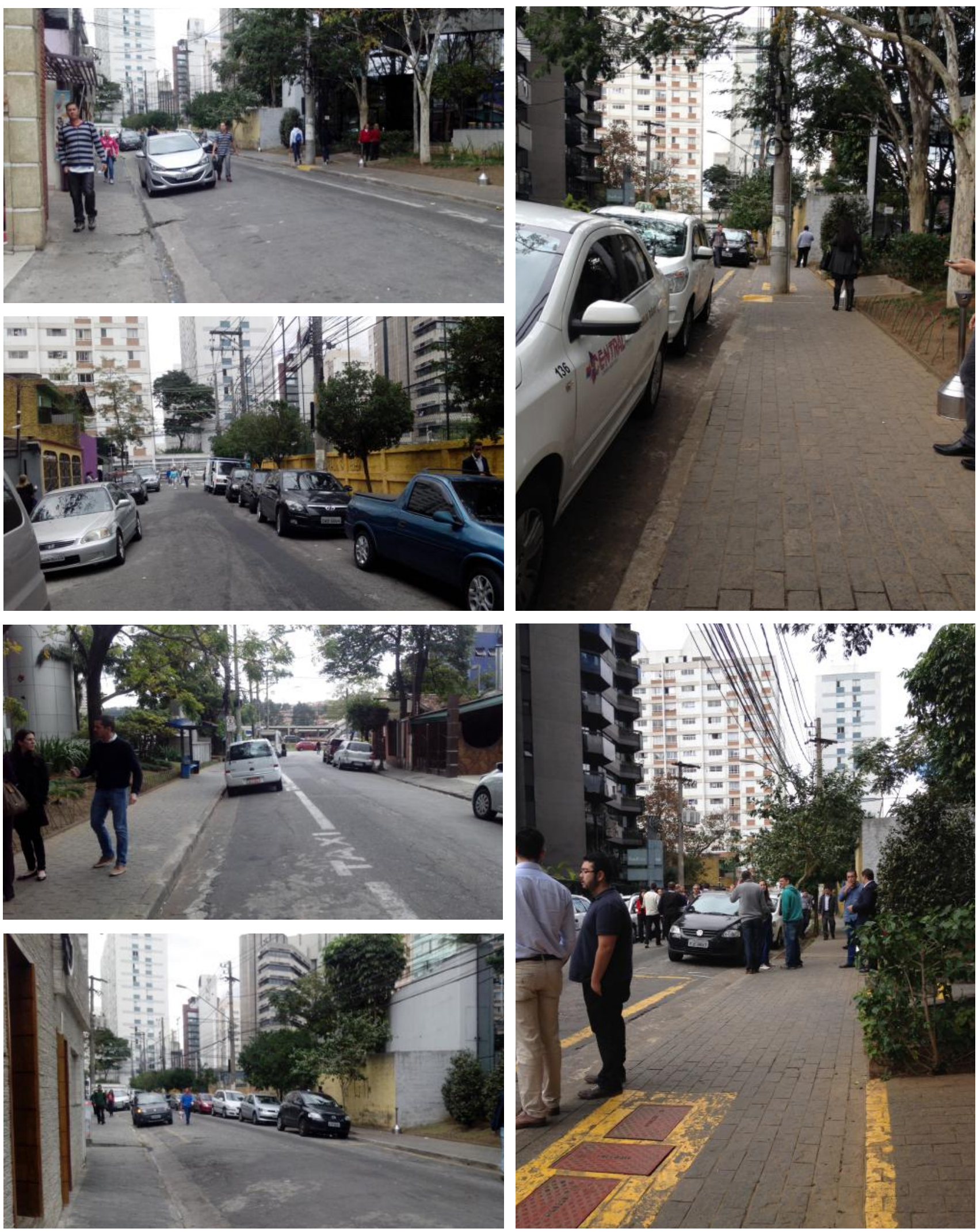

150 Capítulo 6: Aplicação do método de avaliação ergômica do ambiente urbano 


\section{ESTAÇÃO BERRINI DA CPTM}

Tusecho 3: Calçadas da R. Joel Carlos Borges, entre os $\mathrm{N}^{\circ} 60$ e 92
Os veículos podem estacionar nos dois lados da via
Há pelo menos dois uso de solo no trecho: comercial e
residencial

Tabela 45: Tabela síntese dos questionários aplicados no Trecho 3 da Estação Berrini. Fonte: Elaborado pela autora. 


\section{Entorno da Estação Vila Olímpia da CPTM}

Figura 73: Estação Vila Olímpia da CPTM e área levantada no EMBARQ Brasil. Fonte: Elaborado por Gabriel Novaes. ssim como na Estação Berrini, foram escolhidos três trechos para avaliação, de modo a analisar diferentes elementos urbanos e como eles podem influenciar a percepção e o conforto do pedestre. O primeiro trecho escolhido foi a saída da estação Vila Olímpia mais próxima à R. Beira Rio. O segundo trecho foi a outra saída do estabelecimento, do lado da Av. Marginal Pinheiros. O terceiro trecho, um pouco mais distante, foi a R. Funchal, próximo do seu encontro com a R. Gomes de Carvalho. As medições seguiram o horário padrão anteriormente estabelecido: ocorreram às $10 \mathrm{~h}, 12 \mathrm{~h}$ e $15 \mathrm{~h}$, para cada trecho selecionado.
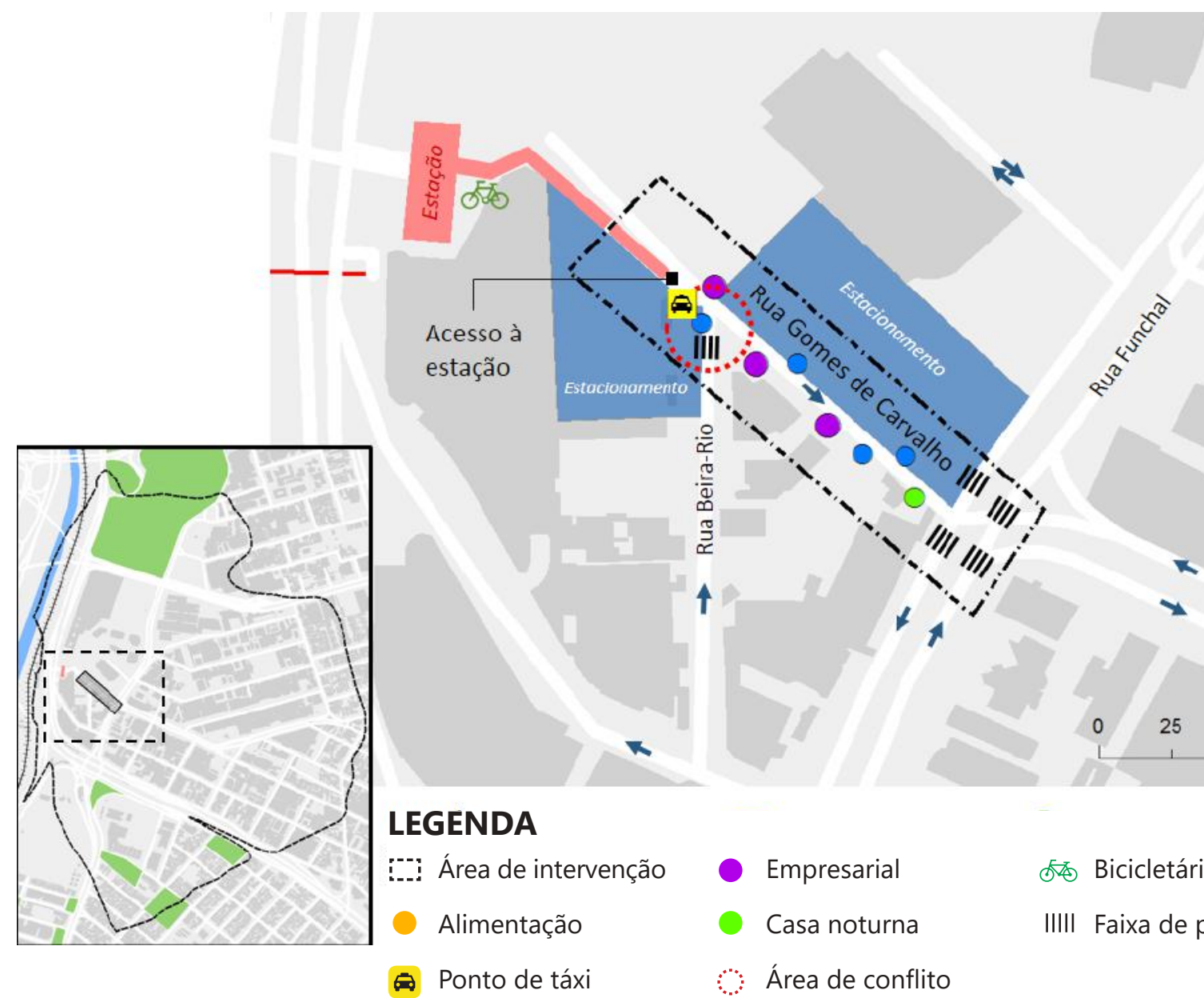

\section{LEGENDA}

Área de intervenção

Alimentação

Ponto de táxi
- Empresarial

Casa noturna

Área de conflito 


\title{
Trecho 1: Saída da Estação Vila Olímpia, do lado da R. Beira Rio
}

\begin{abstract}
$A^{p}$ pesar do trecho selecionado se restringir fisicamente à calçada imediata da saída da estação, o entorno, marcado pelo cruzamento da R. Beira Rio com a R. Gomes de Carvalho, também foi atentamente observado, uma vez que caracteriza fortemente o local. Cercado por usos comerciais e de serviços, representados nos edifícios empresariais e na própria estação de trem, o espaço sofre grande influência do fluxo de pedestres. Na medição das $10 \mathrm{~h}$, contou-se que passam no trecho 5.900 pedestres/hora. Já às 12h, esse número reduziu para 2.080 pedestres/h e em seguida, às 15h, diminui novamente: em uma hora passaram 1.640 pessoas no local. O número elevado obtido na primeira medição decorre do início de expediente de trabalho, o que pode ser comprovado pelo sentido predominante do fluxo dos pedestres: a R. Funchal, onde se localiza um importante centro comercial.

É interessante observar que a calçada da saída da Estação Vila Olímpia serve apenas como extensão da última. As pessoas da área que não utilizam o trem não passam por ela, o que reflete na largura do passeio: apesar de apresentar $7,75 \mathrm{~m}$ em seu eixo central, nas laterais diminui para $1,50 \mathrm{~m}$ de um lado e $1,90 \mathrm{~m}$ de outro, medidas insuficientes para o fluxo de pedestres. Em relação aos obstáculos existentes na calçada analisada, são aqueles vistos comumente no resto da cidade: lixeiras, ambulantes e suportes, vigilantes, lixos, postes e placas de sinalização. Destacam-se ainda um ponto de táxi em uma lateral da calçada e uma cabine de vigia do outro, ocupando praticamente toda a extensão do passeio. $O$ acabamento do piso, a inclinação da calçada e a altura das guias parece adequada.

A partir da medição das 10h, calculou-se que em uma hora, passam 156 veículos no cruzamento da R. Beira Rio com a R. Gomes de Carvalho. Às $12 \mathrm{~h}$, contou-se 144 veículos/h e na medição das 15h, o resultado foi 216 veículos/h. Como é possível notar, não há um fluxo grande de veículos na área, e aqueles que passam são táxis, motos e de funcionários dos edifícios comerciais do entorno. Ainda assim, dada a grande quantidade de pessoas na área, o movimento dos veículos é condicionado a intensidade do fluxo de pedestres. Dessa maneira, apesar do limite de $30 \mathrm{~km} / \mathrm{h}$ das ruas Beiras Rio e Gomes de Carvalho, os veículos são obrigados a permanecerem em uma velocidade de 10 a $20 \mathrm{~km} / \mathrm{h}$, para evitar o risco de atropelamento.
\end{abstract}


Figuras 74-79: Saída da Estação Vila Olímpia, do lado da R. Beira Rio (Trecho 1). Fonte: Acervo LABAUT.
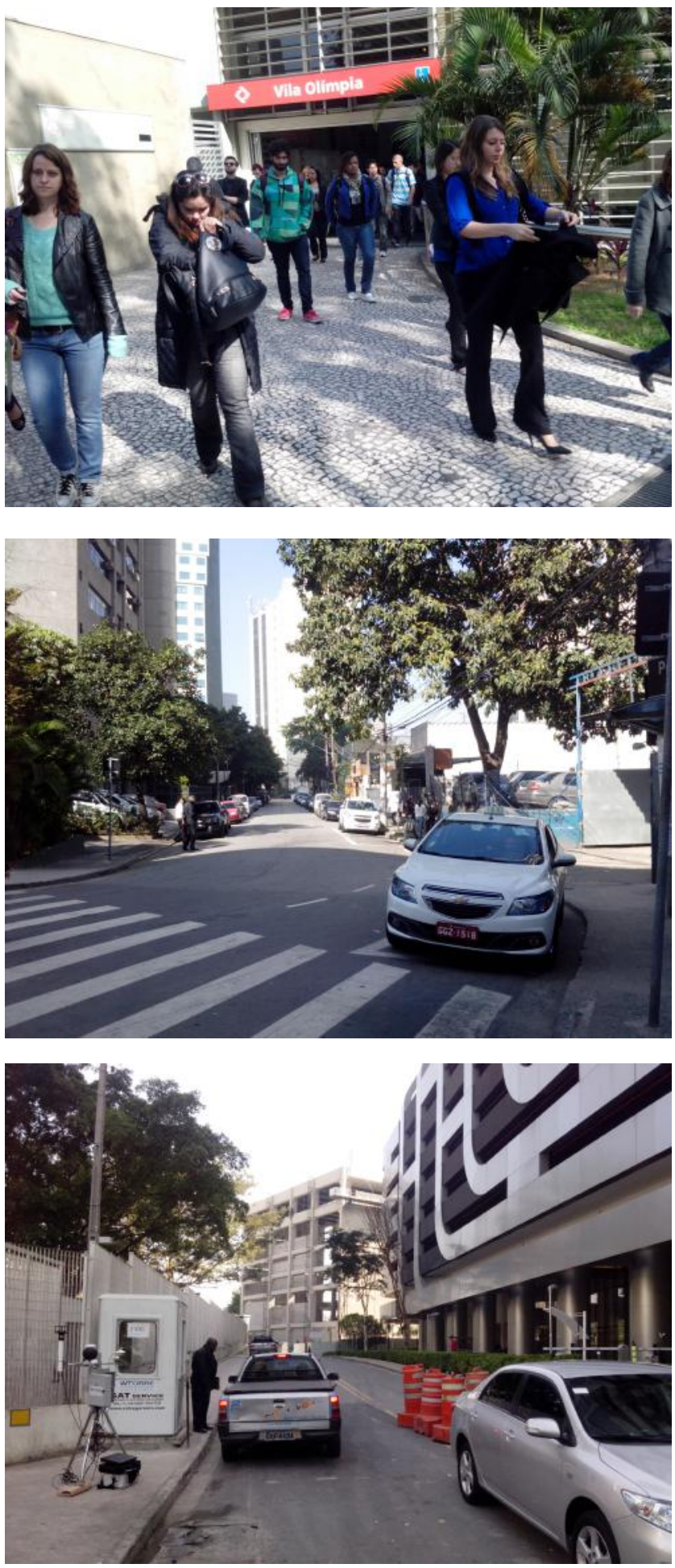

No trecho em questão, não há nenhuma infraestrutura ao ciclista. Não é permitido estacionar em nenhum lado da via próximo ao cruzamento da R. Beira Rio com a R. Gomes de Carvalho e há muitos estacionamentos privados na área. Em compensação, o percurso abrange a estação de trem e está distante $150 \mathrm{~m}$ do ponto de ônibus mais próximo. Embora não existam atrativos verdes na calçada da saída da Estação Vila Olímpia, são visíveis árvores e plantas nos jardins de edifícios e lotes ao redor do trecho.
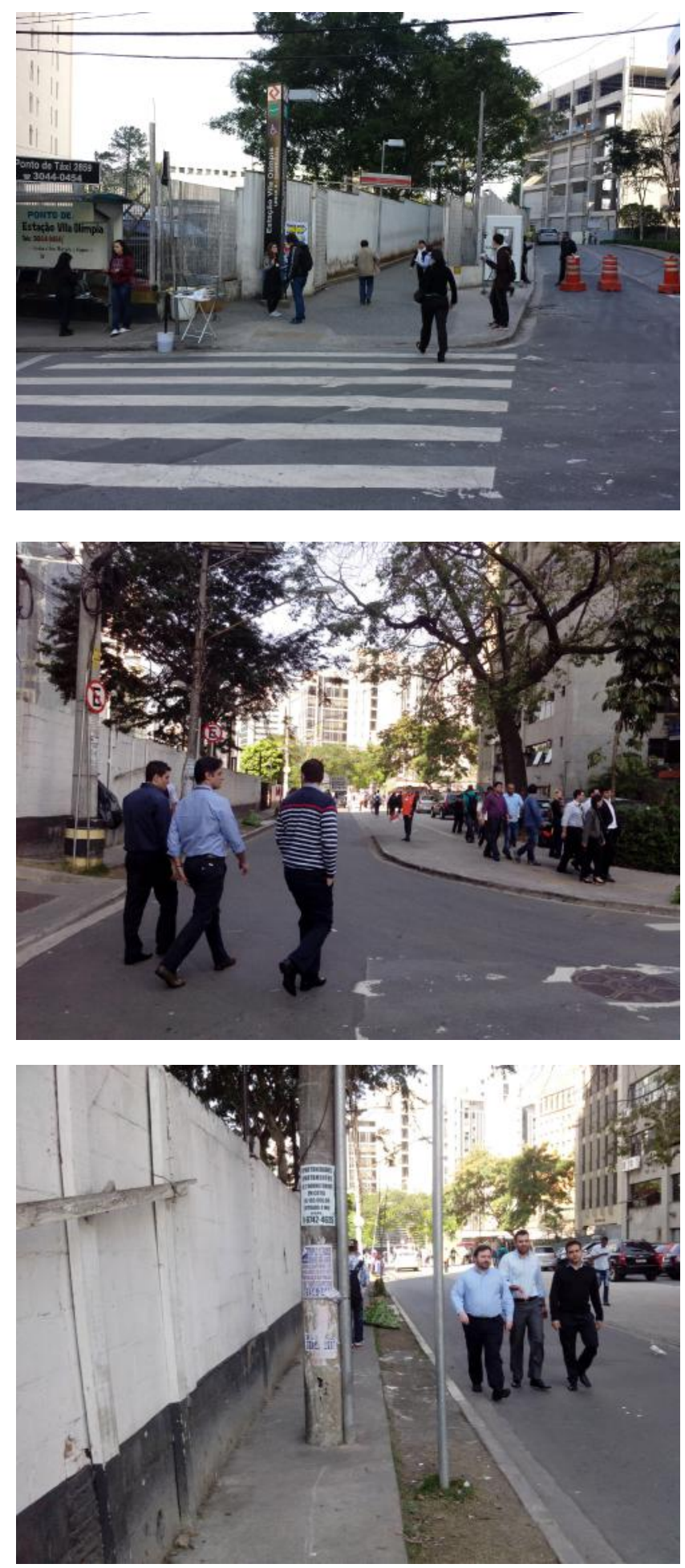

154 Capítulo 6: Aplicação do método de avaliação ergômica do ambiente urbano 


\section{ESTAÇÃO VILA OLÍMPIA DA CPTM}

Tusência de infraestrutura ao cicilista
Os veículos não podem estacionar em nenhum lado da via e há
estacionamentos privados na área
Há pelo menos dois uso de solo no trecho: comercial e
residencial

Tabela 46: Tabela síntese dos questionários aplicados no Trecho 1 da Estação Vila Olímpia. Fonte: Elaborado pela autora. 


\title{
Trecho 2: Saída da Estação Vila Olímpia, do lado da Av. Marginal Pinheiros
}

\begin{abstract}
A outra saída da Estação Vila Olímpia, que desemboca em uma calçada que tangencia a pista local da Av. Marginal Pinheiros, apresenta características diametralmente opostas em relação à saída da R. Beira Rio, que foi representada no trecho 1. Sendo assim, pareceu-nos interessante análisá-la, justamente pela possível comparação entre esses dois trajetos que, embora surjam de um mesmo estabelecimento, apresentam sensações completamente distintas. No segundo trecho, avaliou-se a calçada que se estende em frente à saída da estação.
\end{abstract}

Apesar de não ser vista a partir do percurso selecionado, sabe-se que existe uma ciclovia entre o Rio Pinheiros e a pista expressa da Av. Marginal Pinheiros, que é um importante elemento de infraestrutura ao ciclista, e pode ser acessada pela própria Estação Vila Olímpia. Outro aspecto positivo da região é a proximidade com o transporte coletivo: além de abranger a estação de trem, o trecho distancia -se menos de $100 \mathrm{~m}$ do ponto de ônibus mais próximo, que está localizado na Av. Marginal Pinheiros.

O uso do solo constitui um aspecto negativo do ambiente: no trecho, só há acesso para um uso de serviço, que é a própria estação de trem. Uma vez que a Marginal é intransponível no térreo e que no outro lado da via não há nenhum estabelecimento, a região fica um pouco deserta para pedestres. Na contagem do fluxo de pessoas, essa característica é evidente: a partir das medições às $10 \mathrm{~h}, 12 \mathrm{~h}$ e $15 \mathrm{~h}$, calcula -se que passam 984, 528 e 708 pedestres/h no local, respectivamente.

Em relação à calçada, ao levar em conta a quantidade de pessoas na área, ela parece adequada: em toda sua extensão tem 3,40m de largura. Somente nos extremos laterais, depois da extensão do trecho, que a largura reduz para 3,05m de um lado e 2,30m para o outro. A calçada não possui tantos obstáculos: apresenta algumas saliências, acesso a uma garagem que atende a estação de trem, alguns canteiros de plantas, postes, placas de sinalização e bloqueios entre o passeio livre e a Av. Marginal. Mesmo assim, esses obstáculos estão alinhados, permitindo um espaço de caminhada constante. A declividade da calçada, a altura das guias e a altura das árvores está correta, e o único porém é o acabamento do piso, que mostra -se inadequado.

Permitindo uma velocidade de até $70 \mathrm{~km} / \mathrm{h}$ na pista local e até 
$90 \mathrm{~km} / \mathrm{h}$ na expressa, a Av. Marginal Pinheiros destaca-se pela grande quantidade de veículos que a percorrem, que constituem um fluxo alto e constante durante o dia. A partir da medição feita às $10 \mathrm{~h}$, estipulou-se que passam 5.760 veículos/h só na pista local. Na medição das $12 \mathrm{~h}$, foram contados 5.880 veículos em uma hora. Às $15 \mathrm{~h}$, contou -se 5.340 veículos por hora. Devido justamente ao caráter da via de trânsito rápido, é proibido estacionar ao longo da avenida. Apesar de existirem vegetações nos canteiros da saída da Estação Vila Olímpia e no canteiro central da Av. Marginal Pinheiros, eles não são suficientes para minimizar o ruído e a qualidade do ar no espaço.
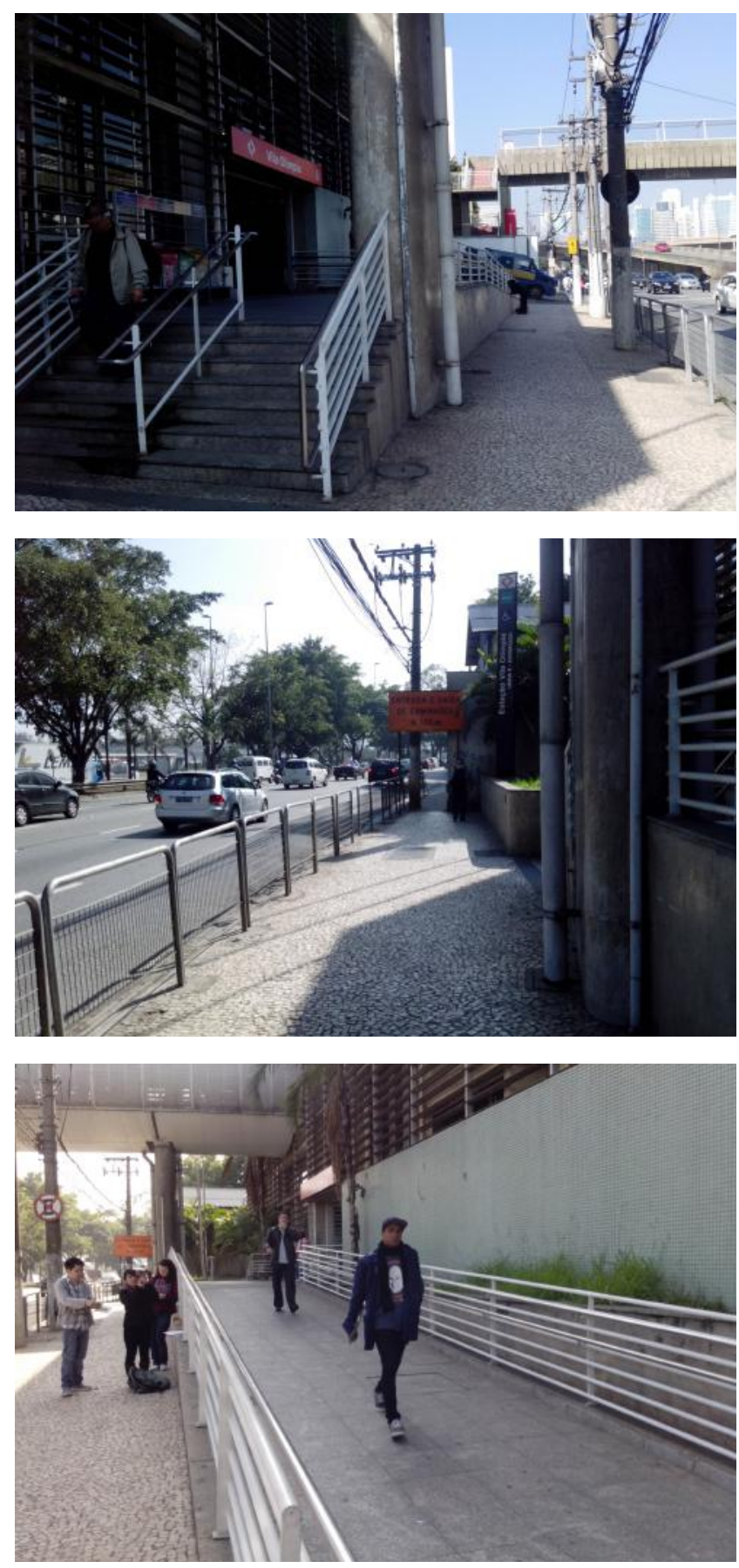

Figuras 80-85: Saída da

Estação Vila Olímpia, do lado da Av. Marginal Pinheiros (Trecho 2). Fonte: Acervo LABAUT.
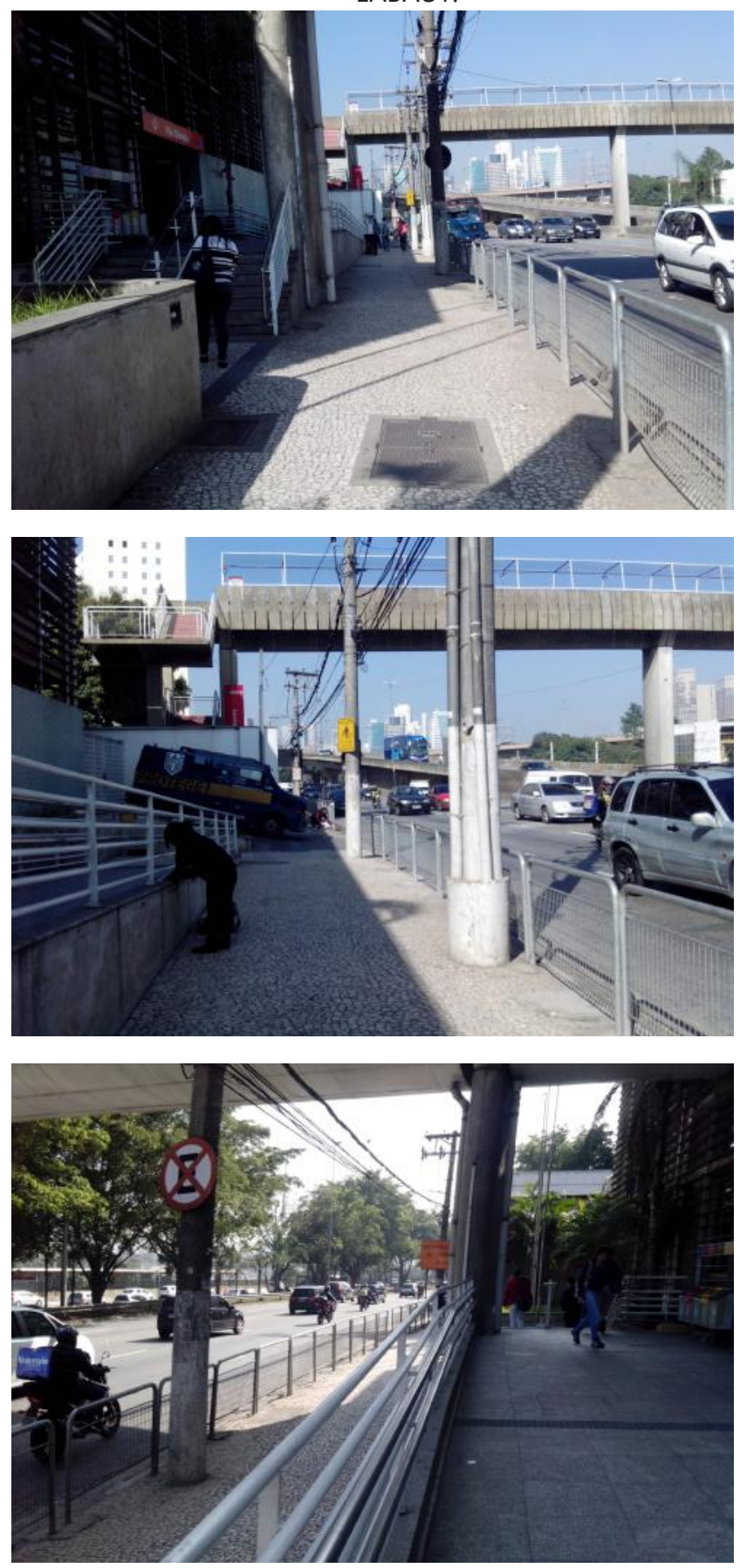


\section{ESTAÇÃO VILA OLÍMPIA DA CPTM}

Presença de infraestrutura ao cicilista
Os veículos não podem estacionar em nenhum lado da via

Tabela 47: Tabela síntese dos questionários aplicados no Trecho 2 da Estação Vila Olímpia. Fonte: Elaborado pela autora. 


\section{Trecho 3: Calçadas da R. Funchal próximas à \\ R. Gomes de Carvalho}

nserida em um centro empresarial muito movimentado, marcado por edifícios comerciais e de serviços, a R. Funchal foi selecionada por ser um pólo de atração da metrópole paulistana, com função tanto de passagem como de destino. O trecho escolhido abrange justamente sua intersecção com a R. Gomes de Carvalho, que é onde desemboca a grande maioria das pessoas que saem da Estação Vila Olímpia da CPTM.

Diferentemente dos outros trechos analisados, este apresenta uma ciclorrota, que indica a possibilidade de haver ciclistas na região. A ciclorrota localiza-se na R. Funchal, nos dois sentidos da via, e continua da R. Gomes de Carvalho, no sentido oposto ao da Estação Vila Olímpia, e funciona de domingo, das $7 \mathrm{~h}-16 \mathrm{~h}$. Como o limite de velocidade da R. Funchal é de $60 \mathrm{~km} / \mathrm{h}$, não é permitido estacionar na mesma. No entanto, há diversos estacionamentos privados na área.

O trecho em questão permanece próximo aos meios de transporte coletivo: está a cerca de $150 \mathrm{~m}$ da estação de trem e a $50 \mathrm{~m}$ do ponto de ônibus mais próximo, localizado na R. Funchal. A vegetação ao longo do percurso é razoável, ela não inexiste, mas também não é abundante. Plantas e árvores são principalmente identificados no canteiro central da R. Funchal, nas calçadas e nos lotes adjacentes a elas.

$\mathrm{Na}$ medição realizada às 10h, contou-se que passam 2.364 pedestres no trecho, em uma hora. Às $12 \mathrm{~h}$, foram contabilizados 3.192 pedestres/h. E às 15h, o número diminui para 2.292 pedestres por hora. Ao considerar somente a dimensão das calçadas da R. Funchal, a primeira impressão é de que são largas: têm 4,10m de um lado e 3,22m do outro. No entanto, ao compará-las com o fluxo de pedestres no local, elas mostram-se insuficientes, principalmente no horário do almoço, no qual podemos notar um maior movimento das pessoas que trabalham na região. Os obstáculos presentes nas calçadas dificultam ainda mais o caminho do pedestre. Nelas, é possível identificar buracos e depressões, bocas de lobo, acessos a garagens, raízes e copas de árvores, canteiros de plantas, lixeiras, ambulantes, lixos e dejetos, hidrantes, postes e placas de sinalização. A altura das guias e das árvores mostra-se correta, mas o acabamento do piso e a inclinação da calçada em certos pontos são inadequados. 
Figuras 86-91: Calçadas da R. Funchal próximas à R. Gomes de Carvalho (Trecho 3). Fonte: Acervo LABAUT.

A partir da medição realizada às $10 \mathrm{~h}$, contou-se que passam 2.568 veículos/h só em um sentido da R. Funchal (aquele mais próximo da Estação Vila Olímpia). Às $12 \mathrm{~h}$, o número contado foi 2.748 veículos/h e na medição das $15 \mathrm{~h}$, o resultado foi de 2.820 veículos por hora. Nesse contexto, o pedestre se sente desconfortável na calçada, ao mesmo tempo que se sente acuado pelo intenso fluxo de veículos no local.
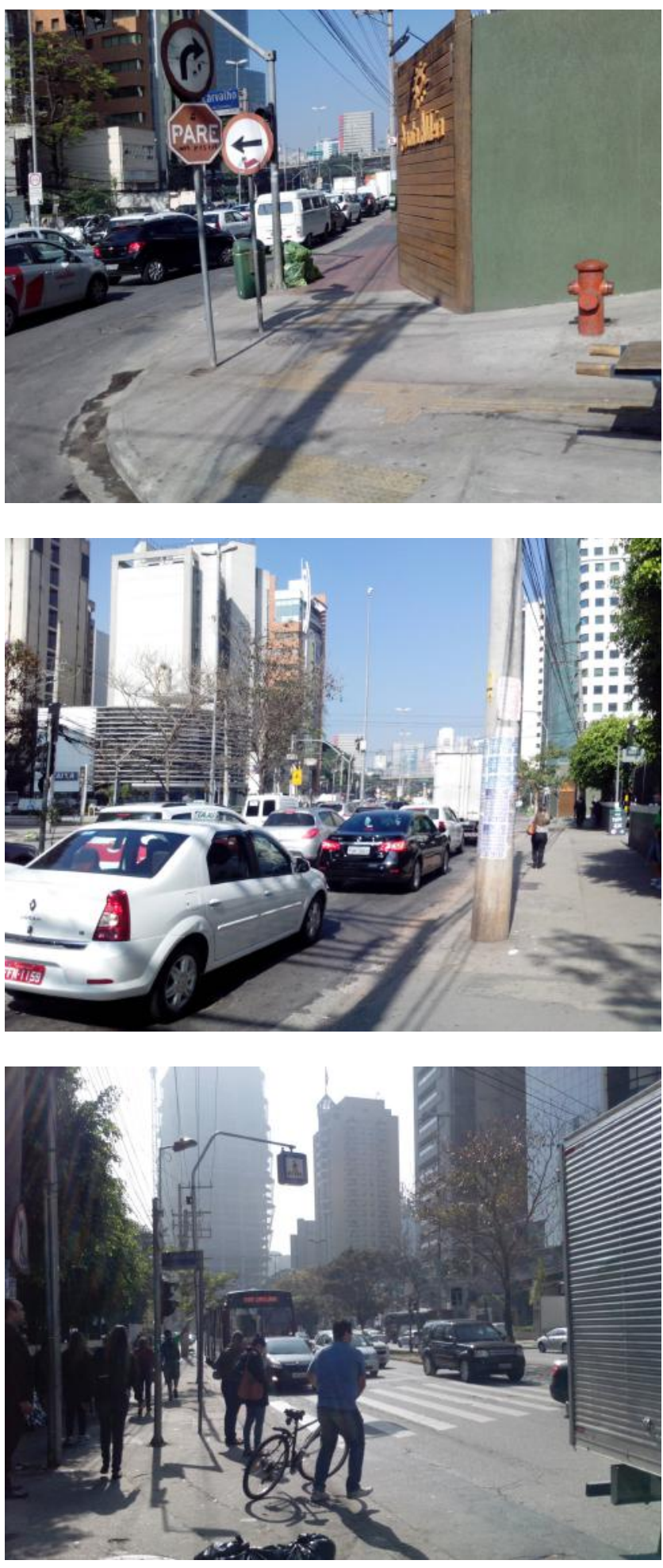
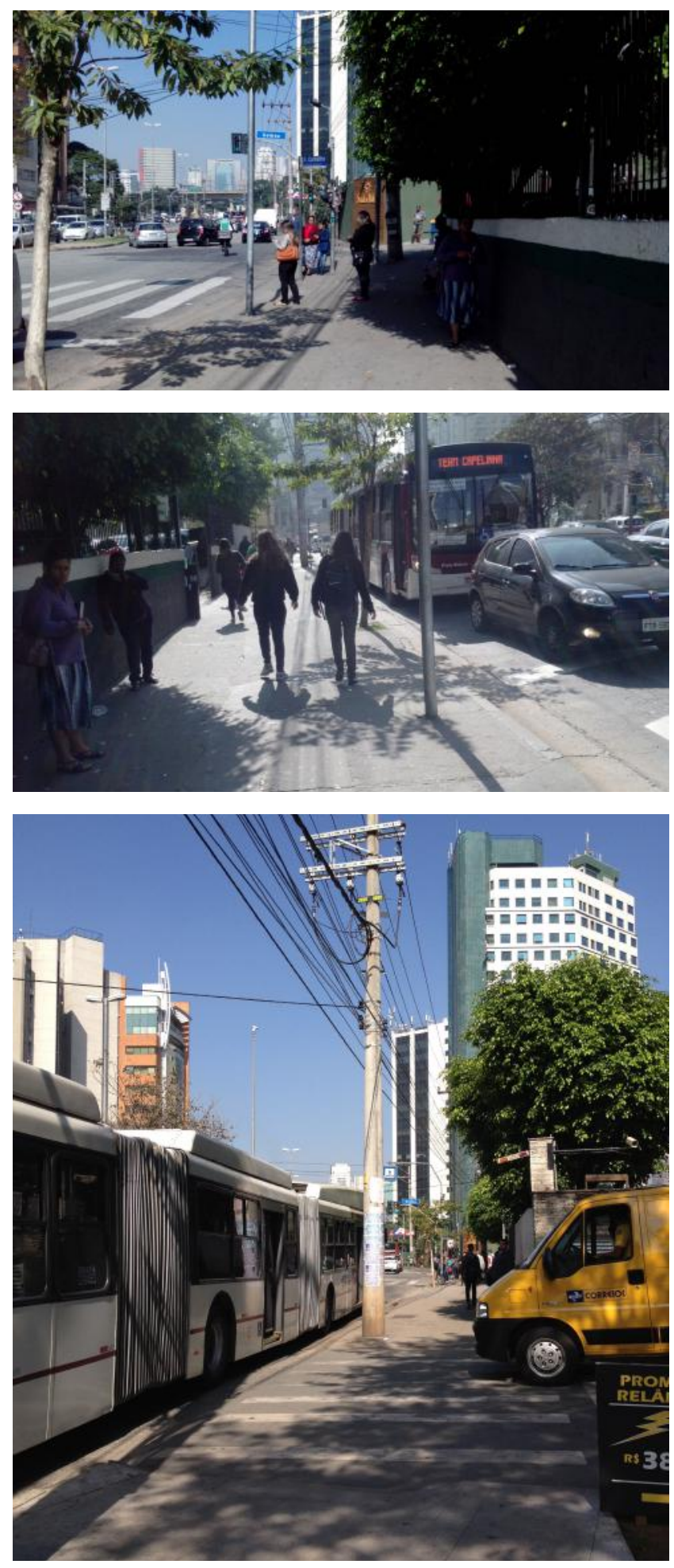


\section{ESTAÇÃO VILA OLÍMPIA DA CPTM}

Trecho 3: Calçadas da R. Funchal próximas à R. Gomes de Carvalho

\begin{tabular}{|c|c|}
\hline & $\begin{array}{l}\text { Presença de ciclorrota na R. Funchal e na R. Gomes de Carvalho, } \\
\text { que funciona de domingo, das } 7 \mathrm{~h}-16 \mathrm{~h}\end{array}$ \\
\hline & $\begin{array}{l}\text { Os veículos não podem estacionar na via. Há estacionamentos } \\
\text { privados na região }\end{array}$ \\
\hline & $\begin{array}{l}\text { Há pelo menos dois tipos de uso de solo: comercial e de } \\
\text { serviços }\end{array}$ \\
\hline & Há presença de vegetação na área \\
\hline & $\begin{array}{l}\text { O trecho distancia-se } 150 \mathrm{~m} \text { da estação de trem e a } 50 \mathrm{~m} \text { do } \\
\text { ponto de ônibus mais próximo }\end{array}$ \\
\hline & O limite de velocidade da R. Funchal é de $60 \mathrm{~km} / \mathrm{h}$ \\
\hline & $\begin{array}{l}\text { Apesar das calçadas da R. Funchal terem } 4,10 \mathrm{~m} \text { e } 3,22 \mathrm{~m} \text { de largura, } \\
\text { mostram-se insuficientes para o fluxo de pedestres }\end{array}$ \\
\hline$\dot{\alpha} \dot{\alpha} \dot{\alpha} \dot{\alpha}$ & 10h: 2364 pedestres/hora \\
\hline$\dot{\alpha} \dot{\alpha} \dot{\alpha}$ & 12h: 3192 pedestres/hora \\
\hline 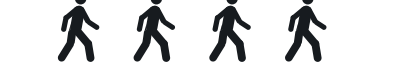 & 15h: 2292 pedestres/hora \\
\hline مים & 10h: 2568 veículos/hora \\
\hline ه内 & 12h: 2748 veículos/hora \\
\hline ه & 15h: 2820 veículos por hora \\
\hline $\begin{array}{l}\text { Obstáculos } \\
\text { presentes na calçada }\end{array}$ & $\begin{array}{l}\text { Saliências e degraus, acesso à garagem, canteiros de plantas, } \\
\text { bloqueios, postes e placas de sinalização }\end{array}$ \\
\hline $\begin{array}{l}\text { Adequação dos } \\
\text { obstáculos }\end{array}$ & $\begin{array}{l}\text { Declividade da calçada, altura das guias, altura das árvores ade- } \\
\text { quados. Acabamento do piso inadequado }\end{array}$ \\
\hline
\end{tabular}

Tabela 48: Tabela síntese dos questionários aplicados no Trecho 3 da Estação Vila Olímpia. Fonte: Elaborado pela autora. 


\section{Entorno da Estação Santo Amaro da CPTM}

Figura 92: Estação Santo Amaro da CPTM e área levantada no EMBARQ Brasil. Fonte: Elaborado por Gabriel
Dara otimizar as avaliações e obter resultados coerentes com as diversas situações urbanas experimentadas no local, escolheuse três trechos para analisar. O primeiro foi a saída da Estação Santo Amaro, do lado da Av. Pe. José Maria. O segundo trecho foi a própria Av. Pe. José Maria, na calçada oposta à estação de trem. E o último foi a R. Engenheiro Francisco Pitta Brito, entre as construções de $\mathrm{N}^{\circ} 255$ até 425 . Novamente os horários estipulados para cada bateria de medições foram às $10 \mathrm{~h}, 12 \mathrm{~h}$ e $15 \mathrm{~h}$, para que a comparação com os outros dias de levantamento fosse mais precisa.

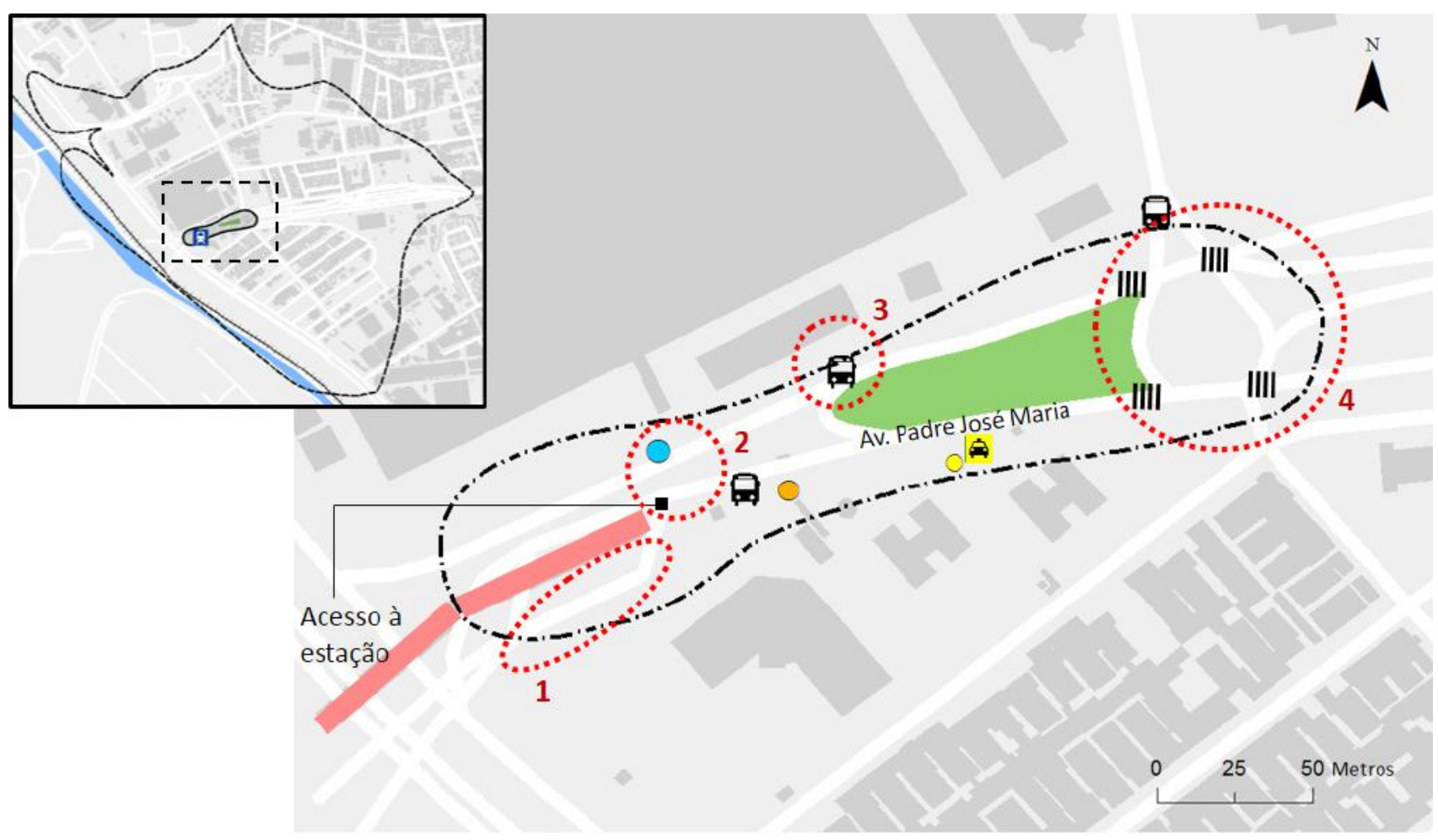

\section{LEGENDA}

:--: Área de intervenção

Banca de revista

6. Ponto de táxi
Residência

Transporte fretado

Ponto de ônibus
Área de conflito

IIIII Faixa de pedestre 


\section{Trecho 1: Saída da Estação Santo Amaro, do lado da Av. Pe. José Maria}

$\mathrm{D}$ iferentemente das outras estações de trem anteriormente analisadas, a de Santo Amaro desemboca no meio da calçada, que por sua vez se estende ao longo de toda a Av. Pe. José Maria. Nesse caso, portanto, houve a necessidade de estabelecer um limite dentro desse espaço, a fim de que a avaliação fosse mais específica. Sendo assim, definiu-se que o trecho em questão abrange a saída da estação e os $20 \mathrm{~m}$ seguintes da mesma calçada, que incluem no extremo uma banca de jornal.

Além da banca de jornal, o percurso apresenta obstáculos como buracos e depressões, bocas de lobo, raízes e copas de árvores, orelhões, ponto de ônibus, ambulantes, lixos e dejetos, postes e placas de sinalização. A inclinação da calçada e a altura das guias estão corretas, mas o acabamento do piso e a altura das árvores mostram-se inadequados para o passeio do pedestre. Apesar de todos esses elementos, a largura da calçada consegue minimizar a situação: possui 14,1 m. Essa largura varia um pouco ao longo do trecho, mas em geral reserva um espaço suficientemente grande para as pessoas que atravessam o local. Em relação ao canteiro central ao lado do trecho, por onde passam diversos pedestres, a largura é mais regular: $2,20 \mathrm{~m}$.

O fluxo de pedestres é relativamente alto no período da manhã e vai diminuindo no decorrer do dia, como pode- se verificar nas contagens das pessoas que saíam e entravam da estação de trem. Na medição das 10h, contou-se que por ali passam 1.284 pedestres por hora. Às 12h, o resultado diminui para 816 pedestres/h e às $15 \mathrm{~h}$ esse número se manteve. Em relação ao fluxo de veículos, ele é baixo, mas praticamente constante. Contando os veículos que percorriam os dois lados da Av. Pe. José Maria próximos ao trecho 2 , teve-se que, na medição das $10 \mathrm{~h}$ e $12 \mathrm{~h}$, passavam 456 veículos por hora. Às 15h, estipulou-se que passaram 526 veículos em uma hora.

Não há ciclovias ou qualquer outro tipo de infraestrutura ao ciclista no trecho. Por ser próximo à estação de trem, não é permitido estacionar no local, em nenhum lado da via, de modo que só é prevista uma área de embarque e desembarque para os ônibus, fretados e automóveis que percorrem o trajeto. Dado esse tipo de movimento, a velocidade permitida da via Pe. José Maria, que tangencia a Estação Santo Amaro, é de até $40 \mathrm{~km} / \mathrm{h}$. 
Figuras 93-96: Saída da Estação Santo Amaro, do lado da Av. Pe. José Maria (Trecho 1). Fonte: Acervo LABAUT.
A vegetação no ambiente é regular: encontra-se principalmente nos lotes vizinhos, em vasos espalhados ao longo da calçada e no canteiro central da avenida adjacente ao trecho. Há um grande incentivo do uso de transporte coletivo no espaço, uma vez que o percurso abrange a estação de trem e um ponto de ônibus. Em compensação, no trecho só se tem acesso a um estabelecimento de serviços, constituído pela própria Estação Santo Amaro.
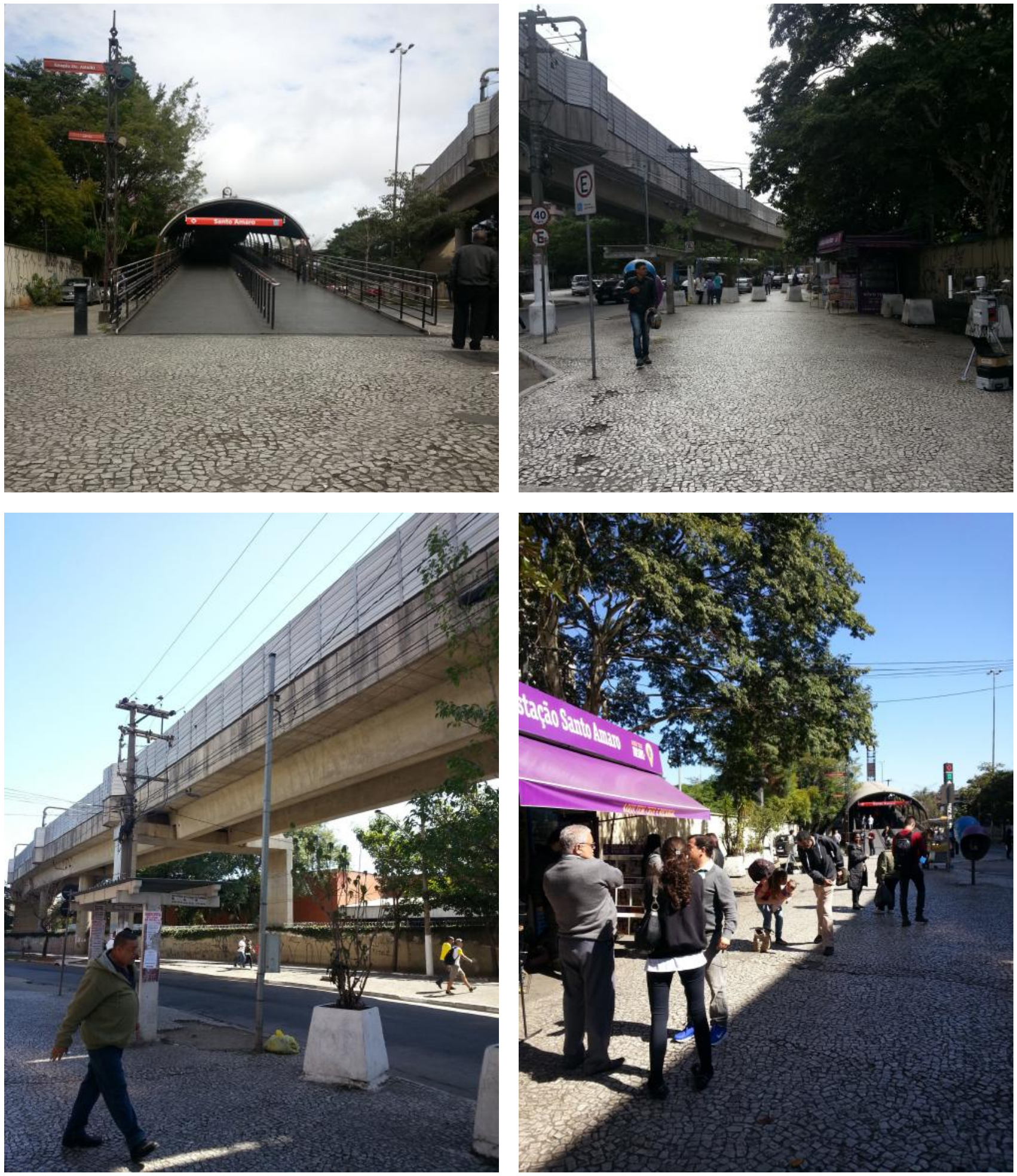

164 Capítulo 6: Aplicação do método de avaliação ergômica do ambiente urbano 


\section{ESTAÇÃO VILA SANTO AMARO DA CPTM}

Ausência de infraestrutura ao cicilista
Ausência de estacionamentos. Só é prevista uma área de
embarque e desembarque

Tabela 49: Tabela síntese dos questionários aplicados no Trecho 1 da Estação Santo Amaro. Fonte: Elaborado pela autora. 


\section{Trecho 2: Av. Pe. José Maria, na calçada oposta à Estação Santo Amaro}

$\mathrm{O}$ trecho em questão abrange a calçada oposta à Estação Santo Amaro da CPTM, na Av. Pe. José Maria. Como a via é relativamente extensa, tomou-se como referência o ponto de ônibus localizado na mesma calçada, situado a $60 \mathrm{~m}$ da estação de trem, e que atrai grande parte do fluxo de pedestres oriundos da última. O canteiro central da via também foi atentamente observado.

É possível notar que não há nenhuma infraestrutura ao ciclista no local. Mesmo havendo a Ciclovia Marginal Pinheiros perto, no trecho em questão ela não tem nenhuma espécie de continuidade. Essa situação, no entanto, é amenizada pela proximidade aos transportes coletivos, representados pelo próprio ponto de ônibus do trecho e pela sua proximidade com a estação de trem.

O fluxo de veículos na região não é muito relevante. Na medição realizada às $10 \mathrm{~h}$, contou-se que passam nos dois lados da Av. Pe. José Maria 576 veículos em uma hora. Às $12 \mathrm{~h}$, foram contabilizados 408 veículos/h e às 15h, foram 372 veículos por hora. Percebese, dessa maneira, um fluxo maior no período da manhã, mas que mantém uma constante no horário do almoço e no período da tarde. O limite de velocidade no local permanece $40 \mathrm{~km} / \mathrm{h}$ e, diferentemente do trecho 1 , neste os veículos podem estacionar de um lado da via.

O fluxo de pedestres segue o mesmo caminho, e não se destaca demasiadamente. Em todas as medições, contou-se os pedestres que vinham da direção do trem, no sentido do trecho escolhido, para abranger a maior quantidade de pessoas possível. O período da manhã continua sendo o mais movimentado, e o ápice do fluxo acontece no horário de almoço. Na medição das 10h, foram contabilizados 396 pedestres em uma hora. Às 12h, o número subiu para 420 pedestres/h. E às 15 h, o resultado obtido foi 84 pedestres/h.

Apesar de apresentar uma boa largura, que foi medida em 2,92 m, a quantidade de obstáculos existentes na calçada atrapalham o caminho do pedestre. São eles: buracos e depressões, saliências, bocas de lobo, raízes e copas de árvores, o próprio ponto de ônibus do local, ambulantes, lixos e dejetos, postes e placas de sinalização. A inclinação da calçada e a altura das guias estão corretas, mas o acabamento do piso e a altura das árvores pioram 
ainda mais o espaço.

Vale à pena ressaltar a existência de um muro que se estende por toda a calçada oposta à estação de trem. Com o muro, não há nenhum estabelecimento inclusive no trecho em questão, de modo que o único acesso possível é um edifício residencial localizado do outro lado da Av. Pe. José Maria. Destarte, o trecho fica praticamente isolado do principal movimento da via, o que acaba gerando a sensação de perigo e extremo desconforto para o pedestre. A grande predominância de vegetação no espaço disfarça essa sensação, principalmente aquela presente na calçada do trecho analisado e no canteiro central da via, que atinge agora 9,50m de largura.
Figuras 97-99: Av. Pe. José

Maria, na calçada oposta à Estação Santo Amaro (Trecho 2). Fonte: Acervo LABAUT.
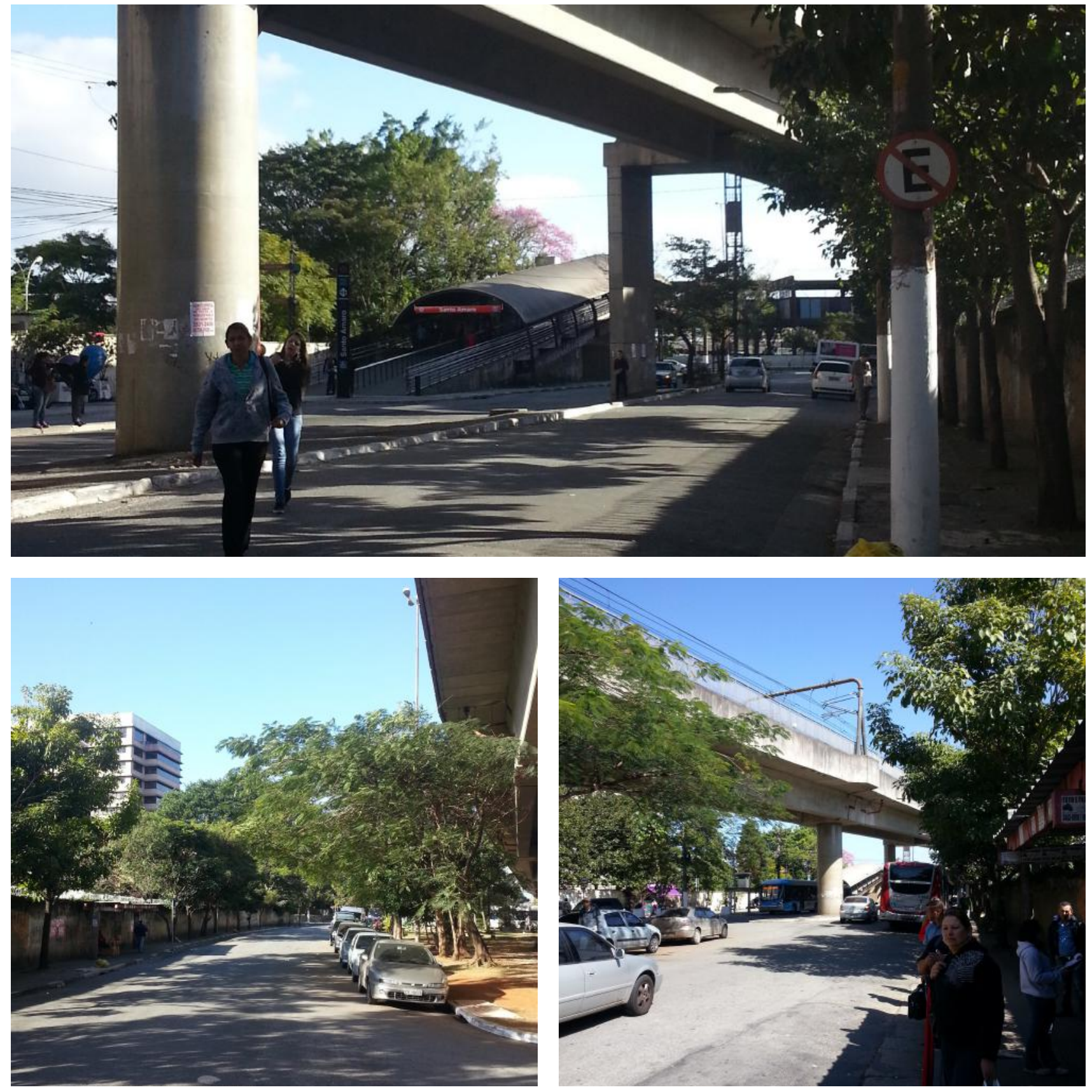


\section{ESTAÇÃO VILA SANTO AMARO DA CPTM}

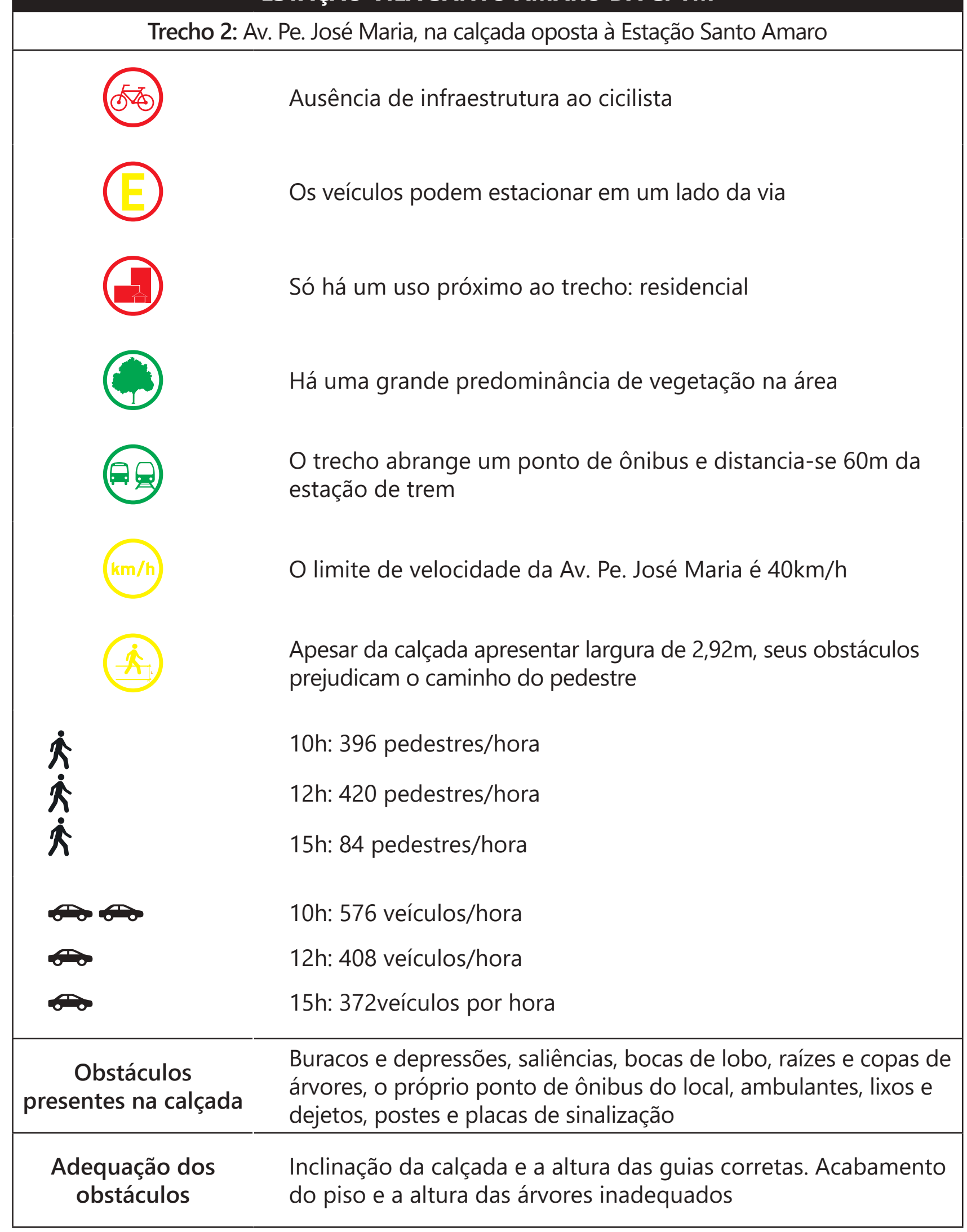

Tabela 50: Tabela síntese dos questionários aplicados no Trecho 2 da Estação Santo Amaro. Fonte: Elaborado pela autora. 


\section{Trecho 3: R. Engenheiro Francisco Pitta Brito, entre os $N^{\circ} 255$ e 425}

Estor ste trecho é bem distinto dos outros dos arredores da Estação Santo Amaro, razão pela qual foi escolhido. Situado na R. Engenheiro Francisco Pitta Brito, a quase $200 \mathrm{~m}$ da estação de trem e $150 \mathrm{~m}$ do ponto de ônibus mais próximo, o trajeto é marcado por casas, estabelecimentos comerciais e de serviços, constituindo uma paisagem urbana mais agradável e tranquila, com caráter de bairro residencial. Por uma questão de praticidade, o trecho abrange o primeiro quarteirão da R. Eng. F. Pitta Brito, entre o $N^{\circ} 255$ e N 425, que é o mais perto da Av. Pe. José Maria.

Não existem ciclovias ou ciclorrotas no local. Mesmo assim, o limite de velocidade de $30 \mathrm{~km} / \mathrm{h}$ da via oferece certa segurança aos ciclistas, que são diversas vezes vistos na área. Apesar de não ser abundante, a vegetação do trecho, presente nas calçadas e em alguns lotes, confere uma maior qualidade do ar e ameniza os ruídos do trânsito da Av. Pe. José Maria.

A partir da medição realizada às $10 \mathrm{~h}$, contou-se que passam 324 veículos em uma hora na R. Eng. F. Pitta Brito. Às 12h, foram contados 348 veículos/h e às 15h, o número aumentou para 588 veículos por hora. Deduz-se, dessa maneira, que o fluxo de veículos se eleva durante a tarde, mas que em geral não é intenso. O fluxo de pedestres no trecho também não se mostra relevante, e também aumenta no período vespertino: nas medições das 10h, $12 \mathrm{~h}$ e 15h, foram contabilizados 192, 432 e 396 pedestres por hora, respectivamente.

A implantação consecutiva de casas no trecho acaba limitando o estacionamento de veículos em um lado só da via, no qual não há tantas residências. Apesar de restringir o espaço dos automóveis no local, o inúmero acesso a garagens oferece certo risco de atropelamento para o pedestre. É interessante observar que, depois do trecho selecionado, os veículos já estacionam nos dois lados da via, uma vez que as construções ficam mais espaçadas umas das outras e os acessos às garagens são mais intervalados, abrindo espaço para estacionar o carro.

A largura das calçadas é razoável para a quantidade de pessoas no ambiente, apresentando 2,40m de um lado, e 2,42m de outro. Em compensação, nota -se que apresentam muitos obstáculos, como buracos e depressões, saliências e degraus, bocas de lobo, acessos a garagens, raízes e copas de árvores, canteiros de 
Figuras 100-102: R. plantas, orelhão, lixos e dejetos, postes e placas de sinalização. Engenheiro Francisco Pitta A inclinação da calçada e altura das guias estão corretas, mas Brito, entre os $\mathrm{N}^{\circ} 255$ e 425

(Trecho 3). Fonte: Acervo o acabamento do piso e a altura das árvores inadequados atrapalham ainda mais o caminho do pedestre.
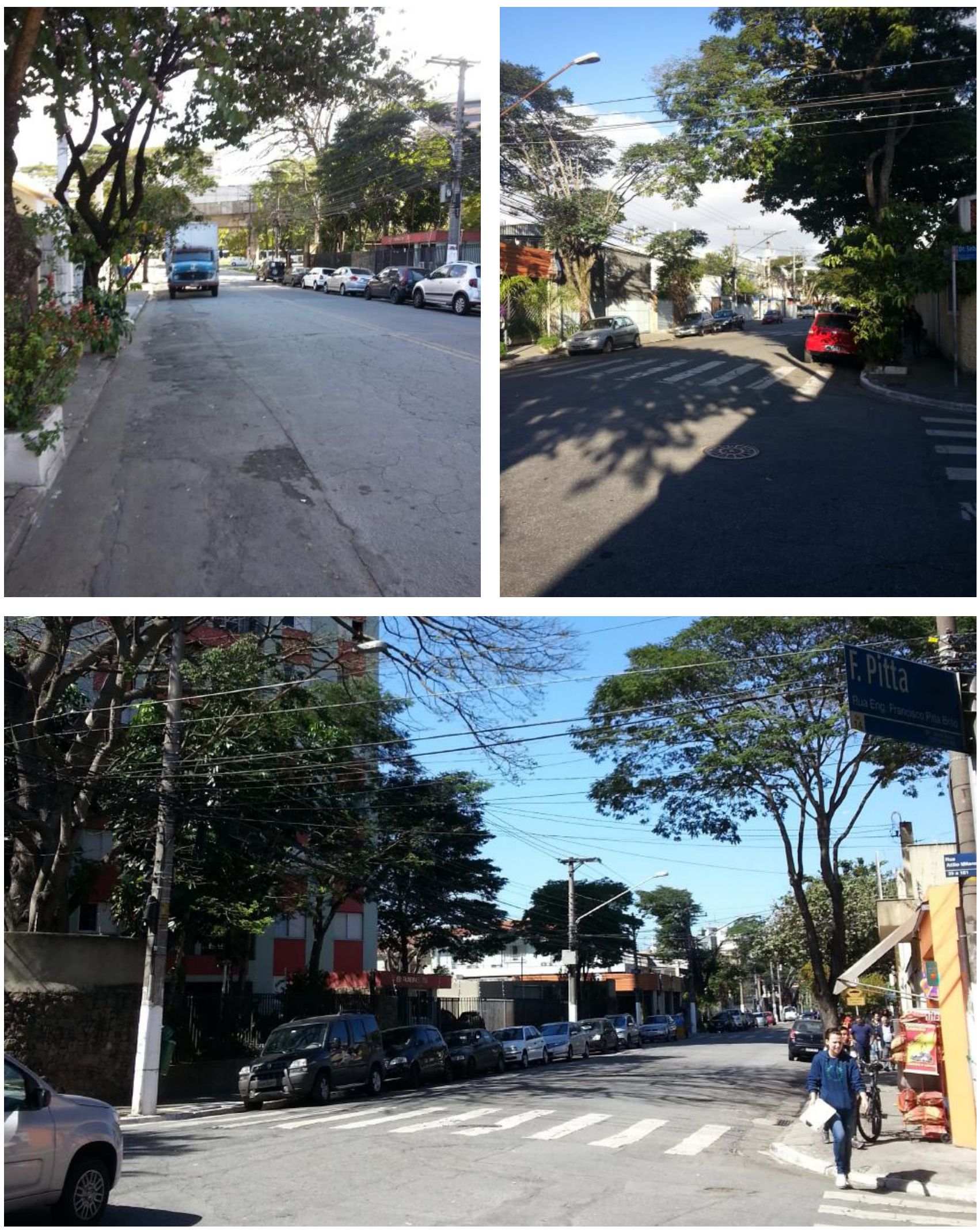

170 Capítulo 6: Aplicação do método de avaliação ergômica do ambiente urbano 


\section{ESTAÇÃO VILA SANTO AMARO DA CPTM}

Trecho 3: R. Engenheiro Francisco Pitta Brito, entre os $\mathrm{N}^{\circ} 255$ e 425
Os veículos podem estacionar em um lado da via
Há diversos usos do solo no trecho: residencial, comercial e de
serviços

Tabela 51: Tabela síntese dos questionários aplicados no Trecho 3 da Estação Santo Amaro. Fonte: Elaborado pela autora. 


\section{Percepção do usuário}

$\mathrm{O}$ bservando-se as perguntas da entrevista, verifica-se que as duas primeiras questões realizadas são abrangentes e se referem a percepção do ambiente e a beleza dos locais estudados. As questões subsequentes tratam de aspectos específicos, conforme se verá a seguir, que se relacionam diretamente com a percepção geral, fato que será discutido no item subsequente.

As questões 3 a 9 se referem aos aspectos ambientais que influenciam o cotidiano urbano, como qualidade do ar, nível de ruído, luminosidade, temperatura e umidade do ar, exposição ao sol e ao vento. Essas percepções são relacionadas, também no item subsequente, com as medições ambientais realizadas nos mesmos locais da aplicação das entrevistas, para verificar quais fatores alteram a percepção das pessoas acerca do ambiente.

As questões 10 e 11 se referem aos aspectos de segurança viária e segurança pública. As questões 12 a 14 se referem aos aspectos de percepção das calçadas e aos elementos de mobiliário urbano que as compõem. A questão 15 diz respeito à satisfação com relação à quantidade de vegetação existente no local em avaliação. As questões 16 e 17 avaliam a quantidade de assentos e lixeiras existentes.

Além das questões de percepção, os usuários foram sondados, na última questão acerca de quais serviços a região carece. Os serviços indicados foram: Bancos, Bares, Correios, Farmácia, Hospital, Lojas, Lotérica, Mercados, Padarias, Restaurantes e Local para carregar bilhete.

Algumas correlações das variáveis de percepção dos usuários com as medições de ergonomia e conforto urbano foram realizadas, como poderá ser observado a seguir.

A análise e discussão foram realizadas a partir do cruzamento dos dados coletados empiricamente em campo com as respostas das entrevistas de percepção do pedestre recém citadas. Assim, levam em consideração as medições ambientais e correlacionam com as respostas da pesquisa de percepção, em função do horário e do trecho de coleta de dados. A análise e discussão foi estruturada em três itens: "O caminhar e a calçada", "O entorno das 3 Estações" e "Percepção geral do pedestre".

A satisfação com determinada calçada éalgo variável e consequência 
de uma série de fatores subjetivos, mas que podem ser resumidos aqui com base nos resultados encontrados considerando as questões elaboradas neste estudo. Assim, os itens considerados foram: satisfação com a largura da calcada, satisfação com o piso da calcada, satisfação com a ausência de obstáculos, satisfação com a presença de bancos e lixeiras.

Este último item, com relação à presença de bancos ou lixeiras nas calçadas das regiões analisadas, é o fator que, segundo as respostas dos usuários, menos interfere na satisfação geral em relação ao passeio. Por outro lado, a largura das calcadas atingiu patamares de satisfação na casa dos setenta por cento, com pequenas variações ao longo do universo amostral. O que se nota é que a largura da calçada e um fator determinante para que o pedestre construa sua experiência no passeio. Isto significa que calçadas estreitas demais causam grande insatisfação. A avaliação em relação à dimensão das calçadas está diretamente relacionada com a quantidade de pedestres circulando, podendo variar bastante ao longo do dia, diferentemente de outros fatores, como a qualidade do piso e o número de obstáculos, que são fatores que não sofrem variação em curto espaço de tempo. Os fatores considerados mais importantes em um passeio, quando sua largura é considerada adequada pelos usuários, são o fluxo, a qualidade do piso e a ausência de obstáculos no trajeto (arvores, postes, vendedores ambulantes, bancas, pontos de ônibus, etc.). A regularidade na disposição dos obstáculos também foi citada nas entrevistas: árvores e postes alinhados e bem posicionados na faixa destinada a serviços da calcada ocasionam menor insatisfação. Quando se fala da qualidade do piso, deve se levar em conta, não só as peculiaridades do andar daqueles que apresentam dificuldades de locomoção, mas também a adequação do piso à presença de mulheres usando caçados de salto, pessoas carregando malas e outros objetos deslizantes, dentre outras situações comuns.

Na sequência, será considerada a questão da calçada em relação a outros aspectos ambientais no entorno de cada uma das 3 Estações em avaliação. Subsequentemente, será considerada ainda a questão das condições climáticas e a percepção ambiental como um todo.

No entorno da Estação Berrini, a satisfação dos pedestres quanto aos níveis de ruído é um fator bastante influenciado pelo fluxo de veículos, mas também pelo próprio fluxo de pedestres. As medições com sonômetro apontaram níveis de ruído bastante semelhantes nos trechos 1 e 2 - por volta de $70 \mathrm{~dB}(\mathrm{~A})$ às 9 e as $15 \mathrm{~h}$, e de $85 \mathrm{~dB}(\mathrm{~A})$ às $12 \mathrm{~h}$, valor já considerado proibitivo para exposição contínua. Embora o horário das $12 \mathrm{~h}$ tenha sido o de maior nível de ruído, foi o que apresentou a maior quantidade 
de usuários satisfeitos com o aspecto acústico, o que pode ter ocorrido pela diminuição do fluxo de veículos no trecho 2 nesse horário. A variação no fluxo de pedestres ao longo do dia teve resultados bastante perceptíveis na satisfação dos usuários quanto as calçadas. No trecho 1, a satisfação quanto a largura do passeio aumentou ao longo do dia, a medida em que o fluxo de pedestres diminuía. Nesse mesmo trecho, de forma geral, não houve muita variação na satisfação dos usuários conforme observado nas entrevistas realizadas às 9 e às 12 horas. No entanto, às 15 horas a satisfação com as calçadas foi muito superior, inclusive quanto a fatores que independem do fluxo e não variam ao longo do dia, como a qualidade do piso e a presença de bancos e lixeiras. Essa divergência pode ter sido ocasionada pela diferença entre o perfil dos usuários que circulam pelo local ao longo do dia. De manhã e ao meio-dia, a maior parte das pessoas que passavam pelo local trabalham na região. Já às 15 horas, havia uma quantidade maior de usuários que declaravam passar por lá esporadicamente, não percebendo alguns problemas ou não os julgando ruins. No trecho 3 a satisfação com a calçada foi menor às 12 horas, horário de maior fluxo de pedestres. A insegurança relacionada ao risco de atropelamento foi maior no trecho 2, o qual apresentou os maiores fluxos de veículos, principalmente nos horários das 9 e das 15 horas. Nos demais trechos, os pedestres não se sentiram tão inseguros, provavelmente porque os fluxos de veículos e a velocidade máxima permitida na via são menores.

No entorno da Estação Vila Olímpia, os fluxos de pedestres variaram muito ao longo do dia, diferentemente dos de veículos. Tanto no trecho 1, quanto no trecho 2, a satisfação dos entrevistados com a largura da calcada foi menor às 9 horas, quando muitas pessoas saiam da estação de trem, do que no restante do dia. A percepção sobre o risco de atropelamento acompanhou as variações no fluxo de pedestres ao longo do dia na saída da estação da Av. Marginal Pinheiros: nos horários em que havia menos pedestres na calçada, a percepção sobre o risco de atropelamentos foi menor, aumentando no horário de fluxo mais intenso. A diversidade das dinâmicas de usos dos três trechos analisados acarreta diferentes percepções em relação às calçadas, tanto em relação às diferenças físicas quanto ao fluxo de pedestres. Os dois primeiros trechos se diferem do terceiro por serem locais quase exclusivamente de passagem, utilizados pelos usuários que desembarcam do trem, enquanto a Rua Funchal apresenta mais usos e atrativos para os pedestres, havendo mais relação entre o ambiente construído e a calçada. A percepção dos usuários sobre o ruído e a qualidade do ar variaram pouco ao longo do dia, possivelmente devido ao fluxo de veículos não variar muito ao longo do dia. 
No entorno da Estação Santo Amaro, assim como no entorno da Estação Vila Olímpia, notou-se uma acentuada diferença entre as calçadas dos trechos 1 e 2 em relação às do trecho 3. As calçadas dos dois primeiros trechos se configuram como espaços de passagem, nos quais a maior parte dos usuários apenas transita para chegar a outros locais ou apenas espera pelo transporte coletivo em um ponto de ônibus após a saída da estação de trem. Não há muitos acessos a edificações nem muito contato com as atividades desenvolvidas no interior dos lotes, o que pode, inclusive, ter causado uma sensação de insegurança nos entrevistados, que se mostraram, no geral, descontentes com o risco de assaltos, apesar de os fluxos mostrarem que havia uma quantidade significativa de pedestres nesses locais. Outro diferencial dos dois primeiros trechos é que dificilmente o uso desses espaços se dá por um período prolongado, sobretudo nos horários de grande fluxo, nos quais o tempo de espera pelo transporte público é reduzido. No trecho 2, a satisfação com o nível de ruído não apresentou muita variação nas entrevistas realizadas às 9 e às 12 horas: por volta de $50 \%$ dos entrevistados estavam satisfeitos. No entanto, às 15 horas apenas cerca de $10 \%$ dos entrevistados estavam satisfeitos, embora os níveis de ruído não tenham sofrido grandes alterações ao longo do dia de acordo com as medições de acústica realizadas. Essa diferença pode estar relacionada ao fato de o período de permanência dos entrevistados no local, no geral, haver sido maior no último horário, uma vez que, com uma demanda menor, o tempo de espera nos pontos de ônibus são maiores. Assim, apesar de a intensidade do ruído não variar muito ao longo do dia, um maior tempo de exposição causou um maior descontentamento por parte dos usuários. No entanto, deve-se considerar, também, que o perfil dos usuários que frequentam o local varia ao longo do dia, sendo que pela manhã havia mais usuários que trabalhavam na região, frequentando-a diariamente. Essa diferença também pode ter influenciado o baixo índice de satisfação dos entrevistados quanto à largura da calçada no mesmo trecho. O menor número de entrevistados satisfeitos com esse quesito foi obtido às 15 horas, horário em que o fluxo de pedestres é muito menor do que o medido pela manhã e ao meio-dia, e que, portanto, esperava-se que a largura da calçada não fosse um problema aos usuários.

O estudo realizado verificou que os fatores relacionados ao risco de atropelamento e de assalto têm pouca influência no julgamento geral da via. Poucas vezes os pedestres denotaram medo de atropelamento, salvo em ruas de pequeno porte onde são obrigados a trafegar pelo leito carroçável. O medo de assalto, por sua vez, também não apresentou relevância na pesquisa, provavelmente por praticamente todos os pontos analisados estarem localizados em corredores de grande fluxo e as medições 
terem sido feitas no período diurno. Questões relacionadas tanto a carência de luminosidade quanto ao ofuscamento, iluminação ou contraste excessivos não foram levantados pelos pedestres em quase nenhum momento. Apesar de não ser dos fatores mais importantes na opinião dos pedestres, satisfação com a presença de áreas verdes e diretamente proporcional a satisfação com a via e cresce junto com esta. Em termos efetivos há um baixo contentamento em relação a qualidade do ar, mas em geral, as pessoas se colocam em uma posição de maior conformidade frente a este aspecto, resultando em baixo impacto na satisfação geral com a via, assim como acontece no caso do ruído urbano, ao qual o pedestre também parece demonstrar conformidade, não refletindo na satisfação geral com a via.

A satisfação do pedestre com a calcada, apesar de ter influência na avaliação da via como um todo pelo pedestre, não é o fator de maior relevância. Há uma leve correspondência entre a satisfação com a caçada e a satisfação com a via, porém, em geral, o índice de satisfação geral do usuário com a via como um todo é maior que o conforto especificamente com a calçada. Quando a satisfação com as calçadas é menor é também menor a satisfação em relação à via. Quando a satisfação com as calçadas é maior, há outros fatores importantes que caracterizam a qualidade de uma via. Ou seja, até certo ponto, as calçadas devem ter propriedades (largura e qualidade piso) que sustentem o fluxo adequado para aquela via. Se não for atingido este mínimo, a insatisfação com a calçada é determinante no desconforto que o pedestre sente na via. Porém, uma vez supridas estas condições, o que realmente leva à satisfação com a via está ligado a outros fatores. Neste contexto, os fatores físicos de maior relevância na apreensão da qualidade de uma via por parte do pedestre são a beleza percebida e qualidade de seus edifícios lindeiros. Quando questionados sobre a qualidade e a satisfação que sentem com a via, são poucos aqueles que fazem uma análise mais técnica, falando de questões como a largura das calçadas, adequação do porte e posicionamento de vegetação e/ ou edifícios, etc.

Por outro lado, o estudo realizado mostrou que a satisfação geral de um usuário com a via é fortemente relacionada ao conforto térmico. No geral, a partir de $18^{\circ} \mathrm{C}$ de temperatura do ar, há uma maior coincidência entre conforto térmico e satisfação geral com a via, ambos atingindo seu pico em torno de $22^{\circ} \mathrm{C}$ ( $90 \%$ de conforto térmico e $85 \%$ de satisfação geral) e, depois disso, há uma queda na satisfação com relação direta ao aumento da temperatura. Foi ainda registrada uma clara tendência de aumento no conforto dos pedestres com o aumento da incidência solar nos períodos mais frios e com a diminuição da incidência solar nos períodos 
mais quentes, conforme era de se esperar. O mesmo não foi verificado para a ação dos ventos, aos quais a satisfação não parece estar intrinsicamente ligada simplesmente ao seu poder de arrefecimento, mas também a preferência de estar ou não submetido à ação deste. Essas observações mostram que o fator ambiental de maior peso para a compreensão da questão do conforto térmico do pedestre é a radiação térmica. Não apenas a radiação solar direta, mas também suas parcelas indiretas. Isto significa que para uma via ser satisfatória, além de proporcionar sombra ou acesso ao sol, deve apresentar também soluções de controle a radiação indireta, como a refletida de elementos como fachadas ou do próprio pavimento.

Assim, deve-se ressaltar que o conforto térmico depende das variáveis ambientais temperatura do ar, umidade do ar, velocidade do ar e radiação térmica. Considerando a sensação térmica propiciada pela ação conjunta das quatro variáveis, quando a temperatura equivalente percebida (TEP), ou temperatura de sensação, atinge 20 oC, o conforto térmico se torna o fator mais decisivo para a composição da satisfação geral de um pedestre. A partir de TEP $=340 C$, a satisfação térmica e a satisfação geral decaem exponencialmente à medida em que cresce o desconforto em função da sensação de calor. Os valores de TEP que geram maior conforto térmico e maior sensação de satisfação geral estão na faixa de $210 \mathrm{C}$ a $240 \mathrm{oC}$, porém entre $240 \mathrm{oC}$ e $340 \mathrm{o}$ há ainda forte correlação entre ambos os critérios. 


\section{Discussão dos resultados obtidos}

São tecidas aqui as conclusões. A satisfação geral (Questão 1) dos pedestres, em relação ao local onde caminham, guarda alguma relação com a fruição estética do mesmo (Questão 2). Apesar de alguma insatisfação com a qualidade do ar (Questão 3) e com os níveis de ruído (Questão 4), estes fatores não se relacionam com a satisfação geral dos pedestres. Conforme argumentado, isto talvez se deva ao fato da poluição e do ruído terem se tornado intrínsecos ao cotidiano dos moradores de grandes metrópoles, porém, devese atentar para as questões de saúde relacionada a estes dois fatores. A quantidade de luz (Questão 5) não gerou insatisfação específica ou relação com a satisfação geral do pedestre. Ressaltase que o estudo foi realizado apenas em período diurno. O conforto térmico (Questões de 6 a 9: temperatura, umidade, sol e vento) apresentou variações no grau de satisfação de suas questões que variaram com alta correlação com a satisfação geral do pedestre, chegando ao ponto de determinar esta em algumas situações. O risco de atropelamento (Questão 10) mostrou-se presente em situações em que a calçada não se mostrava suficiente para o fluxo de pedestres e o risco de assalto (Questão 11) foi muito pouco mencionado. Contudo, não apresentaram relação com o grau de satisfação geral do pedestre. Com relação à calçada (Questão 12) esta deve comportar adequadamente o fluxo de pedestres (Questão 13) e apresentar qualidade mínima de piso (Questão 14) caso contrário irá determinar insatisfação geral do pedestre. Por outro lado, aspectos positivos relacionados a ela não influenciam positivamente na satisfação geral do pedestre. A presença de vegetação (Questão 15), locais para sentar (Questão 16), lixeiras (Questão 17) e existência de serviços (Questão 18), apesar de influenciarem em pequeno grau em termos de satisfação e insatisfação específicos não influenciam na satisfação geral do pedestre.

Em suma, segundo a percepção dos pedestres entrevistados, o local do caminhar deve comportar o fluxo de pessoas e deve propiciar condições de piso para tanto. Suprida essa necessidade, são as condições de conforto térmico que determinarão em grande medida a satisfação geral com o local.

É importante salientar que diversas variáveis influenciam na percepção do pedestre, sendo o recorte desta pesquisa ainda restrito. A percepção do pedestre é obviamente muito maior do que 
se consegue traduzir por meio de dezoito perguntas objetivas. As entrevistas realizadas não abarcaram diretamente fatores culturais e psicológicos, apesar de pressupor e subentender-se que estes são contemplados nas entrevistas indiretamente. $O$ espaço urbano é muito mais complexo do que o descrito por variáveis físicas e ambientais.

Considerando-se um contexto metropolitano em que se realizam diariamente grande número de longos deslocamentos, este estudo voltou-se para uma nova centralidade de serviços e negócios, focando-se nos deslocamentos a pé realizados antes ou depois da utilização do sistema da Companhia Paulista de Trens Metropolitanos. Focando-se no ato de caminhar, buscou-severificar a qualidade dos espaços urbanos com base no levantamento de variáveis ambientais relacionadas a características ergonômicas e de conforto ambiental, e na realização de entrevistas acerca da percepção ambiental dos pedestres.

Algumas relações entre a percepção do pedestre e a etapa quantitativa, como também com a percepção do ambiente, da calçada e do entorno evidenciam a necessidade de não utilizar métodos meramente quantitativos para a análise do ambiente urbano.

O método aqui proposto é um ponto de partida para um exercício conjunto entre a ergonomia, o conforto e a cidade.

Contudo, por meio de todos esses recortes, buscou-se discutir a importância do caminhar na metrópole não pensada para caminhar. Buscou-se, em meio ao conformismo com relação à poluição do ar e ao ruído urbano, em meio à simplista identificação do desconforto térmico em tempos de mudanças climáticas tão divulgadas, em meio ao ato de caminhar infelizmente restrito a uma calçada, questionar a saúde dos pedestres e dos espaços urbanos. 


\section{Quadro resumo}

- A avaliação realizada no Safári (pré-teste) foi técnica, oriunda principalmente de equipamentos de laboratório e, portanto, seus resultados foram mais quantitativos.

- A seleção das três estações na área do entorno da Berrini se deu, além do fato da importância em termos de usuários do sistema de transportes coletivo, também devido ao fato da possibilidade de verificar as condições espaciais e ambientais no entorno dessas estações, entendendo e valorizando a mobilidade das pessoas no ato de caminhar e na percepção.

- O método proposto para a avaliação ergonômica do ambiente urbano, é constituído por duas partes: uma avaliação dos aspectos físicos do ambiente (quantitativa) e uma avaliação da percepção dos usuários sobre o espaço (qualitativa).

- Para cada estação definiram-se trechos que foram avaliados dentro do método exposto no capítulo anterior.

- A satisfação com determinada calçada é algo variável e consequência de uma série de fatores subjetivos, mas que podem ser resumidos aqui com base nos resultados encontrados considerando as questões elaboradas neste estudo. Assim, os itens considerados foram: satisfação com a largura da calcada, satisfação com o piso da calcada, satisfação com a ausência de obstáculos, satisfação com a presença de bancos e lixeiras.

- A satisfação geral (questão 1) dos pedestres, em relação ao local onde caminham, guarda alguma relação com a fruição estética do mesmo (questão 2).

- O risco de atropelamento (questão 10) mostrou-se presente em situações em que a calçada não se mostrava suficiente para o fluxo de pedestres e o risco de assalto (questão 11) foi muito pouco mencionado.

- Segundo a percepção dos pedestres entrevistados, o local do caminhar deve comportar o fluxo de pessoas e deve propiciar condições de piso para tanto. Suprida essa necessidade, são as condições de conforto térmico que determinarão em grande medida a satisfação geral com o local.

- Algumas relações entre a percepção do pedestre e a etapa quantitativa, como também com a percepção do ambiente, da calçada e do entorno evidenciam a necessidade de não utilizar métodos meramente quantitativos para a análise do ambiente urbano.

- O método aqui proposto é um ponto de partida para um exercício conjunto entre a ergonomia, o conforto e a cidade. 
Este trabalho apresentou a proposta de método de avaliação Eergonômica para o ambiente urbano, no qual a ergonomia possui um caráter de integração com o conforto ambiental.

A hipótese que a ergonomia pode ser entendida de forma mais abrangente e integrada com os elementos estruturadores: físico, ambiental, psicológico e cultural foi verificada através da proposição do método de avaliação ergonômica para o ambiente urbano.

O método apresentado e aferido na tese apresenta duas partes distintas: uma etapa quantitativa, na qual avaliou-se os aspectos físicos e ambientais do ambiente urbano em questão, e uma etapa qualitativa, que avaliou a percepção do espaço nas esferas do ambiente, da calçada e do entorno.

$\mathrm{Na}$ parte quantitativa, além dos aspectos relacionados com as questões ergonômicas, houve a verificação das questões relacionadas com o conforto térmico, acústico e luminoso, com o objetivo principal de integrá-las em um mesmo contexto. A análise da percepção do usuário, através da escala qualitativa de satisfação do pedestre fez a ponte entre a etapa quantitativa e a qualitativa.

As relações encontradas entre os valores avaliados na primeira etapa e a percepção do usuário, mostra a importância desta análise conjunta, uma vez que a primeira etapa isolada não contempla uma efetiva avaliação do espaço.

Desta maneira, a proposta de entendimento da ergonomia de uma forma mais ampla, contempla a integração com as variáveis de conforto ambiental, além de incorporar, os aspectos culturais e psicológicos do ambiente avaliado, mesmo que de forma indireta, confirmando a hipótese da tese.

Apesar da existência de métodos de conforto ambiental amplamente consolidados nas áreas de conforto térmico, acústico e luminoso, na área de ergonomia, observa-se uma grande quantidade de métodos em fase de amadurecimento.

Assumindo a necessidade de integrar a ergonomia e o conforto ambiental para a sua utilização nos processos de projeto e nas avaliações do ambiente urbano, a proposta de método aqui apresentada assumiu para a ergonomia os quatro fatores 
estruturadores: físico, ambiental, psicológico e cultural, com o propósito de reforçar o seu caráter integrador e ir além dos aspectos meramente de dimensão física.

Todas as áreas que fazem parte do conforto ambiental, térmica, acústica, iluminação natural e artificial, e ergonomia devem ser avaliadas em conjunto, dentro de um contexto que adequem todas as possíveis interfaces com o projeto procurando estabelecer a relação destas áreas e o comportamento do usuário.

A ergonomia, juntamente com o conforto ambiental, com o seu caráter integrador deve ser resgatado no processo de projeto, e nas análises de desempenho ambiental, não só para auxiliar um resultado mais adequado, mas também para auxiliar na transformação necessária de edifícios e de cidades em ambientes de melhor desempenho e qualidade ambiental.

No contexto do ambiente as avaliações que integrem as variáveis de ergonomia e de conforto ambiental têm o objetivo de melhorar o desempenho do espaço avaliado tendo como resultado ambientes melhores e mais saudáveis.

O conforto ambiental trabalha com a relação da Ergonomia e - Meio através das sensações e estímulos, é desejável que este processo de avaliação traga a possibilidade de interação dos fatores físicos, ambientais, psicológicos e culturais.

Um dos aspectos mais essenciais no processo da avaliação da ergonomia, do conforto ambiental e a percepção espacial é a compreensão de como os indivíduos percebem, assimilam e agem a partir de informações que captam no ambiente à sua volta.

No caso do ambiente urbano, partiu-se do pressuposto que a dimensão humana foi desconsiderada por décadas no projeto e no planejamento das cidades, em detrimento a questões que ganharam (e ainda ganham) importância e força, como por exemplo, a adaptação das cidades ao aumento do tráfego de automóveis. O espaço reduzido, o ruído, a poluição, o risco de acidentes, os obstáculos, os assaltos, entre outros, são fatores comuns na maioria das grandes cidades da atualidade, fazem com que os pedestres não consigam efetuar uma atividade primordial, que não os diferem por gênero, faixa etária ou etnia: exercer ato de caminhar.

Ao relacionar a Ergonomia com morfologia urbana física, podese analisar o espaço diante de uma visão que envolve não só a identificação do gabarito urbano, mas também a identificação de obstáculos fixos, obstáculos móveis e de questões de conforto ambiental e segurança humana. 
Os pressupostos de construção do método aqui apresentado permitiram que este fosse construído. As aplicações dos métodos de referência permitiram a identificação de lacunas e a possibilidade de revisão de aspectos pontuais da proposta aqui apresentada.

A contribuição aqui deixada objetiva o exercício conjunto da ergonomia, do conforto ambiental e do projeto, e desta forma, a proposta não é fechada nem circunscrita em si mesma. A proposta visa auxiliar nas necessárias mudanças de paradigmas dos usuários além melhorar a qualidade do ambiente urbano. 


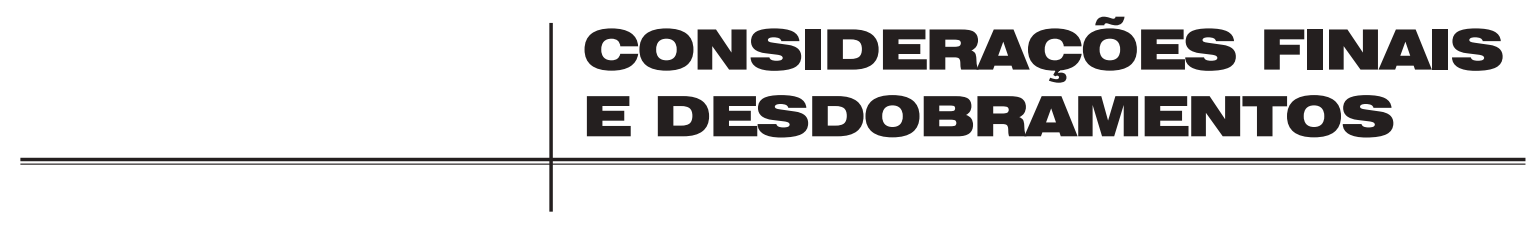

Esta tese apresentou uma proposta de método de avaliação para Eo ambiente urbano. Como continuidade e desdobramento deste método a sua aplicação para o edifício já está sendo verificada em pesquisas que se encontram em andamento.

O cenário mostrado no segundo capítulo desta tese, reforça a necessidade de busca de novos referenciais para a ergonomia e o conforto ambiental.

A partir da contextualização, não só do cenário atual global de necessidade de redução dos impactos ambientais, mas também da necessidade de incorporação mais efetiva das avaliações de ergonomia e conforto ambiental, procurou-se mostrar a importância de aproximar o projeto, a ergonomia e o conforto ambiental.

A partir de uma visão geral da evolução e dos diferentes enfoques dados ao conforto ambiental, no decorrer da história de nas diferentes áreas do conhecimento, chega-se nos edifícios atuais, nos quais a eficiência energética passa a ser imperativa e passa-se a exigir um envolvimento mais proativo entre ocupante, edifício e ambiente.

O conforto adaptativo surge em cena, coloca a atenção no "comportamento do usuário", ressalta a necessidade de convidar o usuário a ser proativo e a buscar dentro das suas exigências, o conforto ambiental desejado, além de gerar economia de energia e até maior qualidade ambiental. Esta noção de conforto adaptativo foge à tradicional concepção de algo a ser oferecido por determinado ambiente, mas sim se tornando algo a ser alcançado pelo usuário.

O principal pressuposto do conforto adaptativo consiste no fato que os ocupantes dos edifícios têm o potencial de se ajustar e encontrar as suas condições de conforto por meio de mudanças individuais de roupas, atividades, posturas, localização, ajustes de condições do ambiente (aberturas de janelas e portas, ajustes de persianas e/ou proteções solares, acionamento de ventiladores).

Além deste vínculo com os ajustes fisiológicos e comportamentais, estas oportunidades de adaptação ligadas ao modelo do conforto adaptativo, estão estreitamente ligadas a uma grande mudança cultural relacionada com a forma como os ambientes são utilizados e controlados, nos quais variações climáticas são não só esperadas, 
mas principalmente desejadas.

Este contexto vem ao encontro das proposições da tese, reforça os pressupostos aqui apresentado, e deve ser incorporado nesta abordagem sugerida para a "nova ergonomia" nas avaliações do ambiente construído.

Vale a pena observar, que o processo de requalificação dos edifícios existentes deve passar por um momento de reflexão sobre o patrimônio edificado já existente, e formas de inseri-lo no cenário de recuperação da habitação no centro da cidade, não só pelas modificações tecnológicas, funcionais e estéticas, mas também pelas possíveis maneiras de se apropriar novamente do espaço público.

Também é importante salientar que será necessária uma mudança de consciência e de comportamento nas atitudes e práticas diárias, tanto dos usuários do ambiente construído quanto dos órgãos políticos de decisão e investidores, a fim de implementar uma mudança real de paradigma que proporcione conforto ambiental, em níveis superiores aos encontrados hoje em ambientes com maior eficiência energética e mais saudáveis.

Apesar do ensino de Conforto Ambiental ter tido um expressivo impulso devido ao contexto mundial global de necessidade de redução dos impactos ambientais, a sua concepção em disciplinas estanques ainda prejudica o entendimento de seu objeto de estudo na espacialidade do projeto. A abordagem convencional das variáveis de conforto no projeto, na maioria das vezes, aprofunda o detalhamento dos aspectos relacionados com os fatores físicos, em detrimento aos aspectos sócio culturais, psicológicos e ambientais.

Na FAUUSP, junto às disciplinas de conforto ambiental, a inserção do projeto no processo de aprendizagem dos alunos mostrou-se uma ferramenta eficaz, não só por coloca-los diante de problemas reais, vivenciados no seu cotidiano em uma escola de arquitetura, mas também por mostrar a importância da avaliação das questões de ergonomia e de conforto ambiental desde a fase preliminar do projeto. Propositalmente, o objeto de estudo dos alunos do primeiro ano tem sido o edifício e entorno da FAUUSP.

O processo de levantamento do ambiente e da percepção do usuário levou-os a considerar, não só as variáveis físicas e ambientais, mas também as variáveis culturais e psicológicas tendo em vista que muitas vezes as contradições entre as variáveis medidas e os dados obtidos nas inquirições (questionários, entrevistas e observações) eram gritantes. 
Além desta sensibilização com as questões de Conforto Ambiental, o "olhar" para o edifício da FAUUSP também promove a articulação entre o objetivo didático fundamental da escola - o ensino de boas práticas de concepção, elaboração e construção de obras arquitetônicas e de intervenções urbanísticas - e as intervenções destinadas à manutenção, adequação e ampliação de edifícios e espaços de interesse patrimonial.

Este encadeamento leva os alunos a olharem criticamente os levantamentos e a priorizarem em seus diagnósticos as suas principais diretrizes de projeto para as demandas verificadas.

Estas experiências de ensino também os têm levado a constatar a importância da inserção da ergonomia e do conforto ambiental no processo de projeto, com possibilidade de atingir ações mais efetivas independentemente do processo de projeto escolhido.

É imperativo que as questões relacionadas à ergonomia e ao conforto ambiental façam parte das práticas de projeto deste 0 início das discussões relacionadas ao partido inicial, bem como todas as inter-relações que possam ocorrer com estes fatores.

A ergonomia e o conforto ambiental devem ser avaliados em conjunto, dentro de um contexto que adequem todas as possíveis interfaces com o projeto procurando estabelecer a relação destas áreas e o comportamento do usuário. Sem esta busca, as questões relacionadas ao conforto ambiental tendem, na maioria dos casos, a ficarem isoladas, sem conexão com o processo de projeto, apenas cumprindo um protocolo dentro do projeto como um todo.

Apesar de um longo caminho a percorrer, estas ações são necessárias para conseguirmos edifícios e um ambiente urbano de maior qualidade.

Neste contexto a Ergonomia, com o seu caráter integrador deve ser resgatado no processo de projeto, e nas análises de desempenho ambiental, não só para atingir um resultado adequado, mas também como instrumento de projeto, com todos os seus fatores integradores, para a transformação necessária de edifícios e de cidades em ambientes de melhor desempenho e qualidade ambiental. 
ABNT, NBR 9050 - Acessibilidade a edificações, mobiliário, espaços e equipamentos urbanos. ABNT 2015.

ABRAHÃO, J; PINHO, D.; SARMET, M.; SILVINO, A.; SZNELWAR, L. (2009) Introdução à Ergonomia - da prática à teoria. Blücher, São Paulo.

ACKERMANN, M. E. (2002). Cool Comfort: America's romance with air conditioning. Washington, Smithsonian Institution Press.

BELTRAME, M. B; Moura, G. R. S. Edificações escolares: infraestrutura necessária ao processo de ensino e aprendizagem escolar. [s.d]. Disponível em: http://www.unioeste.br/prppg/ mestrados/letras/revistas/travessias/ed_006/EDUCAÇÃO/PDF/ EDIFICAÇÕESESCOLARES.pdf. Acesso 8 de maio de 2016.

BURDETT, R.; SUDIC, D. (Editores) (2007). The Endless City. London: Phaidon. lorque.

. (2013) Active Design: Shaping the sidewalk experience. Nova

CARERI, Francesco (2013). Walkscapes- O caminhar como prática estética. São Paulo: Gustavo Gili, $2^{\mathrm{a}}$ ed.

CARUNCHIO, C. F. Avaliação de desempenho, sob o enfoque ergonômico, das funções e atividades da habitação com caráter social: os espaços internos e externos. FAU USP, 2015. Iniciação científica.

CARVALHO, Marcus V. S. de A (2006). Um Modelo para Dimensionamento de Calçadas Considerando o Nível de Satisfação do Pedestre. Tese de doutorado apresentada à Escola de Engenharia de São Carlos da Universidade de São Paulo. São Carlos.

CAVALCANTE, Sylvia; Nóbrega, Lana Mara Andrade (2011) Espaço e lugar IN Sylvia Cavalcante e Gleice Azambuja Elali (Eds.) Temas básicos em psicologia ambiental. Editora Vozes. Rio de Janeiro.

CAVALCANTE, Sylvia; Elias, Terezinha Façanha (2011) Apropriação. IN Sylvia Cavalcante e Gleice Azambuja Elali (Eds.) Temas básicos em psicologia ambiental. Editora Vozes. Rio de Janeiro.

CHAPPELLS H; SHOVE E. (2004). Comfort: a review of philosophies and paradigms. Lancaster University, Reino Unido. (www.lancaster. ac.uk/fass/projects/.../fc_litfinal1.pdf) 
CHENG, Vicky \& Steemers, Koen.(2010). Perception of urban density, IN Mostafavi, Mohsen and Doherty, Gareth (ed.) Ecological urbanism. Baden: Lars Muller Publisher, pp.476-482.

CHENG, Vicky Bo-Ki (2010). Human perception of urban density. 2010. Dissertation for the degree of Doctor of Philosophy. Wolfson College - University of Cambridge, Cambridge.

CHURCHMAN, Arza (1999) Disentangling the Concept of Density. Journal of Planning Literature 13, 4: 389-411.

CHURCHMAN, Arza (2002). Environmental Psychology and Urban Planning: Where Can the Twain Meet? IN R. B. Bechtel and A. Churchman (ed.) Handbook of Environmental Psychology. John Wiley \& Sons, Inc. Chapter 12, pp. 191-200.

CIDADE DE NOVA IORQUE (2013) (1). Active Design Guidelines: promoting physical activity and health in design. Nova lorque.

(2013) (2): Active Design: Shaping the sidewalk experience 1. Nova lorque.

sidewalk experience 2. Nova lorque.

(2013) (3): Active Design: Shaping the CORBUSIER, Le (2004). Por uma arquitetura. $6^{\text {a }}$ edição, editora Perspectiva.

COSTA, Ana Paula Lima e VILLAROUCO (2014) - Que metodologia usar? Um estudo comparativo de três avaliações ergonômicas em ambientes construídos, in Um novo olhar para o Projeto - a ergonomia no ambiente construído, Editora UFPE.

CINTRA, M (2014) Os custos dos congestionamentos na cidade de São Paulo. Textos para Discussão. FGV Sao Paulo School of Economics.

CPTM (2015) Linha Esmeralda Disponível em http://www.cptm. sp.gov.br/linhas/linha9. Acesso em: 23 de dezembro de 2015.

DAMACENO, Daliana; GALVES, Maria Lucia; OLIVEIRA, Gil de; VIOLATO, Rafaella Ribeiro; Non-morotized Mobility in Central Urban Areas: Application of Multi-Criteria Decision Aid in the city of Campinas, Brazil.

DRURY, Colin G (2008); Human Factors in Industrial Systems: 40 years on in Human Factors: The Journal of the Human Factors and Ergonomics Society, Golden Anniversary Special Issue, vol 50, issue 03. SAGE Publishing.

DANIELLOU, F. (org.) (2004) - A ergonomia em busca de seus princípios - debates epistemológicos. São Paulo, Blücher.

EMMANUEL, M. Rohinton; An Urban Approach to Climate-Sensitive Design -Strategies for the Tropics; cap. 6: Climate-sensitive urban 
transportation for the tropics; Ed. Spon Press; New York, 2005

EVANS, M. (1980). Housing, Climate and Comfort. London, The Architectural Press.

FONSECA, Juliane Figueiredo (2004) A contribuição da ergonomia ambiental na composição cromática dos ambientes construídos de locais de trabalho de escritório. Tese de mestrado do Programa de Pós-Graduação em Design do Departamento de Artes e Design. Pontifícia Universidade Católica do Rio de Janeiro.

FROTA, Anésia B.; SCHIFFER, Sueli B. Manual de conforto térmico. São Paulo: Nobel, 1995.

FRUGOLI JUNIOR, H. (2000) Centralidade em São Paulo: trajetórias, conflitos e negociações na cidade. São Paulo, Edusp.

GLAESER, E. L. (2011) Triumph of the City: How Our Greatest Invention Makes Us Richer, Smarter, Greener, Healthier, and Happier. Penguin, 2011.

GEHL, Jan (2014) Cidades para Pessoas, Perspectiva, São Paulo, $2^{\text {a }}$ edição.

GIFFORD, Robert (1997). Environmental Psychology: Principles and Practice. Ally and Bacon.2nd edition, ch.7, p.139-170, ch.11, p.241275.

GIFFORD, Robert (2002). Making a difference: some ways environmental psychology has improved the world. IN Bechtel, Robert \& Churchman, Arza (eds.) Handbook of Environmental Psychology. John Wiley \& Sons, Inc. Chapter 21.P. 323-334.

GRANDJEAN, Etienne. Manual de Ergonomia. Porto Alegre: Bookman, 1998.

GONÇALVES, Joana C. et al (2015) - O Edifício Ambiental, São Paulo, Oficina de Textos.

HALL, Edward Twitchell (2005). A dimensão oculta. Editora Martins Fontes. São Paulo.

HIGHWAY CAPACITY MANUAL (2000) - Transportation Research Board. Nacional Research Council, Washington.

IBGE. (2014) Banco de Dados Agregados. Disponível em: <http:// www.sidra.ibge.gov.br/>. Acesso em: 16/11/2014.

INSTITUTO DE DESENVOLVIMENTO DE POLÍTICAS DE TRANSPORTE (ITDP). Índice de Caminhabilidade - ferramenta. Rio de Janeiro, 2016.

ITTELSON, W.H., PROSHANSKY, H.M., RIVLIN, L.G. (1970). The use of behavioral maps in environmental psychology. In Proshansky, H.M., Ittelson, W.H., Rivlin, L.G. (Eds.). Environmental Psychology: Man and His Physical Setting, pp. 658-668. New York: Holt, Rinehart \& 
Winston.

ISO 7726. Ergonomics of the thermal environment: instruments for measuring physical quantities. Genève: ISO, 1998.

ITTELSON, W. H., PROSHANSKY, H. M., RIVLIN, L. G., \& WINKEL, G. $H$. (1974). An introduction to environmental psychology. New York: Holt, Rinehart and Winston.

JACOBS, Jane (2009). Morte e Vida de Grandes Cidades; São Paulo: Martins Fontes.

KENWORTHY, Jeffrey R.; The Eco-City: Ten Key TransportAnd Planning Dimensions For Sustainable City Development; in Environment and Urbanization 2006

KOWALTOWSKI, Doris, C.C.K., (2011) Moreira, Daniel et. al. (orgs) O processo de projeto em arquitetura da teoria à tecnologia, São Paulo. Oficina de Textos.

KRONKA MÜLFARTH, R. C. (2015) - A reocupação de edifícios multifamiliares no centro de São Paulo, uma reflexão sobre a questão ergonômica. In O Edifício Ambiental, São Paulo, Oficina de Textos.

KRONKA MÜLFARTH R.C. e MONTEIRO, L. M. (2014) - Diagnóstico Ambiental de espaços urbanos para desenvolvimento de projetos de microacessibilidade no entorno do Rio Pinheiros. Relatório de Pesquisa LABAUT.

KRONKA MÜLFARTH, R. C. (2013) Sustentabilidade e Mobilidade: o desenho urbano $e$ as questões relacionadas com a qualidade ambiental. IV SIMPGEU - Simpósio de Pós-Graduação em Engenharia Urbana e I ENURB - Encontro Nacional de Tecnologia Urbana.

KUHNEN, Ariane (2011) Percepção ambiental IN Sylvia Cavalcante e Gleice Azambuja Elali (Eds.) Temas básicos em psicologia ambiental. Editora Vozes. Rio de Janeiro.

LEE, Terence (1976) Psicologia e Meio Ambiente. Zahar Editores.

LERNER, Jaime (2013) Prólogo à Edição Brasileira de Jaime Lerner, In: Cidades para Pessoas, Gehl, Perspectiva, São Paulo, $2^{a}$ edição.

LYNCH, Kevin (2008). La imagen de la ciudad. Barcelona: Gustavo Gili.

HALL, Eduard (2005) - A dimensão oculta - São Paulo, Martins Fontes.

HARRIS, Sabrina; (2015) Estrutura Espacial Urbana e Mobilidade: o Caso da Região Metropolitana de São Paulo, Dissertação de Mestrado, FAUUSP, São Paulo.

MALATESTA, Maria Ermelina B.(2007) Andar a pé: Um modo de transporte para a cidade de São Paulo. Dissertação de Mestrado, 
FAUUSP, São Paulo.

MEYER, R.M.P; GROSTEIN, M.D; BIDERMAN, (2004) C. São Paulo Metrópole, São Paulo, EDUSP Imprensa Oficial.

MONTEIRO, L. M. (2015) - Conforto Ambiental e as possibilidades do modelo adaptativo, in O Edifício Ambiental, São Paulo, Oficina de Textos.

MONTEIRO, L. M.; ALUCCI, M. P. (2009). An outdoor thermal comfort index for the subtropics. Proceedings of 26th Passive and Low Energy Architecture. Quebec: PLEA.

MONTEIRO, L. M. e ALUCCI, M. P. (2005). Outdoor thermal comfort: numerical modelling approaches and new perspectives. Proceedings of 22nd Passive and Low Energy Architecture. Lebanon: PLEA.

MORAES, A; MONT'ALVÃO, C. (2003) - Ergonomia: Conceitos e Aplicações. Rio de Janeiro: 2AB Editora.

NABIL, A; MARDAJEVIC, J. - Useful daylight illuminances: A replacement fr daylight factors; Energy and Buildings 38, Elsevier 2006.

NAKAMURA, Meire Mayumi; Desenho Urbano - Mobilidade e Acessibilidade; Trabalho Final de Graduação, FAU USP, 2012.

NAKAMURA M; e KRONKA MÜLFARTH, R. C. Mobilidade e Acessibilidade no Desenho Urbano com Qualidade Ambiental. In: IV Encontro Nacional de Ergonomia do Ambiente Construído e V Seminário Brasileiro de Acessibilidade Integral, Florianópolis. IV Encontro Nacional de Ergonomia do Ambiente Construído e V Seminário Brasileiro de Acessibilidade Integral, 2013.

OLIVEIRA PEDRO, J. A. C. B. de - Definição e Avaliação da Qualidade Arquitetônica Habitacional, Tese de Doutorado, Universidade do Porto - Lisboa, 2000.

Organização das Nações Unidas - ONU (2014); World Urbanization Prospects, Nova lorque.

ORNSTEIN, S. W. (2004) Divergências metodológicas e de resultados nos estudos voltados às relações ambiente-comportamento (RAC) realizados nas escolas brasileiras de arquitetura. IN E. T. de O. Tassara, E. P. Rabinovich e M. do C. Guedes (Eds) Psicologia e Ambiente. Educ.

PINHEIRO, José Q. (2004) O lugar e o papel da psicologia ambiental no estudo das questões humano-ambientais, segundo grupos de pesquisa brasileiros. IN E. T. de O. Tassara, E. P. Rabinovich e M. do C. Guedes (Eds.) Psicologia e Ambiente. Educ.

PINHEIRO, José Q.; Elali, Gleice Azambuja (2011) Comportamento sócio espacial humano IN Sylvia Cavalcante e Gleice Azambuja Elali 
(eds) Temas básicos em psicologia ambiental. Editora Vozes. Rio de Janeiro.

PORTAS, N. - Funções e Exigências de Áreas da Habitação - Lisboa, MOP - Laboratório Nacional de Engenharia Civil, 1969.

POZUETA, Julio; Movilidad Y Planeamiento Sostenible: Hacia una consideración inteligente del transporte y la movilidad en el planeamiento y en el diseño urbano; in Cuadernos de Investigación Urbanística, Madrid, 2005

PREISER, Wolfgang F. E.; RABINOVITZ, Harvey Z. e WHITE, Edward R. (2015) - Post-Occupancy Evaluation. Routledge, Francis \& Taylor, Nova lorque.

PREISER, Wolfgang F. E.; e VISCHER, Jacqueline C. (2005) - Assessing Building Performance. Elsevier, Oxford.

PRINS, G. (1992). "On condis and coolth." Energy and Buildings 18: 251-258.

PROGRAMA DAS NAÇÕES UNIDAS PARA OS ASSENTAMENTOS HUMANOS (ONU- HABITAT) 2015. Diretrizes Internacionais para Planejamento Urbano e Territorial. Nairóbi.

QUEIROGA, Eugênio F. (2014). Da relevância pública dos espaços livres - um estudo sobre metrópoles e capitais brasileiras. In: Rev. Inst. Estud. Bras., São Paulo, n. 58, p. 105-132.

NOSDO - Ayuntamiento de Sevilla, Urbanismo; Plan Especial de Indicadores de Sostenibilidad Ambiental de la Actividad Urbanística de Sevilla; cap3.: "Indicadores relacionados con la movilidad y los servicios".

ORNSTEIN, S.; BRUNA, G. e ROMERO, M. A. (1995) - "Ambiente Construído \& Comportamento". Nobel, São Paulo.

RAPOPORT, A. (1975) Toward a redefinition of density. Environment and Behavior. Sage Publications Inc.

RAPOPORT, A. (1976). The Mutual Interaction of People and their Built Environment: a cross-cultural perspective. The Hague, Mouton and Co.

RAPOPORT, A. (1978). Aspectos humanos de la forma urbana: Hacia una confrontación de las Ciencias Sociales con el diseño de la forma urbana. Barcelona. Gustavo Gili.

RODE, P.; FLOATER, G (2014). Accessibility in cities: transport and urban form. Londres: LSE Cities, v. 3.

ROLNIK, R; KLINTONWITZ, D. (2011) (I)mobilidade na cidade de São Paulo. Estudos Avançados 25 (71).

ROLNIK, R. (1999) A cidade e a lei: legislação, política urbana e territórios na cidade de São Paulo. São Paulo, SP: Studio Nobel/ 
Fapesp.

ROMERO, Marcelo de Andrade (1997). Arquitetura, Comportamento e Energia. FAUUSP, Tese de livre-docência.

SEADE (2014). Projeção da População para 2030. Disponível em: <http://produtos.seade.gov.br/produtos/projpop/index.php>. Acesso em: 16/11/2014.

SEO, He Nem Kim. A requalificação no Glicério. São Paulo, 2009 (Trabalho Final de Graduação apresentado à Faculdade de Arquitetura e Urbanismo da Universidade de São Paulo).

SCHMID, Aloísio Leoni (2005) A idéia de conforto: reflexões sobre o ambiente construido. Curitiba: Pacto Ambiental.

SOUTHWORTH, Michael (2005) - Designing the Walkable City; in Journal Of Urban Planning And Development (C) Asce.

SPECK, Jeff (2016). Cidade Caminhável. São Paulo, Perspectiva.

UNEP - United Nations Environmental Programme (2011) Buildings investing Energy and Resource Efficiency. The Green Economy Report. Disponível em www.unep.org/greeneconomy (acesso em dezembro 2015).

VIANNA JUNIOR, Edison Vieira. Passeios, Calçadas e Infra-estruturas para o Tráfego de Pedestres em São Paulo. São Paulo, 2000 (Tese de mestrado apresentada à Faculdade de Arquitetura e Urbanismo da Universidade de São Paulo).

VIANNA, N. S. (2002) - O estado da arte em ensino e pesquisa na área de conforto ambiental no Brasil. Universidade do Grande $A B C$, Santo André, SP.

VILLAROUCO, Vilma, 2002. Avaliação ergonômica do projeto arquitetônico. $12^{\circ}$ Congresso Brasileiro de Ergonomia. Anais. Recife: ABERGO.

VIRILIO, Paul (1993). O Espaço Crítico. Rio de Janeiro: Editora 34.

WISNER, A. (2004) Questões epistemológicas em ergonomia e em análise do trabalho in A ergonomia em busca de seus princípios debates epistemológicos. São Paulo, Blücher.

WASHBURN, Alexandros (2013) - "Nature of Urban Design - A New York Perspective on Resilience", Island Press, Washington.

ZUMTHOR, Peter (2009) Atmosferas: entornos arquitetônicos - as coisas que me rodeiam. Editora Gustavo Gili. Barcelona, Espanha. 

